DEPARTAMENTO DE MICROBIOLOGÍA Y GENÉTICA

UNIVERSIDAD DE SALAMANCA / CSIC

Instituto de Biología Funcional y Genómica

\title{
Interacción de las rutas PKC y RIM101 en el mantenimiento de la integridad celular
} de Saccharomyces cerevisiae

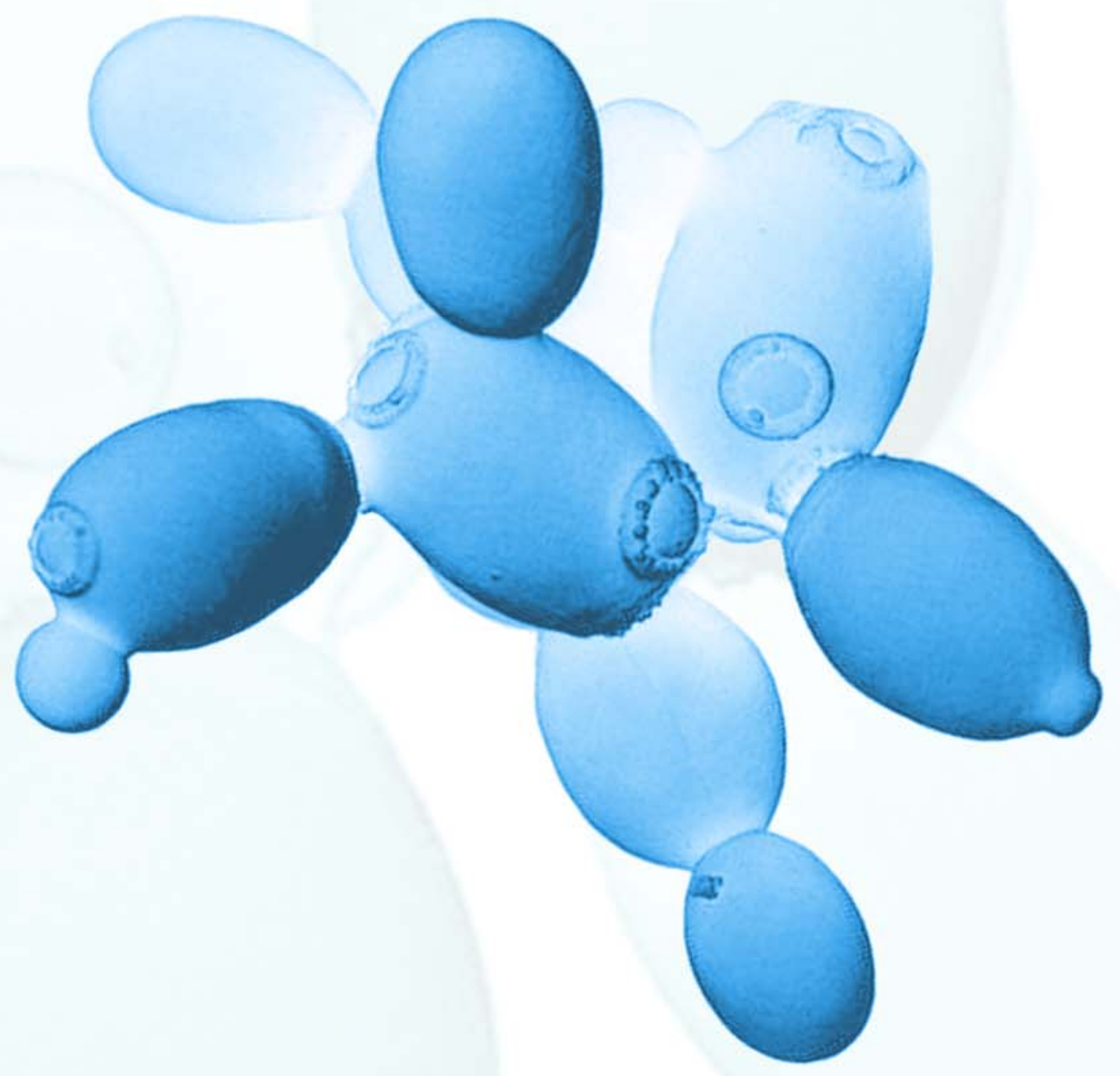

ALBERTO GÓMEZ SANZ

Salamanca 2011 

Departamento de Microbiología y Genética Instituto de Biología Funcional y Genómica (USAL/CSIC)

Interacción de las rutas PKC y RIM101 en el mantenimiento de la integridad celular de Saccharomyces cerevisiae

Alberto Gómez Sanz

Salamanca 2011 



\section{UNIVERSIDAD DE SALAMANCA}

Departamento de Microbiología y Genética Instituto de Biología Funcional y Genómica (USAL/CSIC)

Interacción de las rutas PKC y RIM101 en el mantenimiento de la integridad celular de Saccharomyces cerevisiae

Memoria presentada por Alberto Gómez Sanz para optar al grado de Doctor en Ciencias Biológicas 

DEPARTAMENTO DE

D. CÉSAR RONCERO MAílLO, PROFESOR TITULAR del DEPARTAMENTO DE MICROBIOLOGÍA Y GENÉTICA de la UNIVERSIDAD DE SALAMANCA,

\section{CERTIFICA:}

Que el licenciado Alberto Gómez Sanz ha realizado el trabajo titulado "Interacción de las rutas PKC y RIM101 en el mantenimiento de la integridad celular de Saccharomyces cerevisiae" bajo mi dirección, en el Instituto de Biología Funcional y Genómica (IBFG), centro mixto de la Universidad de Salamanca (Departamento de Microbiología y Genética) y del Consejo Superior de Investigaciones Científicas (CSIC), para optar al grado de Doctor en Ciencias Biológicas.

Y para autorizar su presentación y evaluación por el tribunal correspondiente, expide el presente certificado en Salamanca, a 1 de Junio de 2011.

Dr. César Roncero Maíllo 

DEPARTAMENTO DE

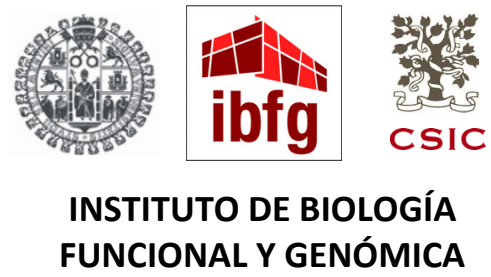

D. ÁNGEL DOMÍNGUEZ OLAVARRI, CATEDRÁtICO de MICROBIOLOGÍA y DIRECTOR del DEPARTAMENTO DE MICROBIOLOGÍA Y GENÉTICA de la UNIVERSIDAD DE SALAMANCA,

\section{CERTIFICA:}

Que la memoria titulada "Interacción de las rutas PKC y RIM101 en el mantenimiento de la integridad celular de Saccharomyces cerevisiae", presentada por el licenciado Alberto Gómez Sanz para optar al grado de Doctor en Ciencias Biológicas, ha sido realizado bajo la dirección del Dr. César Roncero Maíllo, en el Instituto de Biología Funcional y Genómica (IBFG), centro mixto de la Universidad de Salamanca (Departamento de Microbiología y Genética) y del Consejo Superior de Investigaciones Científicas (CSIC).

Y para autorizar su presentación y evaluación por el tribunal correspondiente, expide el presente certificado en Salamanca, a 1 de Junio de 2011.

Dr. Ángel Domínguez Olavarri 

Parece mentira, pero la aventura en la que me embarqué hace ya bastantes años llega a su fin. jEl día T ha llegado! Me gustaría dedicarle estas líneas a todas las personas que han compartido conmigo este camino, haciendo la elaboración de esta Tesis más llevadera gracias a su trabajo o, simplemente, con su compañía.

En primer lugar, quiero agradecer al Dr. César Roncero por haberme dado la oportunidad de formar parte de su grupo, dirigir este trabajo y así permitirme conocer de primera mano el día a día en un laboratorio.

Al Director del IBFG, el Dr. Ángel Durán, y a todo el personal administrativo y técnico del Departamento y del IBFG: Miguel, Paco Soriano, Paco Alonso, Manolo, Encarna y el resto de personal de cocina, Carmen, Alberto, Alegría, Laura y Javier, cuyo trabajo hace que todo resulte más fácil. Al Servicio de Microscopía Electrónica de la Universidad y a Carlos Belinchón, por su ayuda y consejos en la preparación de las muestras.

Al Dr. Charlie Boone y a todo su grupo, principalmente a Nydia, gracias a los cuales me decidí a cruzar el charco y pude comprobar cómo se trabaja en otros laboratorios.

Estos años no hubieran sido lo mismo sin toda la gente que ha pasado por el 219222. A Charo, mil gracias por tu cariño "serrano" y por estar hasta el último minuto dispuesta a echarme un cable, poniéndome las pilas cuando tocaba. A Cris, gracias por tus múltiples consejos y por permitirme ser tu padawan. Jaqui, tu llegada supuso todo un gran apoyo para mí. Abi, gran predecesora... isigo tus pasos! Carlitos, digno becario junior, ya sabes lo que toca... ja ser feliz! Y a José Ángel, Javi, Mariona, Junior, Belén, Ribas e Ivone, ha sido todo un placer compartir laboratorio, buenos ratos y risas con vosotros.

A todos los compañeros del grupo de Pared y del IBFG por vuestra disposición para resolver las dudas cotidianas, pero ante todo por hacer que el ambiente de trabajo en el centro fuera mucho más ameno. Especialmente a Cris, Espe, Laura Andrés, Marisa, Belinda, Toñi, Sergio Rincón, Mario, Javi Encinar, Laurita, Anita y Rebe, por haber tenido siempre palabras de ánimo para mí y por echarme una mano cuando lo necesitaba.

A María, David, Mariajo, María y Ángel, porque son ya muchos años a vuestro lado y nada sería lo mismo sin vosotros. A Aida, Carlos, Lau, María Gallega, Mer, Mon, Sara, Vico y Xiana, ya que vuestra compañía ha sido imprescindible para poder disfrutar los grandes momentos y sobrellevar mejor los no tan buenos. Al resto de Biólogos, especialmente a 
Cris, David, Omar, Patri, Irene, Inés, María, Jacob, Manu, María Rizos y Rosa, porque ya han pasado 11 años desde que nos conocimos, y a pesar de que nuestros caminos se hayan separado bastante, seguimos disfrutando en cada reencuentro. A Baghee, Furby, Luismi, María, Susu y Zaida, por esas magníficas veladas y porque, aunque nunca comprendierais realmente a qué me dedicaba, me aceptasteis igualmente.

Al Club de fans de John Boy: Lorena, Carlitos, Sofía, José Ángel, Patri, Raúl y Miguel, por esos cafés y esas "córeos" en el Tum-Tum, que no serían lo mismo sin vosotros. A Anna, cuya vida científica nació de forma casi simultánea a la mía. iÁnimo, todo llega! A Talía, mi compañera de fatigas. ¡Ya somos Doctores! A Nuna, por tu capacidad para robarme una carcajada, iso payasa! ...¿̇y ahora qué??? A LaUruguasha, María y Andrés, porque nunca es tarde para dar con gente como vosotros. A Lorena, Vero, Juan, Isa y Oli, ya que durante este tiempo no han faltado nuestras citas "trimestrales" en compañía de unos pinchos o unas tartas. A todos los "Rogelios" (Laurita, Marta, Elena, José Luis, Mercedes, Dani, Eva...) por hacerme sentir como uno de los vuestros en los múltiples eventos a los que me invitasteis. A Laura, que hiciste mi estancia en Toronto mucho más agradable. A Ana, Teté y Lucía, gracias por esas risas tan necesarias alrededor de unas cañas. A Marta, porque siempre encontramos un hueco para ponernos al día tomando un café. A Guille, por tu "morning elegance" y tu espléndida tontuna. A todos los que han hecho de los miércoles una jornada más agradable en farmacia (Javi, Andrea...).

A Lau, Mon, Talía, Esther, Javi y Naza... porque estos últimos meses de biblioteca han sido mucho más llevaderos gracias a vuestros consejos y compañía. A Cris, Lau, María, Charo, Antonio, Guille, Jaqui y Carlitos, por vuestras críticas constructivas y por ayudarme sin rechistar en la elaboración de esta memoria (correcciones, encuadernación, portada...).

Y especialmente me gustaría agradecer a toda mi familia, sobre todo a mis padres, por darme libertad para permitirme elegir mi camino y poder contar con vuestro apoyo en todo momento, y porque sin duda alguna, todo lo que he llegado a ser os lo debo a vosotros. Y a los pequeños de la casa, por la alegría y energía que me transmitís. 


\section{ABREVIATURAS}

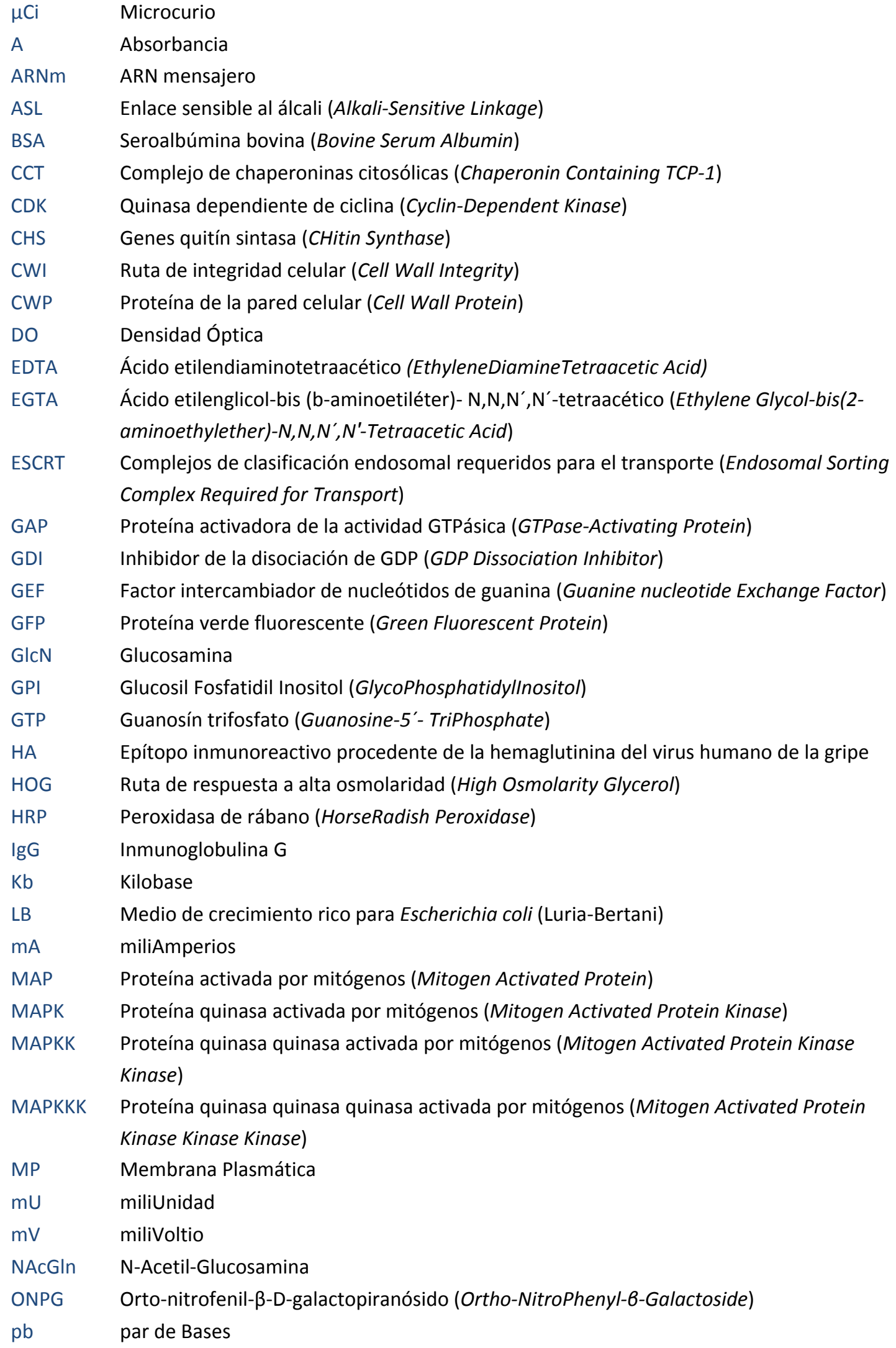




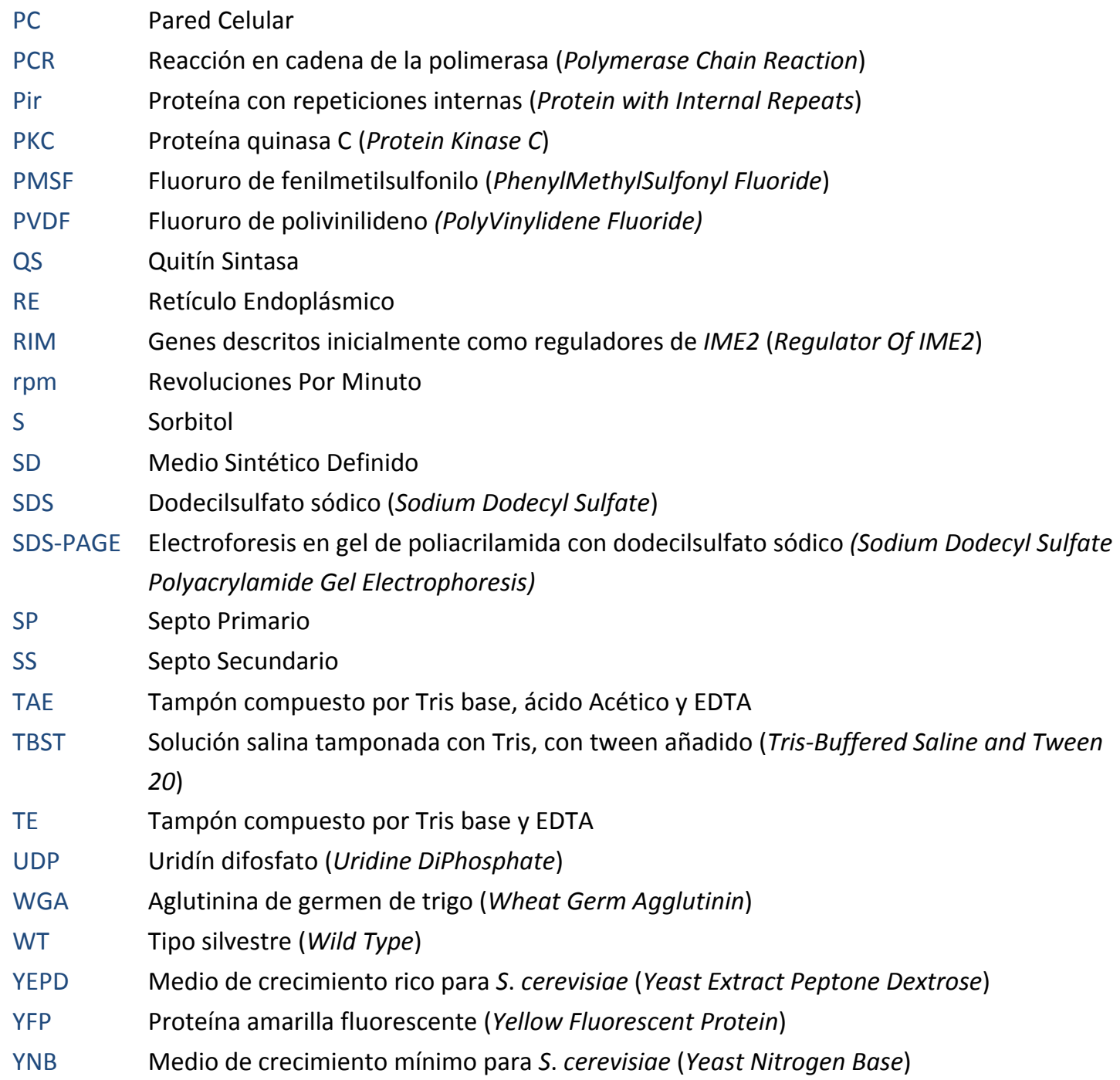




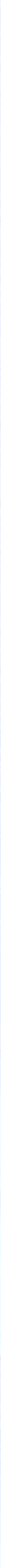



1 CICLO DE VIDA Y MORFOGÉNESIS...................................................................

2 LA PARED CELULAR FÚNGICA .....................................................................11

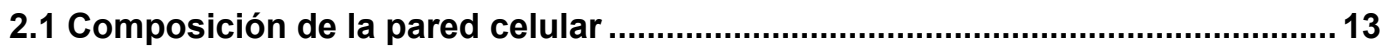

2.2 Estructura molecular de la pared celular ....................................................... 13

2.3 Biosíntesis de los compuestos de la pared celular ......................................... 14

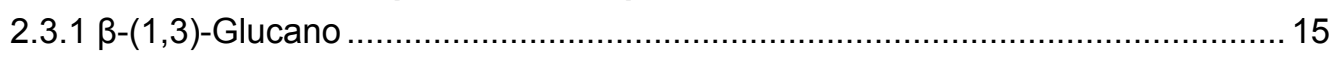

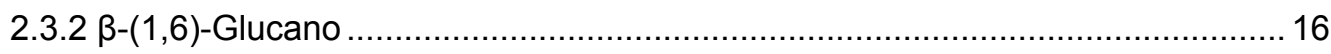

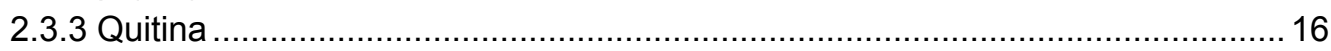

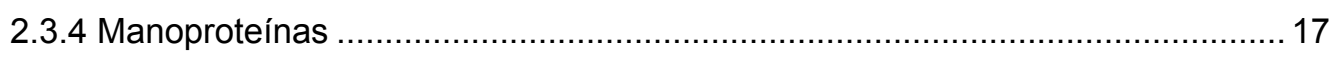

2.4 Dinámica y remodelación de la pared celular ................................................. 17

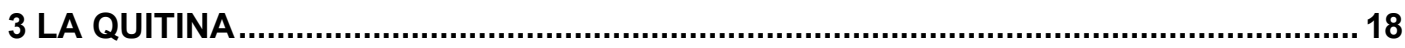

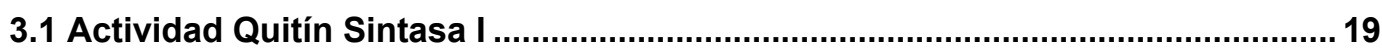

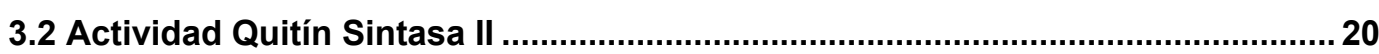

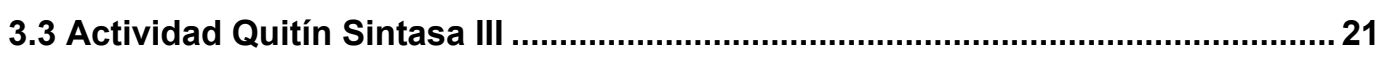

3.3.1 Características generales ....................................................................... 21

3.3.2 Función y regulación de la actividad QSIII y caracterización de los genes

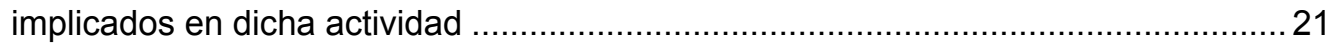

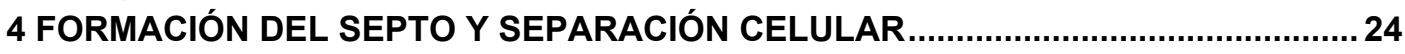

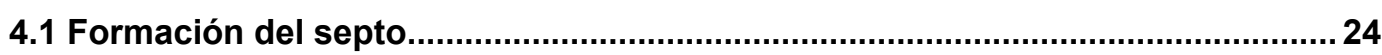

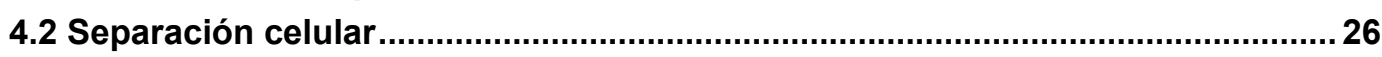

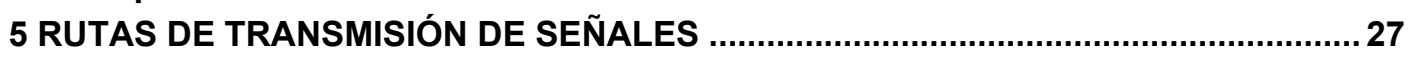

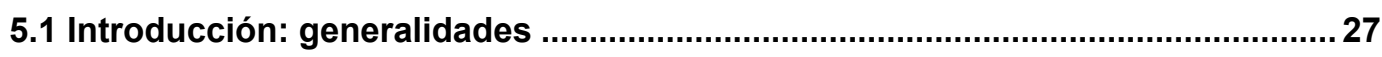

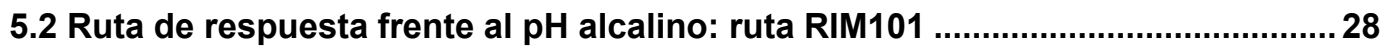

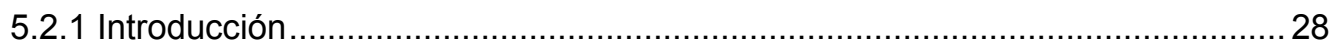

5.2.2 Ruta RIM101 de S. cerevisiae: activación y componentes................................ 30

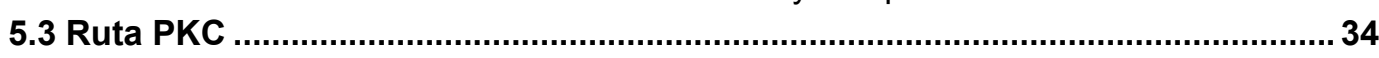

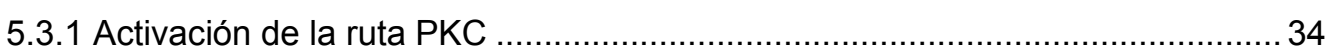

5.3.2 Los componentes de la ruta PKC y su función en la respuesta ........................ 37

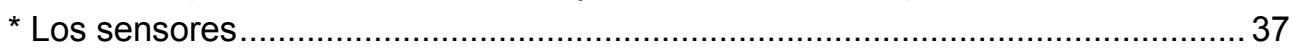

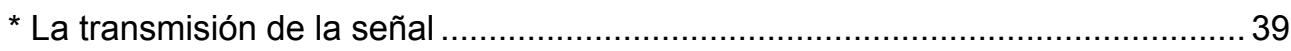

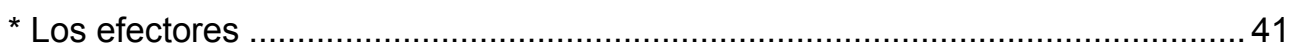

Objetivos $\quad 43$

Materiales y Métodos $\quad 47$

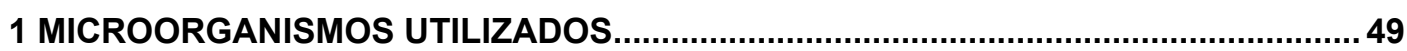

2 MEDIOS Y CONDICIONES DE CULTIVO …........................................................5 50

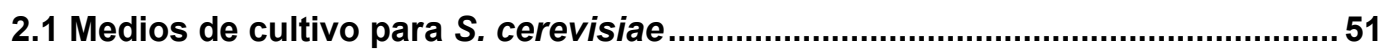

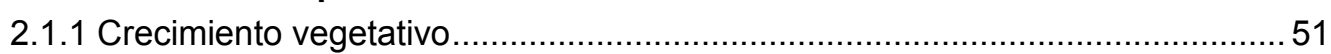

2.1.2 Medios de selección de resistencia a antibióticos ............................................ 52

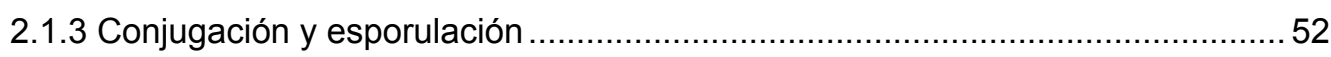


2.1.4 Medios suplementados con otros compuestos para ensayos de resistenciasensibilidad.

2.2 Condiciones de crecimiento para S. cerevisiae ...............................................54

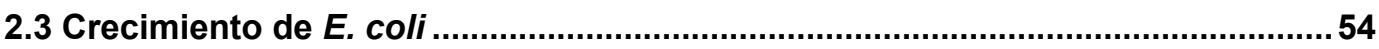

3 TÉCNICAS GENERALES DE BIOLOGÍA MOLECULAR ........................................55

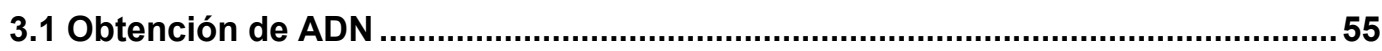

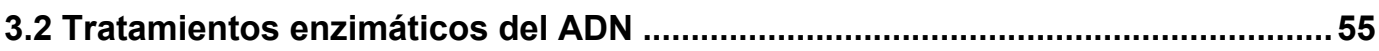

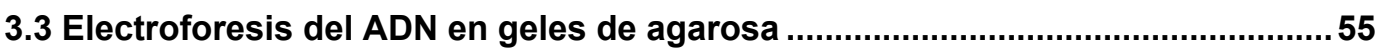

3.4 Reacción en cadena de la polimerasa (PCR) ....................................................56

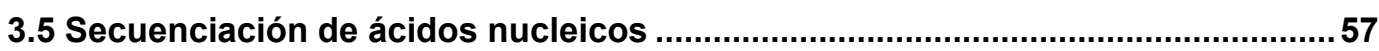

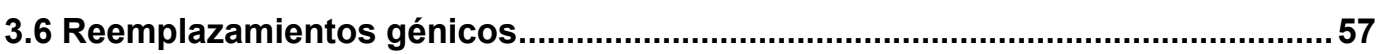

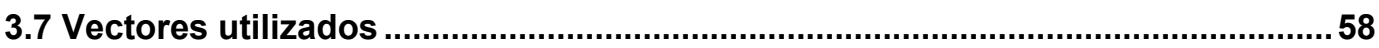

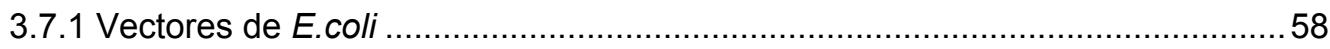

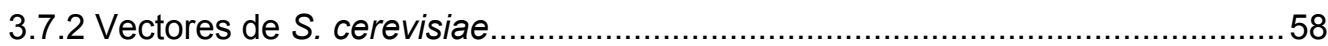

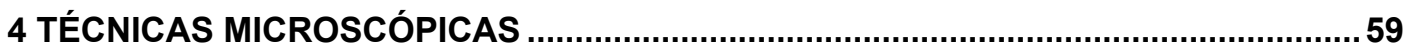

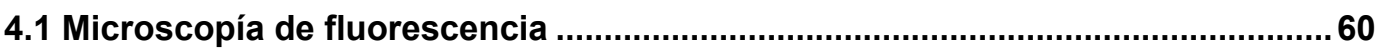

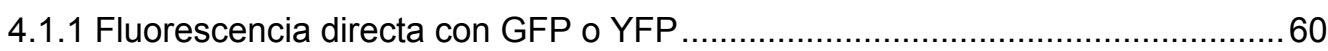

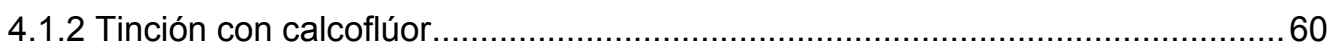

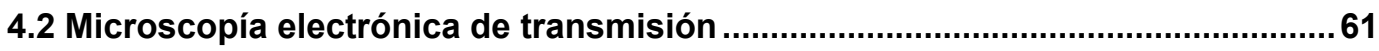

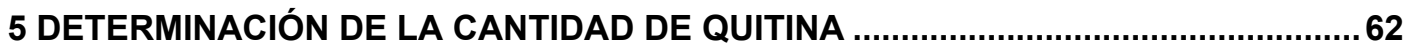

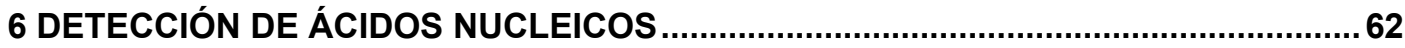

6.1 Preparación de sondas marcadas radiactivamente .............................................62

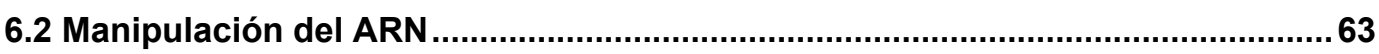

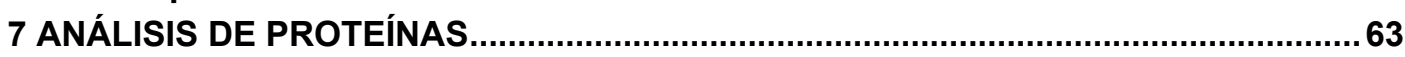

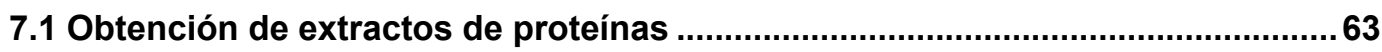

7.2 Separación electroforética e inmunodetección......................................................64

8 ENSAYO $\beta$-GALACTOSIDASA CUANTITATIVO …..................................................6

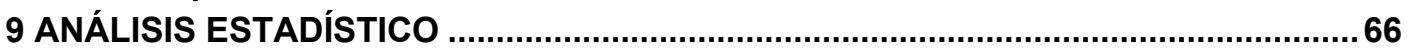

10 ANÁLISIS DE LAS INTERACCIONES GENÉTICAS ...........................................66

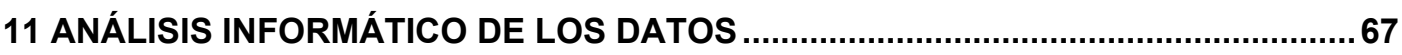

\begin{tabular}{lr} 
Resultados & 69 \\
\hline
\end{tabular}

1 RELACIÓN DE LA RUTA RIM101 CON LA PARED CELULAR ..................................71

1.1 Caracterización fenotípica del mutante yn/294A.............................................71

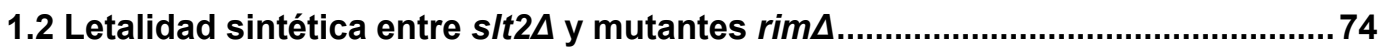

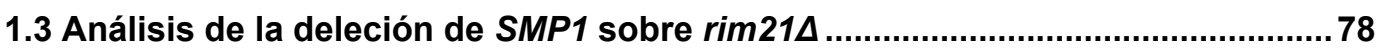

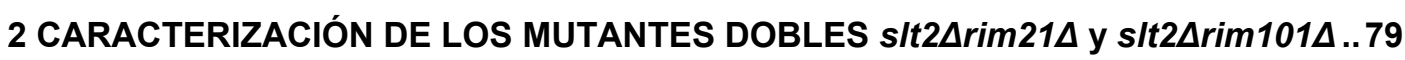

2.1 Caracterización fenotípica de los mutantes dobles............................................79

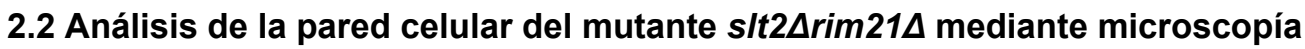

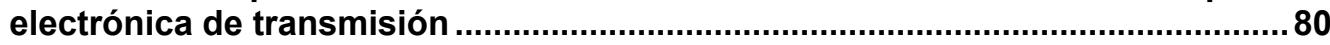

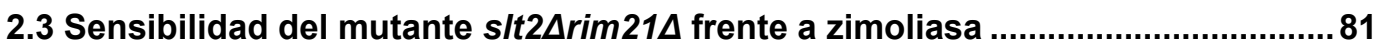

3 SUPRESORES DE LA LETALIDAD SINTÉTICA DE sIt2Arim1014 ...........................83

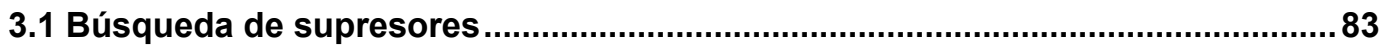

3.2 La supresión mediada por GFA1: una cuestión de quitina...................................87

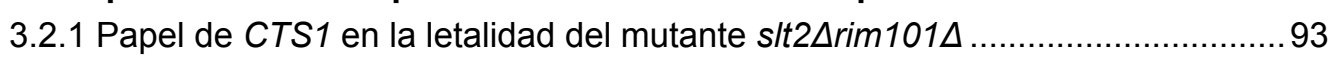


3.2.2 Ultraestructura del septo de slt2 $\Delta$ rim $101 \Delta$ .97

3.3 El ensamblaje de la maquinaria del cuello en ausencia de SLT2 y RIM101 .......99

3.3.1 Ensamblaje del complejo QSIII .......................................................... 99

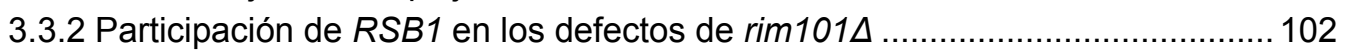

3.3.3 Localización de las proteínas de la maquinaria de septación y papel de

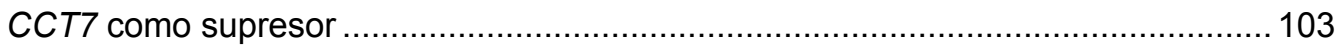

4 CARACTERIZACIÓN DE LOS SUPRESORES RESTANTES................................... 107

4.1 Supresión de slt2

5 UN APORTE TÉCNICO: DEGRADACIÓN PROTEOLÍTICA ARTEFACTUAL EN MUTANTES $\operatorname{rim} 101 \Delta$ MEDIADA POR Prb1p.......................................................... 112

Discusión 115

1 LA RUTA RIM101 POSEE UN PAPEL EN LA CONSTRUCCIÓN DE LA PARED

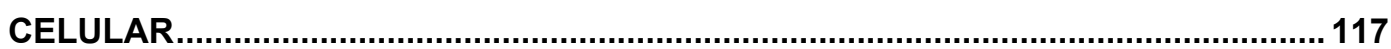

1.1 YnI294p/Rim21p es un miembro de la ruta RIM101 y participa en el ensamblaje de la pared celular

1.2 Rim101p colabora en la construcción de la pared gracias a su papel como regulador transcripcional.

2 LA PRESENCIA CONJUNTA DE SIt2p Y Rim101p RESULTA IMPRESCINDIBLE

EN LA INTEGRIDAD DEL CUELLO

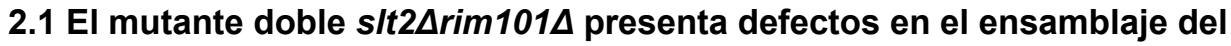
anillo de quitina

2.2 SIt2p y Rim101p contribuyen de manera independiente en el correcto ensamblaje de la maquinaria de septación

2.3 Papel homeostático del anillo de quitina en la integridad del cuello 



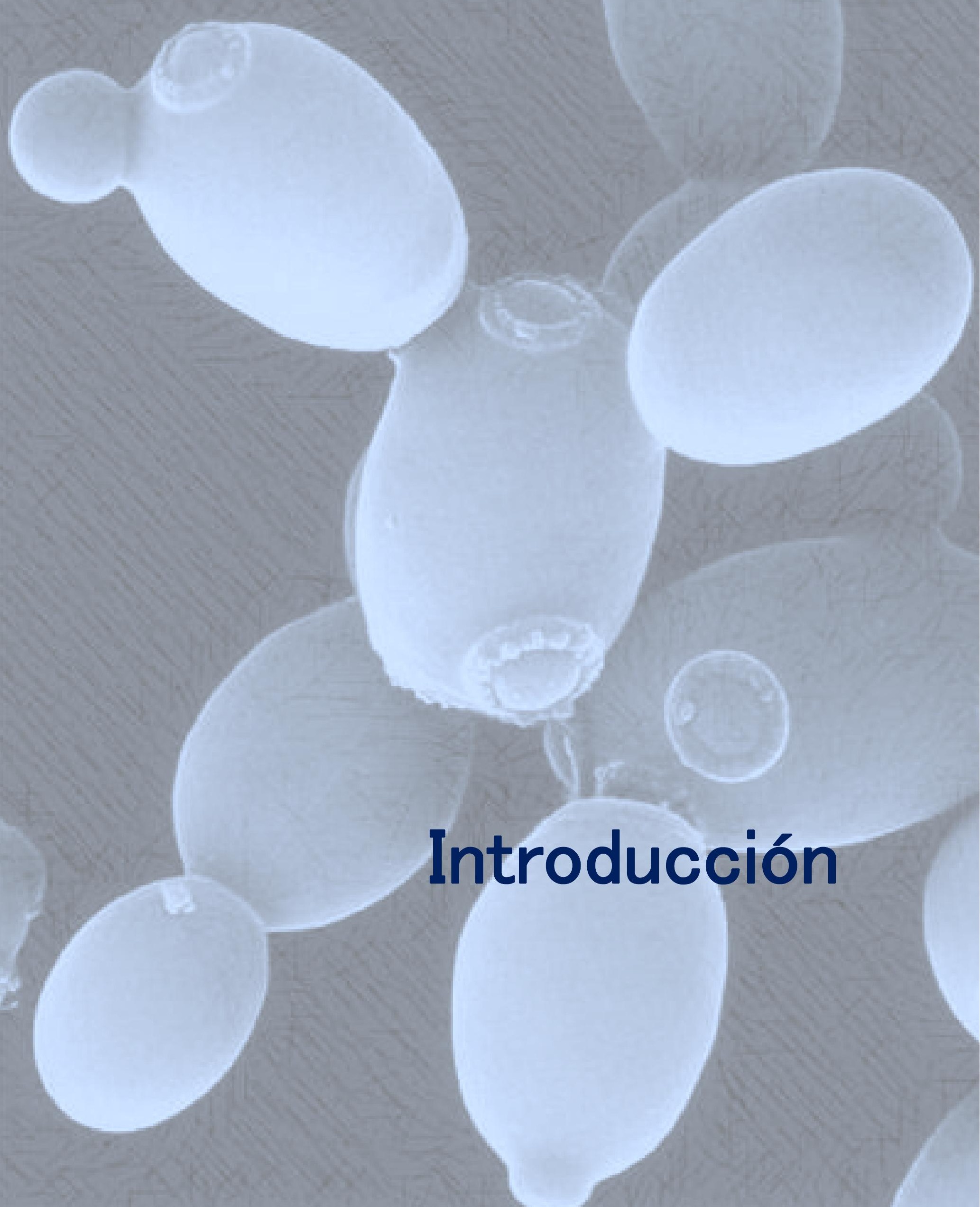



Saccharomyces cerevisiae, nuestro modelo de estudio, es conocida como "la levadura del pan" o "la levadura de la cerveza" debido a su uso industrial en la obtención de estos alimentos gracias a su capacidad fermentativa. También se la denomina como "la levadura de gemación" por su peculiar forma de propagación a través de la formación y posterior separación de una yema. S. cerevisiae también ha sido empleada en la producción de algunas proteínas recombinantes a escala industrial, como la primera vacuna de origen recombinante aprobada para su uso en humanos (la vacuna contra la hepatitis B) o el primer producto de origen recombinante aprobado para su uso alimentario (la renina utilizada para la fabricación de quesos). Además, es un microorganismo ideal para realizar estudios genómicos y biológicos. Algunas de las características que lo han convertido en un organismo modelo para la investigación son las siguientes:

- Facilidad de cultivo en el laboratorio en medios de bajo coste, mostrando un rápido crecimiento con un tiempo de generación de entre una y dos horas.

- Estatus GRAS (Generally Recognized As Safe) y ausencia de patogenicidad, carente por ello de cualquier tipo de riesgos.

- Simplicidad en su manipulación genética y facilidad en el aislamiento de mutantes.

- Alto grado de conservación de su fisiología celular en eucariotas superiores.

El genoma de S. cerevisiae fue el primero de tipo eucariótico en ser secuenciado de forma completa en 1996, posibilitando la caracterización funcional de sus genes mediante estrategias globales como el análisis fenotípico de mutantes, análisis de expresión génica con el uso de microarrays, análisis de interacciones proteicas, y otras estrategias y tecnologías que se están desarrollando y mejorando constantemente. Por todo ello, las características favorables que presenta esta levadura hacen que sirva como base para la investigación en organismos más complejos, habiendo permitido la identificación de numerosas proteínas humanas implicadas en diversas patologías.

\section{CICLO DE VIDA Y MORFOGÉNESIS}

S. cerevisiae es un organismo unicelular eucariótico cuya morfología es elipsoidal. Presenta tres tipos celulares diferentes: células haploides a, células haploides $\alpha$ y células diploides $a / \alpha$, jugando cada una de ellas un papel determinado en su ciclo de vida, 
dependiendo de las condiciones ambientales. Tanto la fase haploide como la diploide son estables y siguen un ciclo mitótico, reproduciéndose de forma asexual mediante gemación. Durante este ciclo mitótico, cuando la célula alcanza un tamaño determinado al final de la fase G1, se produce la emergencia de una célula hija denominada yema (Figura 1). El crecimiento inicial de ésta es apical, implicando la polarización del citoesqueleto de actina y la secreción direccional de los componentes necesarios para la formación de la pared celular (PC). Cuando la célula hija alcanza un tamaño determinado, su crecimiento cambia a isotrópico, produciéndose deposiciones de celular uniformemente por toda la yema. Durante estas fases, la superficie de la célula madre no se incrementa. Una vez que la célula hija recibe un núcleo tras la mitosis, tiene lugar la formación del septo que separa físicamente a células madre e hija. Posteriormente se produce la degradación de parte del mismo, originándose la separación física de ambas células. La separación da lugar a una marca denominada cicatriz de gemación en la célula madre. La célula hija, de tamaño inferior a la célula madre, todavía debe aumentar su tamaño antes de entrar en un nuevo proceso de división.

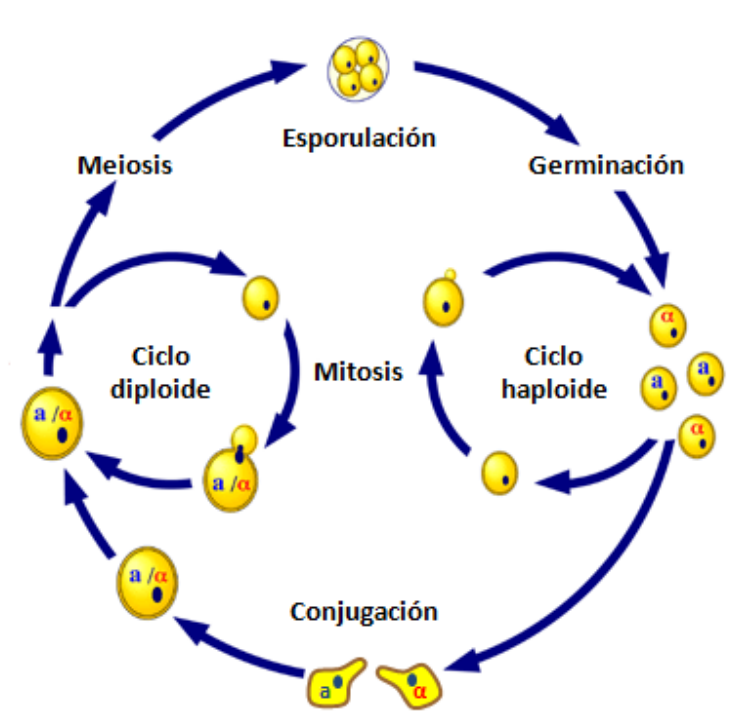

Figura 1. Ciclo de vida de S. cerevisiae. Se muestran los distintos estadíos celulares de la levadura (ver texto para consultar detalles).

Además de esta reproducción asexual, las células haploides de tipo sexual opuesto ( a y $\alpha$ ) pueden llevar a cabo el proceso denominado conjugación. Como respuesta a la feromona secretada por el tipo sexual opuesto (factores $\alpha$ y a, respectivamente), se 
produce una parada del ciclo celular en G1. Continúa con la transcripción de genes específicos de conjugación y una serie de cambios bioquímicos y morfológicos que culminan en la creación de unas células diferenciadas denominadas shmoos. Cuando dos shmoos de tipo sexual opuesto se fusionan, originan un zigoto diploide a/ $\alpha$ estable que se divide vegetativamente mediante gemación (Bardwell, 2005).

Estas células diploides ni producen ni responden a las feromonas anteriormente descritas, pero son capaces de salir del ciclo mitótico en condiciones de estrés nutricional. Cuando esto ocurre, entran en un programa de diferenciación estrictamente regulado que se conoce como esporulación. En primer lugar se origina una parada en fase G1 de la célula diploide, seguida por dos divisiones meióticas sucesivas. Esto conduce a la formación de una estructura especializada que se conoce como asca y que contiene cuatro ascosporas, dos de cada tipo sexual. La pared de las ascosporas es una estructura muy especializada que les permite sobrevivir en condiciones adversas. Cuando las condiciones ambientales son favorables, se produce la germinación de las ascosporas, saliendo de su estado latente y volviendo de nuevo a entrar en el ciclo celular mitótico de las células haploides.

Además, determinadas cepas diploides de S. cerevisiae pueden adoptar una forma de crecimiento hiperpolarizada denominada pseudohifa en respuesta a la ausencia de nitrógeno en el medio de cultivo. Cuando esto ocurre, las células se alargan, creciendo de manera unipolar y manteniéndose unidas como cadenas de células que pueden invadir el medio sólido. De manera similar, las células haploides, en respuesta a un agotamiento de la glucosa del medio, pueden desarrollar un crecimiento invasivo haploide, que desemboca a un cambio desde una morfología celular más redondeada y un patrón de gemación axial en la superficie del agar, a células alargadas con un patrón de gemación bipolar que les permite formar filamentos, y gracias a ello, penetrar en el medio de cultivo. Se cree que es una adaptación de los organismos no móviles para buscar alimento en ausencia de nutrientes (Palecek et al., 2002).

\section{LA PARED CELULAR FÚNGICA}

Como puede deducirse de lo expuesto anteriormente, $S$. cerevisiae posee una forma celular característica que es mantenida por una estructura denominada pared celular. La pared celular es una estructura externa a la membrana plasmática (MP) que se 
encuentra en contacto directo con el medio que rodea a las células y está formada por distintos tipos de macromoléculas. Su función fundamental es la estructural, aunque además algunos de sus componentes tienen un papel importante en procesos de agregación (Lipke \& Kurjan, 1992) y otras sirven de anclaje para diversas actividades enzimáticas relacionadas con su propio ensamblaje (Cid et al., 1995). A pesar de su aparente rigidez, que le permite actuar como una estructura de protección, la pared celular es considerablemente plástica y dinámica, ya que debe ser capaz de adaptarse a las numerosas modificaciones que ocurren a lo largo del ciclo de vida de la célula fúngica. Ésta sufre cambios en su composición durante su crecimiento vegetativo, así como durante otros procesos de diferenciación celular como son la esporulación y la conjugación. Además, también es capaz de responder frente a factores externos que pueden afectar a la integridad celular, todo ello a través de un equilibrio constante entre la síntesis y degradación de los polímeros que la componen.

A modo de resumen, se puede afirmar que la pared celular de $S$. cerevisiae posee cuatro funciones principales (Klis et al., 2006):

- Mantiene la homeostasis osmótica.

- Protege frente al estrés físico.

- Determina su morfología (función estrechamente ligada a la morfogénesis).

- Actúa como una estructura de anclaje a diversas glicoproteínas, lo cual le permite ser impermeable frente a macromoléculas e iones nocivos.

Se pueden mencionar dos razones principales por las que el estudio de la pared celular fúngica es de gran interés. Por un lado, es un buen modelo para entender los procesos morfogenéticos y de diferenciación desde un punto de vista molecular. Por otro lado, es una estructura ampliamente distribuida en todos los grupos taxonómicos de hongos y esencial para su supervivencia celular, siendo a su vez una estructura diferencial exclusiva de hongos, por lo que constituye una excelente diana para el diseño de antifúngicos de toxicidad selectiva (Odds et al., 2003). 


\subsection{Composición de la pared celular}

A pesar de estar presente tanto en bacterias como en hongos y plantas, la composición de la pared celular es muy diferente en cada uno de ellos. De hecho es una estructura muy variable dentro de los diversos grupos taxonómicos del propio Reino Fungi, tanto en su composición como en su estructura, lo cual ha sido utilizado para la clasificación taxonómica del mismo (Bartnicki-Garcia, 1968).

Centrándonos ya en el objeto de estudio, la pared celular de S. cerevisiae representa, dependiendo de las condiciones de crecimiento, aproximadamente el 10-25\% del peso seco de la célula y ocupa el $25-50 \%$ del volumen de la misma. Los componentes fundamentales de la pared son polisacáridos $(\approx 85 \%)$ y proteínas $(\approx 15 \%)$ (Revisado en Lesage \& Bussey, 2006). Los cuatro tipos de macromoléculas que constituyen la pared celular son: $\beta$-(1,3)-glucano, $\beta$-(1,6)-glucano, quitina y manoproteínas, siendo las proporciones en las que se presentan las indicadas en la tabla 1.

Tabla 1. Composición de la pared celular de S. cerevisiae.

\begin{tabular}{|c|c|}
\hline Macromolécula & Peso seco de la pared (\%) \\
\hline Manoproteínas & $30-50$ \\
\hline$\beta-(1,3)$-glucano & $30-45$ \\
\hline$\beta-(1,6)$-glucano & $5-10$ \\
\hline Quitina & $1,5-6$ \\
\hline
\end{tabular}

\subsection{Estructura molecular de la pared celular}

El análisis de la pared celular mediante microscopía electrónica revela que ésta se encuentra estructurada en dos capas (Osumi, 1998): una más interna y menos densa a los electrones, de aspecto fibrilar, compuesta por $\beta$-(1,3)-glucano y quitina. Ésta sirve de anclaje para otra más externa y densa a los electrones, de aspecto amorfo, que está formada por manoproteínas (Figura 2). 
El polisacárido más abundante en hongos es el $\beta$-(1,3)-glucano, que se encuentra moderadamente ramificado. La presencia de cadenas laterales, unidas mediante puentes de hidrógeno, da lugar a la formación de una red tridimensional altamente elástica. Los extremos no reductores del $\beta$-(1,3)-glucano permiten la formación de uniones covalentes con otros polisacáridos, como la quitina, que se une hacia el interior, y el $\beta$-(1,6)-glucano, que lo hace hacia el exterior. El $\beta$-(1,6)-glucano se encuentra altamente ramificado y a través de sus extremos no reductores sirve como intermediario para el anclaje de las GPICWPs. Además existen otras manoproteínas, las ASL-CWP (Alkali-Sensitive Linkage Cell Wall Proteins) que se unen covalentemente de forma directa a los extremos no reductores del $\beta$ (1,3)-glucano (Klis et al., 2006).

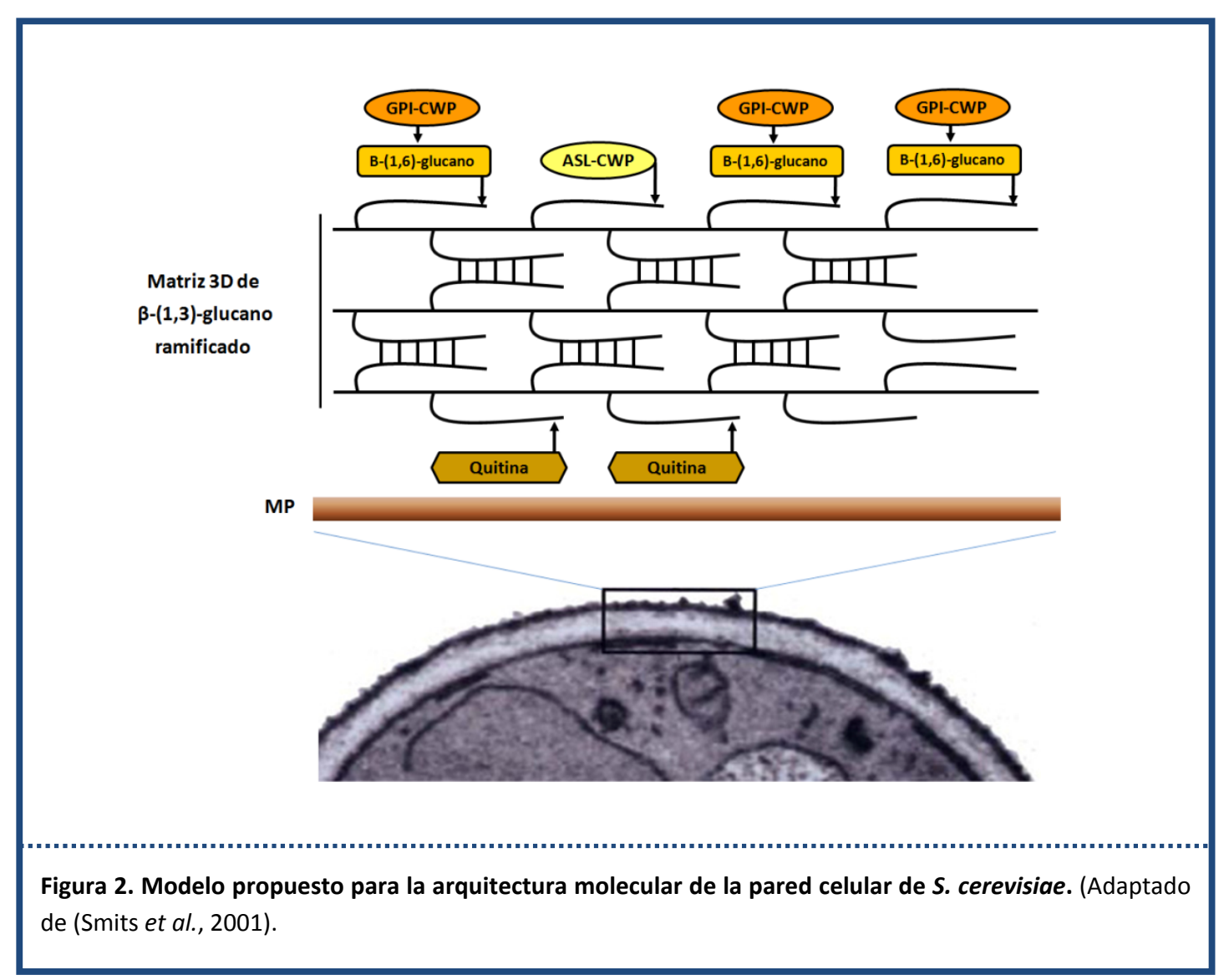

\subsection{Biosíntesis de los compuestos de la pared celular}

A continuación se describe brevemente la estructura de cada uno de los componentes de la pared celular, así como su biosíntesis e interconexiones. Para una 
revisión más detallada se recomienda la lectura de los siguientes artículos: (Klis et al., 2006; Lesage \& Bussey, 2006).

\subsection{1 $\beta-(1,3)-G l u c a n o$}

El $\beta$-(1,3)-glucano es un polímero constituido por alrededor de 1500 unidades de glucosa en cada cadena unidas mediante enlaces $\beta-(1,3)$, con ramificaciones de tipo $\beta-(1,6)$ en menor proporción. Posee una estructura helicoidal que confiere tanto elasticidad como fuerza de tensión a la pared (Kollar et al., 1995; Klis et al., 2002). Este polímero se encuentra unido covalentemente al resto de componentes de la pared, originando una compleja red tridimensional (Kollar et al., 1997).

La actividad $\beta$-(1,3)-glucán sintasa se localiza en la membrana plasmática y posee una fracción de membrana insoluble y otra citosólica, que se corresponden con las subunidades catalíticas y reguladora, respectivamente (Cabib et al., 1998). Las subunidades catalíticas son las proteínas homólogas Fks1p, Fks2p/Gsc2p y Fks3p, y emplean UDP-glucosa como sustrato. FKS1 se expresa principalmente durante el crecimiento vegetativo, mientras que FKS2 lo hace en respuesta a feromonas, calcio extracelular, altas temperaturas, daños sobre la pared celular, estrés nutricional y esporulación (Mazur et al., 1995). FKS3, con una alta similitud de secuencia a $F K S 1$ y $F K S 2$, participa únicamente en el ensamblaje de la pared de las esporas (Ishihara et al., 2007). Por otro lado, la GTPasa Rho1p es considerada la subunidad reguladora de la actividad $\beta$-(1,3)-glucán sintasa (Revisado en Levin, 2005). Además, juega un papel importante en el establecimiento de la polaridad celular, progresión del ciclo a través de G1 y la activación de la ruta de integridad celular. Esta proteína actúa como un interruptor molecular, ya que se puede encontrar en dos estados: el activo, unido a GTP y necesario para la activación de la síntesis del glucano, y otro inactivo, unido a GDP.

Se conoce la existencia de otras proteínas, como la transglicosidasa Gas1p, que es capaz de intervenir en la transferencia de polímeros de $\beta$-(1,3)-glucano recién sintetizados a los ya preexistentes (Mouyna et al., 2000). 


\subsection{2 $\beta-(1,6)-G l u c a n o$}

El $\beta$-(1,6)-glucano es un polímero formado por aproximadamente 350 residuos de glucosa en cada cadena unidos mediante enlaces $\beta-(1,6)$, siendo más cortas que las del $\beta$ (1,3)-glucano (Kollar et al., 1997). Presenta un gran número de ramificaciones que le permiten formar uniones covalentes con el $\beta$-(1,3)-glucano, la quitina y las manoproteínas, actuando por ello como masa cementante con una estructura amorfa.

A pesar de todas las aproximaciones genéticas y bioquímicas realizadas hasta la fecha, no se conocen ni la localización ni la forma en que se sintetiza este polímero en $S$. cerevisiae. Existen dos hipótesis: que se sintetice en el retículo endoplásmico (RE) y vaya madurando durante la secreción hasta la pared celular, o bien que su síntesis tenga lugar en la membrana plasmática (Klis et al., 2002). Se han descrito varios genes involucrados en la ruta de secreción que afectan a la síntesis del $\beta$-(1,6)-glucano, pero que no están directamente relacionados con dicha síntesis (Shahinian \& Bussey, 2000), por lo que no se ha logrado hasta el momento la identificación del gen (o genes) que codifica la $\beta$-(1,6)glucán sintasa.

\subsubsection{Quitina}

Este polímero está formado por cadenas lineales de residuos de $\mathrm{N}$-AcetilGlucosamina unidos mediante enlaces $\beta-(1,4)$ y de longitud variable. Es el componente minoritario de la pared celular, aunque es esencial para la supervivencia de esta levadura. La quitina aparece distribuida de forma desigual en diferentes localizaciones celulares. Las cadenas nacientes de este polímero se secretan al espacio periplásmico, ensamblándose en una conformación fibrilar y cristalina denominada $\alpha$-quitina, en la que las cadenas lineales se disponen de forma antiparalela y/o paralela a través de puentes de hidrógeno.

La quitina es sintetizada por una familia de enzimas llamadas quitín sintasas. El número de estas enzimas varía dependiendo del organismo y será discutido con más detalle en capítulos posteriores. Cabe destacar la existencia de dos transglicosidasas redundantes, Crh1p y Crh2p/Utr2p, necesarias para catalizar la transferencia de quitina tanto al $\beta-(1,3)$ glucano, como al $\beta$-(1,6)-glucano (Cabib et al., 2008). 


\subsubsection{Manoproteínas}

Una parte importante de la pared son las manoproteínas, que poseen un alto contenido en carbohidratos unidos a la secuencia peptídica mediante enlaces $\mathrm{N}$ u Oglicosídicos (Revisado en Lesage \& Bussey, 2006). Estas proteínas se acumulan en la parte más externa, constituyendo la capa más oscura y densa a los electrones (Figura 2).

La mayoría de las proteínas de la pared celular (CWPs) son GPI-CWPs, que presentan una molécula de glucosil fosfatidil inositol (GPI) gracias a la cual llegan a la membrana plasmática. Posteriormente estas proteínas se anclarían de forma indirecta a la matriz de $\beta$-(1,3)-glucano a través del $\beta$-(1,6)-glucano, localizándose hacia el exterior de la pared celular.

También existen otras proteínas, las ASL-CWPs, que se unen directamente al $\beta$ (1,3)-glucano mediante un tipo de unión sin identificar, pero sensible al álcali. Estas proteínas incluyen la familia de las Pir-CWPs (Proteins with Internal Repeats).

Las funciones desempeñadas por las manoproteínas son muy variadas. Algunas de ellas tienen una función estructural, reforzando la pared. Otras están implicadas en procesos de adhesión célula-célula, retención del agua y permeabilidad selectiva, y hay otras que incluso poseen actividad enzimática, como puede suponer la propia remodelación y reparación de la pared. Entre ellas cabe destacar a las ya citadas Gas1p, Crh1p y Crh2p.

\subsection{Dinámica y remodelación de la pared celular}

La síntesis y ensamblaje de la pared celular es un proceso complejo y se han encontrado más de 1200 genes cuya deleción afecta directa o indirectamente a esta estructura. La composición, estructura y espesor de la pared varían considerablemente dependiendo de múltiples factores ambientales como son los niveles de oxígeno, la composición del medio de cultivo, temperatura, $\mathrm{pH}$, etc. Además existen diversos tipos celulares, como son las yemas, los shmoos, las ascosporas y la pseudohifa, lo cual implica la adaptación permanente de la pared celular en cada uno de los casos para garantizar la integridad celular a lo largo de todas las fases del ciclo celular. 
Un caso específico de remodelación ocurre cuando la pared celular se ve sometida a un daño. En esta situación se produce la activación de la ruta de integridad celular (CWI, Cell Wall Integrity) (Levin, 2005), a la cual se dedica un apartado de la memoria más adelante. Existen diversos estímulos que pueden producir la activación de esta ruta como son, entre otros, el ataque a la pared celular producido por enzimas líticas, el estrés hipotónico y térmico, o mutaciones que debilitan la pared, que en último término ocasionan un incremento en la tensión de la membrana plasmática. De forma general podemos decir que esta remodelación ocurre a través de tres vías:

- Un incremento de los componentes de la pared celular, como por ejemplo la quitina, que aumenta notablemente hasta alcanzar el $20 \%$ del peso seco de la pared.

- Cambios en la expresión e incorporación de las CWPs a la pared celular y en el ensamblaje entre los propios polímeros que la constituyen.

- Despolarización transitoria del citoesqueleto de actina, que desencadena la redistribución de los complejos de síntesis de quitina y glucano hacia zonas concretas.

Una buena parte de esta respuesta está controlada por la activación del factor de transcripción RIm1p, que permite un incremento en la expresión de numerosos genes implicados en la síntesis o remodelación de la pared celular.

\section{LA QUITINA}

Este polisacárido es el segundo polímero natural más abundante en la naturaleza después de la celulosa. Está presente en las paredes celulares de prácticamente todos los hongos, en el resistente exoesqueleto de los artrópodos, y en otros animales como anélidos y cnidarios, encontrándose ausente en animales y plantas. Esto convierte a la quitina en una diana potencial ideal a la hora de desarrollar nuevos antifúngicos de toxicidad selectiva.

La quitina se sintetiza a partir de un precursor, la Uridina-Difosfo-N-AcetilGlucosamina (UDP-NAcGIn), que es empleada como sustrato en la reacción catalizada por 
las enzimas con actividad quitín sintasa (QS), sin haberse encontrado hasta la fecha un aceptor primario:

$$
\text { 2n UDP-NAcGln } \rightarrow[N A c G l n-\beta(1,4)-N A c G I n]_{n}+2 n \text { UDP }
$$

La síntesis de quitina es un proceso complejo que debe estar regulado finamente, puesto que su acción está restringida espacial y temporalmente durante el ciclo celular. En S. cerevisiae existen tres actividades QS con mecanismos de regulación específicos para cada una de ellas. Para una revisión más detallada, consultar Valdivieso et al., 2004.

\subsection{Actividad Quitín Sintasa I}

A comienzos de la década de los 80 fueron aislados mutantes defectivos en la actividad quitín sintasa, gracias a los cuales se aisló el gen CHS1, un gen que resultó no ser esencial. Este gen codifica la subunidad catalítica de la actividad QSI. A pesar de que esta actividad es la mayoritaria in vitro, los mutantes chs1 $1 \Delta$ poseen cantidades normales de quitina in vivo. Esta actividad es zimogénica in vitro, es decir, que su actividad óptima se consigue tras un tratamiento previo con proteasas. El pH óptimo de esta actividad es 6.5 , se estimula en presencia de $\mathrm{Mg}^{2+}$ y NAcGln, y es inhibida por los iones $\mathrm{Co}^{2+}$ y Ni${ }^{2+}$ (Choi \& Cabib, 1994).

A pesar de que la QSI no es una enzima esencial, los mutantes chs1 $1 \Delta$ presentan un grado significativo de lisis en las yemas, justo después de la separación celular. Esta lisis se produce sólo en medio mínimo, condición en la que se promueve la actividad quitinasa. En base a estos datos se propuso que la actividad QSI actuaría contrarrestando el efecto lítico causado por las quitinasas, teniendo papel de reparación durante la citoquinesis (Cabib et al., 1992).

Aunque la expresión de CHS1 cambia a lo largo del ciclo celular, tanto los niveles de Chs1p como la actividad QSI se mantienen elevados y constantes a lo largo del mismo. La actividad QSI aumenta significativamente durante la conjugación y tras la activación de la respuesta compensatoria (Roncero, 2002), pero no se conoce la relevancia que pueda tener esta regulación, puesto que el mutante carente de esta actividad no muestra ningún fenotipo en dichas circunstancias. Chs1p es una proteína integral de membrana y se 
encuentra asociada a la membrana plasmática y a vesículas endocíticas denominadas quitosomas (Ver más adelante).

\subsection{Actividad Quitín Sintasa II}

CHS2 fue identificado a partir de mutantes carentes de la actividad QSI, denominándose Chs2 $p$ a la subunidad catalítica de la actividad QSII. Los niveles de actividad QSII suponen alrededor de un $10 \%$ de la actividad QSI in vitro, y también es zimogénica en estas condiciones, aunque no existen evidencias de que esto ocurra in vivo. El pH óptimo de esta actividad es 7.5-8.0 y se estimula en presencia de NAcGln y $\mathrm{Co}^{2+}$, siendo inhibida tanto por $\mathrm{Ni}^{2+}$ como por la droga polioxina $\mathrm{D}$ (Choi \& Cabib, 1994).

La actividad QSII posee un papel crítico en la formación del septo y división celular (Silverman et al., 1988). La QSII tan sólo es responsable del $10 \%$ de la síntesis de quitina in vivo, aunque los mutantes chs $2 \Delta$ crecen más lentamente y presentan células más grandes que aparecen formando agregados, ya que no se separan correctamente al presentar septos engrosados y amorfos en los que el septo primario (SP) está ausente. Se ha podido determinar que la QSII es la responsable de la síntesis de quitina del SP mediante técnicas de microscopía electrónica empleando WGA (lectina de germen de trigo que se une específicamente a la quitina) conjugada con oro coloidal (Shaw et al., 1991).

La actividad QSII está sometida a regulación transcripcional y postraduccional, puesto que tanto los niveles de ARNm de CHS2 como los de la proteína Chs $2 p$ oscilan a lo largo del ciclo celular, observándose un máximo tanto de los niveles de la proteína como de su actividad al final de mitosis. Además, la expresión de este gen se encuentra muy reducida durante la esporulación y conjugación, procesos en los que no se sintetiza SP. La proteína es muy inestable y posee una vida media bastante breve, de aproximadamente 25 minutos, lo que contribuye a su regulación durante el ciclo celular. Existen formas adicionales de control de esta actividad, ya que se ha demostrado que Chs $2 p$ es mantenida en el RE mediante la fosforilación dependiente de Cdk1p (Teh et al., 2009). A mayores de todas estas formas de regulación, Chs2 $p$ se localiza en el cuello de forma dependiente a la maquinaria del cuello (Roncero \& Sanchez, 2010). 


\subsection{Actividad Quitín Sintasa III}

\subsubsection{Características generales}

A lo largo de los años se han identificado mutantes carentes de QSIII mediante diferentes estrategias que incluyen resistencia a calcoflúor, síntesis de quitina in vivo, defectos en el ensamblaje de la pared celular de la espora o resistencia a la toxina killer de Kluyveromyces lactis (Valdivieso et al., 2004). Gracias a ello se han identificado varios genes (CHS3, CHS4, CHS5, CHS6 y CHS7) implicados directamente en la síntesis de quitina in vivo. CHS3 es el gen que codifica la subunidad catalítica de la actividad QSIII (Valdivieso et al., 1991), presentando la proteína Chs3p una homología reducida pero significativa con Chs1p y Chs2p. Todas ellas contienen el motivo QRRRW, necesario para la actividad catalítica (Cos et al., 1998).

La actividad QSIII in vitro representa aproximadamente el $5 \%$ respecto a los niveles de la QSI, pero es la encargada de sintetizar alrededor del 90\% de la quitina de la célula in vivo. La actividad no es zimogénica, aunque estudios más recientes demostraron que la QSIII presentaba esa propiedad cuando la extracción de las membranas se hacía en presencia de detergentes. La actividad QSIII presenta un pH óptimo de 7.5-8.0, siendo estimulada por los cationes $\mathrm{Mg}^{2+}$ y $\mathrm{Co}^{2+}$, además de por la NAcGln. Sin embargo el $\mathrm{Ni}^{2+}$, inhibidor de Chs1p y Chs2p, apenas tiene efecto sobre Chs3p (Choi \& Cabib, 1994). La actividad QSIII también se encuentra anclada en la membrana, apareciendo al igual que la actividad QSI en la membrana plasmática y en los quitosomas (Ver más adelante).

\subsubsection{Función y regulación de la actividad QSIII y caracterización de los genes implicados en dicha actividad}

Los mutantes chs $3 \Delta$ contienen tan sólo un $10 \%$ de la quitina presente en una cepa silvestre, y son perfectamente viables, mostrando defectos morfológicos mínimos (Valdivieso et al., 1991). La quitina celular sintetizada por Chs3p se localiza mayoritariamente en forma de anillo en la base de la yema ( $85 \%$ de la quitina total), y de forma minoritaria, uniformemente a lo largo de la pared lateral (Shaw et al., 1991). Además, la actividad QSIII también sintetiza la quitina presente en la base de la proyección del shmoo durante la conjugación, y la quitina que es posteriormente desacetilada para 
originar la capa de quitosán presente en las ascosporas (Valdivieso et al., 2004). Cuando se produce un daño en la pared celular que activa la respuesta compensatoria, la QSIII es la encargada del aumento en la síntesis de quitina (Popolo et al., 2001). Por último, cuando se ve comprometido el aparato de septación celular, la actividad QSIII es la encargada de sintetizar un septo de remediación gracias al cual se permite la división de la célula (Cabib \& Schmidt, 2003).

La actividad QSIII es por tanto responsable de la síntesis de la mayor parte de la quitina en diferentes estadíos del ciclo celular y es necesaria para responder rápidamente frente a daños sobre la pared celular, por lo que debe de estar sometida a una regulación muy compleja, requiriendo la actuación de múltiples proteínas que actúan a diferentes niveles. La ausencia de los genes que codifican las proteínas Chs ocasiona tanto resistencia frente al calcoflúor como ausencia de quitina, como se ha descrito anteriormente. La caracterización de estos genes CHS, identificados a partir del fenotipo de resistencia a calcoflúor, ha descrito una ruta de transporte intracelular para Chs3p, que posee unas características únicas que se resumen a continuación (Figura 3A):

Chs3p se sintetizaría en los ribosomas asociados al RE, adquiriendo aquí su conformación nativa. Chs7p actúa como una chaperona específica del RE que facilita la salida de Chs3p del RE (Trilla et al., 1999) impidiendo su agregación (Kota \& Ljungdahl, 2005). El proceso es también dependiente de su palmitoilación (Lam et al., 2006). Una vez que Chs3p ha salido del RE, llega al Golgi, donde es clasificada de forma dependiente de Chs5p (Santos et al., 1997) y de Chs6p, un miembro de una familia denominada ChAPs (Chs5p-Afr1p-binding Proteins) (Trautwein et al., 2006). La participación conjunta de Chs5p y diferentes ChAPs permite la carga de Chs3p en las vesículas que salen del Trans Golgi Network, permitiendo su posterior llegada a la MP.

La llegada final de Chs3p a la membrana depende de Chs4p, una proteína que actúa como activadora directa de la QSIII (Trilla et al., 1997). Chs4p interacciona directamente con Chs3p y Bni4p (DeMarini et al., 1997; Kozubowski et al., 2003) permitiendo el anclaje de la QSIII al anillo de septinas y la síntesis correcta del anillo de quitina (Sanz et al., 2004). 


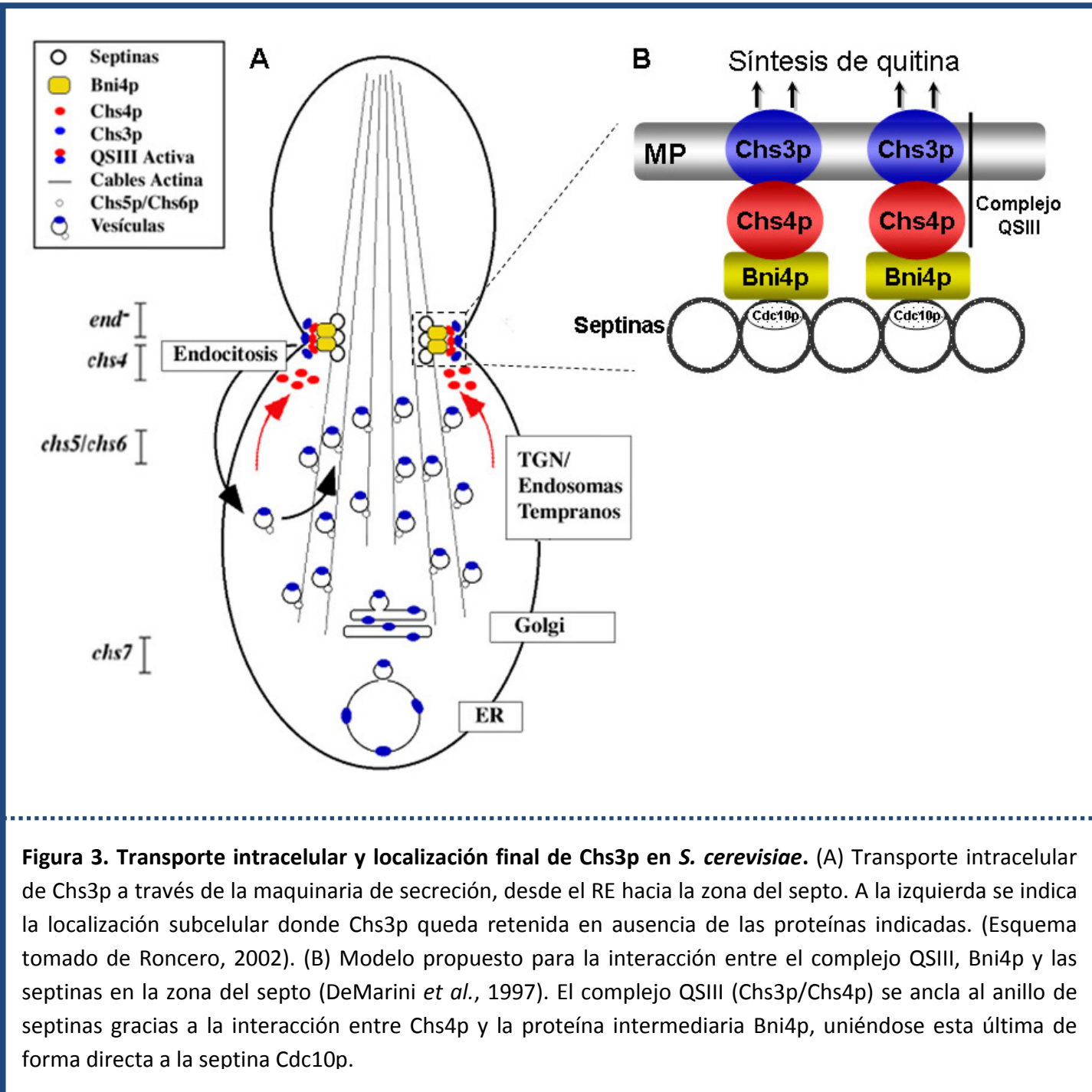

Aunque desconocemos todavía mucha información acerca del funcionamiento de Chs $4 p$, esta proteína es transportada en vesículas de forma polarizada y sin depender del resto de proteínas Chs (Reyes et al., 2007). Su asociación a la membrana se realiza gracias a un dominio de prenilación de la proteína en el extremo C-terminal, lo cual se ha relacionado directamente con la activación de Chs3p (Grabinska et al., 2007). En ausencia de prenilación, Chs4p puede dirigirse al cuello gracias a su interacción con otras proteínas, principalmente Chs3p. Chs4p induce la activación de la QSIII mediante la translocación de Chs3p en la membrana plasmática en una forma estable y activa, manteniéndose correctamente polarizada gracias al equilibrio dinámico entre su transporte anterógrado hacia la zona del septo y su reciclaje endocítico en esa región, que es dependiente de Chs $4 p$ (Reyes et al., 2007). 
De forma general podemos concluir que la QSIII se regula de forma postraduccional en todas las condiciones de crecimiento, incluyendo conjugación y esporulación. Existen sin embargo formas específicas de regulación todavía poco exploradas, pero que pueden quedar resumidas en lo que conocemos sobre la esporulación, donde el papel de Chs $4 p$ es reemplazado por su homóloga funcional Shc1p, específicamente expresada durante este proceso (Sanz et al., 2002).

\section{FORMACIÓN DEL SEPTO Y SEPARACIÓN CELULAR}

\subsection{Formación del septo}

En células animales, la citoquinesis se produce gracias a la contracción de un anillo de actomiosina, que da lugar a la invaginación de la membrana plasmática. Cuando se produce la fusión de la membrana en la zona media, se originan las dos células hijas. En el caso de las células fúngicas, el proceso se ve dificultado por la existencia de la pared celular, una estructura rígida que rodea a la membrana plasmática y que requiere de la síntesis de un septo. En este caso, la contracción del anillo de actomiosina debe estar perfectamente regulada espacial y temporalmente con la síntesis de nuevos fragmentos tanto de la membrana plasmática como del SP, sobre el cual se depositan más capas de pared celular, y que finalmente terminan siendo degradados de forma parcial por enzimas hidrolíticas.

En S. cerevisiae la división celular se da lugar en el cuello, una zona estrecha de separación entre las células madre e hija (para una revisión más detallada sobre la septación y la citoquinesis se recomiendan los artículos de revisión de (Cabib, 2004; Roncero \& Sanchez, 2010). Existen una serie de acontecimientos que originan la formación del septo y que se suceden de la siguiente manera (Figura 4). Inicialmente aparecen las septinas (Cdc3p, Cdc10p, Cdc11p, Cdc12p y Shs1p), que forman un anillo en el sitio de división, sirviendo como estructura de andamiaje para otras proteínas involucradas en el proceso. Las septinas suponen además una barrera de permeabilidad, generándose por todo ello la asimetría celular necesaria para una adecuada coordinación de los procesos morfogenéticos (Dobbelaere \& Barral, 2004). Este anillo de septinas marca el ensamblaje localizado de la QSIII que se encarga de sintetizar el anillo de quitina que rodea al cuello. La síntesis de este polímero se mantiene a lo largo de la mayor parte del ciclo celular, 
sirviendo el anillo como un andamiaje en el ensamblaje de otros componentes del septo (Ver más adelante).

Para que se produzca el ensamblaje del anillo de actomiosina, deben llegar a la zona del cuello tanto las forminas como otras proteínas reguladoras de la actina, necesarias para el ensamblaje de la misma en el anillo (Moseley \& Goode, 2006). Al final de la mitosis se produce la reorganización de las septinas originándose dos anillos en la zona del cuello. En el espacio formado entre ambos, la proteína Chs2p se ancla en la membrana (Teh et al., 2009), y se acumula la F-actina, permitiéndose el ensamblaje del anillo de actomiosina. Este anillo se contrae inmediatamente invaginando con él a la membrana plasmática, al mismo tiempo que un disco de quitina es sintetizado por la actividad QSII depositándose en la invaginación y dando lugar al SP, mientras el anillo contráctil acaba desapareciendo. Las membranas plasmáticas acaban fusionándose, y se concluye así la citoquinesis. En este momento Chs2p es endocitado y degradado (Schmidt et al., 2002), aunque la septación continúa. El modelo actual contempla la dependencia entre la síntesis del SP y la contracción del anillo (Schmidt et al., 2002).
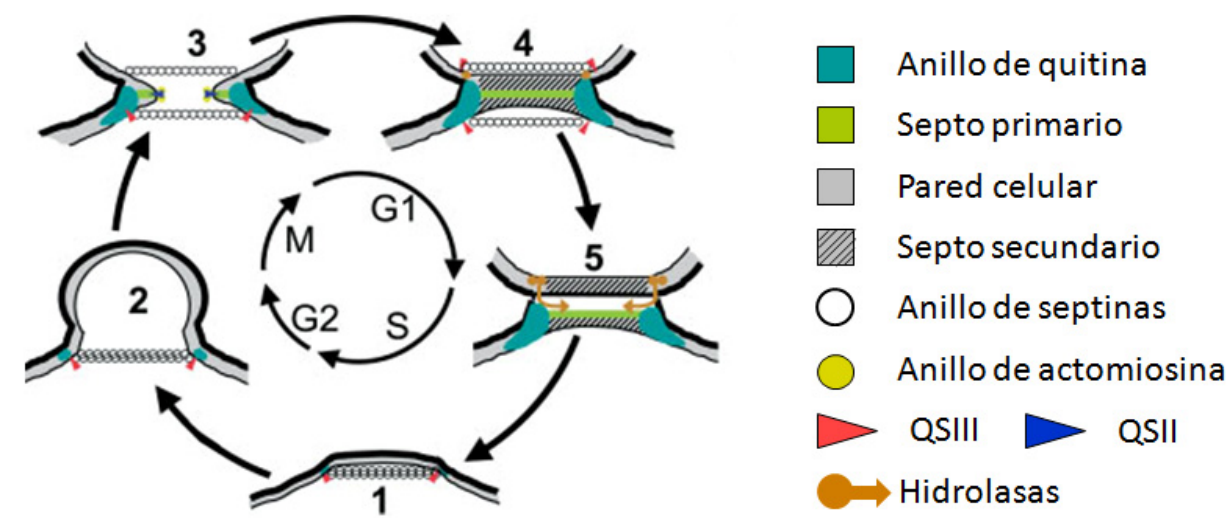

Figura 4. Eventos que se suceden en el ensamblaje del septo en $S$. cerevisiae a lo largo del ciclo celular. Una vez que se ha seleccionado el sitio de gemación, la maquinaria encargada de la síntesis y ensamblaje del septo se posiciona en la región del cuello ( 1 y 2 ), posibilitando la síntesis del anillo de quitina. Se sintetiza el septo primario (SP) (disco de quitina) (3). A ambos lados del SP se deposita material de pared celular, originando el septo secundario (SS) (4). Finalmente actúan enzimas hidrolíticas que causan la separación celular (5) (Esquema tomado de Roncero \& Sanchez, 2010).

A continuación, a ambos lados del SP se deposita el septo secundario (SS), que está constituido por material de pared celular similar al de la pared lateral, pero con una composición que no se conoce de manera exacta aún, aunque se sabe que contiene $\beta-(1,3)$ 
y $\beta$-(1,6)-glucano y quitina. De igual manera cabe destacar que el $\beta$-(1,3)-glucano forma parte tanto del SS como del SP, estando una pequeña parte de él unido a quitina (Cabib \& Duran, 2005). Por ello la subunidad catalítica de la $\beta$-(1,3)-glucán sintasa Fks1p tendría un papel en la formación del septo, aunque poco se sabe sobre ello. También se ha visto que las transglicosidasas Crh1p y Crh2p se localizan en el cuello y pueden actuar en el ensamblaje del septo uniendo el $\beta$-(1,6)-glucano a la quitina sintetizada por QSIII (Cabib et al., 2007). De igual manera, la $\beta$-(1,3)-transglicosidasa Gas1p posee la misma localización, requiriendo para ello un anillo de quitina y un septo funcional, además de las proteínas Crh1p y Crh2p (Rolli et al., 2009). Finalmente se debe producir la separación física de ambas células, gracias al papel que desempeñan de forma mayoritaria dos enzimas hidrolíticas: la quitinasa Cts1p y la endoglucanasa Eng1p (Ver más adelante). La mayoría del SP, junto con el anillo de quitina, permanece en el lado de la célula madre debido a la actuación de las enzimas hidrolíticas desde el lado de la célula hija, originando así la cicatriz de gemación.

Cuando falla la síntesis del SP, la actividad QSIII se vuelve imprescindible y es la encargada de la síntesis de un septo de remediación en los mutantes con defectos en la formación del SP (Cabib \& Schmidt, 2003). A pesar de no formar propiamente parte de la maquinaria de septación, Chs3p también es importante porque da lugar a la síntesis del anillo de quitina que rodea al SP. El complejo Chs3p-Chs4p se ancla al anillo de septinas gracias a la proteína intermediaria Bni4p, y se mantiene en la zona del cuello durante gran parte del ciclo celular (Kozubowski et al., 2003). La integridad del cuello durante la citoquinesis depende de la coexistencia de este anillo de quitina y del anillo de septinas (Schmidt et al., 2003), desembocando la ausencia de ambas estructuras en la muerte celular. La importancia del anillo de quitina también queda remarcada por el patrón de letalidad sintética que presenta el mutante chs3 $\Delta$ (Lesage et al., 2005).

\subsection{Separación celular}

La pared celular es una estructura enormemente dinámica que se mantiene a través del equilibrio continuo entre la síntesis, el ensamblaje y la remodelación de sus componentes. Una vez que se ha originado el septo entre las células madre e hija, se produce la separación celular mediante la degradación controlada de dicho septo llevada a cabo por enzimas hidrolíticas, cuya expresión asimétrica está controlada temporalmente 
por la ruta RAM. Tras la salida de mitosis, la quinasa Cbk1p, activada por Mob1p, se localiza en el cuello. Allí fosforila específicamente a Ace2p, permitiendo su acumulación en el núcleo de la célula hija (Parnell \& Stillman, 2008), donde da lugar a la expresión asimétrica de una serie de genes, entre los que se encuentran la quitinasa CTS1 (Colman-Lerner et al., 2001), la endoglucanasa más importante ENG1 (Baladron et al., 2002) y otras actividades hidrolíticas aún sin caracterizar. Estas enzimas son dirigidas a la zona del cuello, teniendo Cts1p el papel fundamental en la separación celular de $S$. cerevisiae, a través de su acción sobre la quitina del SP desde el lado de la célula hija, y siendo secundario el papel de Eng1p. Tanto la deleción de CTS1 como la de ACE2 originan un fenotipo de células encadenadas (Kuranda \& Robbins, 1991; Dohrmann et al., 1992). La QSI se encargaría de corregir el exceso de degradación causado por Cts1p (Cabib et al., 1992). Además, en determinadas circunstancias donde la actividad de la quitinasa es máxima, como a pH ácido, la ausencia de Chs1p acaba produciendo la lisis celular (Cabib et al., 1989).

\section{RUTAS DE TRANSMISIÓN DE SEÑALES}

\subsection{Introducción: generalidades}

Los mecanismos gracias a los cuales la célula es capaz de detectar y responder frente a las condiciones cambiantes del medio que le rodea han sido considerados de gran interés durante las últimas décadas. Además, se está poniendo en evidencia de forma cada vez más clara el alto grado de conservación que existe entre los sistemas de transmisión de señales en diferentes organismos eucariotas, teniendo por ello $S$. cerevisiae gran relevancia como modelo en estos estudios. Estos sistemas contienen sensores, transductores y efectores de la señal que regulan la expresión de genes y/o la función de proteínas de forma especializada dependiendo del estímulo que la active y la acción que se requiera.

Entre las rutas de señalización que existen, ocupan un lugar de gran importancia las denominadas cascadas MAP quinasa (Chen \& Thorner, 2007). Estas rutas contienen lo que se ha designado como módulo MAP quinasa, en el que la información fluye en cascada a través de tres proteínas con actividad quinasa. Éstas se fosforilan de forma sucesiva para poder transmitir intracelularmente una señal específica, que procede de proteínas receptoras situadas en la membrana plasmática. Cuando esto sucede, una proteína 
MAPKKK fosforila a la MAPKK, que a su vez activa también mediante fosforilación a la MAP quinasa (MAPK). Esta última se encarga generalmente, gracias a su transporte al núcleo, de regular la actividad de determinados factores de transcripción mediante fosforilación, dando lugar a la transcripción de unos genes que puedan desempeñar una respuesta adecuada a los estímulos que pusieron en marcha este mecanismo. Los módulos MAP quinasa aparecen conservados tanto en animales como en plantas y hongos.

Entre las cascadas de señalización que forman parte de $S$. cerevisiae se han descrito cinco rutas de transmisión de señales que se basan en módulos MAP quinasa (Chen \& Thorner, 2007). Éstas son conocidas como: ruta de respuesta a feromonas, ruta de pseudofilamentación/crecimiento invasivo, ruta de respuesta a alta osmolaridad (HOG), ruta para el ensamblaje de la pared celular de la espora y ruta de integridad celular (PKC) (Figura 5).

Asimismo existen otras rutas en las que su activación, a diferencia de las que se acaban de enumerar, no consiste en una cascada de proteínas MAP quinasa. Entre ellas están la ruta de la calcineurina y la ruta RIM101 o ruta de respuesta a pH alcalino (Figura 5). En esta última, su factor de transcripción es procesado proteolíticamente, originando así la respuesta transcripcional correspondiente. Aunque existen evidencias cada vez más abundantes que indican la existencia de una interacción entre muchas de estas rutas, aquí nos centramos tan sólo en dos de ellas, la ruta RIM101 y la ruta PKC o CWI (Cell Wall Integrity), activada frente a daños sobre la pared celular.

\subsection{Ruta de respuesta frente al pH alcalino: ruta RIM101}

\subsubsection{Introducción}

Los microorganismos deben adaptarse a múltiples condiciones ambientales, entre las que está el pH del medio en el que se encuentran, ya que éste tiene influencia en su crecimiento, fisiología y diferenciación. S. cerevisiae puede vivir en un amplio rango de $\mathrm{pH}$, aunque su crecimiento es óptimo a pH ácido. Para adaptarse a los cambios de $\mathrm{pH}$ o a una alta concentración extracelular de cationes, $S$. cerevisiae activa la expresión de genes específicos de bombas iónicas y transportadores, encontrándose entre ellos PMA1, ENA1 y una ATPasa vacuolar (Lamb et al., 2001). 


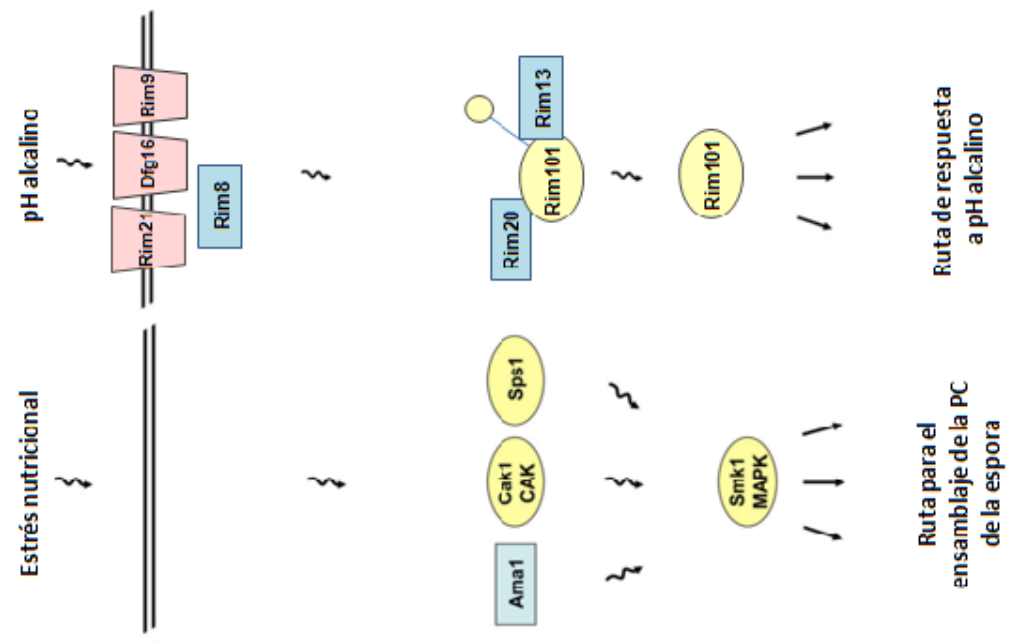


Mediante el uso de arrays para la hibridación de ADN, se ha determinado la inducción a gran escala de la expresión de genes provocada por la alcalinización del medio (Lamb et al., 2001). La gran mayoría de los genes que se encontraron son específicos de pH alcalino, estando involucrados en una gran variedad de procesos celulares. La respuesta transcripcional frente al pH extracelular se ha caracterizado de forma más extensa en hongos, siendo Aspergillus nidulans el organismo que sirve de modelo para su estudio, ya que este sistema de regulación implica una ruta de transducción bastante conservada. En ella participan los productos de los genes pacC, palA, palB, palC, palF, palH y pall (Revisado extensamente en (Penalva \& Arst, 2004). Esta ruta desencadena el procesamiento proteolítico de su factor de transcripción PacC, siendo requeridos los productos de los 6 genes pal para la activación del mismo. PacC sufre dos procesamientos proteolíticos sucesivos, siendo el primero dependiente de $\mathrm{pH}$ neutro o básico, y el segundo independiente de $\mathrm{pH}$ y catalizado por el proteosoma, permitiendo así que el factor de transcripción procesado ejerza como represor transcripcional de genes expresados en condiciones ácidas y activador de genes expresados en condiciones alcalinas.

\subsubsection{Ruta RIM101 de S. cerevisiae: activación y componentes}

S. cerevisiae posee una proteína homóloga de PacC denominada Rim101p. Éste es un factor de transcripción identificado inicialmente como un regulador positivo del programa meiótico, esporulación y crecimiento invasivo (Su \& Mitchell, 1993; Li \& Mitchell, 1997; Lamb et al., 2001). Actualmente se puede afirmar que la ruta RIM101 responde también a pH alcalino. Rim101p se procesa proteolíticamente mediante un corte que elimina alrededor de 70 residuos del extremo C-terminal, llevado a cabo por la proteasa Rim13p, homóloga en S. cerevisiae de PalB (Futai et al., 1999). A pH ácido coexisten las formas procesada y no procesada de Rim101p, predominando ésta última, mientras que a pH neutro o alcalino únicamente se observa la forma procesada (Li \& Mitchell, 1997). La ausencia de Rim101p ocasiona problemas de crecimiento a pH alcalino, suponiendo este fenotipo la principal evidencia de la implicación de la ruta en la adaptación a este pH (Lamb et al., 2001).

Gracias a ensayos llevados a cabo con arrays se han podido identificar 71 genes que se sobreexpresan en condiciones alcalinas y están involucrados en múltiples procesos 
celulares (Lamb et al., 2001). Entre ellos cabe destacar la presencia de genes que codifican transportadores de metales y proteínas relacionadas con el metabolismo del fosfato, así como ENA1. Los genes cuya expresión aumenta a pH 8 pueden ser clasificados en tres grupos: aquéllos cuya expresión depende totalmente de RIM101 (como ARN4, YAR068W/YHR214W y ZPS1), otros cuya dependencia es tan sólo parcial (ENA1 y NRG2), y por último los que son independientes de este factor de transcripción (PHO11/12, PHO84, FRE1 y CTR3). Esto confirma, por un lado, la relación existente entre la ruta RIM101 y la regulación del pH, y por otro, la existencia de una respuesta al pH alcalino adicional a esta ruta.

Posteriormente se confirmó que la expresión de determinados genes frente a $\mathrm{pH}$ alcalino es también dependiente de la ruta de la calcineurina (Serrano et al., 2002). En concreto, la inducción de PHO89 a pH alcalino es totalmente dependiente de la ruta de calcineurina, y no se produce en ausencia del factor de transcripción CRZ1 o durante un tratamiento con la droga FK506 (inhibidor de la calcineurina). En el caso de ENA1, esta ruta del calcio media la respuesta alcalina de ENA1 de forma parcial. Por otro lado, otra vía que media en la respuesta alcalina es la ruta PKC, interviniendo en esta señalización la proteína sensora Wsc1p (Serrano et al., 2006).

Estudios posteriores han servido para confirmar que en S. cerevisiae Rim101p actúa fundamentalmente como represor transcripcional (Lamb \& Mitchell, 2003). Este factor de transcripción puede unirse in vivo directamente a la secuencia consenso TGCCAAG presente en los promotores de los genes sobre los que ejerce un control transcripcional negativo de forma directa; entre ellos se encuentra el gen RIM8. Sin embargo también es capaz de ejercer un papel como regulador positivo de la esporulación, crecimiento invasivo, tolerancia iónica y adaptación a pH alcalino mediante la represión de los represores transcripcionales NRG1 y SMP1. Por todo esto, se han encontrado varios genes que se sobreexpresan, y otros cuya expresión disminuye en el mutante rim101ム. La deleción de SMP1 suprime el defecto de crecimiento invasivo del mutante rim101A, mientras que la deleción de NRG1 elimina su sensibilidad al pH alcalino y a altas concentraciones de los cationes $\mathrm{Li}^{+}$y $\mathrm{Na}^{+}$. Estos hechos sugieren que a pesar de estar altamente conservadas, la ruta de señalización de $\mathrm{pH}$ de $A$. nidulans y la ruta RIM101 de $S$. cerevisiae difieren significativamente en su funcionamiento (Revisado en Penalva et al., 2008). 
El funcionamiento de la ruta RIM101 no sólo depende del factor de transcripción citado, sino de otras proteínas que forman también parte de la ruta (Figura 6) (Revisado en Penalva et al, 2008): la cisteín-proteasa de tipo calpaína Rim13p (homóloga de PalB en $A$. nidulans); Rim20p (PalA) involucrada en la activación de Rim101p mediante su interacción con ella; la proteína de tipo arrestina Rim8p (PalF); y las proteínas transmembrana Rim21p y Dfg16p (PalH), y Rim9p (Pall), que actuarían como sensores putativos. También se ha involucrado a Ygr122wp (PaIC), proteína de membrana plasmática poco caracterizada. Además de éstas, también son necesarias para el procesamiento de Rim101p diferentes subunidades de los complejos ESCRT-I (Vps23p, Vps28p y Vps37p), ESCRT-II (Vps36p, Snf8p, Vps25p) y ESCRT-IIIA (Vps20p y Snf7p) (Xu et al., 2004). Rim20p posee un dominio Bro1, gracias al cual ejerce como proteína adaptadora interaccionando con Snf7p y reclutando así el complejo ESCRT (Complejos de clasificación endosomal requeridos para el transporte) a los endosomas (Boysen \& Mitchell, 2006). Snf7p se une a su vez a las membranas de los endosomas directamente a través de interacciones con el complejo ESCRT-II y con Vps20p (del complejo ESCRT-III) (Babst et al., 2002; Lin et al., 2005; Teo et al., 2006). Otro posible componente de este módulo del endosoma sería Rim13p, una proteasa que interacciona de igual manera con Snf7p. Por último, Rim101p se reclutaría a este complejo gracias a Rim20p (Xu \& Mitchell, 2001; Vincent et al., 2003), pudiendo tener Rim20p un papel importante en la adecuada presentación de Rim101p a la proteasa Rim13p. Las subunidades de ESCRT que son necesarias para el procesamiento de Rim101p también lo son para el reclutamiento de Snf7p a los endosomas, mientras que las subunidades de ESCRT que no afectan a la localización de Snf7p, no se precisan por Rim101p para su procesamiento (Xu et al., 2004; Boysen \& Mitchell, 2006).

El modelo que se baraja actualmente situaría a las proteínas Rim21p, Dfg16p, $\operatorname{Rim} 9 p$ y Rim8p por encima del complejo endosomal, que contendría a $\operatorname{Rim} 13 p$ y $\operatorname{Rim} 20 p$, conectado al complejo ESCRT-III a través de Snf7p, al cual podría reclutarse Rim101p (Xu \& Mitchell, 2001; Hayashi et al., 2005). Por ello, para la señalización dependiente de pH, se sugiere la existencia de dos complejos, situados en la membrana plasmática y en los endosomas. La forma en que la señal se transmitiría desde los receptores de la membrana plasmática hasta el complejo endosomal, donde es posible que el factor de transcripción se procese, podría requerir de la proteína de tipo arrestina Rim8p para que se internalizara el complejo de membrana plasmática. 


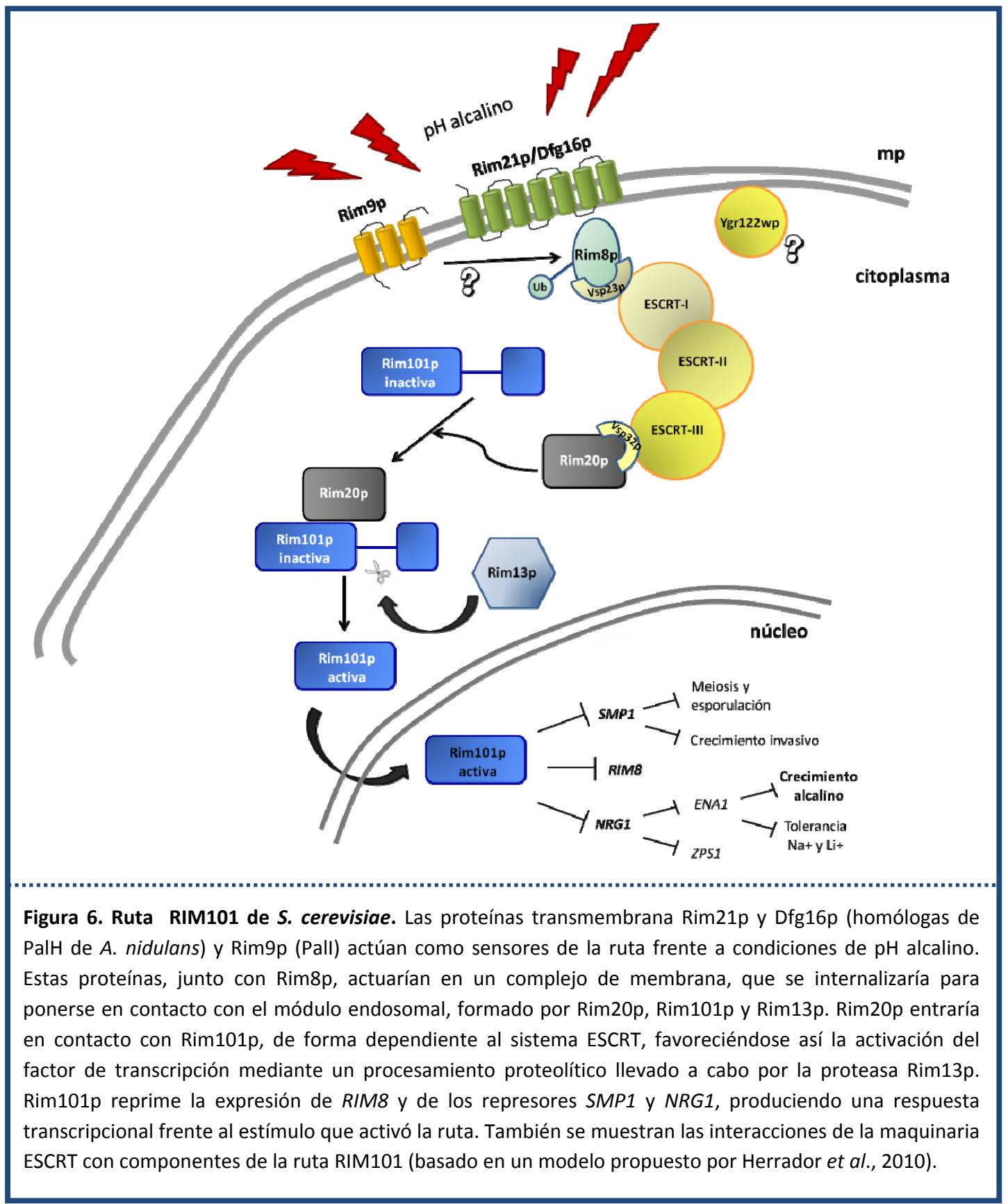

Recientemente se ha descrito que la proteína Rim8p se une tanto al sensor de 7 dominios transmembrana Rim21p, como a la subunidad Vsp23p del complejo ESCRT-I. La monoubiquitinación de Rim8p, llevada a cabo por la ubiquitín ligasa Rsp5p, y la existencia de un dominio SXP en Rim8p contribuyen en la interacción de esta proteína con el dominio UEV de Vsp23p (Herrador et al., 2010). Además Rim8p coinmunoprecipita tanto con Vsp23p como con Vsp28p (ESCRT-I), y Vsp28p y Rim8p, cuando son sobreexpresadas, colocalizan en 
estructuras punteadas en la membrana plasmática, apoyando la idea de que Rim8p sería una proteína adaptadora en el reclutamiento de la maquinaria ESCRT a una proteína de 7 dominios transmembrana (Rim21p y/o Dfg16p), mediando así en la internalización del complejo de sensores plasmáticos (Herrador et al., 2010) y en la eventual activación de la ruta. No se puede descartar que Ygr122wp, la gran desconocida hasta el momento, pueda ejercer una función similar.

La deleción de RIM101 en S. cerevisiae conduce a fenotipos como el ya descrito de hipersensibilidad frente a iones sodio y litio, al agente antifúngico fluconazol y a bajas temperaturas (Su \& Mitchell, 1993; Lamb \& Mitchell, 2003; Parsons et al., 2004). También es requerida para la adaptación y resistencia de la levadura frente a ácidos débiles a un pH constante 4.0 (Mira et al., 2009). De forma adicional, la ruta RIM101 se activa en respuesta a una alteración en la asimetría de los lípidos de membrana, imprescindible para una correcta fisiología de la misma, produciendo Rim101p un aumento en la expresión de RSB1 mediante la represión de NRG1 (Ikeda et al., 2008). Todo esto refuerza la idea de que RIM101 debe tener otros papeles adicionales a la respuesta inducida por el pH alcalino. En el contexto de esta memoria es también especialmente relevante la desregulación en la expresión de varios genes potencialmente implicados en el ensamblaje de la pared celular (Lamb et al., 2001).

\subsection{Ruta PKC}

\subsubsection{Activación de la ruta PKC}

La ruta de integridad celular, o ruta CWI (Cell Wall Integrity), es también conocida como ruta PKC, ya que la proteína Pkc1p es la encargada de promover la fosforilación del modulo de proteínas MAP quinasas. Éste incluye a la MAPKKK Bck1p, las MAPKK redundantes Mkk1p y Mkk2p y la MAP quinasa Slt2p, también conocida como Mpk1p (Revisado en Levin, 2005). La ruta se encuentra regulada durante el ciclo celular, aunque también se activa en respuesta a una gran variedad de estímulos externos que pueden ocasionar estrés sobre la pared celular y que serán descritos a continuación.

Durante el ciclo celular, se observa un pico máximo de activación de Slt2p durante la emergencia de la yema, al final de la fase G1 (Zarzov et al., 1996). Este aumento va unido 
a la polarización de los componentes de la ruta. De la misma manera se sabe que los cambios en la actividad de Cdc28p van asociados a cambios en la fosforilación de Slt2p (Marini et al., 1996; Zarzov et al., 1996). Sin embargo se desconoce cómo la actividad de Cdc28p regula la activación de la ruta.

El tratamiento con feromonas sexuales origina la parada en fase G1 de las células haploides y la emisión de una proyección de apareamiento, que coincide temporalmente con la máxima activación de esta ruta, lo que explica que los mutantes que carecen de la ruta PKC se lisen en presencia de estas feromonas (Errede et al., 1995). De igual manera la calcineurina también es imprescindible para la supervivencia celular durante el tratamiento con feromonas (Withee et al., 1997). Rho1p se localiza en la punta de la proyección de las células tratadas con feromonas (Bar et al., 2003), siendo reclutada por el complejo G $\beta \gamma$ de la ruta de respuesta a feromonas. Pkc1p posee la misma localización, siendo dependiente de la asociación de Rho1p con la subunidad G $\beta$ (Ste4p). Se ha descrito que para la activación de Slt2p frente a este estímulo son necesarias Pkc1p, Mkk1p y Mkk2p (Zarzov et al., 1996), mientras que Bck1p también lo es, pero tan sólo de manera parcial (Buehrer \& Errede, 1997).

Otro de los estímulos que activan la ruta es el choque térmico. Muchos de los mutantes que carecen de elementos de la ruta se lisan cuando se cultivan a temperaturas elevadas como $37-39^{\circ} \mathrm{C}$. Un aumento en la osmolaridad del medio suprime tanto la termosensibilidad como la lisis de los mutantes de esta ruta (Torres et al., 1991) al estabilizar la membrana plasmática en ausencia de una pared funcional estable. La fosforilación de Slt $2 p$ comienza 20 minutos tras la aparición del estrés y presenta su nivel máximo a los 30 minutos (Kamada et al., 1995), lo que sugiere que la ruta se activaría debido a un efecto secundario, como podría ser un aumento de la osmolaridad intracelular ocasionado por la acumulación de trehalosa en el citoplasma (Neves \& Francois, 1992), y que provocaría la activación de los sensores de la ruta. Esta activación desencadena finalmente la expresión de genes implicados en la biosíntesis de la pared celular (Kamada et al., 1995; Igual et al., 1996).

Son varios los agentes que afectan directamente a la pared celular, como el calcoflúor, la zimoliasa, las pneumocandinas o el rojo congo (Ketela et al., 1999; de Nobel et al., 2000; Reinoso-Martin et al., 2003). Todos ellos provocan una activación de esta ruta 
para reparar los daños sufridos en la pared (Garcia et al., 2004). Se ha podido verificar que la respuesta transcripcional frente al estrés ocasionado por la zimoliasa es debida a una cooperación entre la ruta PKC y la ruta HOG (Bermejo et al., 2008; Garcia et al., 2009). Otros compuestos como el ortovanadato o la cafeína también estimulan la ruta PKC, aunque probablemente mediante mecanismos diferentes. Además, muchas mutaciones que afectan a genes relacionados con la biosíntesis de la pared celular causan la activación constitutiva de la ruta (Lagorce et al., 2003). Muchos de los genes que se sobreexpresan en estas condiciones poseen en sus regiones regulatorias sitios para los factores de transcripción RIm1p, Swi4p (de la ruta PKC) y Crz1p (de la ruta $\mathrm{Ca}^{+2} /$ calcineurina), así como para Msn2p/4p y Hsf1p; por ello no es de extrañar la correlación existente entre la activación de las rutas $\mathrm{PKC}$ y $\mathrm{Ca}^{+2} /$ calcineurina bajo estas condiciones.

Hay que añadir a esto el estrés hipotónico, que origina una activación rápida y transitoria de la ruta (Davenport et al., 1995). Slt2p se activa tan sólo 15 segundos después del estímulo correspondiente, recuperándose la actividad basal tras 30 minutos. Igualmente se encuentran involucradas en esta respuesta las rutas HOG a través del sensor Sln1p y la ruta $\mathrm{Ca}^{+2} /$ calcineurina, mediando en la activación del factor de transcripción Crz1p (Li et al., 2002) .

La despolarización del citoesqueleto de actina mediada por el tratamiento con rapamicina, que inhibe específicamente a las quinasas Tor $1 p / 2 p$, o con latrunculina $B$ induce la activación de Slt2p (Harrison et al., 2001; Krause \& Gray, 2002). En esta respuesta son requeridas tanto Rho1p como Pkc1p, aunque existen diversas opiniones acerca del papel que juegan los sensores de la ruta. Unos afirman que Wsc1p o Mid2p son imprescindibles (Torres et al., 2002), mientras que otros le restan importancia a los mismos (Krause \& Gray, 2002). Estudios adicionales indican que los sensores no poseen una función en la respuesta a la latrunculina B (Harrison et al., 2001). Esta respuesta disminuye o se bloquea en presencia de un estabilizador osmótico, sugiriendo que estos compuestos originan un daño en la pared celular que desencadena la activación de la ruta. Cuando las células se encuentran sometidas a situaciones de estrés, el citoesqueleto de actina se deslocaliza y varias de las proteínas que forman parte de la ruta PKC cambian su distribución, movilizándose desde lugares de crecimiento polarizado hasta la periferia 
celular o regiones bajo esta superficie (Delley \& Hall, 1999), pudiendo intervenir así en la reparación del daño causado.

El estrés oxidativo también provoca la fosforilación de Slt2p. La peroxidación de lípidos podría ocasionar una oxidación de la membrana plasmática, originando una señal de estrés sobre la pared celular (Alic et al., 2003). Recientemente se ha descrito que Mtl1p actuaría como el sensor de la ruta PKC encargado de detectar el estrés oxidativo y activar la ruta a través de Rho1p (Petkova et al., 2010).

Además se ha podido comprobar que determinados mutantes de la ruta PKC presentan sensibilidad frente al $\mathrm{pH}$ alcalino del medio; asimismo el $\mathrm{pH}$ alcalino origina una activación rápida y transitoria de la ruta (Serrano et al., 2006). Posee aquí un papel fundamental el sensor Wsc1p, puesto que en su ausencia se disminuye la activación de Slt2p frente a la alcalinización del medio, y dicho mutante muestra sensibilidad alcalina. La expresión de varios genes relacionados con la pared celular se ve incrementada en respuesta a este estímulo, siendo dependiente de SIt2p. Los mutantes que carecen del SBF (factor de transcripción activado por la ruta PKC y formado por las proteínas Swi4p/Swi6p) son sensibles al pH alcalino, mientras que $r / m 1 \Delta$ es resistente, indicando que la tolerancia a este $\mathrm{pH}$ es dependiente del SBF e independiente de RLM1 (Serrano et al., 2006).

De forma general podría concluirse que es el estiramiento de la membrana lo que provoca la activación de esta ruta, habiéndose demostrado la relación entre su activación y la acumulación intracelular de $\mathrm{K}^{+}$(Merchan et al., 2004) o glicerol (Garcia-Rodriguez et al., 2005). Mucho más recientemente se ha demostrado que los sensores de la ruta actuarían siguiendo un modelo de muelle que reconocería la distancia física entre la membrana plasmática y la pared celular (Heinisch et al., 2010), lo que estaría de acuerdo con el modelo de estiramiento propuesto.

\subsubsection{Los componentes de la ruta PKC y su función en la respuesta}

\section{* Los sensores}

Se han descrito cinco proteínas transmembrana que actúan como sensores en la detección y transmiten el estado de la pared celular hacia Rho1p, activando así la ruta PKC (Figura 7). Son Wsc1p, Wsc2p, Wsc3p, Mid2p y Mtl1 (Revisado en Levin, 2005). 
Todas ellas contienen un extremo C-terminal citoplásmico pequeño, un único dominio transmembrana y un dominio periplásmico muy rico en residuos Ser/Thr que se encuentran altamente glicosilados (0-manosilados). Como hecho distintivo, las proteínas Wsc1-3p poseen una región característica en el dominio extracelular denominado dominio CRD (rico en cisteínas), ausente en Mid2p y Mtl1p. Las tres proteínas Wsc tienen gran similitud de secuencia entre ellas, mientras que Mid2p posee una identidad del 50\% con Mtl1p. Se ha propuesto que aquéllas que se han caracterizado con más detalle funcionan como mecanosensores, una hipótesis mucho más cercana hoy debido a los resultados recientemente obtenidos con el microscopio de fuerza atómica (Heinisch et al., 2010).

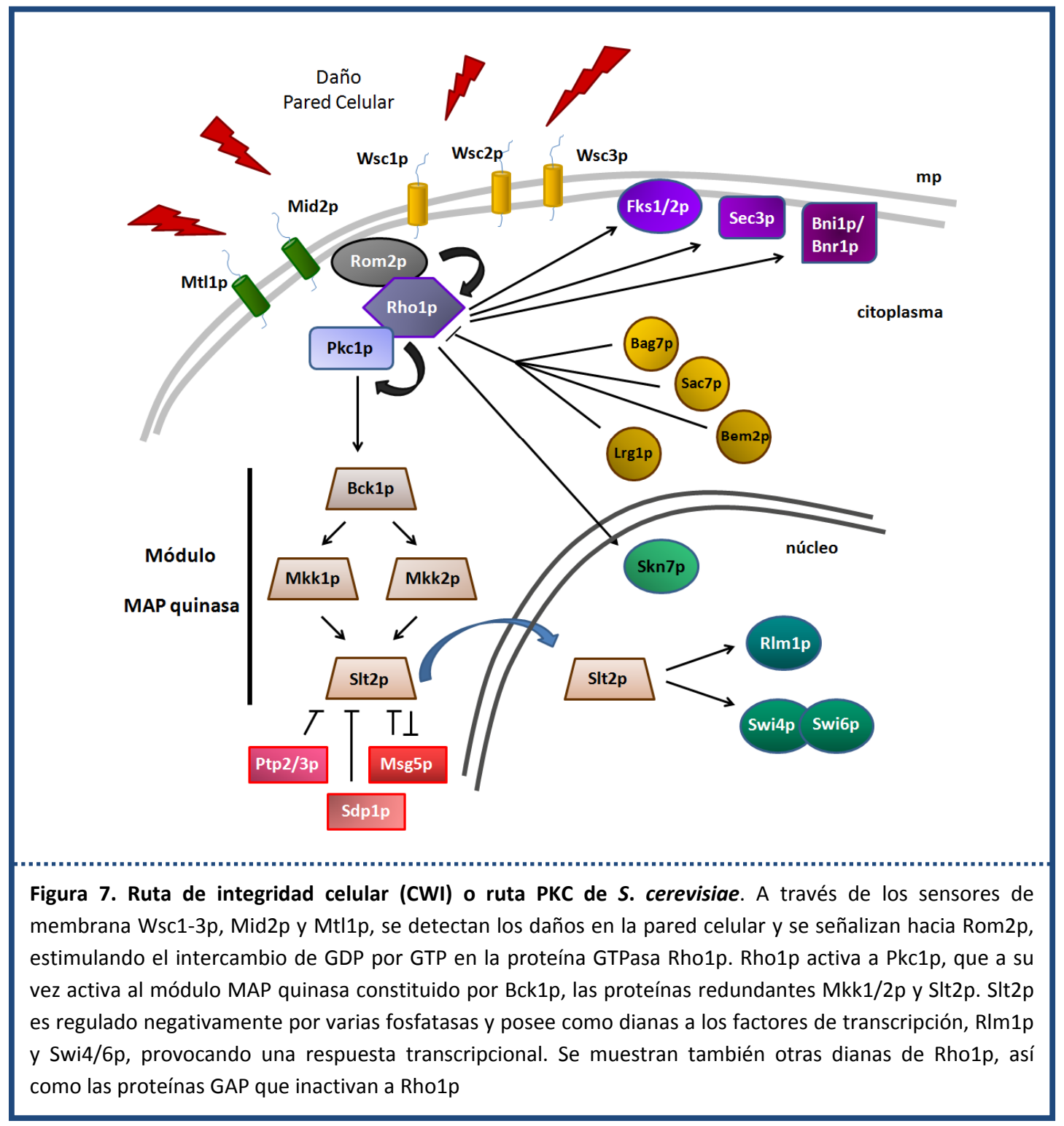


Wsc1p y Mid2p parecen ser los sensores del estrés de la pared celular más importantes, siendo necesaria al menos una de ellas para la supervivencia de la célula (Rajavel et al., 1999). Wsc1p se localiza en sitios de crecimiento polarizado (Delley \& Hall, 1999) y su deleción ocasiona la lisis celular a elevadas temperaturas, resultando además su presencia necesaria para la activación de Slt2p en estas condiciones (Verna et al., 1997). Por otro lado, Mid2p es necesaria para la activación de Slt2 $p$ en respuesta a feromonas, calcoflúor o elevadas temperaturas (Ketela et al., 1999) y es importante en el proceso de conjugación, siendo su localización en la periferia celular difusa y permitiendo que la señalización del estrés causado por las feromonas sea iniciado en cualquier punto de la superficie celular (Rajavel et al., 1999). La sobreexpresión de MID2 suprime la termosensibilidad de $w s c 1 \Delta$, y la sobreexpresión de WSC1 suprime la muerte ocasionada en mid2 $2 \Delta$ debido al tratamiento con feromonas, por lo que poseen un papel que se solapa parcialmente en la señalización de la ruta PKC (Ketela et al., 1999; Rajavel et al., 1999). Estudios recientes muestran que Mid2p es la principal implicada en la activación de la ruta por el rojo congo, mientras que Wsc1p lo es en respuesta a la caspofungina (Bermejo et al., 2010). Cabe destacar que en determinados casos existe una participación conjunta de diferentes rutas en respuesta a determinados tipos de estrés, como el causado frente a la zimoliasa, en el que colaboran las rutas PKC y HOG, teniendo el papel principal el sensor Sho1p de la ruta HOG, y donde carecen de importancia tanto Wsc1p como Mid2p (Bermejo et al., 2008).

\section{* La transmisión de la señal}

La GTPasa Rho1p fluctúa entre su estado activo, unido a GTP, y otro inactivo, unido a GDP. Ésta activa a Pkc1p cuando se encuentra en estado activo, además de regular otras respuestas como son la biogénesis de la pared celular, la organización del citoesqueleto de actina y la secreción polarizada (Revisado en Levin, 2005).

Existen cuatro proteínas GAPs (GTAase Activating Proteins), Bem2p, Sac7p, Bag7p y Lrg1p, que convierten Rho1p activo en inactivo. La regulación que lleva a cabo cada GAP sobre Rho1p es específica de la diana sobre la que actúa Rho1p. Por otro lado, las proteínas GEFs (Guanoside nucleotide Exchange Factors) Rom1p y Rom2p estimulan el paso de la forma inactiva de Rho1p a la forma activa, siendo probablemente Rom $2 p$ el principal intermediario en esta activación. El dominio amino terminal de Rom $2 p$ le permite 
interaccionar físicamente con las proteínas Wsc1p, Mid2p y posiblemente con otros sensores. Tus1p es una tercera GEF de Rho1p, de la que aún no se conoce con detalle su mecanismo de actuación. Además de la regulación de Rho1p ya mencionada, también intervendría la proteína Rdi1p, que es la única GDI (Rho-GDP Dissociation Inhibitor) de Rho1p en S. cerevisiae. Las proteínas GDI tienen la habilidad de extraer las proteínas Rho de las membranas, manteniéndolas en una forma inactiva en un complejo citosólico.

Al inicio de la activación de la ruta, Pkc1p se asocia a Rho1p-GTP (activa) y esto permite que pueda ser estimulada por la fosfatidilserina (pero no por otros cofactores como el diacilglicerol o el calcio, que convencionalmente activan PKCs en otros organismos) (Nonaka et al., 1995; Kamada et al., 1996). La deleción de Pkc1p es letal y es más grave que la de cualquier otro miembro de esta cascada por debajo de ella, lo que sugiere que regula múltiples rutas además de tener como papel más estudiado la activación del módulo MAPK

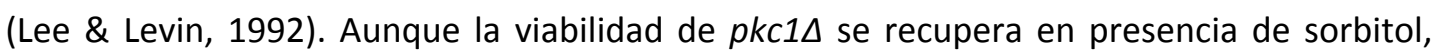
este mutante posee defectos en la pared celular, presentando una reducción de glucanos y mananos (Paravicini et al., 1992). Pkc1p posee un patrón de localización bastante similar al de Rho1p, situándose en sitios de crecimiento polarizado (Andrews \& Stark, 2000b), siendo requerido un anillo de septinas intacto para su localización en el cuello (Denis \& Cyert, 2005). Además, existe una pequeña cantidad de esta proteína que se ubica en el núcleo, pudiendo explicar esto el posible papel que podría desempeñar Pkc1p independiente a la ruta de integridad celular.

Pkc1p fosforila directamente a Bck1p in vitro en varios residuos. Bck1p fosforila a su vez a las proteínas Mkk1p/Mkk2p. Por último, Slt2p es activado cuando Mkk1p/Mkk2p la fosforilan de forma dual en los residuos Thr $^{190}$ y Tyr ${ }^{192}$ del motivo típico de MAPK T-X-Y (Irie et al., 1993; Kamada et al., 1995; Paravicini \& Friedli, 1996). La ausencia de cualquier quinasa aguas abajo de Pkc1p (o la ausencia simultánea de Mkk1p/Mkk2p) produce la lisis celular a elevadas temperaturas, siendo remediable en presencia de sorbitol. Las quinasas difieren en su localización en ausencia de estrés, ya que Bck1p y Mkk1/Mkk2p se encuentran en el citoplasma mientras que Slt2 tiene localización nuclear. Sin embargo, en caso de estrés sobre la PC, tanto Slt2p como Mkk1/Mkk2p se distribuyen en las zonas de crecimiento polarizado, algo que no se ha podido demostrar en el caso de Bck1p (Kamada et al., 1995; van Drogen \& Peter, 2002). Slt2p se localiza en cuello y en la punta de la yema, 
siendo independiente del citoesqueleto de actina, pero dependiente de Spa2p, ejerciendo esta última como proteína de andamiaje al interaccionar con Slt2p y las proteínas Mkk1p/Mkk2p (van Drogen \& Peter, 2002).

SIt2p se encuentra regulada negativamente por las fosfatasas Ptp2p, Ptp3p, Msg5p y Sdp1p, de las cuales tanto Msg5p como Ptp2p poseen una regulación recíproca por parte de Slt2p. La fosforilación de Msg5p provoca una disminución en la afinidad de unión por Slt2p, reduciendo la habilidad de Msg5p de inactivar a Slt2p (Flandez et al., 2004). Esto supone un excelente mecanismo de potenciación de la señal. Además, Msg5p actuaría manteniendo una actividad basal de Slt2p baja en ausencia de estrés. Algunas de estas fosfatasas actúan también sobre otras proteínas MAPK, como es el caso de Msg5p sobre Fus3p (Doi et al., 1994), o Ptp2p y Ptp3p sobre Hog1p y Fus3p (Mattison et al., 1999).

\section{* Los efectores}

Entre las dianas conocidas de Slt $2 p$ se encuentran los factores de transcripción RIm1p y el complejo SBF, las proteínas citosólicas Mih1p y Cch1p/Mid1p y las fosfatasas Msg5p y Sdp1p. Sin embargo todas las evidencias acumuladas sugieren la existencia de dianas adicionales.

RIm1p pertenece a la familia de los factores de transcripción MADS-box y es responsable de la gran mayoría de la respuesta transcripcional llevada a cabo por la ruta PKC, regulando, entre otros, la expresión de múltiples genes relacionados con la síntesis de la pared celular (Garcia et al., 2004). La "respuesta compensatoria" se lleva a cabo principalmente por RIm1p cuando se activa la ruta PKC debido a diversas situaciones de estrés (Garcia et al., 2004), provocando:

- un incremento en la cantidad de quitina y $\beta$-glucano;

- cambios en la asociación de los polímeros de la pared;

- un incremento en las proteínas de pared celular, así como un cambio en la localización de proteínas que intervienen en la síntesis de la pared celular lateral.

Esta proteína reside en el núcleo y su actividad aumenta cuando SIt2p la fosforila (Jung et al., 2002). Rlm1p tiene también como diana a MLP1, que codifica una pseusoquinasa homóloga a Slt2p y compite con ella por el acceso a Rlm1p o Mkk1p/Mkk2p 
(Watanabe et al., 1997). La deleción de RLM1 no origina fenotipos tan drásticos como los mostrados por s/t2L, lo que sugiere que deben existir funciones adicionales para Slt2p.

Durante el crecimiento vegetativo la pared celular debe remodelarse, lo que implica una coordinación entre la ruta PKC y el ciclo celular. Esto es llevado a cabo a través del SBF, un activador transcripcional formado por las proteínas Swi6p y Swi4p. Así se promueve tanto la expresión de genes relacionados con la biosíntesis de la pared celular como de genes involucrados en la transición G1/S (Breeden, 2003) y en la morfogénesis celular. Slt2p es capaz de fosforilar a SBF en respuesta a un estrés sobre la pared celular, aunque también se ha sugerido que SIt2p podría regular a SBF a través del ciclo celular (Madden et al., 1997; Baetz et al., 2001).

El hecho de que parte de la Slt2p nuclear se desplace hacia el citoplasma en respuesta frente a estrés sobre la pared celular, y exista una proporción de SIt2p en los lugares de crecimiento polarizado, sugería que existen dianas citoplasmáticas. Además se ha propuesto la posible implicación de Slt2p en la polarización del citoesqueleto de actina (Mazzoni et al., 1993).

Una de las proteínas citoplásmicas sobre las que podría actuar SIt2p es la fosfatasa Mih1p, que está involucrada en el ciclo celular regulando la fosforilación de Cdc28p (Sia et al., 1996). El checkpoint de morfogénesis, mediado por la fosforilación de Cdc28p, se activa cuando existe una despolarización del citoesqueleto de actina, dándose lugar a una parada en $\mathrm{G} 2$.

El canal de calcio de la membrana plasmática formado por Cch1p y Mid1p se activa frente a diversos estímulos (Locke et al., 2000), siendo SIt2p necesaria para esta activación en respuesta a estrés sobre el RE. Esto supone una de las interacciones existentes entre la ruta PKC y la ruta de señalización del calcio (Bonilla \& Cunningham, 2003).

No parece haber duda de que muchos de los efectores de esta ruta están aún por descubrir, lo que indicaría funciones adicionales para la ruta, algunas de las cuales probablemente sean independientes de la activación de la misma. 


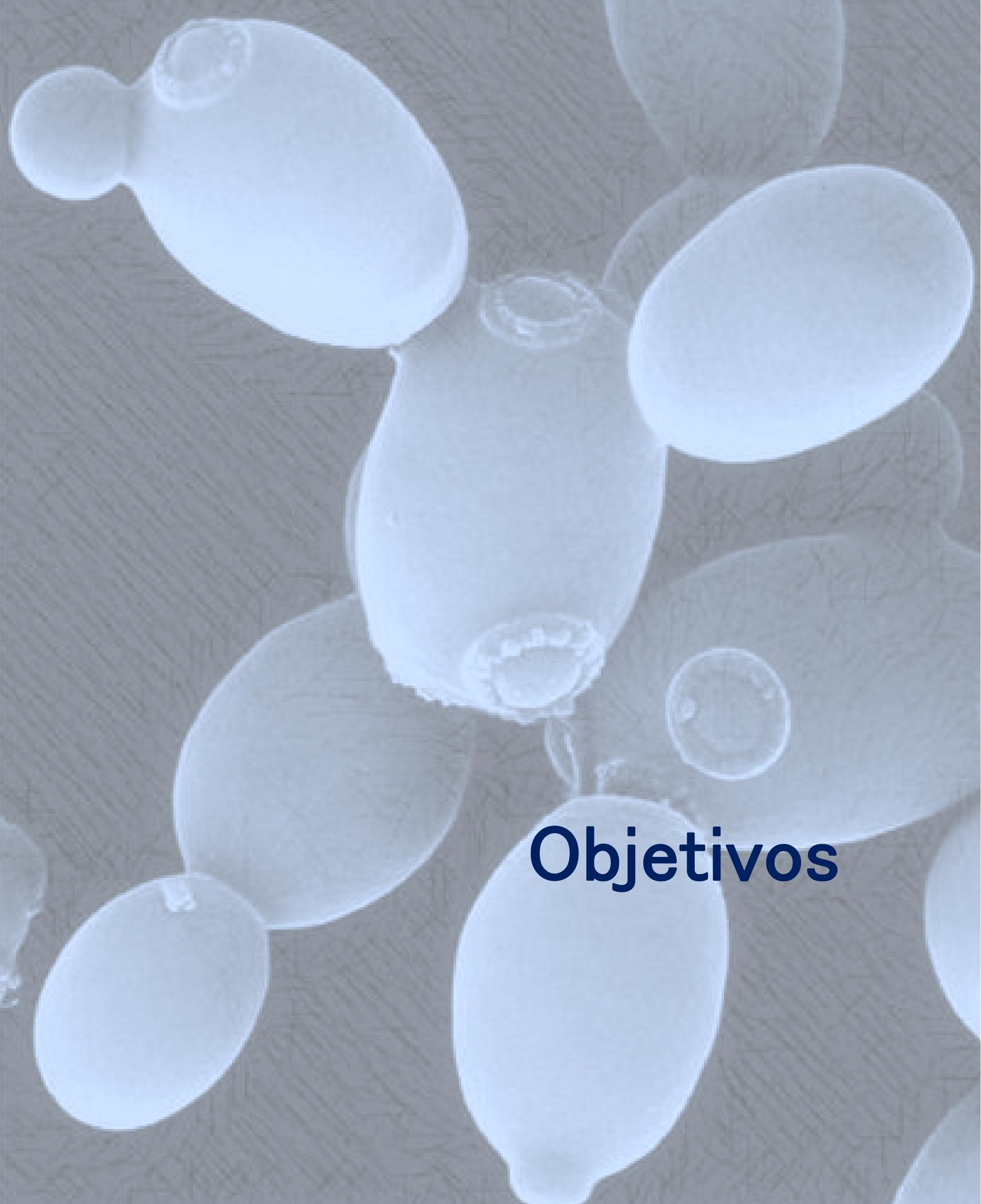



Previamente se habían identificado en nuestro grupo un conjunto de mutaciones de la ruta HOG que conferían resistencia a calcoflúor, lo cual llevó a una línea de trabajo basada en el estudio del papel que la ruta HOG pudiera desempeñar en el ensamblaje de la pared celular (Garcia-Rodriguez et al., 2000). Este trabajo condujo al estudio posterior de las relaciones entre esta ruta y la ruta de integridad celular (Garcia-Rodriguez et al., 2005).

Simultáneamente, nuestro grupo estuvo implicado en el proyecto EUROFAN II, lo

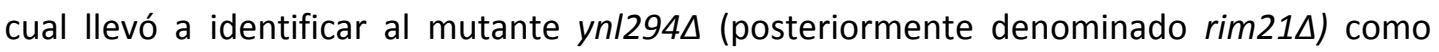
resistente a calcoflúor.

Por todo ello nos planteamos como objetivo principal de este trabajo esclarecer el papel que juega Rim21p, y por tanto la ruta RIM101, en la construcción de la pared celular de $S$. cerevisiae, y a partir de aquí, estudiar la posible relación que pudiera existir entre las rutas RIM101 y PKC en el mantenimiento de la integridad celular de este organismo. 





\section{MICROORGANISMOS UTILIZADOS}

Para la realización de este trabajo, se ha empleado la levadura de gemación $S$. cerevisiae. En la tabla 2 se muestran las cepas empleadas, así como su procedencia y características genéticas. Para los trabajos de clonación molecular se usaron las estirpes estándar de Escherichia coli DH5a y DH10B.

Tabla 2. Estirpes de S. cerevisiae empleadas en este trabajo

\begin{tabular}{|c|c|c|}
\hline Estirpe & Genotipo & Procedencia \\
\hline W303a & $\begin{array}{l}\text { MATa can1-100 ade2-1 his3-11,15 leu2-3,12 trp1-1 } \\
\text { ura3-1 }\end{array}$ & $\begin{array}{l}\text { Colección del } \\
\text { laboratorio }\end{array}$ \\
\hline W303 $\alpha$ & $\begin{array}{l}\text { MATa can1 -100 ade2-1 his3 -11,15 leu2-3,12 trp1-1 } \\
\text { ura3-1 }\end{array}$ & $\begin{array}{l}\text { Colección del } \\
\text { laboratorio }\end{array}$ \\
\hline BY4741 & MATa his $3 \Delta 1$ leu $2 \Delta 0$ met $15 \Delta 0$ ura3 $\Delta 0$ & Euroscarf \\
\hline FCM399 & BY4741 MATa rim21::URA3 & Este estudio \\
\hline FCM25 & W303 MATa rim21::URA3 & Este estudio \\
\hline FCM28 & W303 MATa rim21::kanMX4 & Este estudio \\
\hline FCM110 & W303 MATa s/t2::URA3 & Este estudio \\
\hline FCM323 & W303 MAT $\alpha$ rlm1::LEU2 & $\begin{array}{l}\text { Colección del } \\
\text { laboratorio }\end{array}$ \\
\hline FCM157 & W303 MAT $\alpha$ chs3::URA3 & $\begin{array}{l}\text { Colección del } \\
\text { laboratorio }\end{array}$ \\
\hline FCM159 & W303 rim21::kanMX4 chs3::URA3 & Este estudio \\
\hline FCM17 & W303 MATa pbs2::LEU2 & $\begin{array}{l}\text { Colección del } \\
\text { laboratorio }\end{array}$ \\
\hline FCM161 & W303 rim21::kanMX4 pbs2::LEU2 & Este estudio \\
\hline FCM111 & W303 MAT $\mathrm{fks} 1:: U R A 3$ & $\begin{array}{l}\text { Colección del } \\
\text { laboratorio }\end{array}$ \\
\hline FCM153 & W303 rim21::kanMX4 fks1::URA3 & Este estudio \\
\hline FCM165 & W303 MATa mid2::kanMX4 & $\begin{array}{l}\text { Colección del } \\
\text { laboratorio } \\
\end{array}$ \\
\hline FCM167 & W303 rim21::URA3 mid2::kanMX4 & Este estudio \\
\hline FCM319 & W303 MATa wsc1::kanMX4 & $\begin{array}{l}\text { Colección del } \\
\text { laboratorio }\end{array}$ \\
\hline FCM382 & W303 rim21::URA3 wsc1::kanMX4 & Este estudio \\
\hline FCM236 & W303 s/t2::URA3 rim21::kanMX4 & Este estudio \\
\hline FCM314 & W303 MATa rim101::kanMX4 & Este estudio \\
\hline FCM328 & W303 MATa s/t2::URA3 rim101::kanMX4 & Este estudio \\
\hline FCM386 & W303 rim21::kanMX4 rlm1::LEU2 & Este estudio \\
\hline
\end{tabular}




\begin{tabular}{|c|c|c|}
\hline FCM625 & BY4741 MATa rim8::natMX4 & Este estudio \\
\hline FCM609 & BY4741 MATa rim9::natMX4 & Este estudio \\
\hline FCM611 & BY4741 MATa rim13::natMX4 & Este estudio \\
\hline FCM613 & BY4741 MATa dfg16::natMX4 & Este estudio \\
\hline FCM615 & BY4741 MATa rim20::natMX4 & Este estudio \\
\hline FCM638 & BY4741 MATa rim21::natMX4 & Este estudio \\
\hline FCM640 & BY4741 MATa rim101::natMX4 & Este estudio \\
\hline FCM660 & W303 s/t2::URA3 rim8::natMX4 & Este estudio \\
\hline FCM662 & W303 slt2::URA3 rim9::natMX4 & Este estudio \\
\hline FCM664 & W303 slt2::URA3 rim13::natMX4 & Este estudio \\
\hline FCM666 & W303 slt2::URA3 dfg16::natMX4 & Este estudio \\
\hline FCM668 & W303 s/t2::URA3 rim20::natMX4 & Este estudio \\
\hline FCM670 & W303 s/t2::URA3 rim21::natMX4 & Este estudio \\
\hline FCM672 & W303 slt2::URA3 rim101::natMX4 & Este estudio \\
\hline FCM389 & W303 rim101::kanMX4 rlm1::LEU2 & Este estudio \\
\hline FCM391 & BY4742 MATa smp1::kanMX4 & Euroscarf \\
\hline FCM400 & BY4741 rim21::URA3 smp1::kanMX4 & Este estudio \\
\hline CRM872 & W303 MATa chs3::LEU2 & $\begin{array}{l}\text { Colección del } \\
\text { laboratorio }\end{array}$ \\
\hline FCM421 & W303 slt2::URA3 rim101::kanMX4 chs3::LEU2 & Este estudio \\
\hline CRM718 & W303 MATa cts1::hphMX4 & $\begin{array}{l}\text { Colección del } \\
\text { laboratorio }\end{array}$ \\
\hline FCM418 & W303 s/t2::URA3 rim101::kanMX4 cts1::hphMX4 & Este estudio \\
\hline FCM432 & W303 MATa ace2::hphMX4 & F. del Rey \\
\hline FCM439 & W303 s/t2::URA3 rim101::kanMX4 ace2::hphMX4 & Este estudio \\
\hline CRM1098 & W303 MAT $\alpha$ chs4::CHS4-GFP & $\begin{array}{l}\text { Colección del } \\
\text { laboratorio }\end{array}$ \\
\hline FCM506 & W303 MATa rim101::kanMX4 chs4::CHS4-GFP & Este estudio \\
\hline FCM507 & W303 MATa slt2::URA3 chs4::CHS4-GFP & Este estudio \\
\hline FCM546 & W303 MATa rsb1::kanMX4 & Este estudio \\
\hline FCM548 & W303 rsb1::kanMX4 slt2::URA3 & Este estudio \\
\hline FCM443 & W303 MATa prb1::natMX4 & Este estudio \\
\hline FCM447 & W303 rim101::kanMX4 prb1::natMX4 & Este estudio \\
\hline FCM503 & W303 slt2::URA3 rim101::kanMX4 prb1::natMX4 & Este estudio \\
\hline
\end{tabular}

\section{MEDIOS Y CONDICIONES DE CULTIVO}

Los medios específicos que se utilizaron a lo largo del trabajo son los que se describen a continuación. A partir de ellos se elaboraron los correspondientes medios 
sólidos añadiendo agar a una concentración final del $2 \%$. Todos los medios fueron preparados con agua desionizada (Milli-Rho) y esterilizados en el autoclave.

\subsection{Medios de cultivo para S. cerevisiae}

\subsubsection{Crecimiento vegetativo}

Los medios de cultivo utilizados para el crecimiento y mantenimiento de $S$. cerevisiae fueron los siguientes:

- Medio rico (YEPD): extracto de levadura al $1 \%$, peptona al $2 \%$ y glucosa al $2 \%$.

- Medio mínimo (YNB): base nitrogenada sin aminoácidos al $0.7 \%$ y glucosa al $2 \%$.

- Medio Sintético Definido (Medio SD): Medio mínimo suplementado con una mezcla de aminoácidos proteinogénicos y otros nutrientes. Con el fin de mantener la presión selectiva durante el crecimiento de las cepas transformadas con plásmidos, se empleó una mezcla comercial de aminoácidos (BIO 101 Systems) sin el suplemento correspondiente.

Cuando fue necesario, los medios empleados para el crecimiento de $S$. cerevisiae fueron suplementados con sorbitol, utilizado como estabilizador osmótico, y añadido de forma previa a la esterilización del medio de cultivo a una concentración 1M.

De igual manera, la glucosamina se añadió a una concentración final 15mM a partir de una solución 0.8M previamente esterilizada en el autoclave.

Para los ensayos de inducción del promotor GAL1, las células transformadas con el plásmido correspondiente se incubaron en medio SD selectivo con galactosa al $2 \%$ como fuente de carbono. Cuando se realizaron los ensayos de gota, se recogieron las células cultivadas en estas condiciones en fase logarítmica, y tras ajustarlas en agua Milli-Q a $\mathrm{DO}_{600}$ $=1$, se depositaron sobre placas del medio sólido correspondiente con galactosa al $2 \%$ como fuente de carbono, permitiéndose así la expresión del gen bajo el control del promotor GAL1, y se usaron como control placas con glucosa al $2 \%$. 


\subsubsection{Medios de selección de resistencia a antibióticos}

Cuando se necesitó seleccionar clones resistentes a antibióticos, las placas de medio sólido se suplementaron con sulfato de geneticina (G418, de GIBCO) a una concentración final de $200 \mu \mathrm{g} / \mathrm{ml}$ en placas de YEPD y $150 \mu \mathrm{g} / \mathrm{ml}$ en placas de SD; higromicina B (Roche) a $300 \mu \mathrm{g} / \mathrm{ml}$ o ClonNAT (Werner Bioagents) a $300 \mu \mathrm{g} / \mathrm{ml}$.

\subsubsection{Conjugación y esporulación}

Para inducir la conjugación entre cepas haploides de tipo sexual a y $\alpha$, se depositaron conjuntamente cepas de los dos tipos sexuales sobre una gota de agua en placas de YEPD. Tras una incubación de 12-24 horas a $28^{\circ} \mathrm{C}$, se seleccionaron las células diploides reestriándolas en placas de medio selectivo con las auxotrofías o resistencias al antibiótico correspondientes.

Una vez obtenidas las cepas diploides de interés, se inocularon en medio YEPD hasta una $\mathrm{DO}_{600} \approx 1.5-2$, y tras dos lavados con agua estéril y uno con Medio de esporulación (Acetato potásico al $1 \%$, y adenina al $0.01 \%$ ) se transfirieron a este medio, incubándose en matraces con buena aireación a 25C entre tres y cuatro días. Transcurrido este tiempo y una vez que el cultivo se encontraba con un buen porcentaje de células esporuladas, se recogieron las células contenidas en $500 \mu \mathrm{l}$ de cultivo, se resuspendieron en agua estéril y tras un tratamiento previo con glusulasa (PerkinElmer) al 1\% durante 5-10 minutos a $37{ }^{\circ} \mathrm{C}$, se procedió a la disección de las ascas con la ayuda de un micromanipulador automático (Singer Instruments MSM System Series 200) sobre placas de YEPD. Para ello se extendieron $10 \mu \mathrm{l}$ de la suspensión de esporas en un extremo de la placa y se recogieron ascas, separando las cuatro esporas de cada asca y depositándolas en zonas de la misma placa libres de células. Una vez que las esporas habían germinado y crecido durante 2-3 días, se seleccionaron los clones mediante réplicas en el medio selectivo correspondiente.

En ocasiones la presencia de sorbitol $1 \mathrm{M}$ o glucosamina $15 \mathrm{mM}$ fue necesaria en las placas de medio sólido para permitir la conjugación y el crecimiento de los mutantes sintético letales. 


\subsubsection{Medios suplementados con otros compuestos para ensayos de resistencia-sensibilidad}

El ensayo de resistencia a calcoflúor (Fluorescent Brightener 28, Sigma) se hizo en placas de YEPD o SD suplementadas con este antifúngico a la concentración final indicada (0-1 mg/ml). Cuando el medio empleado era SD, se tamponó con biftalato potásico 50mM, pH 6.2, para evitar la precipitación del fluorocromo.

El ensayo de resistencia a SDS se realizó en placas de YEPD o SD a una concentración final entre $0-0.05 \%$ cuando se trabajó con el fondo genético BY4741, o 0$0.005 \%$ en el caso del fondo genético W303, ya que se ha demostrado la influencia de la mutación trp1 en la sensibilidad a este compuesto (Gonzalez et al., 2008). En los ensayos de resistencia a cafeína, la concentración final empleada fue entre 0-5mM.

El ensayo de crecimiento frente a diferentes pH se llevó a cabo en placas de YEPD, al que se añadió tampón citrato o tampón fosfato a una concentración final $0.1 \mathrm{M}$ para ajustar dicho medio en los rangos de pH 4-6 ó 6-8 respectivamente. Para determinar la sensibilidad frente a $\mathrm{NaCl}$, se suplementaron las placas de YEPD con cloruro sódico a diferentes concentraciones comprendidas entre 0-1M.

La resistencia en placa se realizó siempre mediante el denominado ensayo de gota. Las células incubadas en el medio YEPD o SD adecuado fueron recogidas en fase logarítmica y se ajustaron en un mililitro de agua Milli-Q a una $\mathrm{DO}_{600} \approx 1$. Se hicieron diluciones seriadas $1 / 10$, y con un replicador estéril se depositaron las gotas sobre las placas suplementadas con los compuestos indicados anteriormente.

El ensayo de sensibilidad frente a zimoliasa se realizó en medio líquido YEPD o SD. Se tomó el cultivo a ensayar en fase logarítmica y se diluyó hasta una $\mathrm{DO}_{600} \approx 0.005$ en medio líquido fresco con cantidades crecientes de Zimoliasa 100T (Seikagaku Corporation) (0-5 U) y se incubaron durante 16 horas a $28^{\circ} \mathrm{C}$. Transcurrido ese tiempo, se midió la $\mathrm{DO}_{600}$ de cada cultivo y se representaron los datos en escala logarítmica, referidos como porcentaje de crecimiento obtenido en ausencia de la mezcla enzimática. 


\subsection{Condiciones de crecimiento para S. cerevisiae}

Habitualmente el crecimiento de esta levadura se realizó en medio líquido o sólido a una temperatura de $28^{\circ} \mathrm{C}$, llevando a cabo los experimentos con cultivos en fase logarítmica temprana $\left(\mathrm{DO}_{600}<2\right)$, a no ser que se especifique lo contrario. De manera rutinaria se preparaba un preinóculo en medio líquido al que se permitía alcanzar la fase exponencial, y posteriormente se inoculaba el cultivo a analizar partiendo del preinóculo. Los cultivos líquidos se mantuvieron creciendo en matraces con una agitación de 250 rpm sin que el volumen del cultivo superara la cuarta parte del volumen del matraz.

El crecimiento en medio líquido se determinó midiendo la turbidez del cultivo mediante absorbancia a $600 \mathrm{~nm}$ en un espectrofotómetro SmartSpec ${ }^{\text {TM }}$ Plus Spectrophotometer (Bio-Rad). El número de células por mililitro se estimó mediante comparación con una recta patrón obtenida representando el número de células contadas en una cámara Thoma frente a la absorbancia a $600 \mathrm{~nm}\left(\mathrm{DO}_{600}=1\right.$ se corresponde aproximadamente con $1-2 \times 10^{7}$ células/ml).

El mantenimiento de las cepas se realizó por resiembras en placas de medio sólido, que se conservaron a $4 \stackrel{\circ}{ } \mathrm{C}$ entre 30 y 40 días. Las cepas se conservaron a -80 으 en glicerol al $15 \%$.

\subsection{Crecimiento de E. coli}

Las células de $E$. coli se cultivaron en medio LB líquido o sólido a 37ํㅡ. Este medio está compuesto por triptona al $1 \%$, extracto de levadura al $0.5 \%$ y $\mathrm{NaCl}$ al $1 \%$; $\mathrm{pH} 7.0$. Para la selección o propagación de clones portadores de plásmidos, el medio se suplementó con ampicilina a $100 \mu \mathrm{g} / \mathrm{ml}$.

Las diferentes cepas se conservaron a $-80 \circ \mathrm{C}$ en glicerol al $50 \%$.

Las células competentes $\mathrm{DH} 5 \alpha$ se generaron por los servicios generales del Instituto de Biología Funcional y Genómica siguiendo el protocolo descrito (Kushner, 1978). 


\section{TÉCNICAS GENERALES DE BIOLOGÍA MOLECULAR}

\subsection{Obtención de ADN}

La extracción de ADN plasmídico a partir de bacterias se realizó usando el método de la lisis alcalina (Zhou et al., 1990), en el que las células se rompen en presencia de una mezcla de $\mathrm{NaOH}$ y SDS. El ADN es precipitado posteriormente con etanol. Cuando se necesitaba ADN de mayor pureza o una mayor concentración, se utilizó el kit comercial Wizard ${ }^{\circledR}$ Plus SV Minipreps DNA Purification System (Promega).

\subsection{Tratamientos enzimáticos del ADN}

Todos los protocolos usados para manipular el ADN, así como su transformación en las diferentes cepas, se recogen en la literatura (Sambrook \& Russell, 2001).

Los principales tratamientos enzimáticos realizados fueron:

- Digestiones con endonucleasas de restricción.

- Ligación de diversos fragmentos de ADN mediante la ADN ligasa del fago T4.

- Creación de extremos romos utilizando el fragmento Klenow de la ADN polimerasa I de E. coli.

\subsection{Electroforesis del ADN en geles de agarosa}

El análisis de los fragmentos de ADN obtenidos por tratamiento con enzimas de restricción o amplificación por PCR se llevó a cabo mediante electroforesis en geles de agarosa (Agarosa D-1, Pronadisa) preparados a una concentración variable entre 0.7-1.5\% según el tamaño esperado de los fragmentos. Los geles se prepararon con tampón TAE $1 X$ (Tris-acético 40mM, EDTA 2mM, pH 7.5-7.8) y se añadió como agente intercalante del ADN bromuro de etidio a una concentración final de $0.5 \mu \mathrm{g} / \mathrm{ml}$. 
Para el aislamiento y purificación de los fragmentos de ADN a partir de geles de agarosa se utilizó el sistema Illustra GFX ${ }^{T M}$ PCR DNA and Gel Band Purification Kit (GE Healthcare).

\subsection{Reacción en cadena de la polimerasa (PCR)}

La amplificación de fragmentos de ADN mediante PCR se llevó a cabo en un termociclador My Cycler ${ }^{T M}$ Thermal Cycler (Bio-Rad).

La reacción requiere la desnaturalización del ADN molde, el anillamiento de los cebadores incorporados a la reacción y finalmente, la extensión de las hebras sintetizadas. En cada momento es imprescindible que la reacción se encuentre a una temperatura determinada. El número de ciclos, la temperatura de anillamiento ( $\mathrm{Tm}$ ) y el tiempo de extensión se modifican sobre el protocolo estándar de la reacción según los requerimientos:

Desnaturalización inicia 10 minutos a $94^{\circ} \mathrm{C}$

1) Desnaturalización del ADN 1 minuto a $90 \circ \mathrm{C}$

2) Anillamiento 1 minuto a $55 \circ \mathrm{C}$ 30 ciclos

3) Extensión 5 minutos a $72 \circ \mathrm{C}$

Extensión final 10 minutos a $72 \circ \mathrm{C}$

Las mezclas de reacción contenían: ADN molde en cantidad variable según fuera ADN plasmídico o genómico; una mezcla de dNTP (dATP, dTTP, dGTP, dCTP) a una concentración final 10mM; $1 \mu \mathrm{M}$ de cada uno de los dos oligonucleótidos; $0.25 \mathrm{U} /$ reacción de la polimerasa JumpStart REDAccuTaq ${ }^{\circledR}$ LA DNA Polymerase (Sigma), y el tampón de reacción suministrado por el proveedor. Los cebadores empleados en este trabajo fueron suministrados por la empresa Thermo. Sus secuencias y finalidad se encuentran descritos en el Anexo (Tabla S-1).

Los fragmentos de ADN obtenidos por PCR se clonaron directamente en el plásmido pGEM ${ }^{\circledR}$ T (Promega) cuando fue necesario. 


\subsection{Secuenciación de ácidos nucleicos}

La técnica usada se basa en la descrita por Sanger (Sanger et al., 1977), pero en este caso se emplearon dideoxinucleótidos marcados con fluorocromos y un láser capaz de reconocer cada uno de ellos. Se utilizó un secuenciador Abi prism ${ }^{\circledR} 3100$ Genetic Analyzer (Applied Biosystems). Las secuencias se importaron mediante el programa Chromas, que muestra el cromatograma de la reacción y la secuencia de ADN correspondiente. Todas las reacciones se llevaron a cabo en el servicio de secuenciación de ADN de la Universidad de Salamanca.

\subsection{Reemplazamientos génicos}

Para la construcción de cepas carentes de un gen determinado se empleó la técnica de reemplazamiento génico en un solo paso (Rothstein, 1983), basada en las propiedades de transformación integrativa de las moléculas lineales de ADN. La estrategia consiste en la construcción de un casete de interrupción en el cual la región codificante del gen de interés se sustituye por un marcador seleccionable en levaduras. En la mayoría de las ocasiones se utilizaron como marcadores seleccionables los genes de resistencia de los módulos kanMX4 (resistencia a geneticina) o natMX4 (resistencia a nourseotricina) (Goldstein \& McCusker, 1999). Los casetes empleados en este trabajo se construyeron mediante amplificación por PCR del marcador de selección (kanMX4 o natMX4) a partir de los plásmidos pUG6 y pAG25 respectivamente. Este marcador quedaba flanqueado en cada caso por las regiones 3' y 5' no codificantes del gen de interés (de aproximadamente $45 \mathrm{pb}$ cada una), que se encontraban contenidas en los oligonucleótidos empleados para amplificar el marcador de selección. Estas regiones no codificantes permitían la integración del casete en el lugar de interés del genoma mediante recombinación homóloga. Los transformantes obtenidos se analizaron mediante PCR con oligonucleótidos que permitieran comprobar que dicha integración se había producido en el locus correspondiente. 


\subsection{Vectores utilizados}

\subsubsection{Vectores de E.coli}

pGEM $^{\circledR}$ T (Promega): Es un vector derivado del plásmido pGEM-5f(+) que se comercializa linearizado con una timidina adicional en los extremos, facilitando la inserción de fragmentos generados por PCR.

\subsubsection{Vectores de S. cerevisiae}

Los vectores de $S$. cerevisiae empleados en este trabajo son los de la serie pRS310: pRS313, pRS314, pRS315, pRS316 (Sikorski \& Hieter, 1989), que poseen los marcadores de selección: HIS3, TRP1, LEU2 Y URA3 respectivamente. Cada uno de los plásmidos de esta serie contiene una secuencia de replicación autónoma ARS4 y una secuencia centromérica CEN6, que les confiere estabilidad mitótica y meiótica en bajo número de copias (1-2 por cada célula) y capacidad de replicación autónoma.

Los plásmidos de la serie pRS420 (Christianson et al., 1992), comparten la misma secuencia que los pRS310, conteniendo además un origen de replicación del plásmido $2 \mu$ de $S$. cerevisiae, por lo que se mantienen en alto número de copias en la levadura (entre 20 y 30 por cada célula). Los plásmidos de esta serie se han utilizado para los experimentos de sobreexpresión. Asimismo se ha empleado para experimentos de sobreexpresión el plásmido YEp352, un vector episomal que contiene también el origen de replicación del plásmido $2 \mu$ y el marcador de selección URA3 (Hill et al., 1986).

La genoteca de sobreexpresión empleada en el escrutinio realizado en el estudio se encuentra construida en el plásmido YEp13 (ATCC 37323), que contiene el origen de replicación del plásmido $2 \mu$ y el marcador de selección LEU2.

De forma general, el gen indicado se expresa en todos los plásmidos a partir de su propio promotor. En los plásmidos que se indican en la tabla 3, el promotor propio del gen ha sido reemplazado por el promotor inducible del gen GAL1.

Los plásmidos empleados en este trabajo se muestran en la tabla 3. 
Tabla 3. Plásmidos utilizados en este trabajo

\begin{tabular}{|c|l|l|}
\hline Nombre & \multicolumn{1}{|c|}{ Descripción } & \multicolumn{1}{|c|}{ Procedencia } \\
\hline FCM494 & pRS424-CCT7 & Este estudio \\
\hline FCM493 & YEp13-GFA1 & Este estudio \\
\hline FCM492 & pRS425-PCL1 & Este estudio \\
\hline FCM574 & pRS426-KSS1 & Este estudio \\
\hline FCM427 & pRS314-RIM101 & Este estudio \\
\hline FCM426 & pRS424-RIM101 & Este estudio \\
\hline FCM406 & pRS322-ACT1 & P. San Segundo \\
\hline FCM415 & YEp352-CTS1 & F. del Rey \\
\hline FCM435 & pRS424-CHS1 & H. Valdivieso \\
\hline FCM430 & pRS315-ACE2-YFP & F. del Rey \\
\hline CRM1129 & pRS314-CHS3-GFP & Colección del laboratorio \\
\hline CRM768 & pRS314-CHS4-GFP & Colección del laboratorio \\
\hline CRM846 & pRS314-MYO1-GFP & Subclonado a partir de (Lippincott \& Li, 1998) \\
\hline CRM951 & pRS314-BNI4-YFP & Colección del laboratorio \\
\hline CRM874 & pRS314-CDC3-GFP & Subclonado a partir de (Caviston et al., 2003) \\
\hline FCM682 & YEp352-HOG1 & H. Valdivieso \\
\hline FCM684 & YEp352-FUS3 & H. Valdivieso \\
\hline FCM685 & YEp352-GAL1-KSS1 & H. Valdivieso \\
\hline FCM686 & YEp352-GAL1-KSS1(K42R) & H. Valdivieso \\
\hline CRM1084 & pRS315-CHS3-3xHA & Colección del laboratorio \\
\hline CRM640 & pRS315-CHS4-3 $\times H A$ & Colección del laboratorio \\
\hline FCM576 & pRS425-SPH1 & Este estudio \\
\hline FCM715 & pRS425-SPA2 & Subclonado a partir de (Sheu et al., 1998) \\
\hline FCM423 & YEp352-MLP1-IacZ & J. Arroyo (Garcia et al., 2009) \\
\hline
\end{tabular}

\section{TÉCNICAS MICROSCÓPICAS}

Toda la microscopía óptica se realizó en un microscopio Leica DMR XA equipado con un sistema de iluminación halógena y un equipo de fotografía digital Hamamatsu ORCA ER Digital Camera. Las observaciones se realizaron sobre preparaciones húmedas a partir de cultivos en medio líquido. 


\subsection{Microscopía de fluorescencia}

La observación de muestras con fluorescencia se realizó en el microscopio descrito anteriormente mediante la iluminación de las mismas con un sistema de epifluorescencia empleando una lámpara de mercurio de 100W y usando los filtros adecuados para permitir pasar la luz ultravioleta (UV) de una determinada longitud de onda, según los espectros de excitación-emisión propios de los fluorocromos utilizados. Las imágenes digitales obtenidas de esta manera se procesaron posteriormente con el programa Adobe PhotoShop CS3.

\subsubsection{Fluorescencia directa con GFP o YFP}

La proteína verde fluorescente (GFP) es un polipéptido de 238 aminoácidos procedente de la medusa Aequorea victoria que posee la capacidad de emitir luz verde cuando se excita con luz ultravioleta de una longitud de onda de $395 \mathrm{~nm}$. Por ello, basta con fusionar en fase la secuencia de ADN que codifica esta proteína con la del gen de la proteína objeto de estudio, y observar la expresión de esta proteína híbrida al microscopio de fluorescencia. La proteína YFP deriva de la GFP y emite fluorescencia amarilla cuando se excita a una longitud de onda de $514 \mathrm{~nm}$.

Para observar las proteínas marcadas con GFP/YFP, el medio fue siempre suplementado con adenina (50 mg/L) con el fin de suprimir la autofluorescencia celular. En el caso de que los cultivos se encontrasen en medio rico YEPD, las células se lavaron con agua previamente a la visualización.

\subsubsection{Tinción con calcoflúor}

El calcoflúor es un fluorocromo que se une preferentemente a polisacáridos con enlaces $\beta-(1,4)$ que forman estructuras fibrilares, como la celulosa o la quitina. Gracias a la capacidad que presenta para emitir fluorescencia azul cuando se excita con luz de $372 \mathrm{~nm}$, podemos visualizar las zonas donde se está sintetizando quitina de forma activa.

El calcoflúor se preparó en agua a una concentración de $10 \mathrm{mg} / \mathrm{ml}$. Para conseguir su total disolución, se añadieron unas gotas de $\mathrm{KOH} 10 \mathrm{~N}$. Se esterilizó mediante filtración y se almacenó a 4ํㅡ protegido de la luz. 
Sobre un cultivo líquido de células en fase logarítmica creciendo en YEPD, se añadió calcoflúor a una concentración final de $50 \mu \mathrm{g} / \mathrm{ml}$ y se incubó durante 2-3 horas en agitación a 28ํㅡ, observándose después las células en el microscopio con el filtro UV. En el caso de cepas portadoras de plásmidos, el preinóculo del cultivo se realizó en el correspondiente medio selectivo y en fase logarítmica se transfirieron las células a medio rico YEPD y se incubaron durante 30 minutos para permitir la adaptación al medio, añadiendo posteriormente el calcoflúor. El cambio de medio se realizó para evitar la precipitación del calcoflúor en medio SD, debido al pH del mismo.

Para la visualización precisa del anillo de quitina, se llevó a cabo una fijación de las células con formaldehído al 3.2\% durante media hora. Posteriormente se lavaron las células con agua estéril y se resuspendieron en agua, incubándolas con calcoflúor ( $50 \mu \mathrm{g} / \mathrm{ml}$ ) en agitación constante durante cinco minutos. Antes de observarlas al microscopio, las células se lavaron con agua.

\subsection{Microscopía electrónica de transmisión}

Para la preparación de las muestras, células de las diferentes cepas objeto de estudio se inocularon en medio rico YEPD suplementado con sorbitol $1 \mathrm{M}$. Posteriormente, se transfirieron durante 1.5 horas a medio YEPD, recogiéndose $12.5 \mathrm{ml}$ de estas células en fase logarítmica $\left(\mathrm{DO}_{600} \approx 1\right)$. A continuación se lavaron tres veces con agua y se fijaron con permanganato potásico al $2 \%$ durante una hora a temperatura ambiente. El exceso de permanganato potásico fue eliminado mediante sucesivos lavados con agua y las células fijadas se deshidrataron empleando concentraciones crecientes de etanol (70\%, $90 \%$ y $100 \%)$.

Las muestras se incluyeron posteriormente en resina mediante el kit comercial Spurr Resin Embedding (TAAB) mediante sucesivas incubaciones de dos horas con concentraciones crecientes de resina (usando mezclas $1: 1$ y $1: 3$ de etanol/resina), hasta incluir las muestras en resina pura. A continuación se concentraron las células en $500 \mu \mathrm{l}$ de resina y se introdujeron las muestras en cápsulas, incubándolas en una estufa a 70 으 durante 16 horas, permitiendo así la polimerización de la resina. 


\section{Materiales y Métodos}

Las secciones ultrafinas de las muestras se realizaron empleando un ultramicrotomo $L K B$ Ultratome III. Posteriormente, las rejillas generadas se fijaron con acetato de uranilo al $2 \%$ y citrato de plomo para darles contraste, y se observaron bajo el microscopio electrónico de transmisión Zeiss EM 900 del servicio de Microscopía Electrónica de la USAL. Las imágenes fueron procesadas con el software Adobe PhotoShop CS3.

\section{DETERMINACIÓN DE LA CANTIDAD DE QUITINA}

La valoración cuantitativa de quitina se llevó a cabo siguiendo el protocolo descrito (Bulawa et al., 1986). Para ello se recogieron $100 \mathrm{mg}$ de células en fase logarítmica, extrayéndose éstas con $1 \mathrm{ml}$ de $\mathrm{KOH}$ al $6 \%$ durante 90 minutos a $80^{\circ} \mathrm{C}$. Tras enfriar las muestras, se añadieron $100 \mu \mathrm{l}$ de ácido acético glacial para neutralizar el pH de la suspensión y se lavaron con agua hasta alcanzar pH neutro. A continuación se resuspendieron las células en $560 \mu \mathrm{l}$ de $\mathrm{NaPO}_{4} 50 \mathrm{mM}, \mathrm{pH} 6.3$, y se trataron con $40 \mu \mathrm{l}$ de quitinasa $(0.637 \mathrm{mU} / \mathrm{ml})$ de Serratia marcescens (Sigma). La reacción se incubó durante 2 horas a $37^{\circ} \mathrm{C}$ y para detenerla, se hirvieron las muestras durante un minuto. Finalmente, a $400 \mu \mathrm{l}$ de la reacción anterior se añadieron $25 \mu \mathrm{l}$ de glusulasa (PerkinElmer) y se incubó durante una hora a $37{ }^{\circ} \mathrm{C}$ para degradar los dímeros de quitina (quitobiosa), resultantes del tratamiento con quitinasa, a monómeros de NAcGln. Se detuvo la reacción hirviendo las muestras durante un minuto.

La cuantificación de NAcGln se realizó mediante el ensayo colorimétrico descrito

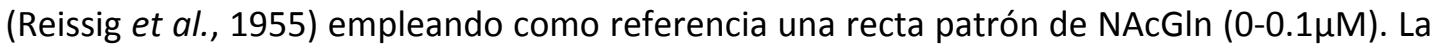
cantidad de quitina se expresa en nmoles de NAcGln/100 mg de células.

\section{DETECCIÓN DE ÁCIDOS NUCLEICOS}

\subsection{Preparación de sondas marcadas radiactivamente}

El marcaje radiactivo de los fragmentos de ADN empleados como sondas se llevó a cabo con el kit de marcaje Rediprime Random Prime Labelling System (GE Healthcare) siguiendo el protocolo aconsejado por la casa proveedora. En cada caso se marcaron $25 \mathrm{ng}$ 
de ADN lineal diluido en $45 \mu \mathrm{l}$ de TE $1 \mathrm{X}$ que se desnaturalizaron por calentamiento a $100 \stackrel{\circ}{ } \mathrm{C}$ durante 5 minutos y enfriamiento rápido en hielo durante 5 minutos antes de mezclarlo con el contenido liofilizado del tubo de reacción. Se añadieron $50 \mu \mathrm{Ci}$ de $\left[{ }^{32} \mathrm{P}\right]-\alpha$-dCTP y se incubó a $37^{\circ} \mathrm{C}$ durante 10 minutos, deteniéndose la reacción mediante la adición de $5 \mu$ l de EDTA 0.2M.

\subsection{Manipulación del ARN}

Para la obtención del ARN total se utilizó el método descrito (Sambrook et al., 1989). La valoración de la concentración del ARN en las muestras se efectuó midiendo la absorbancia a $260 \mathrm{~nm}$ y teniendo en cuenta la relación de absorbancia $260 \mathrm{~nm} / 280 \mathrm{~nm}$ para estimar el grado de pureza de la preparación. La cantidad se calculó teniendo en cuenta que una $A_{260}=1$ equivale a una concentración de $A R N$ de $40 \mu \mathrm{g} / \mathrm{ml}$ en solución acuosa. Para la obtención específica de ARNm se empleó el kit comercial Illustra ${ }^{T M} m R N A$ Purification Kit (GE Healthcare). Para la realización del Northern blot se cargaron $10 \mu \mathrm{g}$ de cada ARNm por carril, y se siguió la técnica que emplea formamida y formaldehído como agentes desnaturalizantes (Sambrook et al., 1989). Los ARN fueron transferidos por capilaridad a membranas Hybond ${ }^{T M}-N$ (GE Healthcare) y se fijaron a ella mediante exposición a luz UV (cámara Stratalinker 2400, Stratagene). Estas membranas se hibridaron con la sonda marcada radiactivamente (Ver apartado 6.1), y fueron visualizados mediante el uso de un equipo PhosphorImager BAS1500 System (Fujifilm). La intensidad de las bandas fue cuantificada y los valores están referidos siempre a la actina, empleándose ésta como control de carga. Para la hibridación secuencial de la membrana, la sonda radiactiva fue eliminada sumergiendo la membrana en SDS al $0.1 \%$ hirviendo.

\section{ANÁLISIS DE PROTEÍNAS}

\subsection{Obtención de extractos de proteínas}

Los extractos de proteínas se obtuvieron siguiendo el protocolo descrito (Sambrook et al., 1989). Para ello se recogieron mediante centrifugación $10 \mathrm{ml}$ de células en fase logarítmica, y después de lavarlas con tampón Tris $10 \mathrm{mM}, \mathrm{pH}$ 7.0, se congelaron inmediatamente en hielo seco y se guardaron a $-80^{\circ} \mathrm{C}$. Posteriormente se resuspendieron 
los precipitados celulares en 150-200 $\mu$ l de tampón de lisis (Tris- $\mathrm{HCl} 50 \mathrm{mM}, \mathrm{pH}$ 8.0, $\mathrm{NaCl}$ 150 mM y Tritón X-100 al 0.1\% (Sigma)) que contenía una mezcla de inhibidores de proteasas: PMSF $1 \mathrm{mM}$ (Sigma), aprotinina $1 \mu \mathrm{g} / \mathrm{ml}$ (Sigma), leupeptina $1 \mu \mathrm{g} / \mathrm{ml}$ (Sigma) y pepstatina $1 \mu \mathrm{g} / \mathrm{ml}$ (Sigma). Una vez identificados ciertos problemas técnicos que se encuentran descritos en el capítulo 5 de los resultados de esta memoria, se decidió emplear PMSF a una concentración mayor $(2 \mathrm{mM})$ y se evitó la congelación-descongelación de los precipitados celulares, siendo procesados directamente una vez lavados con Tris.

La suspensión resultante se cubrió con bolas de vidrio (B. Braun Biotech International de $0.45 \mathrm{~nm}$ de diámetro) y las muestras se rompieron en un agitador Fast Prep FP120 Bio 101 (Savant) en 2 intervalos de 30 segundos a una velocidad de $5.5 \mathrm{~m} / \mathrm{s}$. El lisado resultante se centrifugó a $13000 \mathrm{rpm}$ durante 5 minutos para eliminar los restos de células, paredes celulares y bolas de vidrio. Todo el proceso se realizó a 4드 y en hielo para evitar la degradación de las proteínas.

El sobrenadante se recogió y se cuantificó la concentración de proteína de los extractos usando el método colorimétrico descrito (Bradford, 1976) mediante el kit comercial Protein Assay Reagent (BioRad) y empleando albúmina de suero bovino, BSA (Sigma), para confeccionar la recta patrón.

A los extractos proteicos se les añadió el mismo volumen de tampón de carga $2 \mathrm{X}$ (Tris- $\mathrm{HCl} 0.1 \mathrm{M}, \mathrm{pH} 6.8$, SDS al 2\%, glicerol al 2\%, $\beta$-mercaptoetanol $0.7 \mathrm{M}$ y azul de bromofenol al $0.08 \%$ ) y se desnaturalizó durante 5 minutos a 100 ㄷ. Para la realización de geles de SDS-PAGE e inmunodetección se cargaron típicamente entre 25 y $30 \mu \mathrm{g}$ de proteína total (siempre la misma cantidad de proteína en el mismo experimento).

\subsection{Separación electroforética e inmunodetección}

Las proteínas se resolvieron por electroforesis en geles de poliacrilamida del $7.5 \%$ en condiciones desnaturalizantes (SDS al 1\%) a $150 \mathrm{mV}$ durante aproximadamente 1.5 horas, según la técnica descrita (Laemmli, 1970). La composición del tampón de carrera es: Tris base $6 \mathrm{~g} / \mathrm{L}$, SDS $2 \mathrm{~g} / \mathrm{L}$ y glicina $28.8 \mathrm{~g} / \mathrm{L}$. 
Las proteínas se transfirieron a membranas de PVDF (Immobilon-P, Millipore) mediante el sistema Mini-Trans-Blot ${ }^{\oplus}$ (Bio-Rad) durante 1-1.5 horas a $400 \mathrm{~mA}$, usando como tampón tris-glicina (tris base $3 \mathrm{~g} / \mathrm{L}$ y glicina $14.4 \mathrm{~g} / \mathrm{L}$ ).

Posteriormente las membranas se bloquearon en TBST (tris base $2.5 \mathrm{~g} / \mathrm{L}, \mathrm{NaCl} 9 \mathrm{~g} / \mathrm{L}$ y tween 20 al $0.3 \%$ (Sigma)) con leche al 5\% durante 1 hora a temperatura ambiente. Después se incubaron durante 60-90 minutos a temperatura ambiente con el anticuerpo primario diluido en solución de bloqueo. Las membranas se lavaron tres veces durante 10 minutos con TBST y se incubaron después con un anticuerpo secundario anti-IgG unido a peroxidasa de rábano (HRP) durante 1 hora. Tras esta incubación, las membranas se lavaron tres veces con TBST y se añadió el sustrato para la detección de la actividad peroxidasa por quimioluminiscencia siguiendo las instrucciones del kit ECL (GE Healthcare). Las proteínas reconocidas por los anticuerpos se detectaron utilizando películas Super $R X X$ Ray Film (Fujifilm).

Los anticuerpos primarios utilizados fueron:

- Anticuerpo monoclonal 12CA5 contra el epítopo HA (Roche Diagnostics), a una dilución 1:4000.

- Anticuerpo monoclonal anti GFP (Clontech), a una dilución 1:1000.

- Anticuerpo policlonal anti $\alpha$-tubulina (Sigma-Aldrich), a una dilución 1:1000.

Los anticuerpos secundarios empleados fueron:

- Anticuerpo policlonal anti-IgG de ratón unido a peroxidada de rábano (BioRad) a una dilución 1:5000.

- Anticuerpo policlonal anti-IgG de conejo unido a peroxidada de rábano (BioRad) a una dilución 1:5000.

\section{ENSAYO $\beta$-GALACTOSIDASA CUANTITATIVO}

Para realizar este ensayo, se recogieron cultivos de $50 \mathrm{ml}$ de células en fase logarítmica $\left(\mathrm{DO}_{600} \approx 1\right)$. Las células se lavaron una vez con agua y se resuspendieron en 250 $\mu \mathrm{l}$ de tampón de lisis (100 mM Tris- $\mathrm{HCl}$ pH 8.0, glicerol al 20\%, $1 \mathrm{mM} \beta$-mercaptoetanol) que contenían $12.5 \mu \mathrm{l}$ de PMSF $40 \mathrm{mM}$. Las células se rompieron con bolas de vidrio, tal y 
como se ha descrito en el apartado 7.1, y se añadieron al final $250 \mu$ adicionales de tampón de lisis. El lisado se centrifugó 15 minutos a 500g en frío. Se cuantificó la cantidad de proteína de las muestras mediante el ensayo descrito (Bradford, 1976).

A continuación los extractos se mezclaron en tubos de vidrio con tampón Z $\left(\mathrm{Na}_{2} \mathrm{HPO}_{4} 60 \mathrm{mM}, \mathrm{NaH}_{2} \mathrm{PO}_{4} 40 \mathrm{mM}, \mathrm{MgSO}_{4} 10 \mathrm{mM}, \mathrm{pH}\right.$ 7.0) de la siguiente forma:

- $50 \mu \mathrm{l}$ de extractos $+950 \mu \mathrm{l}$ de tampón $\mathrm{Z}$

- $100 \mu \mathrm{l}$ de extractos $+900 \mu \mathrm{l}$ de tampón Z

Las muestras se incubaron a $28^{\circ} \mathrm{C}$ durante 30 minutos. Transcurrido este tiempo se añadieron $200 \mu \mathrm{l}$ de ONPG (4 mg/ml en tampón Z) (Sigma) y se empezó a contar el tiempo hasta la detección de un color amarillo pálido, momento en el que se detiene la reacción añadiendo $500 \mu \mathrm{l}$ de $\mathrm{Na}_{2} \mathrm{CO}_{3} 1 \mathrm{M}$ recién preparado. Posteriormente se midió la $\mathrm{DO}_{420}$ de cada muestra. La actividad $\beta$-galactosidasa se expresa en nmoles de O-Nitrofenil- $\beta$-Dgalactopiranósido convertidos/minuto/mg de proteína.

\section{ANÁLISIS ESTADÍSTICO}

Con el objetivo de determinar si algunas diferencias eran estadísticamente significativas, se realizó el análisis de la varianza de una vía (ANOVA). Dependiendo del tipo de muestras a analizar, se usaron el test de Tukey para muestras del mismo tamaño y el método GT2 para muestras de tamaño diferente en las comparaciones múltiples. El método de Dunnett se utilizó en las comparaciones directas con un control y el test chi cuadrado para examinar diferencias entre proporciones. En todos los tests se considera que existe una diferencia significativa cuando $P<0.05$.

\section{ANÁLISIS DE LAS INTERACCIONES GENÉTICAS}

Para estudiar las interacciones genéticas negativas existentes entre diversos mutantes, se han utilizado el programa Osprey 1.2.0 y la base de datos DRYGIN. Osprey es una herramienta informática que permite la visualización y la manipulación de complejas redes de interacciones biológicas en diversos organismos. Permite construir representaciones gráficas con gran cantidad de datos en las que los genes mostrados 
presentan diferentes colores atendiendo a la función biológica que cumplen. La información se extrae de múltiples bases de datos entre las que se encuentran SGD y NCBI, y es posible seleccionar el tipo de experimento del que queremos obtener la información deseada. En nuestro caso nos centramos en el estudio de las interacciones genéticas de letalidad sintética y de defecto de crecimiento mostradas por la combinación de dos deleciones.

DRYGIN es una base de datos que proporciona la información obtenida a partir de los ensayos masivos realizados en el laboratorio del Dr. Charles Boone (Universidad de Toronto) (Koh et al., 2010). Esta aplicación permite el análisis y la visualización de las interacciones genéticas tanto positivas como negativas presentadas entre diversos mutantes de $S$. cerevisiae. De la misma manera, DRYGIN también permite integrar datos adicionales para asociar estas interacciones genéticas con información conocida sobre complejos proteicos, rutas conocidas e interacciones físicas.

\section{ANÁLISIS INFORMÁTICO DE LOS DATOS}

Tabla 4. Recursos informáticos empleados en este trabajo

\begin{tabular}{|l|l|}
\hline \multicolumn{1}{|c|}{ NOMBRE } & \multicolumn{1}{c|}{ UTILIDAD } \\
\hline Adobe Photoshop CS3 & Tratamiento de imágenes \\
\hline $\begin{array}{l}\text { SGD (Saccharomyces Genome Database) } \\
\text { http://www.yeastgenome.org }\end{array}$ & $\begin{array}{l}\text { Base de datos del genoma de S. } \\
\text { cerevisiae }\end{array}$ \\
\hline Chromas & $\begin{array}{l}\text { Visualización y edición de los } \\
\text { cromatogramas de las secuencias de } \\
\text { ADN }\end{array}$ \\
\hline DNAstar y DNAstrider & $\begin{array}{l}\text { Análisis de las secuencias de ADN y } \\
\text { proteínas; obtención de mapas de } \\
\text { restricción }\end{array}$ \\
\hline $\begin{array}{l}\text { Clusta/W } \\
\text { http://www.ebi.ac.uk/Tools/msa/clustalw2j }\end{array}$ & $\begin{array}{l}\text { Comparación de secuencias de ADN y } \\
\text { proteínas }\end{array}$ \\
\hline Osprey 1.2.0 & $\begin{array}{l}\text { Obtención de la red de interacciones } \\
\text { genéticas }\end{array}$ \\
\hline DRYGIN http://drygin.ccbr.utoronto.ca & $\begin{array}{l}\text { Base de datos de las interacciones } \\
\text { genéticas descritas en el laboratorio del } \\
\text { Dr. Charles Boone (Universidad de } \\
\text { Toronto) }\end{array}$ \\
\hline PubMed http://www.ncbi.nlm.nih.gov/pubmed & Búsqueda bibliográfica \\
\hline SPSS (Statistical Package for the Social Sciences ) & \begin{tabular}{l} 
Análisis estadístico \\
\hline
\end{tabular}
\end{tabular}







\section{RELACIÓN DE LA RUTA RIM101 CON LA PARED CELULAR}

\subsection{Caracterización fenotípica del mutante yn/2944}

Durante la participación de nuestro laboratorio en el proyecto EUROFAN II, basado en la construcción y caracterización de una colección de mutantes nulos de $S$. cerevisiae, se realizó una búsqueda masiva de mutantes viables con defectos asociados a la pared celular. Entre otros se identificó el mutante nulo yn/2944, que presentaba resistencia parcial a calcoflúor. Éste es un fluorocromo que se une preferentemente a polisacáridos con enlaces $\beta-(1,4)$ que forman estructuras fibrilares como la celulosa y la quitina. Su unión incrementa la tasa de síntesis de quitina en varios sistemas fúngicos, además de mostrar actividad antifúngica (Roncero \& Duran, 1985). El fenotipo de resistencia a calcoflúor en medio sólido que presentaba este mutante (Figura $\mathbf{8 A}$ ) está habitualmente ligado a la ausencia de actividad quitín sintasa III (QSIII), aunque éste no parecía ser el caso, ya que el mutante

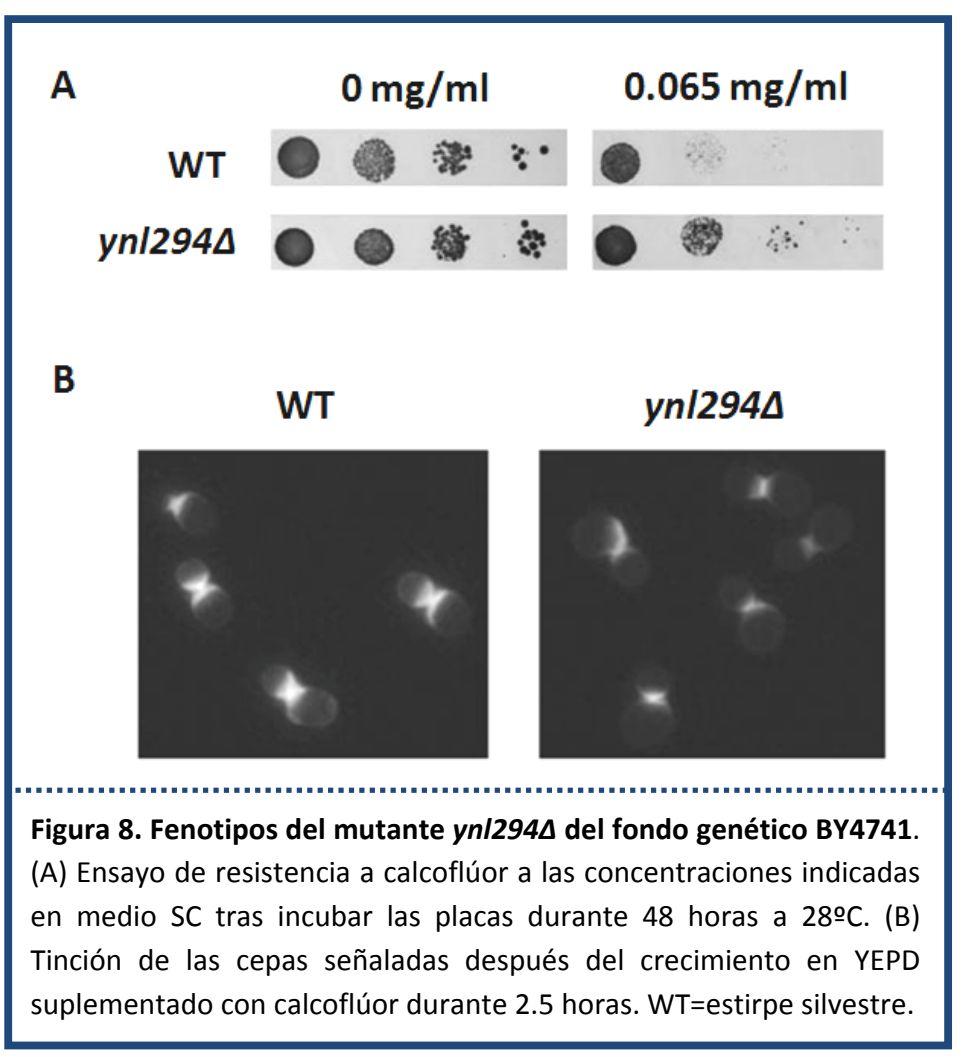

yn/2944 poseía niveles normales de esta actividad (de Groot et al., 2001). Esto nos llevó a investigar en detalle la causa de la resistencia de este mutante al calcoflúor.

Al cuantificar la cantidad de quitina presente en la levadura, observamos que, en condiciones normales de crecimiento, este mutante poseía unos niveles de este polímero similares a los de la estirpe silvestre (Tabla 5). Sin embargo, cuando las células de la cepa yn/2944 fueron tratadas con calcoflúor para determinar la localización celular de la quitina, se observó que, aunque se 


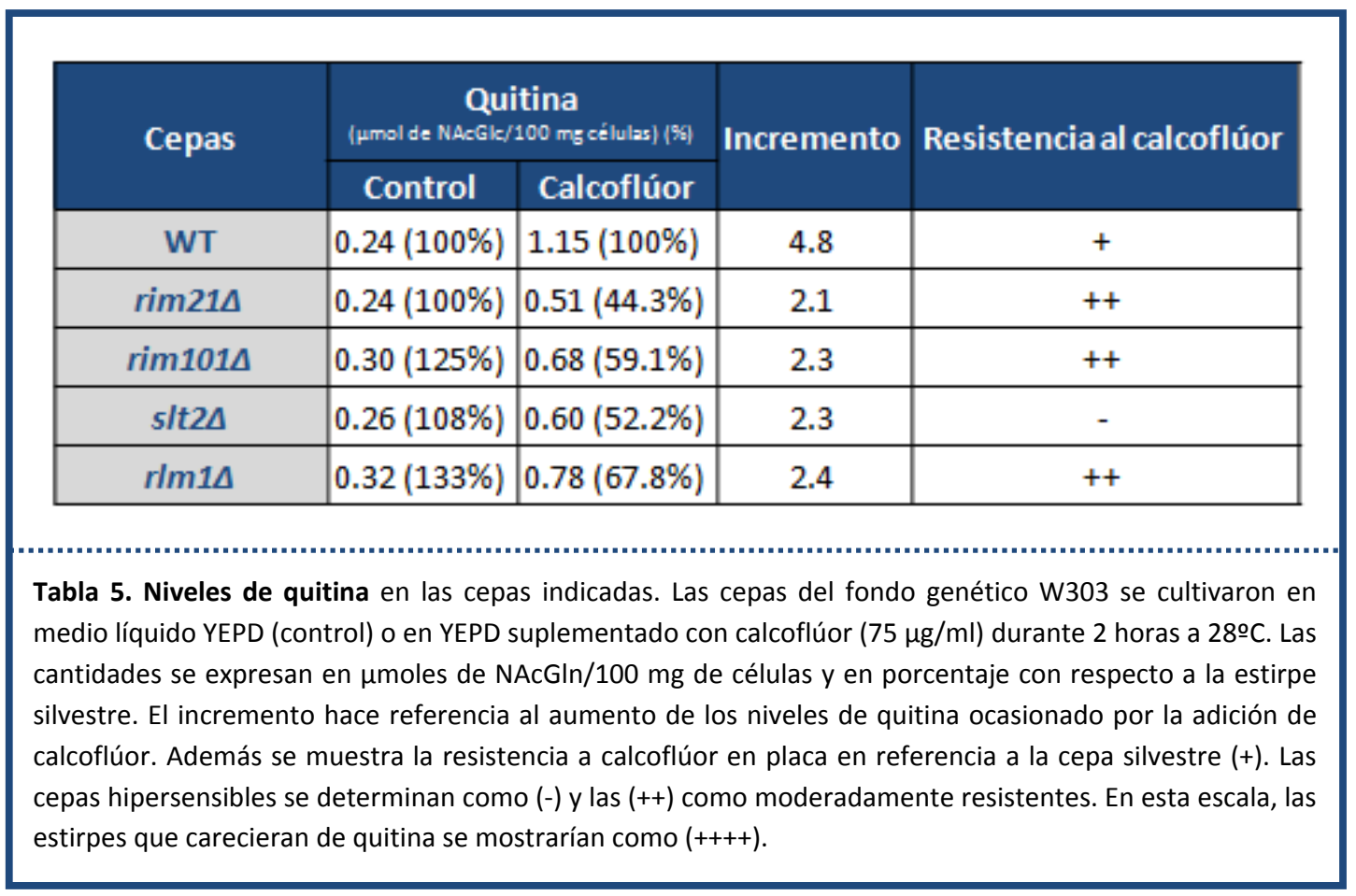

encontraba localizada en el septo, tal y como ocurre en la cepa silvestre, la intensidad de la señal se hallaba reducida (Figura 8B), sugiriéndonos que los niveles de quitina de esta cepa deberían encontrarse disminuidos en estas condiciones. Por ello cuantificamos la cantidad de este polímero en los cultivos del mutante yn/294A al crecer en medio rico YEPD suplementado con calcoflúor durante 3 horas. Este mutante contenía tan sólo el $44 \%$ de la quitina respecto a la estirpe silvestre en estas mismas condiciones (Tabla 5). Esta disminución era por tanto debida a un menor incremento de la síntesis de quitina durante el tratamiento con calcoflúor. De manera similar, los mutantes $s / t 2 \Delta$ y $r / m 1 \Delta$ presentaban también una disminución de la fluorescencia al realizar una tinción de quitina con calcoflúor (Datos no mostrados) y un descenso en el porcentaje de quitina en cultivos que habían crecido en presencia de este fluorocromo (Tabla 5). Puesto que $s / t 2 \Delta$ y $r / m 1 \Delta$ carecen de la respuesta transcripcional llevada a cabo por la ruta de integridad celular (Levin, 2005), y el

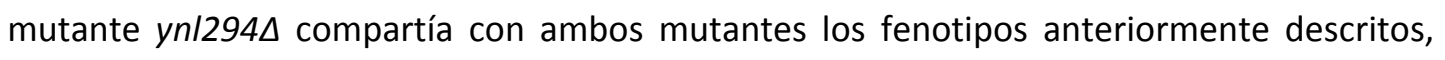
era necesario analizar los fenotipos del mutante yn/294 $\Delta$ asociados a la ausencia de esta ruta de señalización.

Para ello determinamos si la cepa yn/2944 presentaba defectos adicionales en el ensamblaje de la pared celular analizando la sensibilidad/resistencia frente a varios 

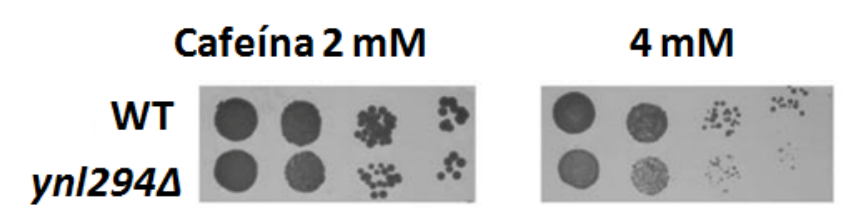

SDS $\quad 0.01 \%$
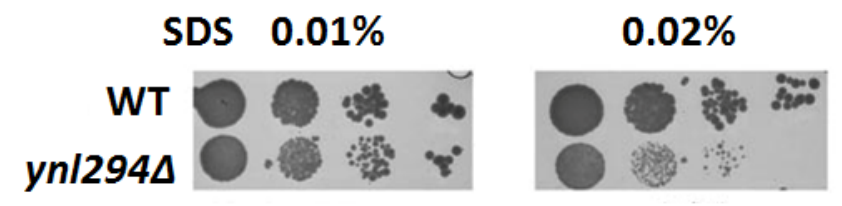

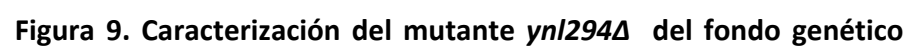
BY4741. Ensayo de sensibilidad frente a cafeína y SDS a las concentraciones indicadas en medio YEPD. compuestos que afectan a esta estructura, como son el SDS y la cafeína. Tal y como se muestra, el crecimiento del mutante yn/294A en medio sólido se encontraba reducido tanto en presencia de SDS al $0.002 \%$ como de cafeína 4mM (Figura 9).

Durante el desarrollo de este trabajo se propuso que Ynl294p podría ser homóloga, junto con Dfg16p, de la proteína PalH de Aspergillus nidulans (Barwell et al., 2005) que posee siete dominios transmembrana (Penalva et al., 2008). Ambas proteínas de S. cerevisiae también contienen múltiples dominios transmembrana que son requeridos para la transducción de la señal frente a pH alcalino (Barwell et al., 2005). La implicación de Ynl294p en la ruta de crecimiento a pH alcalino, conocida también como ruta RIM101 en esta levadura, se verificó directamente al demostrar que el mutante yn/2944 presentaba crecimiento reducido a pH 7.6 y mostraba sensibilidad a altas concentraciones catiónicas, pero no a alta osmolaridad (Figura 10). El gen YNL294 era ya nombrado en la mayoría de las bases de

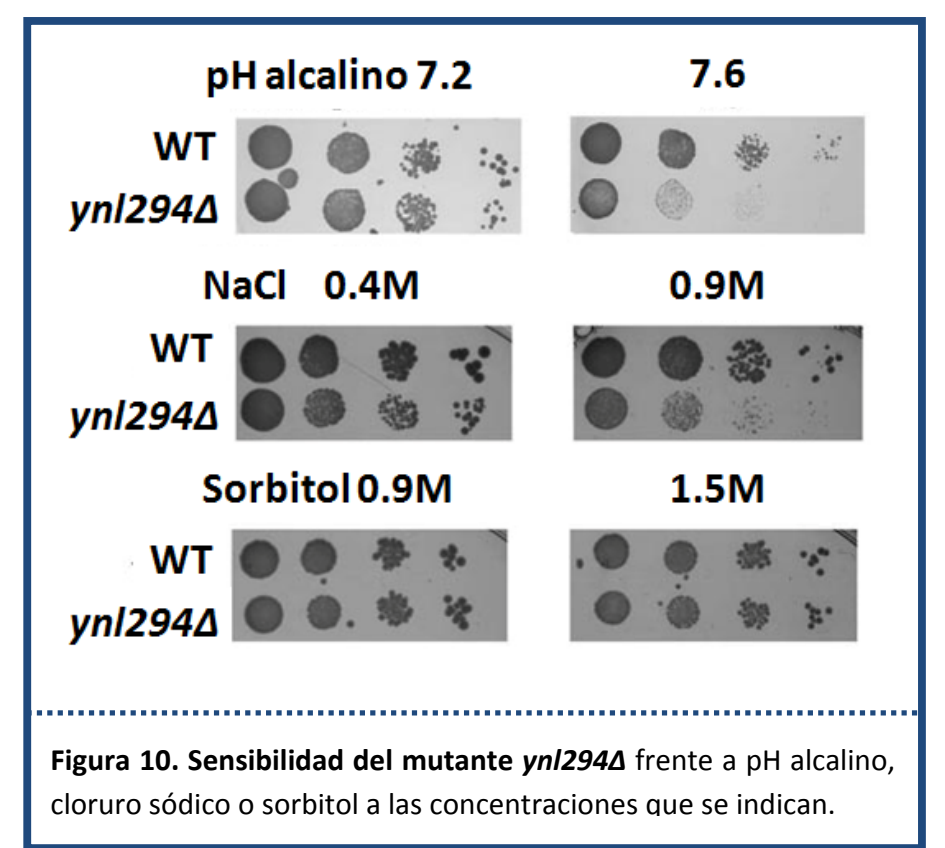

datos como RIM21, por lo que a partir de este momento será mencionado en esta memoria como RIM21/Rim21p.

Los resultados obtenidos hasta el momento indicaban que además de los defectos en el crecimiento a $\mathrm{pH}$ alcalino, el mutante rim21ム compartía con el mutante slt2 $\Delta$ varios fenotipos relacionados con defectos en la pared 


\section{Resultados}

celular. Puesto que la proteína Rim21p se describió como sensor putativo de la ruta RIM101, propusimos como hipótesis inicial la posible implicación de esta proteína como un sensor adicional de la ruta de integridad celular. Para confirmar esta idea, determinamos el grado de activación de la ruta PKC en el mutante rim21 2 tras un tratamiento con calcoflúor. Tal y como se muestra en la figura 11, el calcoflúor provoca en la cepa silvestre una activación de la ruta de integridad celular que se puede observar en forma de una fosforilación de SIt $2 p$ rápida y prolongada en el tiempo. En contraposición, la respuesta en el mutante rim21 21 en estas mismas condiciones se encontraba prácticamente ausente, lo que nos estaba sugiriendo la participación específica de la proteína Rim21p en la activación de la ruta PKC tras un daño sobre la pared celular provocado por calcoflúor.

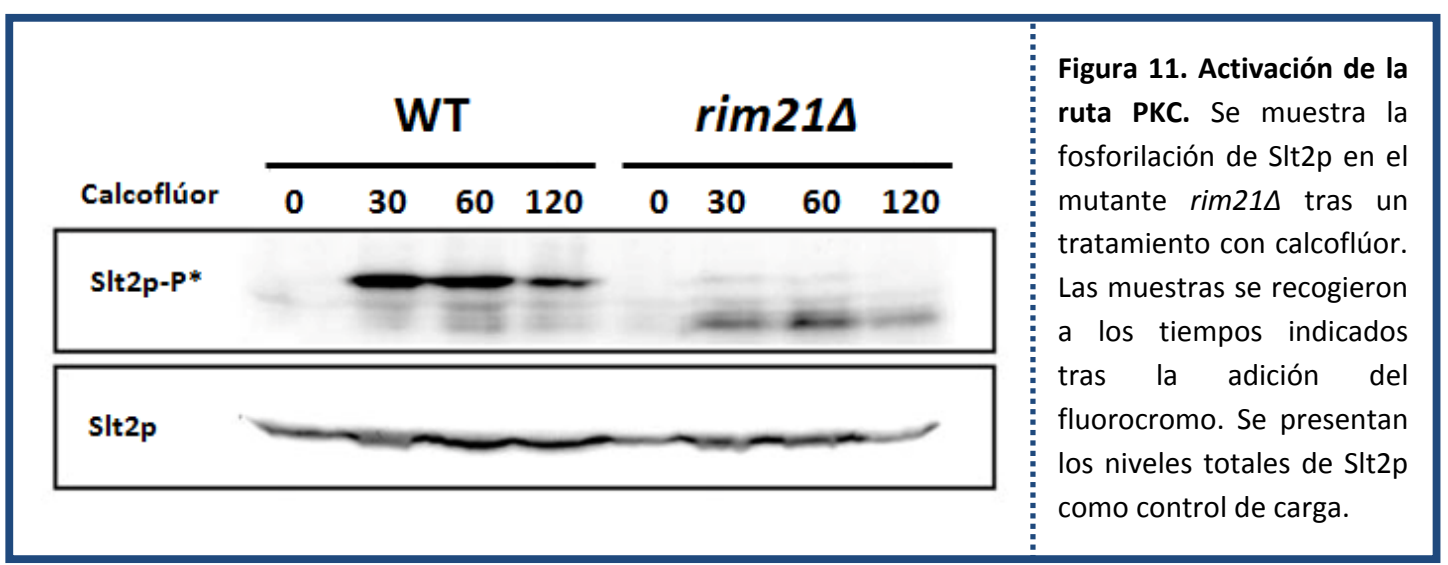

\subsection{Letalidad sintética entre s/t2 $\Delta$ y mutantes rim $\Delta$}

Para verificar la posible relación entre Rim21p y la construcción de la pared celular, decidimos efectuar cruces entre rim $21 \Delta$ y mutantes nulos con defectos en la pared celular para determinar si entre estos genes existía una relación sintética letal. Se dice que dos genes muestran una interacción genética que causa letalidad sintética cuando la combinación de mutaciones en ambos genes, que de forma independiente son viables, origina la muerte celular. Estas interacciones pueden darse en genes de dos rutas distintas si un proceso funcional compensa los defectos del otro (Boone et al., 2007). En contra de lo

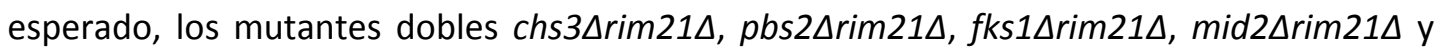

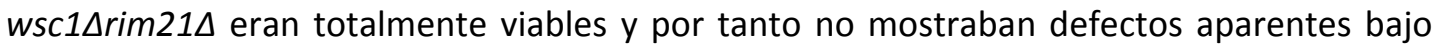
condiciones normales de crecimiento (Datos no mostrados). La caracterización fenotípica 


\begin{tabular}{|c|c|c|c|c|c|}
\hline \multirow[b]{2}{*}{ Cruce } & \multirow[b]{2}{*}{ Medio } & \multicolumn{4}{|c|}{ Viabilidad de las esporas y genotipo } \\
\hline & & $\begin{array}{c}\text { SLT2 RIM21 } \\
\text { (101) }\end{array}$ & $\begin{array}{c}\text { slt2 } 2 \text { RIM21 } \\
\text { (101) }\end{array}$ & $\begin{array}{c}\text { SLT2 rim214 } \\
\text { (1014) }\end{array}$ & $\begin{array}{c}\text { slt2 } 2 \Delta \operatorname{rim} 21 \Delta \\
(101 \Delta)\end{array}$ \\
\hline \multirow{2}{*}{ slt2 $2 \Delta \mathrm{x}$ rim $21 \Delta$} & YEPD & 27 & 30 & 28 & 0 \\
\hline & YEPD +S & 28 & 29 & 30 & 17 \\
\hline \multirow{2}{*}{ s/t2 $2 \Delta \times \operatorname{rim} 101 \Delta$} & YEPD & 29 & 49 & 44 & 0 \\
\hline & YEPD +S & 28 & 47 & 46 & 15 \\
\hline $\begin{array}{c}r \operatorname{lm} 1 \Delta \times \operatorname{rim} 21 \Delta \\
(101 \Delta)\end{array}$ & YEPD & $4(6)$ & $4(10)$ & $6(8)$ & $8(7)$ \\
\hline
\end{tabular}

Tabla 6. Viabilidad de las esporas de diferentes cruces. La viabilidad de las esporas indica el número de esporas de cada genotipo capaces de germinar en el medio descrito tras la disección de tétradas. También se muestra el genotipo del diploide de origen. Entre paréntesis se presentan los datos del genotipo alternativo RIM101/rim101D.

de estos mutantes dobles indicó que los defectos presentados eran sumatorios, excepto en

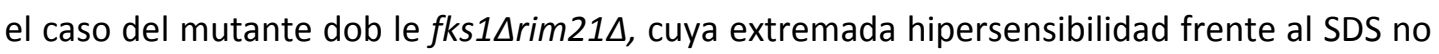
se podía explicar simplemente por el efecto aditivo de la deleción de cada gen por separado (Datos no mostrados).

Sin embargo cuando micromanipulamos sobre placas de medio rico YEPD 34 tétradas procedentes del cruce de los mutantes rim $21 \Delta$ y slt2 $2 \Delta$, no fuimos capaces de

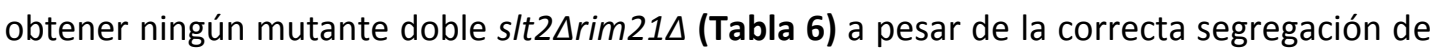
los dos caracteres, resultado que sugería la existencia de una letalidad sintética entre slt2 $\Delta$ y rim21 2 . Al suplementar las placas con sorbitol $1 \mathrm{M}$, se comprobó que se obtenían

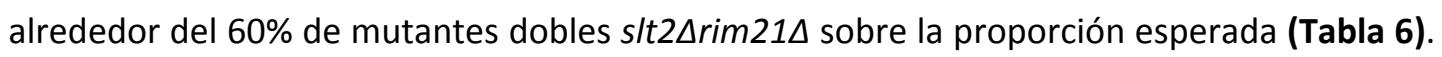
La supresión de la muerte celular llevada a cabo por el sorbitol es indicativa de que la letalidad sintética podría estar directamente relacionada con un defecto en la pared celular, ya que el sorbitol aliviaría este problema mediante la estabilización osmótica del medio de crecimiento.

Nuestra hipótesis inicial postulaba un posible papel de Rim21p como sensor de la ruta PKC, y en este caso no debería existir un nexo entre la ruta RIM101 y la ruta de integridad celular más allá de la implicación de Rim21p en ambas cascadas de señalización, hipótesis que parecía contradecir los resultados obtenidos. Para analizar esta posibilidad con más detalle, procedimos a la caracterización fenotípica del mutante rim1014, que 


\section{Resultados}

carece del factor de transcripción de la ruta RIM101. Este mutante era sensible frente al SDS y la cafeína (Datos no mostrados) y contenía cantidades de quitina comparables a las presentadas por la estirpe silvestre (Tabla 5), pero cuando los cultivos de este mutante eran tratados con calcoflúor, la síntesis de este polímero se incrementaba tan sólo dos veces respecto a la cepa silvestre (Tabla 5), de forma similar a lo observado en el mutante rim21 $\Delta$. De igual manera cabe destacar que fuimos incapaces de obtener el mutante doble

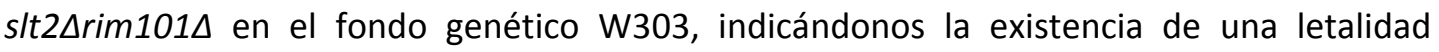
sintética entre ambos mutantes simples, que también era suprimida en presencia de

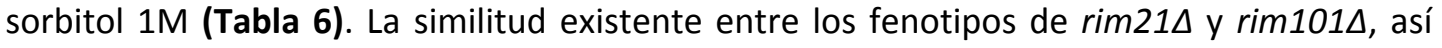
como la letalidad sintética que presentan con slt2 $\Delta$, sugerían una acción paralela de las dos rutas en el ensamblaje de la pared celular, descartando en principio un papel directo de Rim21p en la ruta PKC, y por lo tanto nuestra hipótesis inicial.

Además, posteriormente se comprobó que el resto de mutantes que carecen de las

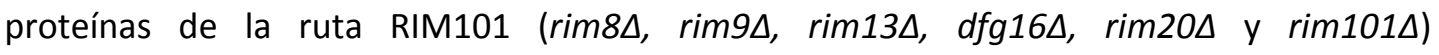
presentaban los mismos defectos observados en rim21 sensibilidad frente a pH alcalino y a altas concentraciones salinas (Figura 12), pero además todos estos mutantes también presentaban la misma resistencia parcial frente a calcoflúor (Figura 12). Estos resultados indicaban un papel global de la ruta RIM101 en el ensamblaje de la pared celular, algo totalmente desconocido hasta el momento.

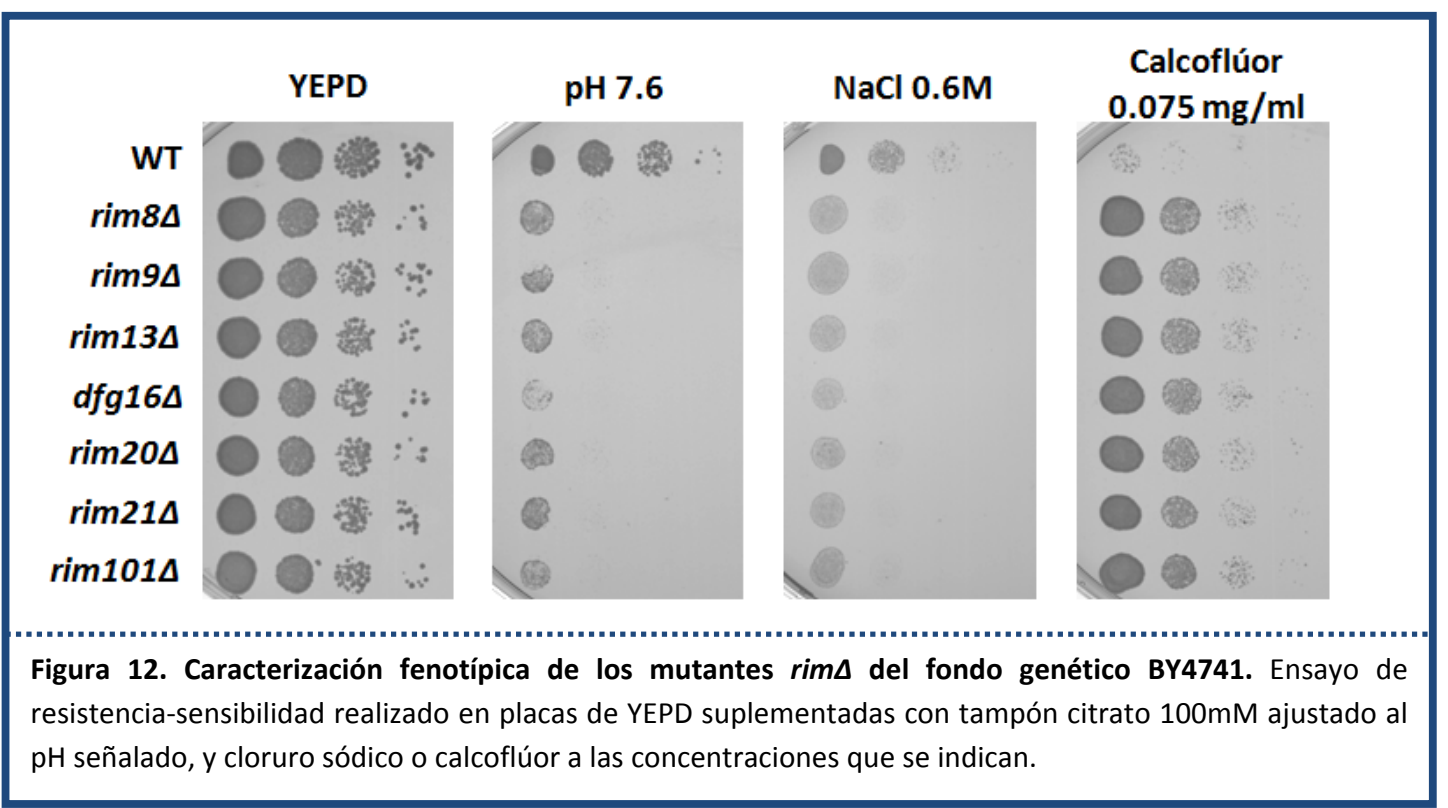


Hasta la fecha sólo se había observado una interacción de letalidad sintética entre

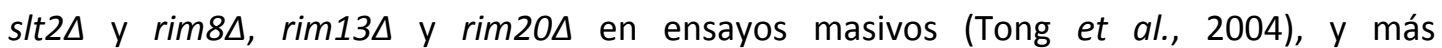
recientemente, entre slt2 $\Delta$ y $d f g 16 \Delta$ (http://drygin.ccbr.utoronto.ca/). Sin embargo, en ningún caso se había observado una interacción genética negativa de slt2 $\Delta$ con rim21 0 rim101ム, lo que podría deberse a los problemas metodológicos que están asociados a este

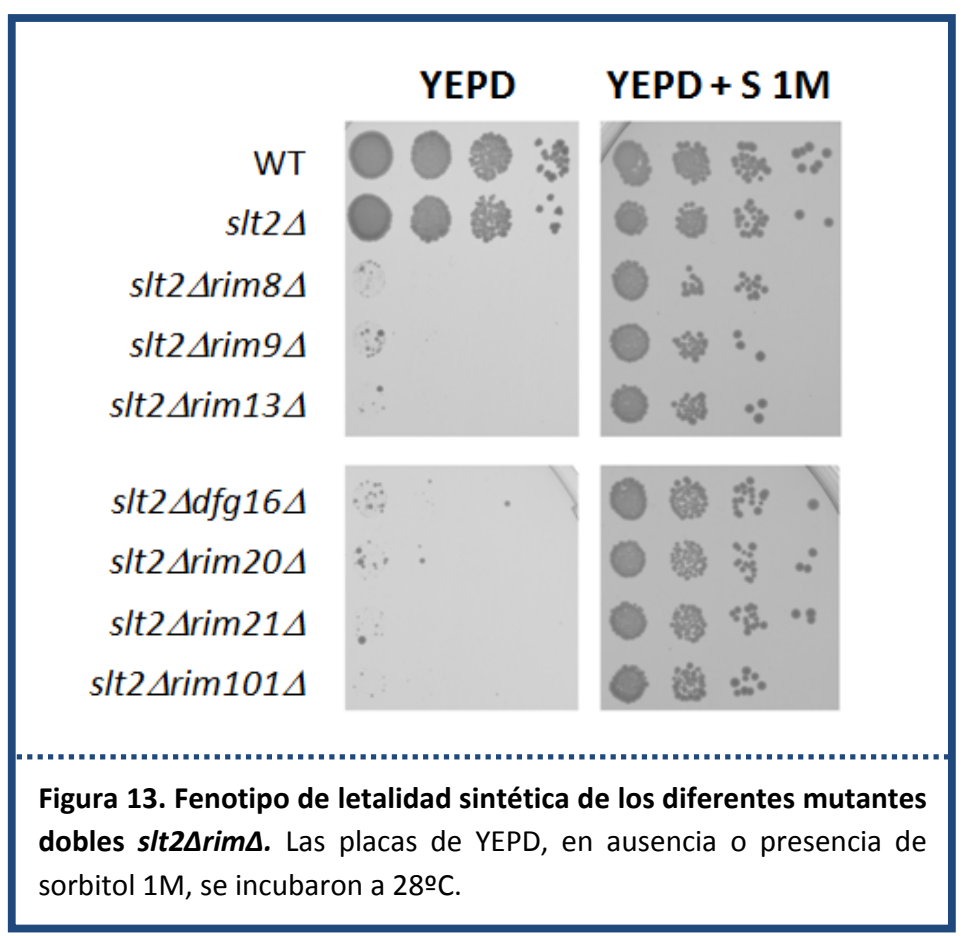
tipo de ensayos masivos y al empleo de diferentes fondos genéticos. Para confirmar esto, construimos todos los mutantes dobles carentes de SLT2 y de cada uno de los componentes de la ruta RIM101, transformando el mutante slt2 $\Delta$ con el casete de deleción de cada uno de los mutantes rims que poseían el marcador de selección de resistencia a la nourseotricina. Una vez seleccionados los mutantes dobles en sorbitol $1 \mathrm{M}$, se hizo un ensayo de gota en placas de YEPD en presencia y ausencia de sorbitol. Observamos que en el fondo genético W303 ninguno de los mutantes dobles era capaz de crecer en ausencia de sorbitol (Figura 13), revertiéndose este fenotipo cuando suplementábamos el medio con este estabilizador osmótico, lo cual confirmaba que todos los mutantes de la ruta RIM101 presentaban una interacción de letalidad sintética con slt2 $\Delta$. Este fenotipo afianzaba la idea de que la ruta RIM101 como entidad única se encontraba implicada en el ensamblaje de la pared celular, actuando en paralelo a la ruta PKC.

RIm1p es un factor de transcripción activado directamente por Slt2p, es responsable de la mayoría de la respuesta transcripcional de la ruta de integridad celular (Levin, 2005), y está encargado de llevar a cabo la conocida como respuesta compensatoria. Esta respuesta controla la expresión de al menos 25 genes implicados en la biogénesis de la pared celular. Aunque la inactivación de la ruta RIM101 en el mutante slt2 $\Delta$ daba lugar a 


\section{Resultados}

células no viables, no sucedía lo mismo en el mutante $r / m 1 \Delta$, ya que los mutantes dobles

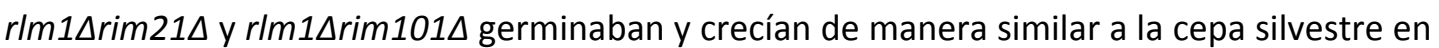
ausencia de un estabilizador osmótico (Tabla 6). Estos resultados sugieren que deben existir niveles de control del ensamblaje de la pared celular a través de la ruta PKC desconocidos hasta la fecha y que serían adicionales a la respuesta compensatoria descrita.

\subsection{Análisis de la deleción de SMP1 sobre rim21ム}

Trabajos previos describen la existencia de dos represores transcripcionales, NRG1 y SMP1, que se encuentran bajo el control del factor de transcripción Rim101p (Lamb \& Mitchell, 2003). Smp1p es un factor de transcripción de la familia de las MADS-box al igual que RIm1p, con el que posee una alta similitud (Dodou \& Treisman, 1997). Este hecho nos

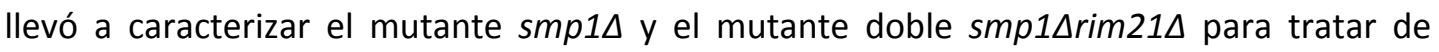
estudiar si la desregulación de Smp1p tenía una implicación directa en el ensamblaje de la pared celular. El mutante simple smp1s no mostraba ningún fenotipo relacionado con defectos en la pared celular, ya que ni presentaba sensibilidad frente al SDS ni resistencia al calcoflúor. Asimismo crecía perfectamente en presencia de $\mathrm{NaCl}$ al realizar ensayos de sensibilidad/resistencia en medio sólido (Figura 14A).

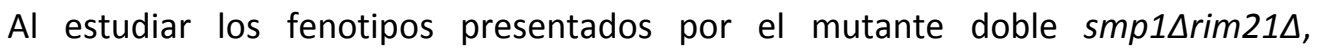
observamos que la deleción de SMP1 no suprimía la sensibilidad de rim21 frente al SDS o al cloruro sódico (Figura 14A). Sin embargo este mutante doble mostraba una resistencia reducida frente al calcoflúor, sensiblemente menor que la del mutante simple rim21ડ

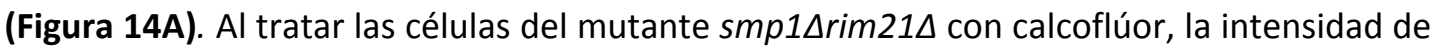
la señal era intermedia entre la que mostraban el mutante rim210 y la estirpe silvestre (Figura 14B), sugiriendo que la deleción de SMP1 recuperaba parcialmente los niveles de quitina mostrados por el mutante rim21د. Este hecho se confirmó posteriormente al realizar una valoración cuantitativa de este polímero (Figura 14C). Todos estos resultados descartan por tanto que la desrepresión de SMP1 sea el único vínculo que relaciona a la ruta RIM101 con el ensamblaje de la pared celular, sugiriendo mecanismos más complejos en los cuales la desrepresión de SMP1 podría estar parcialmente implicada. 


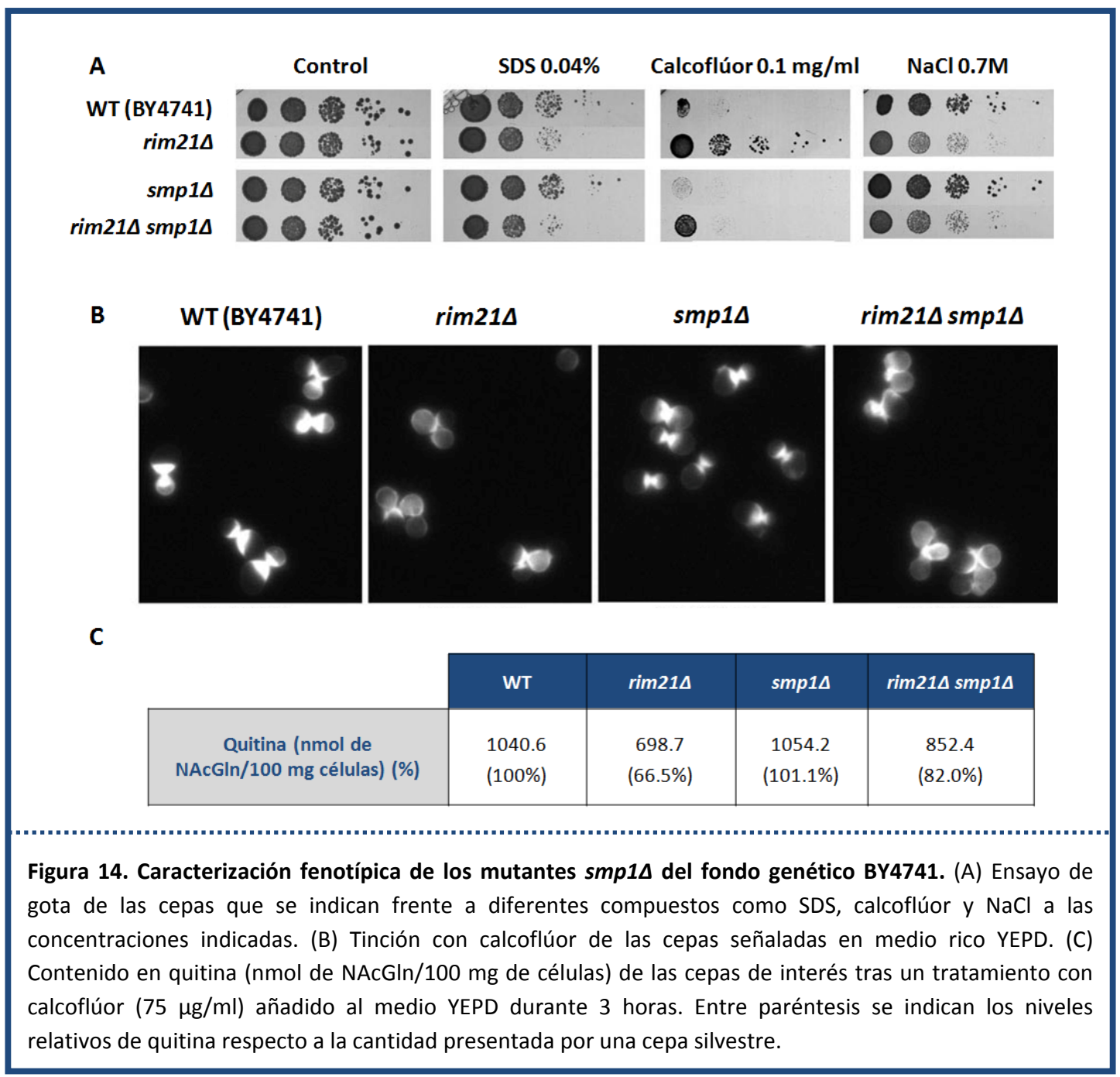

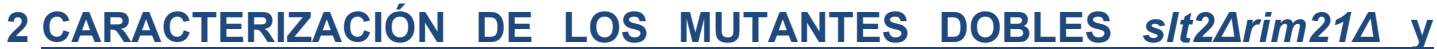

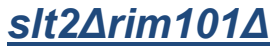

\subsection{Caracterización fenotípica de los mutantes dobles}

Para intentar entender con mayor detalle el papel que desempeña la ruta RIM101 en la construcción de la pared celular, analizamos en detalle los fenotipos que mostraba el

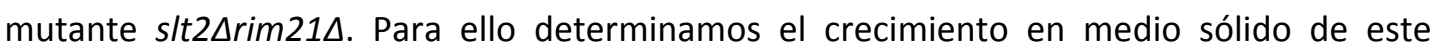
mutante doble, observándose que tan sólo la presencia del sorbitol posibilitaba su crecimiento, mientras que en ausencia de dicho estabilizador osmótico, apenas existía crecimiento de dicha cepa (Figura 15A); resultados similares se observaron para el mutante 


\section{Resultados}

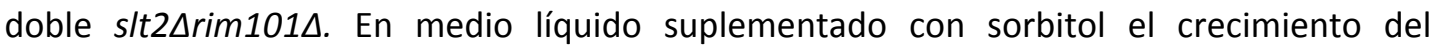

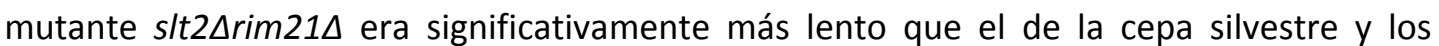

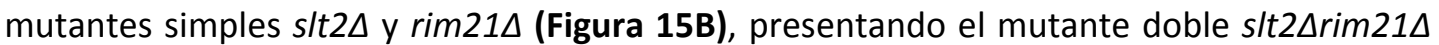
un tiempo de generación de 222 minutos, que es aproximadamente el doble del que mostraban los mutantes sencillos s/t2 $2 \Delta$ y rim $21 \Delta$ (110 y 112 minutos respectivamente) en el mismo medio. Podemos concluir por tanto que aunque el sorbitol permite el crecimiento del mutante doble, no corrige los defectos intrínsecos del mismo.
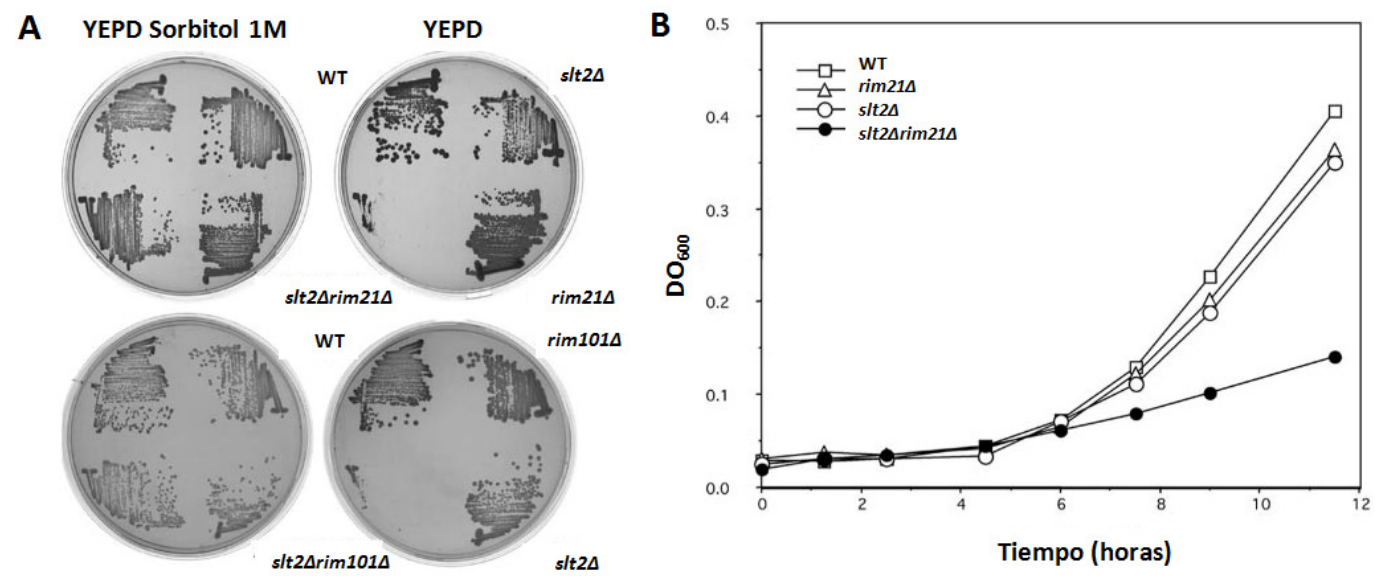

Figura 15. Crecimiento de las cepas indicadas en diferentes medios. (A) Las cuatro esporas de diferente genotipo procedentes de una tétrada fueron reestriadas en placas de medio YEPD en ausencia y presencia de sorbitol $1 \mathrm{M}$, y se incubaron durante 3 días a $28^{\circ} \mathrm{C}$. (B) Curva de crecimiento llevada a cabo en medio líquido YEPD suplementado con sorbitol $1 \mathrm{M}$.

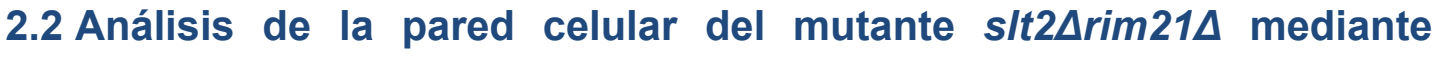 microscopía electrónica de transmisión}

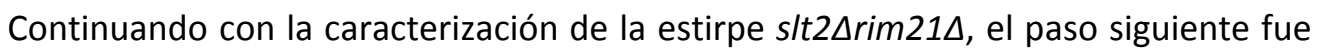
determinar la ultraestructura de la pared celular mediante microscopía electrónica de transmisión. Para ello se utilizó como medio de cultivo el medio rico YEPD suplementado con sorbitol 1M. De forma general, las células del mutante doble parecían bastante similares a las de los mutantes simples $\operatorname{sit} 2 \Delta$ y $\operatorname{rim} 21 \Delta$, y a las de la cepa silvestre (Figura 16A), pero cuando se observaron con más detalle (Figura 16B), se percibieron algunas diferencias. El grosor de la pared celular de las células de $\operatorname{sit} 2 \Delta \operatorname{rim} 21 \Delta(0.217 \pm 0.006 \mu \mathrm{m})$ era aproximadamente el doble del de las cepas wt $(0.149 \pm 0.01 \mu \mathrm{m})$, s/t2 $\Delta(0.136 \pm 0.008 \mu \mathrm{m})$ y $\operatorname{rim} 21 \Delta(0.143 \pm 0.009 \mu \mathrm{m})$. Además, la capa más externa y densa a los electrones, que se 
encuentra formada por manoproteínas, parecía menos definida en el caso del mutante doble, indicando que la pared celular en esta cepa posee defectos estructurales que sugieren una alteración en el ensamblaje de la misma.

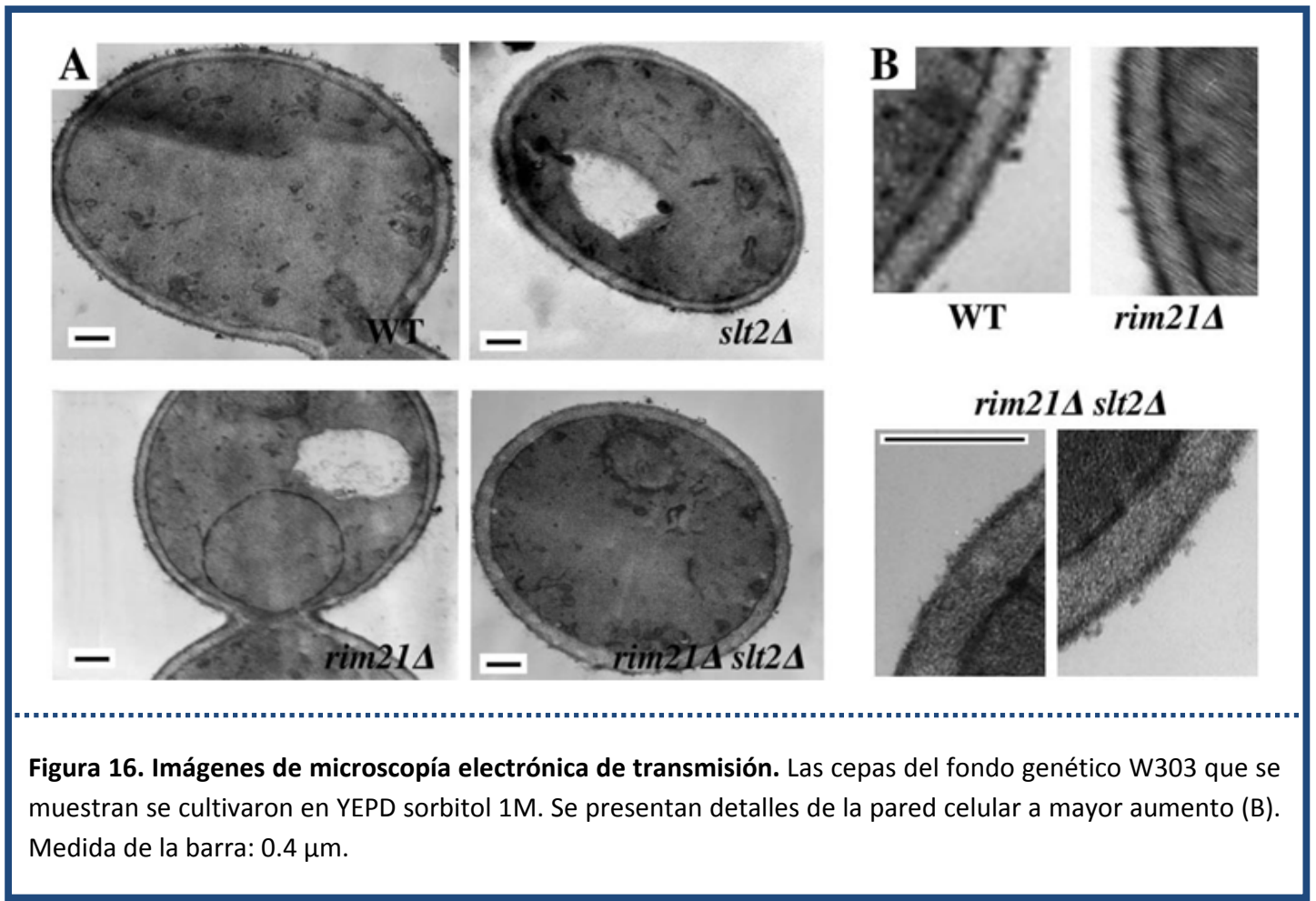

\subsection{Sensibilidad del mutante slt2 $\Delta$ rim21 $\Delta$ frente a zimoliasa}

Al observar que la pared celular del mutante doble mostraba defectos en su estructura, quisimos realizar un ensayo de sensibilidad frente a zimoliasa en medio líquido. Ésta es una mezcla de enzimas hidrolíticas, principalmente $\beta$-(1,3)-glucanasas y proteasas, que digiere la pared y puede producir la lisis celular en última instancia. Pudimos apreciar que el mutante simple rim21 $1 \Delta$ mostraba una sensibilidad parcial frente a la zimoliasa 100T al realizar el ensayo en medio rico YEPD, observándose un resultado similar para el mutante rim101ऽ (Figura 17A). Sin embargo, ambos mutantes eran capaces de crecer incluso a las concentraciones más altas que se han ensayado. Por otra parte, el mutante slt2 $\Delta$ en estas mismas condiciones era incapaz de activar la respuesta compensatoria en presencia de zimoliasa, siendo extremadamente hipersensible incluso a concentraciones tan bajas como $250 \mathrm{mU}$, donde el crecimiento de dicho mutante era nulo. 


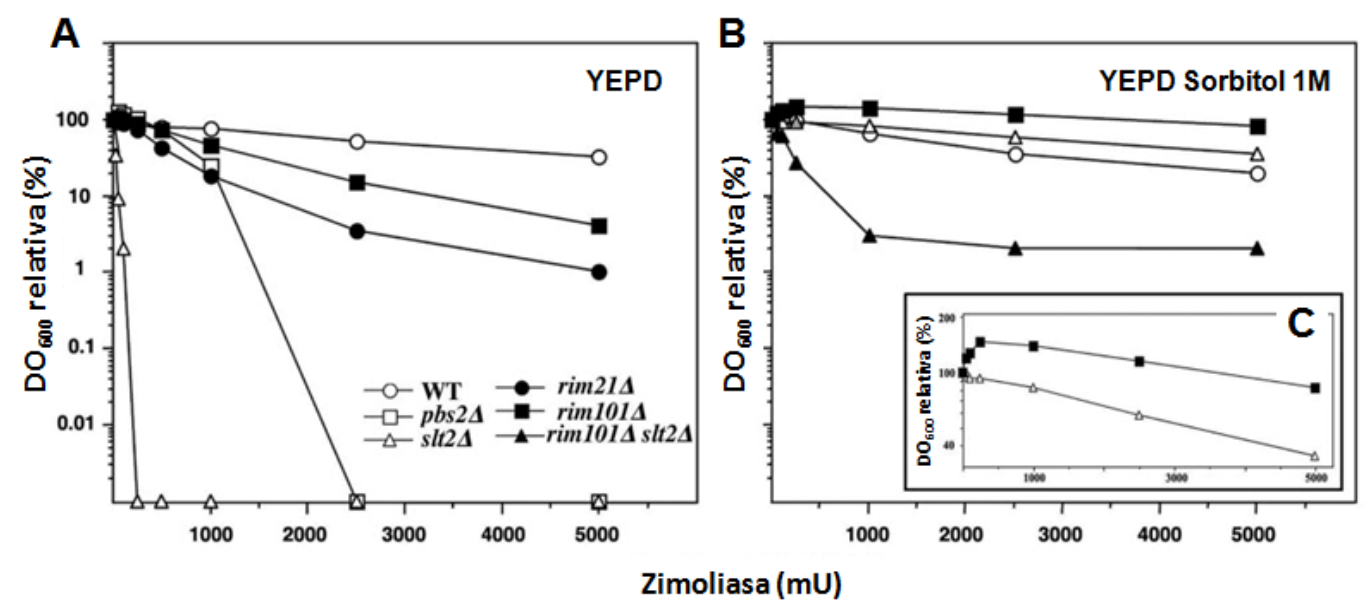

Figura 17. Ensayo de sensibilidad frente a zimoliasa. (A) Crecimiento de las cepas indicadas en medio líquido YEPD con concentraciones crecientes de zimoliasa 100T. Los datos se muestran como porcentajes en escala logarítmica, mostrándose el crecimiento relativo de los cultivos en presencia de zimoliasa respecto a un cultivo idéntico en ausencia de tratamiento. El mutante pbs $2 \Delta$ se usó como control, ya que muestra una sensibilidad moderada frente a zimoliasa. (B) Mismo experimento que en la gráfica A, pero empleando YEPD sorbitol $1 \mathrm{M}$ como medio de cultivo. (C) Se puede observar la comparación del crecimiento del mutante rim101ム y la cepa silvestre de la gráfica B a mayor escala.

Sin embargo, al realizar el experimento en medio suplementado con sorbitol, la hipersensibilidad del mutante $s / t 2 \Delta$ disminuía significativamente hasta alcanzar los niveles de crecimiento de la estirpe silvestre (Figura 17B). En estas condiciones, el mutante rim101ム presentaba un crecimiento incluso mejor que el de la cepa wt (Figura 17C). No obstante, el mutante doble slt2 $\operatorname{rim} 101 \Delta$ mostraba una sensibilidad frente a la zimoliasa bastante mayor al ser comparada con el resto de las cepas (Figura 17B). Resultados muy similares se observaron para el mutante s/t2 $\Delta$ rim21 $\Delta$ (Datos no mostrados).

De todos los datos recogidos en los apartados 1 y 2 se puede concluir un papel claro de la ruta RIM101 en el ensamblaje de la pared celular, sin permitirnos deducir cuál es exactamente la función que desempeña. Los datos genómicos sobre la ruta RIM101 indican un posible papel de esta ruta a través de la desregulación de varios genes como YJRO61W, KTR5, CTS1, UTR2, WSC4, SHC1, CWP1, FLO10, etc (Lamb \& Mitchell, 2003). Teniendo en cuenta que estos genes no tienen un papel estructural significativo en la pared, es de esperar que su desregulación produzca sólo cambios menores en su estructura. Desafortunadamente, el estudio de esas alteraciones menores implica el uso de metodologías que no resultan fácilmente asequibles. Por ello nos planteamos como 
alternativa la caracterización de estos defectos mediante el aislamiento de supresores de la letalidad sintética (Apartado 3).

\section{SUPRESORES DE LA LETALIDAD SINTÉTICA DE slt2Arim101ム}

\subsection{Búsqueda de supresores}

Para profundizar en las causas moleculares de la letalidad sintética existente entre slt2 2 y rim1014, nos propusimos realizar una búsqueda de supresores extragénicos. Para ello empleamos una genoteca de ADN genómico de $S$. cerevisiae construida en el plásmido multicopia YEp13 (American Type Culture Collection, ATCC 37323) que contiene el marcador LEU2. El primer paso fue amplificar dicha genoteca en la cepa $\mathrm{DH} 5 \alpha$ de Escherichia coli.

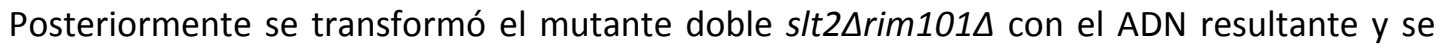
plaqueó en medio SC selectivo suplementado con sorbitol a $28^{\circ} \mathrm{C}$, obteniendo alrededor de 10000 clones. Para alcanzar este número se tuvieron que realizar varias transformaciones, debido a que la eficiencia de transformación de la cepa slt2 2 rim $101 \Delta$ es muy reducida. La eficiencia también resultaba bastante baja por el elevado tamaño del plásmido YEp13, 11 $\mathrm{Kb}$ sin contar con el inserto que contuviera cada uno de los clones. La selección de los transformantes supresores no se pudo realizar directamente en medio SC en ausencia de sorbitol, puesto que en estas condiciones se producía un crecimiento parcial del mutante doble (Resultados no mostrados). Los primeros supresores se aislaron y caracterizaron a partir del crecimiento en medio YEPD incubado a 37ํㅡ. En estas condiciones sólo crecieron clones que incluían el gen $S L T 2$, por lo que se modificó la estrategia de selección. Para ello, todos los transformantes se reestriaron en placas de YEPD que se incubaron a 28,35 y $37^{\circ} \mathrm{C}$. Los clones que eran capaces de crecer al menos a 28 y $35^{\circ} \mathrm{C}$ en este medio se seleccionaron para su confirmación definitiva. De todos aquellos transformantes capaces de crecer en estas condiciones se aisló el plásmido en E. coli y con los plásmidos obtenidos

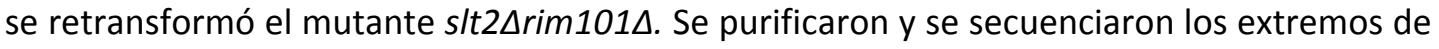
aquéllos en los que se confirmó una capacidad para suprimir la letalidad sintética,. Las secuencias nos permitieron identificar 13 insertos diferentes que incluían los genes descritos en la tabla 7. Se puede observar que el gen SLT2 se encontraba presente en 


\begin{tabular}{|c|c|}
\hline $\begin{array}{l}\text { INSERTO Y } \\
\text { TAMANOO }\end{array}$ & GENES CONTENIDOS \\
\hline $\begin{array}{l}\text { Inserto \#1 } \\
\text { (6046 pb) }\end{array}$ & $\begin{array}{l}\text { - Fragmento de DAP2: dipeptidil aminotransferasa. } \\
\text { - YHRO28W-A: fase de lectura abierta dudosa. } \\
\text { - YHI9: proteína de función desconocida. } \\
\text { - SLT2: serina/treonina MAP quinasa implicada en el mantenimiento de la } \\
\text { integridad de la pared celular y la progresión del ciclo celular. } \\
\text { - Fragmento de RRM3: ADN helicasa. }\end{array}$ \\
\hline $\begin{array}{l}\text { Inserto \#2 } \\
\text { (8425 pb) }\end{array}$ & $\begin{array}{l}\text { - Fragmento de } Y K L 105 C \text { : proteína de función desconocida. } \\
\text { - GFA1: glutamina-fructosa-6-fosfato amidotransferasa, que participa en el primer } \\
\text { paso de la biosíntesis de quitina. } \\
\text { - LAP4: aminopeptidasa vacuolar. } \\
\text { - YKL102C: fase de lectura abierta dudosa. } \\
\text { - Fragmento de } H S L 1 \text { : proteína quinasa relacionada con Nim1p que regula el } \\
\text { checkpoint de morfogénesis y septinas. }\end{array}$ \\
\hline $\begin{array}{l}\text { Inserto \#3 } \\
\text { (5722 pb) }\end{array}$ & $\begin{array}{l}\text { - PCL1: ciclina que interacciona con la CDK Pho85p, involucrada en la regulación } \\
\text { de crecimiento polarizado, morfogénesis y progresión del ciclo celular. } \\
\text { - SNR40: ARN nucleolar pequeño. } \\
\text { - CAF40: subunidad del complejo CCR4-NOT. } \\
\text { - Fragmento de SEC21: subunidad gamma del coatómero }\end{array}$ \\
\hline $\begin{array}{l}\text { Inserto \#4 } \\
\text { (5375 pb) }\end{array}$ & $\begin{array}{l}\text { - RNH1: ribonucleasa } \mathrm{H} 1 \text {. } \\
\text { - RNA1: GAP de Gsp1p, involucrada en transporte nuclear } \\
\text { - TAF9: subunidad de los complejos TFIID y SAGA. } \\
\text { - Fragmento de } B C H 1 \text { : miembro de la familia ChAPs }\end{array}$ \\
\hline $\begin{array}{l}\text { Inserto \#5 } \\
\text { (2947 pb) }\end{array}$ & $\begin{array}{l}\text { - MSC3: proteína de función desconocida. } \\
\text { - Fragmento de CCC1: transportador vacuolar } \mathrm{Fe}^{2+} / \mathrm{Mn}^{2+}\end{array}$ \\
\hline Inserto \#6 & - Retrotransposón \\
\hline $\begin{array}{l}\text { Inserto \#7 } \\
\text { (5717 pb) }\end{array}$ & $\begin{array}{l}\text { - Fragmento de NAB3: proteína de unión a ARN de cadena sencilla. } \\
\text { - COA2: factor de ensamblaje de la citocromo oxidasa } \\
\text { - GUP2: proteína con posible papel en el simporte H+/glicerol } \\
\text { - Fragmento de POS5: quinasa mitocondrial de NADH }\end{array}$ \\
\hline $\begin{array}{l}\text { Inserto \#8 } \\
\text { (7861 pb) }\end{array}$ & $\begin{array}{l}\text { - SPH1: proteína homóloga a Spa2p, involucrada en la formación del shmoo y la } \\
\text { selección del sitio de gemación bipolar } \\
\text { - CDC3: componente esencial del anillo de septinas } \\
\text { - NKP2: proteína no esencial del cinetocoro } \\
\text { - TAD3: subunidad de la adenosina-34 deaminasa específica de ARN transferente } \\
\text { - YNR317W: fase de lectura abierta dudosa. } \\
\text { - Fragmento de EST2: subunidad de la transcriptasa reversa de la holoenzima } \\
\text { telomerasa. }\end{array}$ \\
\hline
\end{tabular}




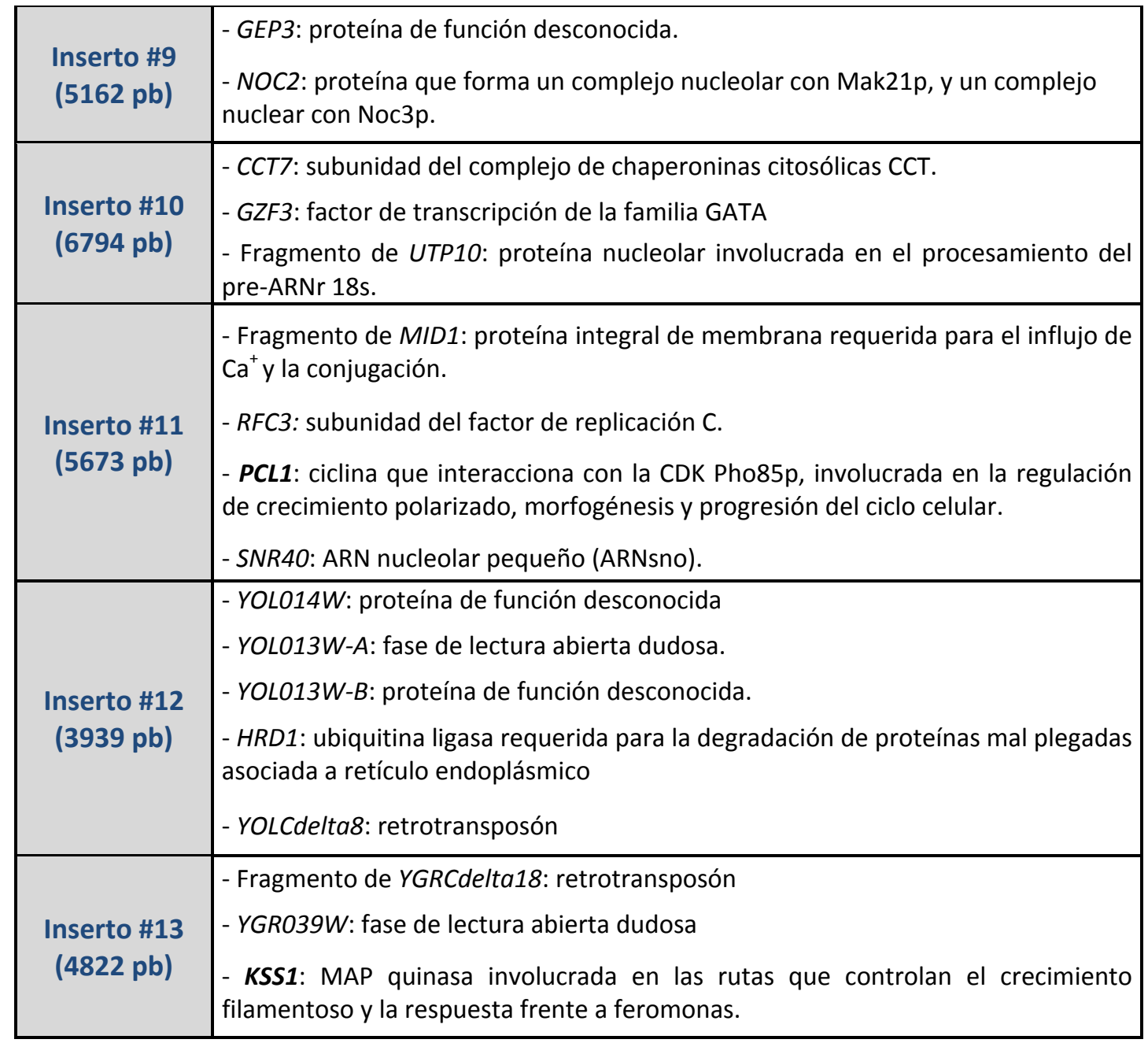

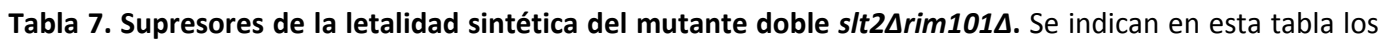
genes contenidos en cada uno de los insertos de los supresores aislados, así como la función que está descrita para ellos. Entre paréntesis se muestra el tamaño de cada inserto. En negrita se indican aquellos genes cuyo papel podría estar a priori relacionado con la supresión.

el plásmido \#1, lo cual explicaba que este transformante fuera capaz de crecer normalmente a todas las temperaturas (incluso a $37^{\circ} \mathrm{C}$ ). Mediante enzimas de restricción se comprobó que el gen SLT2 estaba también presente en otro inserto (Datos no mostrados).

Algo sorprendente fue el hecho de no encontrar el gen RIM101 entre los supresores aislados. Sin embargo, el gen RIM101 en plásmido centromérico o multicopia era capaz de

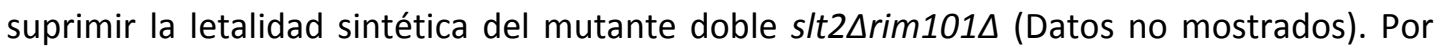
tanto podríamos asumir que nuestro escrutinio no estuviera aún saturado, o bien que el gen RIM101 pudiera estar poco representado en nuestra genoteca. Tanto el gen SLT2 como 


\section{Resultados}

PCL1 aparecieron dos veces en diferentes insertos, lo cual sugería que lo más probable era que la genoteca de $S$. cerevisiae con la que se realizó el ensayo tuviera una menor proporción de RIM101 y que por ello no fuéramos capaces de aislarlo.

Una vez identificadas las fases de lectura abierta de cada inserto, procedimos subclonar las mismas para identificar el gen responsable de la supresión. En la figura $\mathbf{1 8}$ se resumen los resultados concluyentes que permiten asignar la capacidad supresora bona fide a los genes SLT2, CCT7, GFA1, PCL1 y KSS1. La caracterización del resto de los insertos no proporcionó información concluyente y su estudio no se ha continuado.

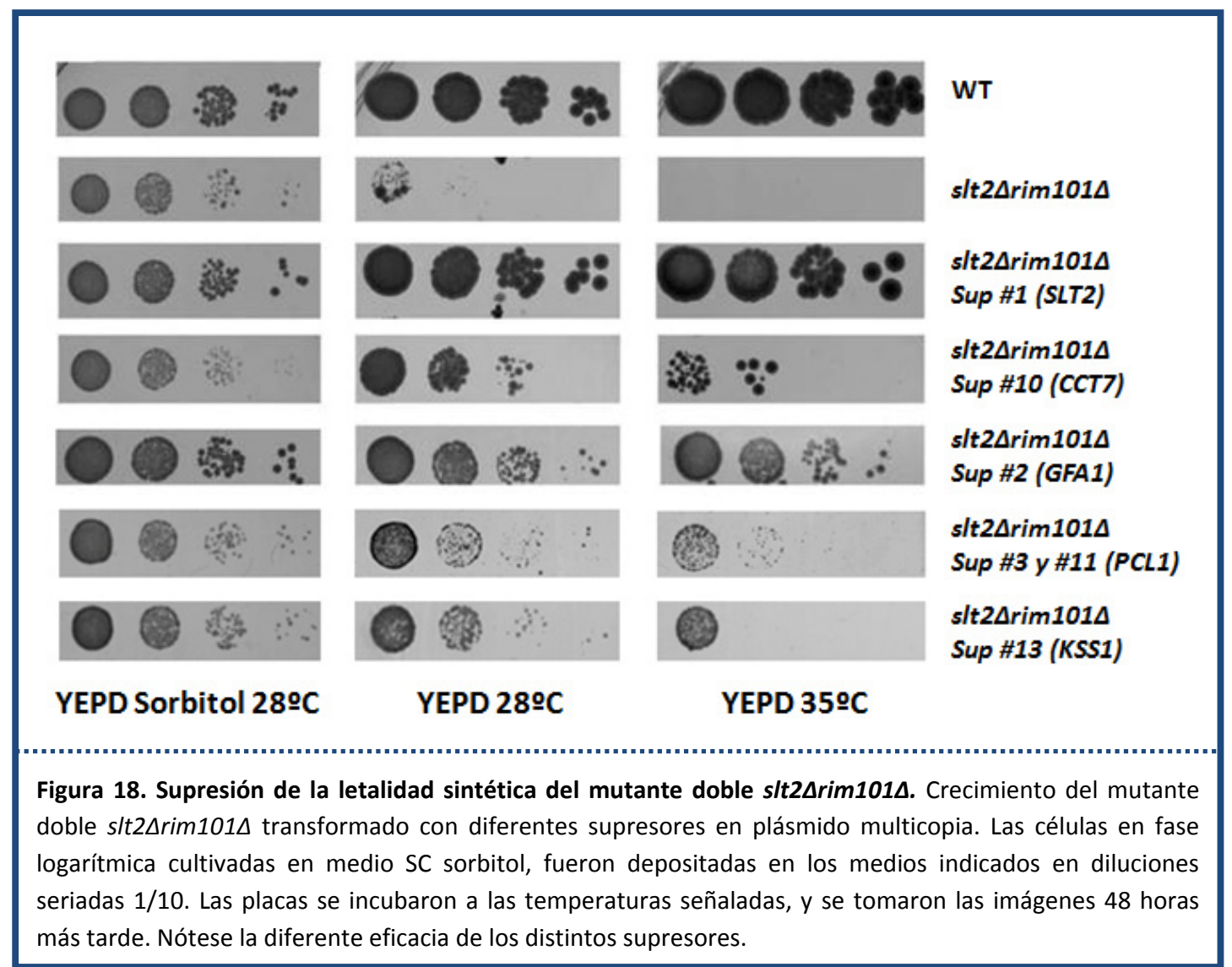

Entre todos los supresores, nuestros esfuerzos se centraron inicialmente en la caracterización de GFA1 y CCT7, ya que como se observa en la figura 18, son éstos los que permiten un mayor crecimiento a 28 y $35^{\circ} \mathrm{C}$. 


\subsection{La supresión mediada por GFA1: una cuestión de quitina}

Debido a los defectos en el ensamblaje de la pared celular observados en los mutantes dobles slt2 2 rim $\Delta$, el primer paso fue determinar los niveles y la localización de la quitina que presentaba la cepa slt2 $\Delta \operatorname{rim} 101 \Delta$. Cuando realizamos una tinción con calcoflúor durante 2-3 horas en medio suplementado con sorbitol, se observó una disminución notable en la señal fluorescente (Figura 19A), lo que sugirió que en el mutante

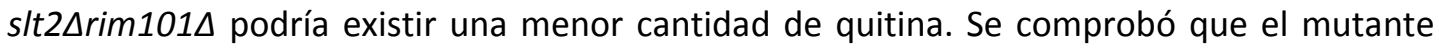
doble mostraba una disminución significativa de la misma cuando se analizó la cantidad de quitina presentada por este mutante, conteniendo aproximadamente la mitad de la quitina presente en la cepa silvestre (Figura 19B), lo que explicaba la menor tinción. Únicamente la combinación de ambas mutaciones podía explicar esta disminución en los niveles de este

A

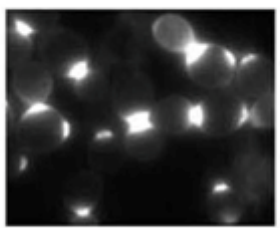

WT

B

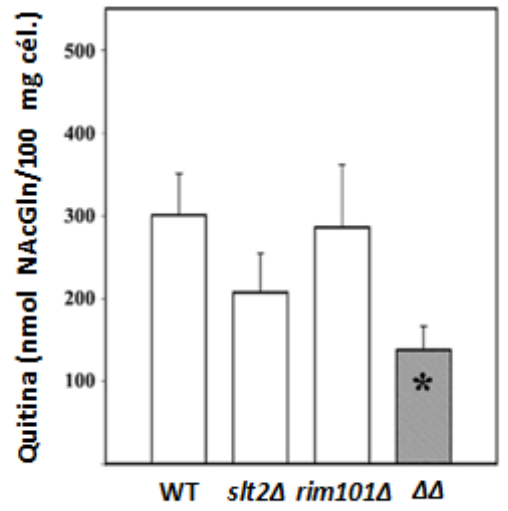

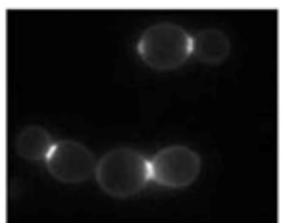

slt2 $\operatorname{rim} 101 \Delta(\Delta \Delta)$

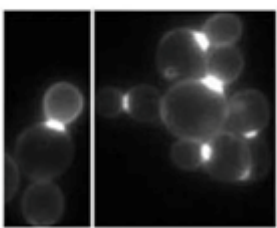

$\Delta \Delta+C C T 7$

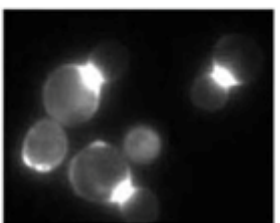

$\Delta \Delta+G F A 1$

C

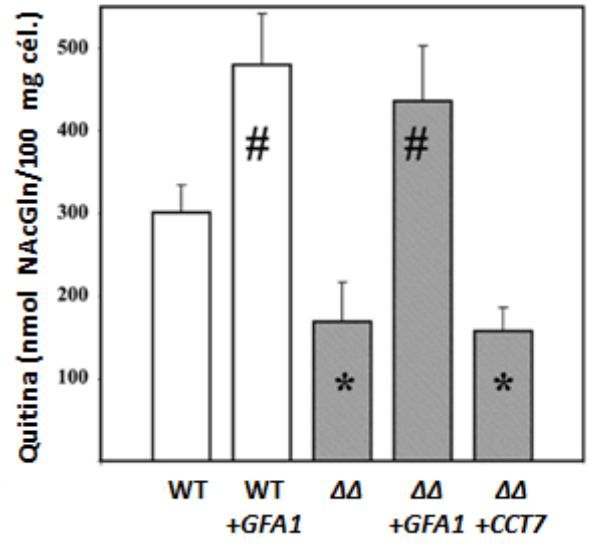

Figura 19. Síntesis de quitina. (A) Tinción de calcoflúor del mutante doble s/t2 $\Delta$ rim101 1 transformado con los plásmidos supresores YEp13-GFA1 y pRS424-CCT7. Se empleó la cepa silvestre (W303) como control. (B) y (C) Niveles de quitina (nmoles NAcGln/100 mg células) en las cepas señaladas. Los valores mostrados son la media de tres experimentos independientes, y se presenta la desviación estándar en cada caso. Los asteriscos indican valores significativamente $(P<0.05)$ diferentes a los de la estirpe silvestre. Los datos señalados con el símbolo almohadilla indican valores significativamente $(P<0.05)$ diferentes a los de la cepa silvestre o el mutante doble. 


\section{Resultados}

polímero, puesto que los mutantes simples slt2 $2 \Delta$ y rim $101 \Delta$ no presentaban una reducción significativa en los niveles de quitina al ser comparados con los de la cepa silvestre (Figura 19B).

De igual manera, decidimos comprobar cuáles eran los niveles que presentaban el

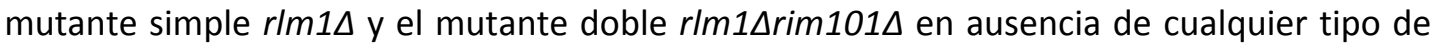
estrés sobre la pared celular. Se verificó que tanto el mutante $r / m 1 \Delta$ (tal y como se comentó anteriormente en la tabla 5) como el mutante doble $\operatorname{rm} 1 \Delta \operatorname{rim} 101 \Delta$ contenían cantidades muy similares a las de la estirpe silvestre (Figura 20), sin apreciarse los defectos

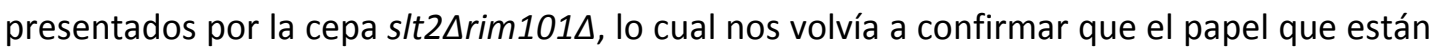
realizando la ruta PKC y la ruta RIM101 sobre la construcción de la pared celular es independiente de la respuesta transcripcional llevada a cabo por RIm1p.

Dados los significativos defectos en la síntesis de quitina del mutante s/t2 $\Delta \operatorname{rim} 101 \Delta$, quisimos determinar de forma preliminar si alguno de los genes aislados en el escrutinio era

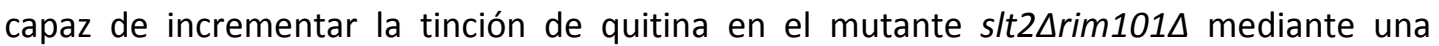
tinción con calcoflúor durante 2-3 horas. Tan sólo cuatro de los plásmidos conseguían intensificar esta fluorescencia. Dos de ellos contenían el gen SLT2, lo cual explicaba la recuperación total de los fenotipos, incluido el aumento de la tinción de quitina con calcoflúor (Datos no mostrados). Los otros dos plásmidos incluían los genes GFA1 y CCT7, promoviendo ambos un incremento notable en la tinción (Figura 19A).

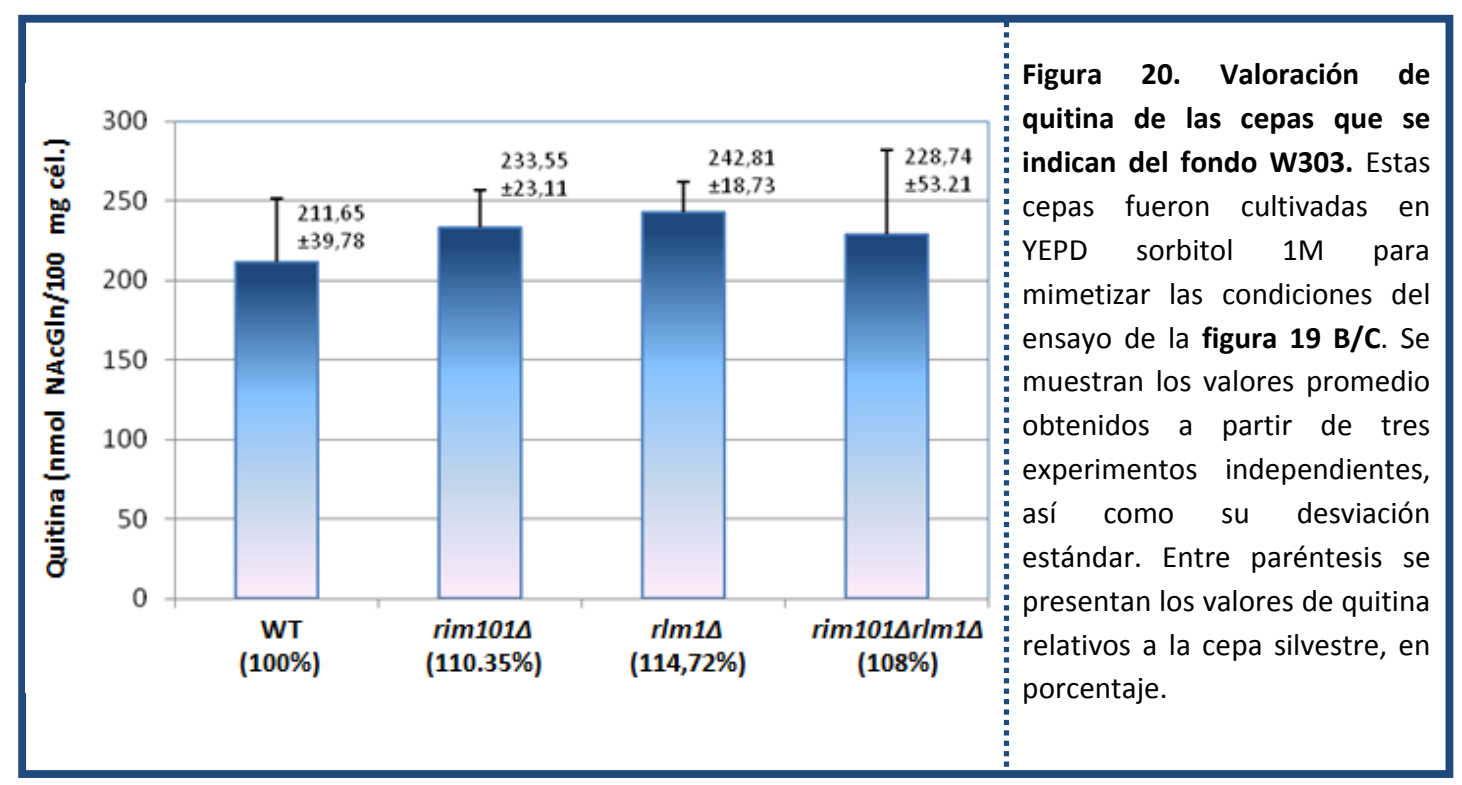


Gfa1p es una enzima requerida para la producción intracelular de la glucosamina-6fosfato, paso esencial en la producción de UDP-NAcGln, precursor metabólico de la quitina. Esta proteína actúa como cuello de botella en la regulación de la síntesis de la quitina, de tal forma que niveles aumentados o disminuidos de Gfa1p originan una mayor o menor síntesis de quitina respectivamente (Lagorce et al., 2003). Además, está descrito que la expresión de GFA1 se induce tras un daño producido sobre la pared celular, de forma dependiente a la ruta PKC (Lagorce et al., 2003; Garcia et al., 2004), relacionando así a priori a SLT2 con GFA1. Por otro lado, CCT7 codifica una subunidad del complejo de chaperoninas citosólicas denominado CCT (Stoldt et al., 1996) que está involucrado en múltiples procesos celulares, entre los que se encuentra el ensamblaje in vivo de proteínas como la actina y la tubulina (Kabir et al., 2005). Sin embargo nunca se la había relacionado con la síntesis de quitina, sugiriendo que la supresión llevada a cabo por GFA1 y CCT7 podría estar realizándose mediante dos mecanismos independientes.

Para comprobar esta hipótesis, determinamos cuantitativamente la cantidad de quitina que presentaban cultivos del mutante doble cuando se sobreexpresaban estos genes en condiciones normales de crecimiento. La sobreexpresión de GFA1 incrementaba

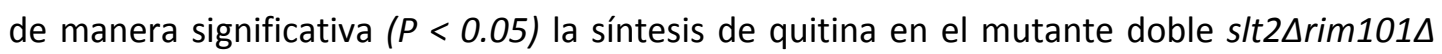
(Figura 19C). Al estudiar el efecto de GFA1 sobre la cepa silvestre también se observaba un incremento de los niveles de quitina $(P<0.05)$ (Figura 19C), algo ya conocido por estudios realizados anteriormente (Lagorce et al., 2002). Sin embargo, cuando determinamos los niveles de quitina presentes al sobreexpresar CCT7 en el mutante doble, se vio que no existía un incremento significativo en la síntesis de dicho polímero (Figura 19C). En S. cerevisiae, la mayoría de la quitina se deposita en forma de un anillo que rodea al cuello durante la división celular y que es sintetizado por la actividad QSIII (Shaw et al., 1991). Por ello analizamos la formación de este anillo mediante una tinción con calcoflúor de tan sólo cinco minutos sobre células fijadas previamente con formaldehído. Cuando se determinaron en el mutante doble el diámetro interno (Figura 21) y externo (Datos no mostrados) de los anillos de quitina, se comprobó que existía un incremento significativo ( $P$ < 0.05) del diámetro de ambos anillos respecto de los anillos observados en la cepa silvestre o en los mutantes simples, muy similares ambos al control. Por todos estos resultados, el mutante s/t2 $\Delta$ rim $101 \Delta$ aparentemente no consigue ensamblar el anillo de quitina de 
manera correcta, siendo esto una consecuencia específica de la contribución de las dos mutaciones.

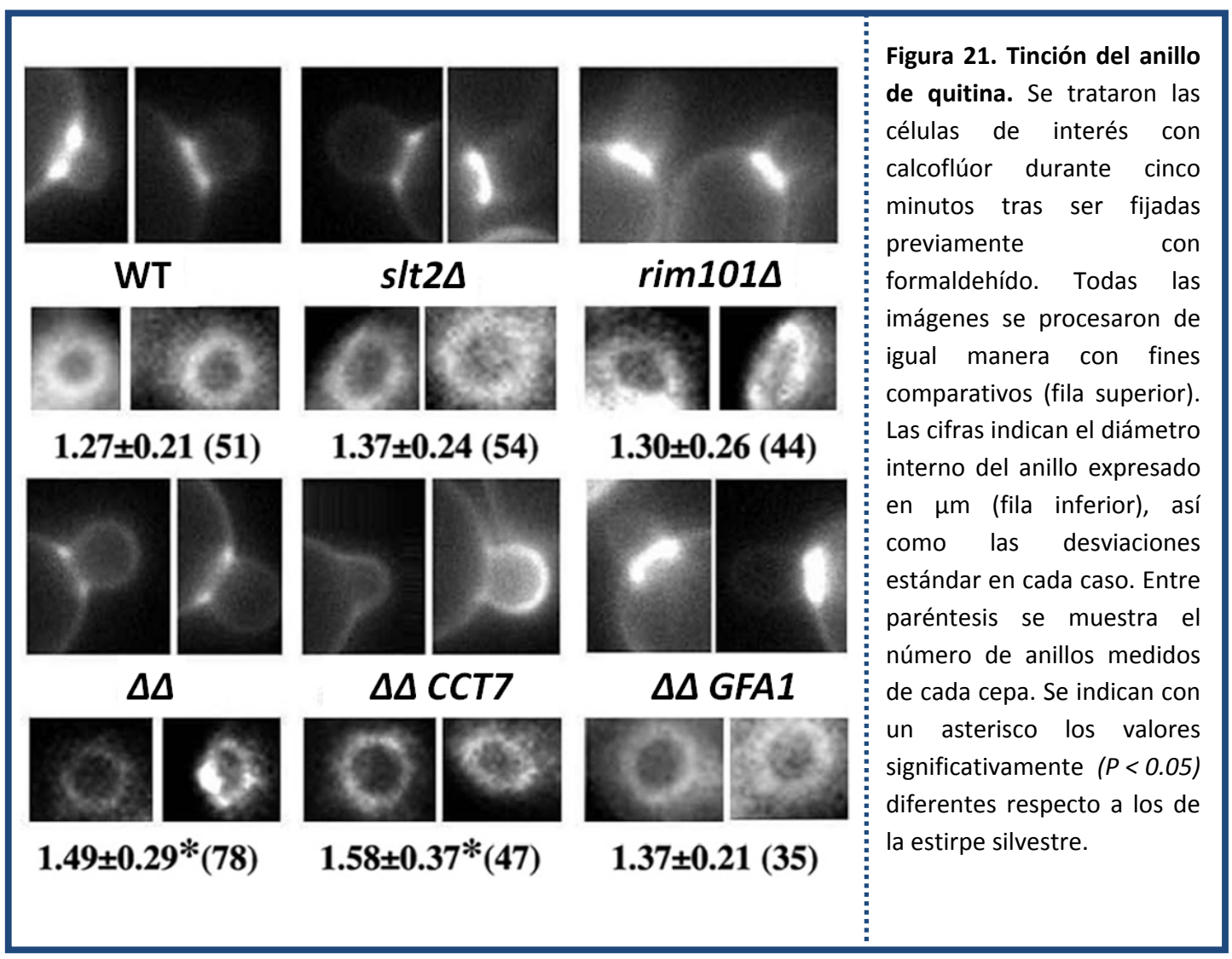

La supresión ejercida sobre el mutante doble por GFA1 se traducía en el restablecimiento del diámetro interno del anillo de quitina, alcanzando medidas similares a la cepa silvestre (Figura 21). Sin embargo, la supresión desempeñada por CCT7 ni incrementaba los niveles de quitina en ausencia de un estrés sobre la pared celular (Figura 19C), ni reducía de forma significativa el diámetro interno del anillo de quitina (Figura 21). Por ello, ambos genes llevan a cabo aparentemente la supresión sobre el mutante

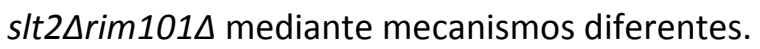

Los defectos descritos hasta ahora parecían estar relacionados, al menos de manera parcial, con un defecto en la actividad QSIII. Según nos muestra la supresión ejercida por GFA1, esto podría deberse simplemente a una disminución en la síntesis de los precursores de quitina. Por ello cuantificamos los niveles de expresión de GFA1 mediante un ensayo Northern blot en las cepas de interés. Los datos obtenidos nos muestran que los

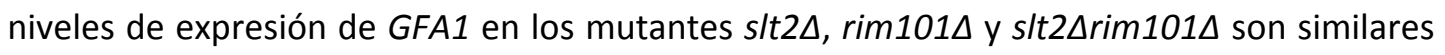


a los de la estirpe silvestre (Tabla 8). Por lo tanto, la síntesis reducida de quitina no parecía estar mediada por una disminución en la expresión de GFA1 y la consiguiente reducción de los niveles de los precursores metabólicos de la quitina.

\begin{tabular}{|c|c|c|c|}
\hline \multirow{2}{*}{ Cepas } & \multicolumn{2}{|c|}{ Expresión relativa } & \multirow{7}{*}{$\begin{array}{l}\text { Tabla 8. Niveles relativos de la } \\
\text { expresión de CTS1 y GFA1. La } \\
\text { expresión de ambos genes se } \\
\text { determinó mediante Northern blot, } \\
\text { empleándose la actina como control } \\
\text { de carga. Los valores mostrados } \\
\text { están referidos a la expresión } \\
\text { presentada por la cepa silvestre. Los } \\
\text { datos que se indican son la media de } \\
\text { tres experimentos independientes y } \\
\text { se indica la desviación estándar en } \\
\text { cada caso. }\end{array}$} \\
\hline & GFA1 & CTS1 & \\
\hline WT & 1 & 1 & \\
\hline slt2A & $1.26 \pm 0.10$ & $0.80 \pm 0.05$ & \\
\hline $\operatorname{rim} 101 \Delta$ & $1.35 \pm 0.09$ & $1.17 \pm 0.12$ & \\
\hline slt2Arim1014 & $1.48 \pm 0.58$ & $2.14 \pm 0.03$ & \\
\hline slt2 2 rim $101 \Delta+G F A 1$ & $86.02 \pm 0.60$ & $2.31 \pm 0.25$ & \\
\hline
\end{tabular}

Se ha descrito que tanto la sobreexpresión de GFA1 como la adición de glucosamina al medio de cultivo producen un aumento en la síntesis de quitina a través de un incremento de la actividad QSIII (Lagorce et al., 2002; Bulik et al., 2003). La adición de glucosamina $15 \mathrm{mM}$ medio YEPD elevó entre 3 y 4 veces los niveles de quitina tanto en la

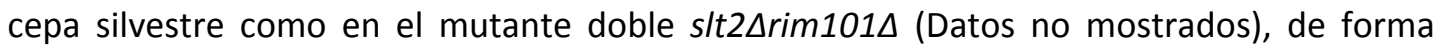
similar a lo que ocurre con la sobreexpresión de GFA1 (Figura 19C). Intentamos por lo tanto suprimir la letalidad del mutante doble mediante la adición al medio de cultivo de glucosamina a la misma concentración. Para ello realizamos un ensayo para determinar qué ocurría cuando, partiendo de unos cultivos que habían crecido en medio rico YEPD suplementado con sorbitol $1 \mathrm{M}$, se transferían a medio rico YEPD sin dicho estabilizador o con glucosamina añadida. Como puede verse en la figura $\mathbf{2 2}$, el mutante doble no crece en medio YEPD, pero muestra un crecimiento relativamente normal en el medio suplementado con glucosamina.

Para un análisis más detallado de estos resultados, procedimos a realizar los mismos experimentos en medio líquido (Figura 23). Como puede observarse, el paso del mutante doble a YEPD producía una lisis muy significativa del cultivo $(>40 \%)$, que no se observaba en el medio YEPD suplementado con glucosamina. Como ya hemos indicado, glucosamina y quitina están relacionados metabólicamente, por lo que analizamos directamente el efecto de la falta de la QSIII. El mutante triple slt2 2 rim $101 \Delta$ chs $3 \Delta$ se comportaba esencialmente como el mutante doble en YEPD sorbitol, y tampoco crecía 


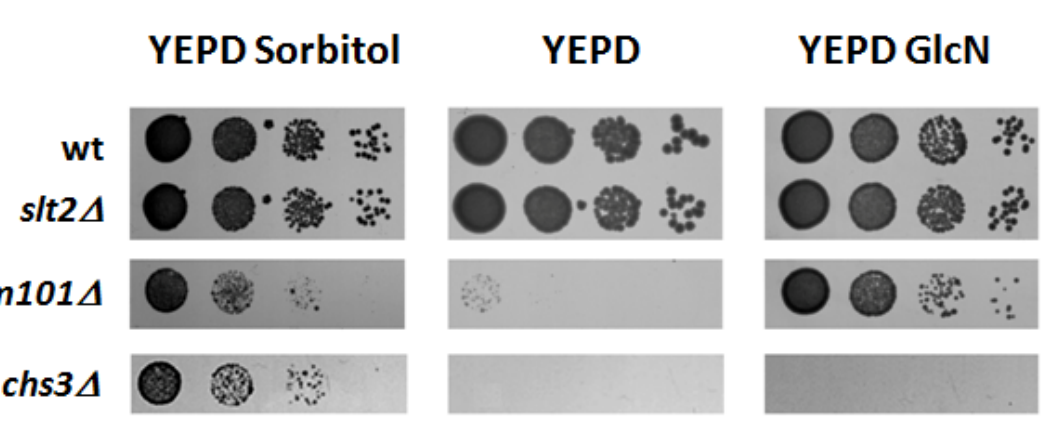

Figura 22. Efecto sobre el crecimiento de las cepas señaladas provocado por la adición de glucosamina $15 \mathrm{mM}$ al medio rico YEPD. Las células de los mutantes indicados cultivadas en YEPD sorbitol y en fase logarítmica, se transfirieron a los medios sólidos que se muestran, en diluciones seriadas $1 / 10$, y se incubaron las placas durante dos días a $28^{\circ} \mathrm{C}$.

al transferirlo a YEPD (>50\%) (Figura 22) debido al elevadísimo grado de lisis del cultivo

(Figura 23). Sin embargo este mutante triple era incapaz de crecer en YEPD glucosamina (Figura 22), ya que los niveles de lisis se mantenían muy altos, sin recuperarse éstos significativamente (Figura 23).

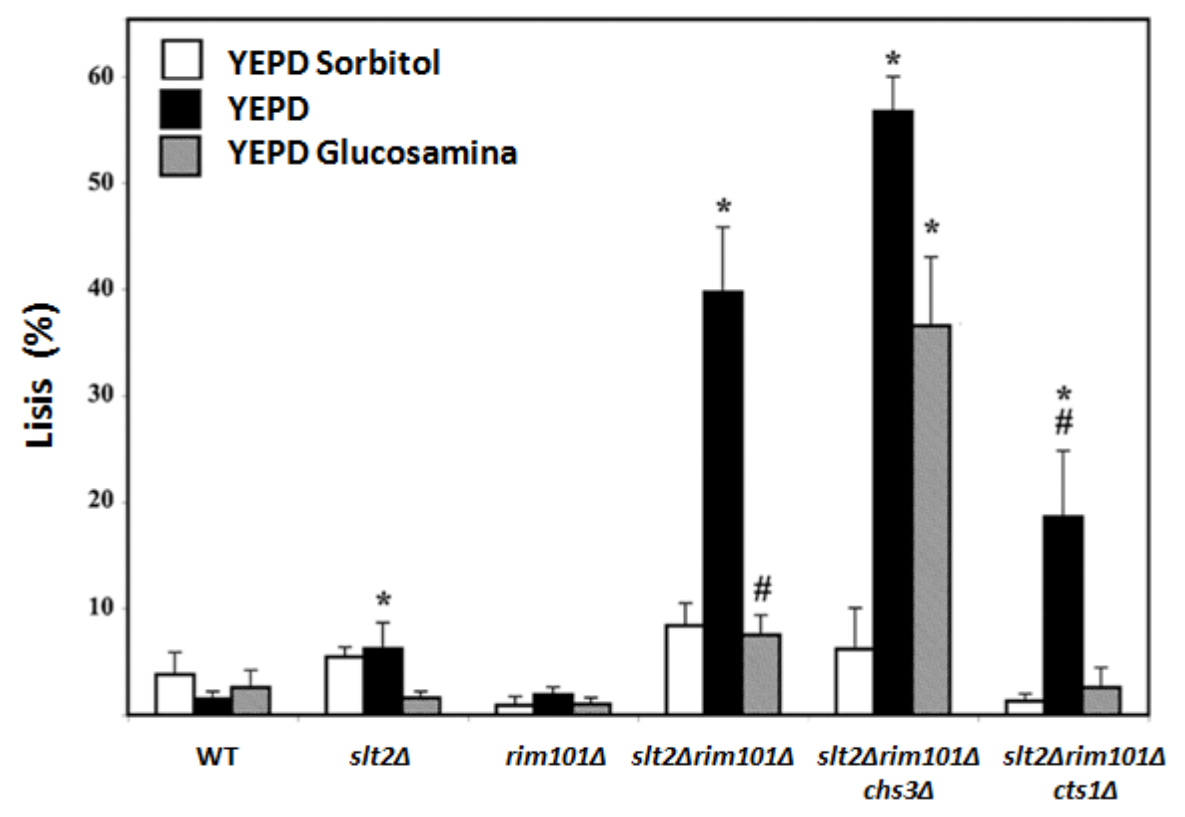

Figura 23. Cuantificación de la lisis al cambiar las cepas indicadas a un medio de cultivo líquido diferente. Se transfirieron células en fase logarítmica cultivadas en YEPD sorbitol $1 \mathrm{M}$ a los medios señalados. Tres horas después, se determinó la lisis mediante contaje de células refringentes observadas al microscopio de contraste de fases. La lisis viene indicada en porcentaje y los valores representados son la media de dos experimentos independientes, mostrándose también la desviación estándar correspondiente. Con asterisco se encuentran señalados los valores significativamente diferentes $(P<0.05)$ a los de la cepa silvestre en el mismo medio. El símbolo almohadilla indica una disminución significativa $(P<0.05)$ de la lisis comparada con la lisis que muestra el mutante doble en YEPD. 
Estos resultados ligan directamente la supresión por glucosamina, y muy probablemente la de GFA1, a la actividad QSIII, sugiriendo que la supresión es ejercida por un incremento en la actividad QSIII que promovería un ensamblaje más eficiente del anillo de quitina.

\subsubsection{Papel de CTS1 en la letalidad del mutante slt2 $\Delta$ rim $101 \Delta$}

Al observar al microscopio de contraste de fases las células de slt2 $\Delta$ rim $101 \Delta$ que habían sido transferidas a YEPD desde YEPD sorbitol 1M, comprobamos que la gran mayoría de la lisis afectaba sólo a las células hijas (Figura 24), que mostraban un aspecto refringente característico. Aproximadamente el $40 \%$ de la lisis ocurría exclusivamente en las células hijas, lo cual nos estaba sugiriendo que ésta estaría produciéndose en un estadío tardío del ciclo celular, posiblemente después de la separación física entre las células madre e hija. Mediante una tinción con azul de metileno se verificó que estas células refringentes eran realmente las que se encontraban lisadas (Datos no mostrados). Este fenotipo parecía bastante similar al originado por un desequilibrio entre las actividades enzimáticas de la actividad QSI y la endoquitinasa, descrito para el mutante chs1 en medios ácidos (Cabib et al., 1989).

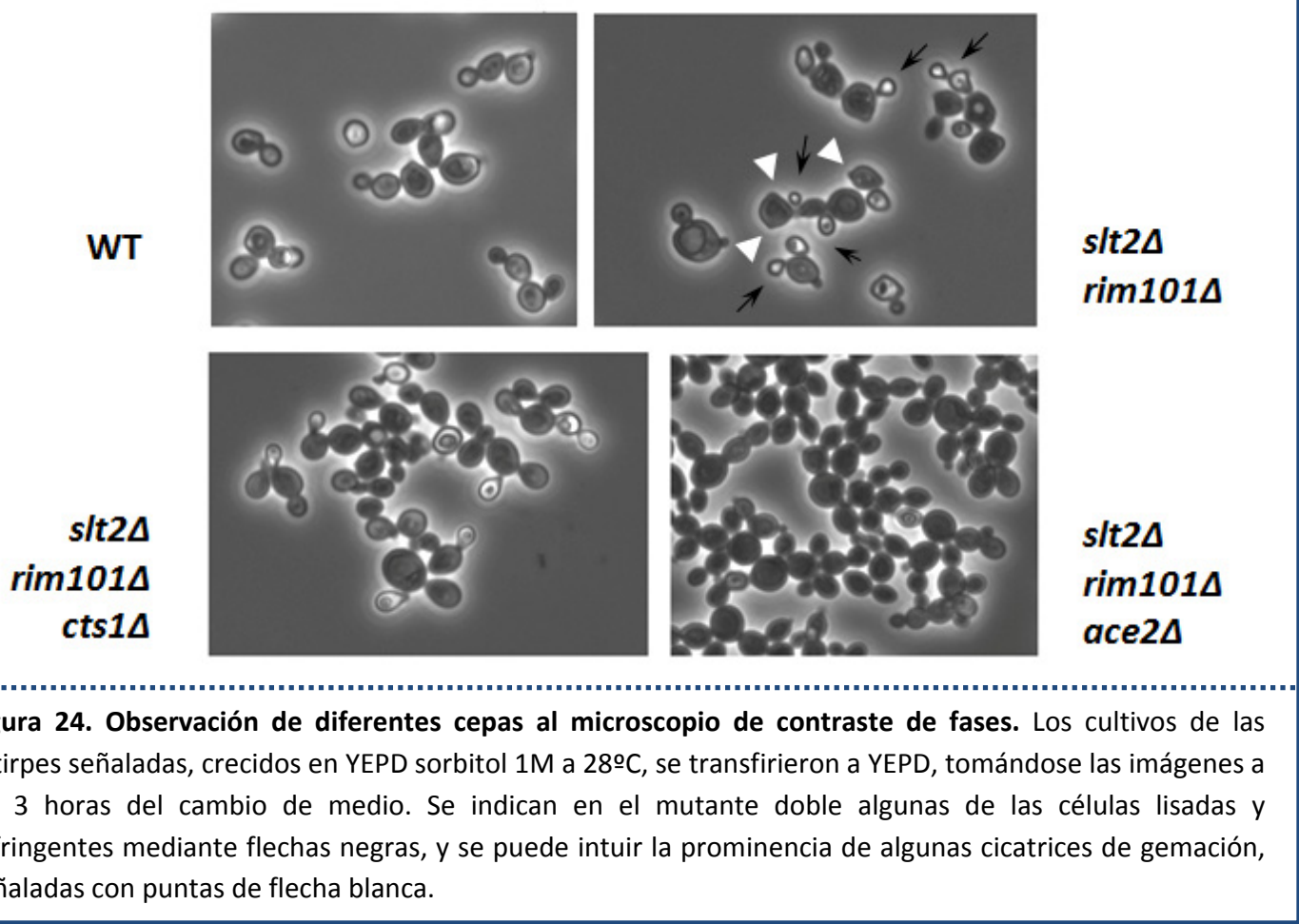




\section{Resultados}

Llegados a este punto intentamos determinar si este fenotipo de lisis del mutante

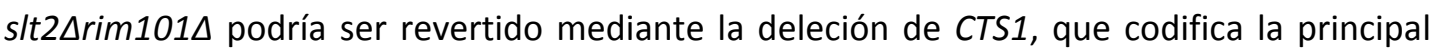
quitinasa de $S$. cerevisiae (Cabib et al., 1992), o bien mediante la sobreexpresión del gen CHS1, encargado de contrarrestar la excesiva actividad de la quitinasa durante el proceso de citoquinesis mediante un reforzamiento de quitina (Cabib et al., 1989). En primer lugar transformamos el mutante doble con el plásmido multicopia pRS424-CHS1, ya que su sobreexpresión conlleva un aumento muy significativo de la actividad QSI (Bulawa et al., 1986), haciendo a continuación un ensayo de gota para determinar el crecimiento de este transformante. Se demostró que el aumento en la actividad QSI no rescataba la letalidad de

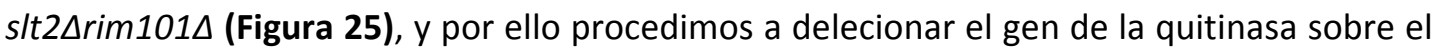
mutante doble. En este caso, el mutante triple slt2 $\Delta$ rim $101 \Delta$ cts $1 \Delta$ crecía razonablemente bien en YEPD sólido (Figura 25). Al estudiar el comportamiento de este mutante triple en medio líquido vimos que al ser transferido desde YEPD sorbitol 1M a YEPD, la lisis disminuía de manera significativa $(P<0.05)$ cuando se comparaba con la del mutante doble (Figura 23). A pesar de todo, cabe destacar que esta supresión era sólo parcial, ya que la lisis del

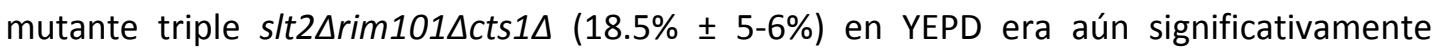
mayor $(P<0.05)$ que la observada en la cepa silvestre (Figura 23 ), como también puede verse en la figura 24. Esta disminución en la lisis permite explicar directamente el razonable

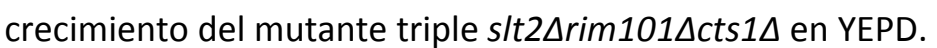

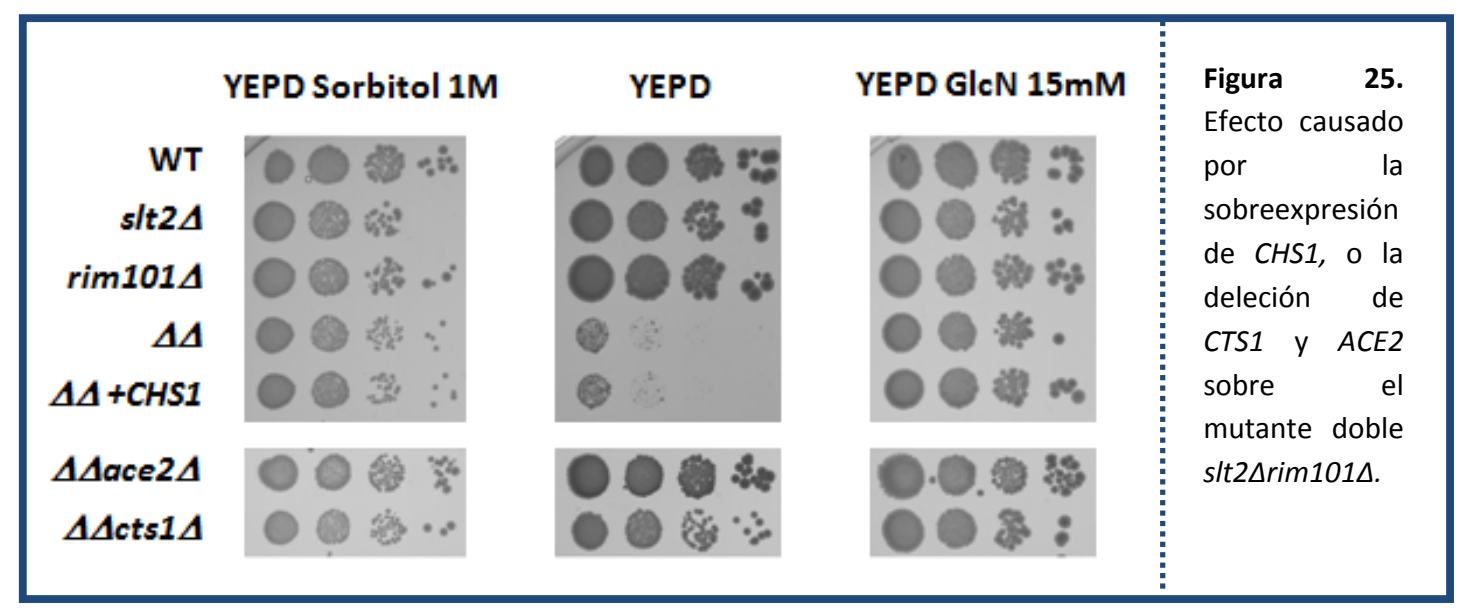

De acuerdo con el papel que posee RIM101 como represor transcripcional, uno de los 17 genes cuya expresión se encuentra aumentada dos o más veces en un mutante nulo rim101ム es la quitinasa CTS1 (Lamb \& Mitchell, 2003). Por ello determinamos mediante Northern blot los niveles de transcrito de dicho gen en las cepas de estudio (Tabla 8, página 
91). Aunque en nuestras manos tan sólo observamos un ligero aumento en la expresión de CTS1 en el mutante rim1014, sí observamos un incremento superior a 2 veces de la

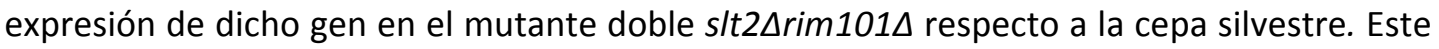
aumento apoya la idea de que un desequilibrio entre la síntesis y la degradación de la quitina en la zona del cuello del mutante doble podría originar la lisis del mismo y explicar así la letalidad sintética existente entre s/t2 $\Delta$ y rim $101 \Delta$ y todos los resultados presentados hasta el momento.

Para confirmar hasta qué punto el aumento de los niveles de CTS1 podría ser el causante del empeoramiento de los fenotipos de los mutantes, analizamos el efecto de la sobreexpresión de dicho gen en distintas cepas. Para ello transformamos el mutante slt2 $2 \Delta$ con el plásmido multicopia YEp352:CTS1, observamos su crecimiento en medio sólido YEPD en ausencia o presencia de sorbitol, y lo contrastamos con el correspondiente crecimiento

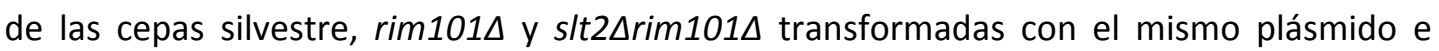
incubadas en las mismas condiciones (Figura 26). Cuando comparamos las cepas transformadas con sus respectivos controles, observamos que la sobreexpresión del gen de la quitinasa no tuvo ningún efecto sobre el crecimiento de la cepa silvestre ni en el mutante

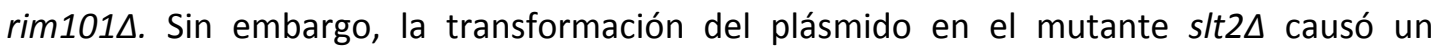
empeoramiento en su crecimiento, incluso en presencia de sorbitol. De forma adicional, el mutante doble s/t2 2 rim $101 \Delta$ también se vio afectado negativamente por la sobreexpresión de CTS1. Cabe destacar que la disminución del crecimiento del mutante s/t2 $\Delta$ en YEPD causada por la sobreexpresión de CTS1, no llegaba a igualarse al fenotipo letal del mutante doble s/t2Arim101, lo que nos indica que los problemas asociados a la deleción de RIM101 van más allá de la sobreexpresión de la quitinasa.

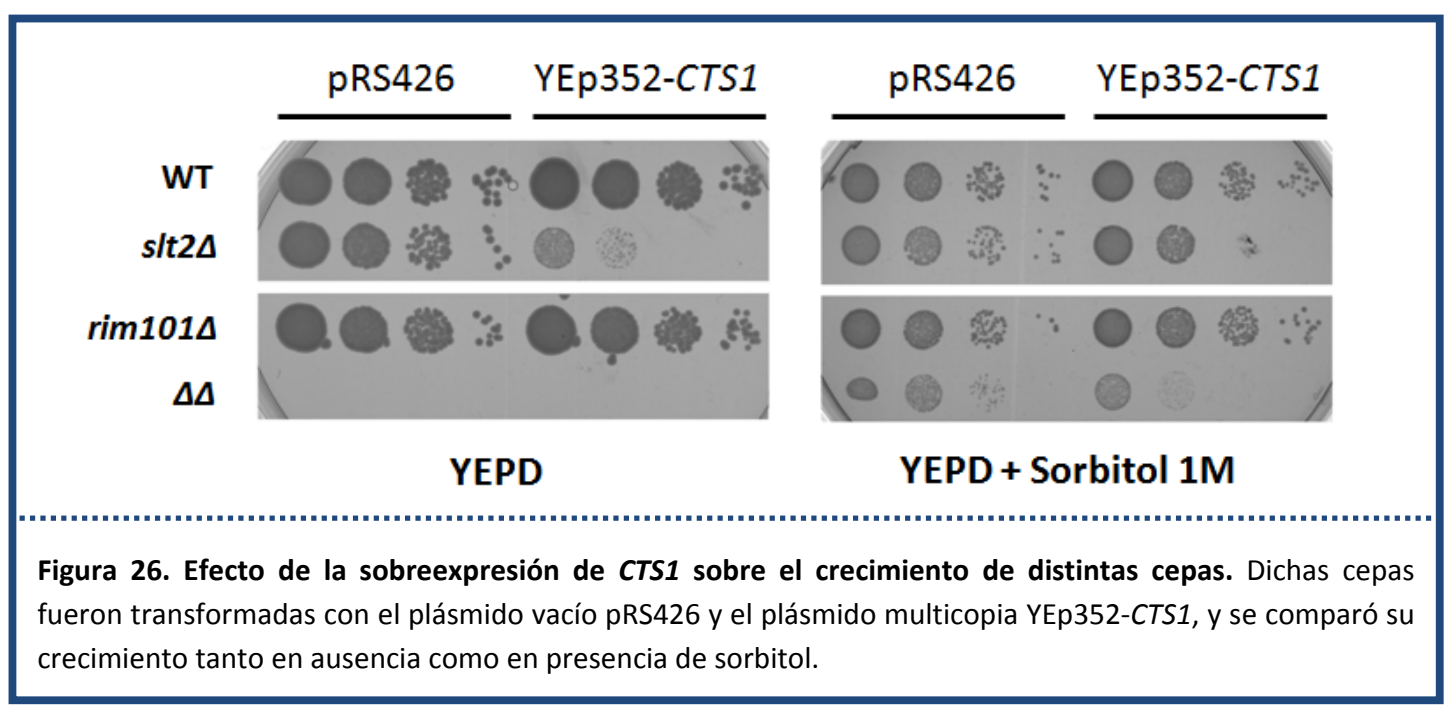


La expresión de CTS1 se encuentra regulada por el factor de transcripción Ace2p, que controla a su vez, entre otros, la expresión de genes específicos de la célula hija desde el núcleo de la misma (Colman-Lerner et al., 2001). Para comprobar si la deleción del gen ACE2 sobre el mutante doble era capaz de restaurar el crecimiento del mismo, construimos

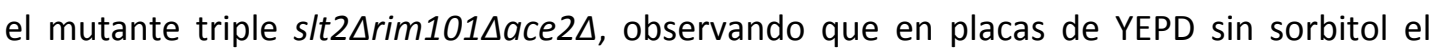
crecimiento de esta cepa era comparable al de la cepa silvestre. Cuando observamos al microscopio de contraste de fases células de este mutante crecidas en medio líquido YEPD, su aspecto nos confirmaba que la lisis era tan sólo residual $(<5 \%, n=300)$. Tanto las células de este mutante triple como las del mutante s/t2 $\Delta$ rim $101 \Delta c t s 1 \Delta$ muestran un fenotipo con defectos en la separación celular (Figura 24) (Kuranda \& Robbins, 1991; Dohrmann et al., 1992), originando agrupaciones de células. La lisis presentada por el mutante triple

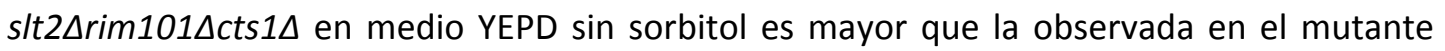

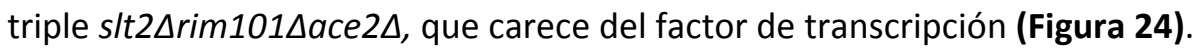

A continuación quisimos analizar si existía una localización anómala de Ace2p en el

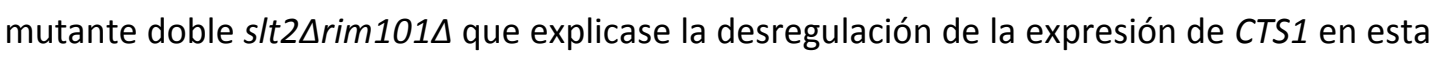
cepa. Aparentemente la localización de la proteína marcada con el epítopo YFP no se

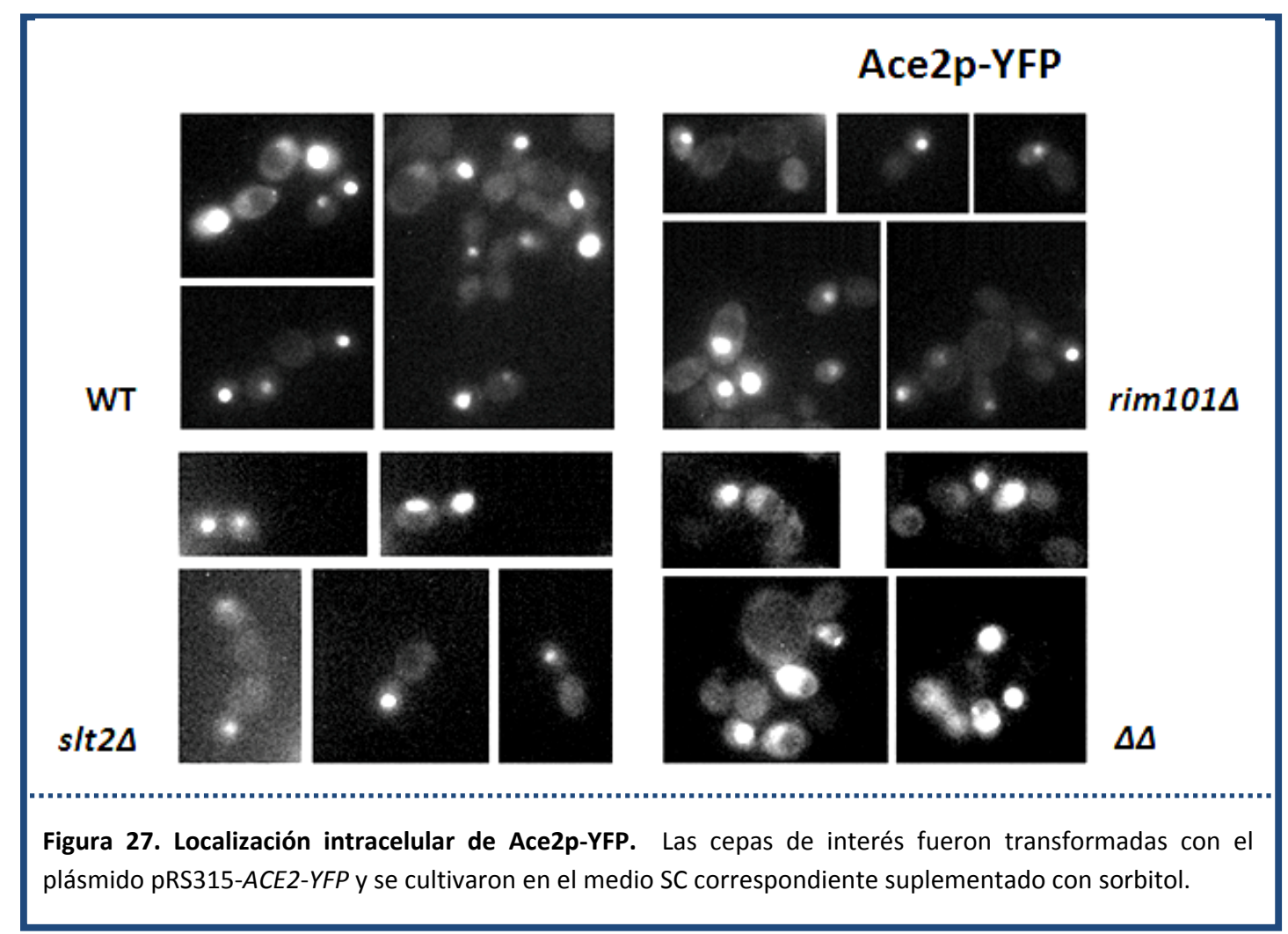


encontraba afectada, puesto que en todas las cepas la proteína se localizaba mayoritariamente en el núcleo de la célula hija (Figura 27), como se ha descrito previamente. Estos resultados sugieren que, además de CTS1, otros genes regulados por

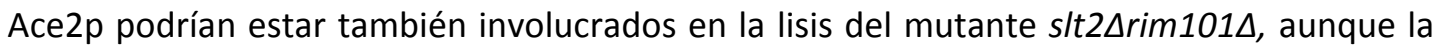
supresión ejercida por el mutante ace2 $\Delta$ podría ser también ejercida a través de la alteración del ciclo celular descrita para este mutante.

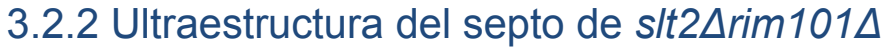

Todos los datos obtenidos hasta el momento apuntan a un ensamblaje alterado del septo a nivel de la región del cuello durante la división celular, donde la actividad QSIII está involucrada en la construcción del anillo de quitina, y la quitinasa CTS1 actúa para promover la separación celular. Para estudiar en mayor profundidad esta posibilidad, realizamos microscopía electrónica de transmisión para observar la zona de interés. Se

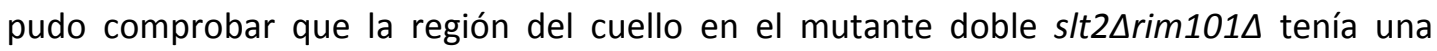
apariencia más tubular o cilíndrica que en la cepa silvestre (Figura 28), siendo éste un fenotipo ya descrito en el mutante chs3山 (Schmidt et al., 2003). Este fenotipo está ligado a una aparente fragilidad de la pared del cuello. Asimismo, las cicatrices de gemación son más prominentes, hecho que ya habíamos observado al microscopio de contraste de fases (Figura 24), y que estaba descrito también para los mutantes bni4 $\Delta$ y chs3 $\Delta$ (Sanz et al., 2004). El mutante doble es capaz de formar septos primarios, aunque éstos aparecían desplazados hacia la célula hija y eran más irregulares que en el resto de cepas control. Todos estos defectos no se apreciaban en los mutantes sencillos slt2 $\Delta$ y rim $101 \Delta$, que presentaban una morfología bastante normal, lo cual corroboraba que la combinación de ambas mutaciones era la causa de los graves problemas de estructura a nivel del cuello. Cabe destacar que la sobreexpresión de GFA1 sobre el mutante doble era capaz de restablecer la arquitectura normal del septo, observándose tanto septos primarios como cuellos con un aspecto típicamente silvestre (Figura 28).

Sin embargo, la deleción de CTS1 sobre el mutante doble no mejoraba ninguno de estos defectos, indicándonos que el exceso de quitinasa sintetizada no estaba directamente relacionado con los fenotipos observados en la estructura del cuello, sino específicamente con el aumento de la lisis celular. Hay que añadir que, a la vista de las imágenes de 

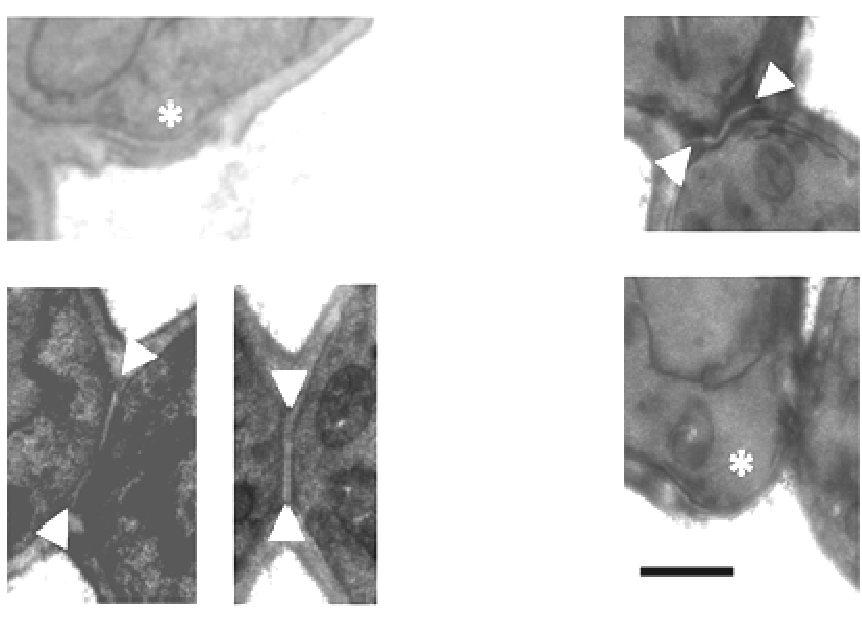

WT

$s / t 2 \Delta$
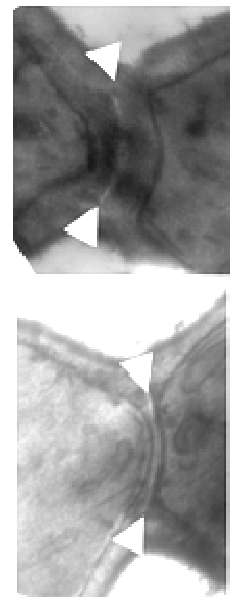

rim1010
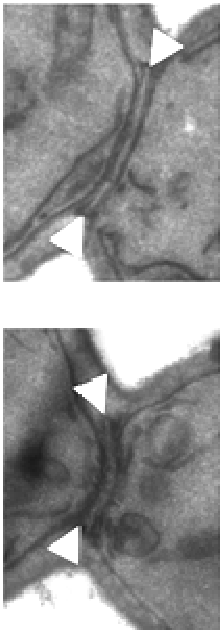

s/t2 2 rim $101 \Delta$

+GFA1
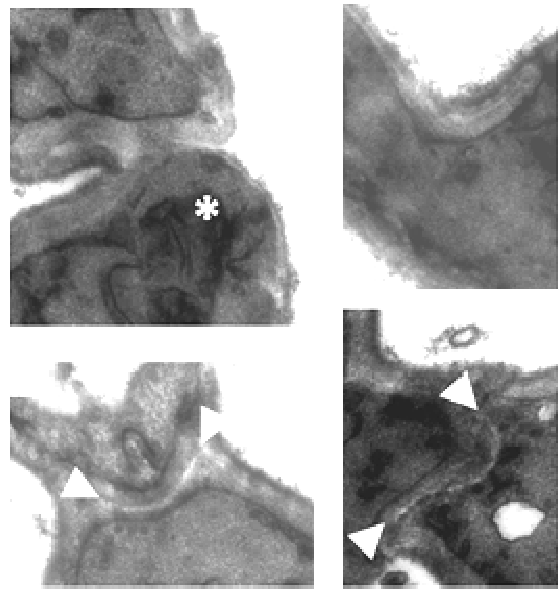

slt2Arim1010
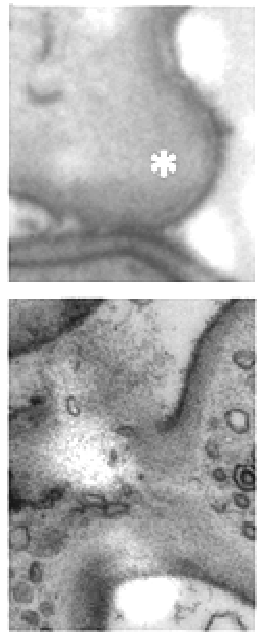

slt20rim 1010 chs $3 \Delta$
Figura 28. Ultraestructura del septo en las cepas indicadas obtenidas mediantes microscopía electrónica de transmisión. El septo primario se encuentra señalado con puntas de flecha blanca, mientras que las cicatrices de gemación se indican mediante asteriscos. Nótese la aparente fragilidad de la pared del cuello en algunos mutantes. La barra de medida (presente en el panel del mutante s/t2 $\Delta$ ) representa $0.5 \mu \mathrm{m}$ 
microscopía electrónica, el mutante slt2 $\Delta \operatorname{rim} 101 \Delta c h s 3 \Delta$ presentaba la zona del septo tremendamente debilitada, sugiriendo que la lisis se llevaba a cabo fundamentalmente en ese área. Esto era lo esperado, teniendo en cuenta que este mutante posee los problemas ocasionados por la ausencia conjunta de SLT2 y de RIM101, además de carecer totalmente del anillo de quitina, que es imprescindible junto con el anillo de septinas para mantener la integridad del cuello en esta levadura (Schmidt et al., 2003). Al igual que en el mutante

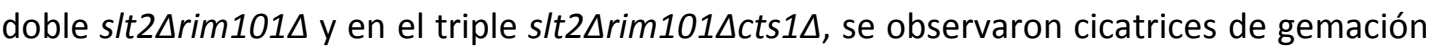
muy prominentes en el mutante triple slt2 $\Delta \operatorname{rim} 101 \Delta \operatorname{chs} 3 \Delta$, que son consecuencia del desplazamiento aparente del septo primario hacia la célula hija (Figura 28).

Todos los resultados presentados relacionan claramente los defectos del mutante slt2 2 rim $101 \Delta$ con defectos en el ensamblaje del anillo de quitina, reforzando la visión que se tenía del papel homeostático de este anillo en el mantenimiento de la integridad celular durante la citoquinesis (Lesage et al., 2005). Sin embargo desconocíamos todavía cuáles eran las causas moleculares exactas de estos defectos.

\subsection{El ensamblaje de la maquinaria del cuello en ausencia de SLT2 y RIM101}

Los resultados presentados hasta el momento indican claros defectos en el ensamblaje de la maquinaria del cuello, que se traducen en las alteraciones del septo observadas. Sin embargo, no estaban claras las causas moleculares de estos defectos, por lo que nos centramos en estudiar posibles defectos concretos.

\subsubsection{Ensamblaje del complejo QSIII}

En S. cerevisiae, la actividad QSIII depende de la correcta llegada de Chs3p a la membrana plasmática en la zona del cuello, y éste es un proceso dependiente de Chs $4 \mathrm{p}$. Chs $4 p$ es necesaria por un lado para producir la activación de la actividad QSIII, y por tanto para la síntesis de quitina, y por otro es esencial para la correcta localización de Chs3p en la zona del cuello (DeMarini et al., 1997; Kozubowski et al., 2003; Sanz et al., 2004; Reyes et al., 2007). Por ello nos interesaba determinar la localización intracelular de Chs3p y Chs4p. Ambas proteínas mostraron una localización similar en la zona del cuello en los mutantes simples s/t2 y rim $101 \Delta$ cuando se comparó con la cepa silvestre (Figura 29). 


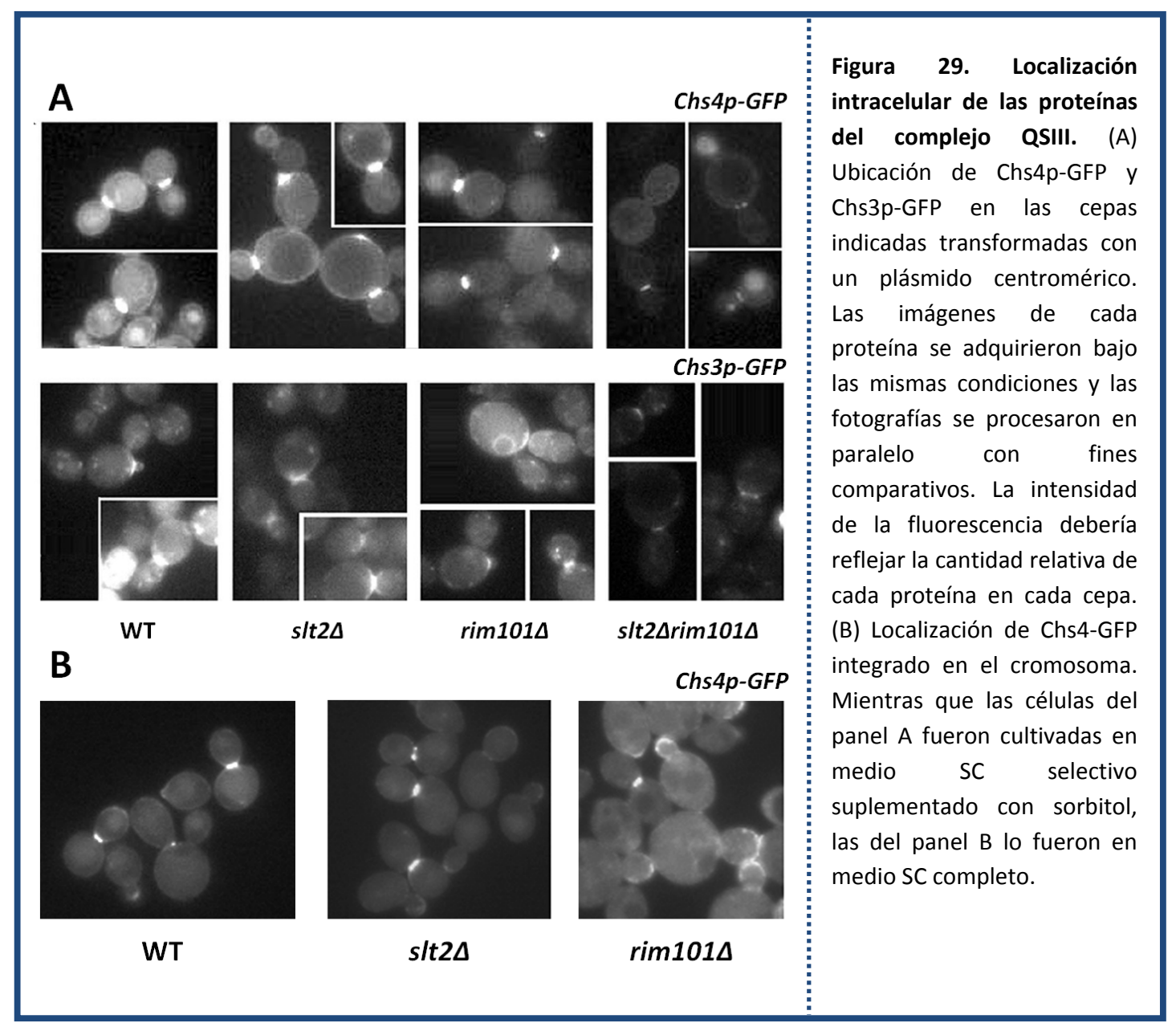

Sin embargo, las señales de Chs3p-GFP y Chs4p-GFP en el cuello del mutante doble

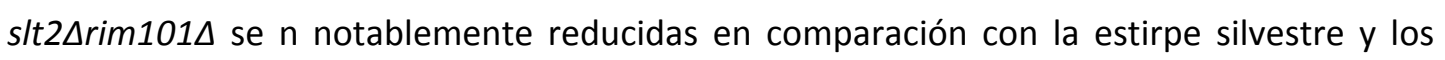
mutantes simples (Figura 29A), hecho que podría explicar el defecto en la formación del anillo de quitina observado en este mutante. Este defecto podría estar causado por una cantidad menor de estas proteínas o por un anclaje incorrecto del complejo QSIII a la maquinaria del septo, por lo que quisimos analizar ambas posibilidades.

Para determinar los niveles proteicos, analizamos la cantidad de Chs4p-GFP y Chs3p-GFP mediante Western blot. Como puede observarse, los niveles de Chs4p-GFP (Figura 30A), pero no los de Chs3p-GFP (Figura 30B), estaban significativamente reducidos en el mutante doble, presentando los mutantes simples niveles de proteínas similares al control en ambos casos. 


\section{A $\begin{array}{llllll} & \text { WT } & s / t 2 \Delta & \operatorname{rim} 101 \Delta & \Delta \Delta \\ \text { Chs4p-GFP } & & & & \\ & & & & \\ & 1 & 0.66 \pm 0.06 & 0.72 \pm 0.06 & 0.19 \pm 0.01\end{array}$ \\ B Chs3p-GFP WT slt2s $\operatorname{rim} 101 \Delta \quad \Delta \Delta$ Tubulina \\ $1 \quad 0.71 \pm 0.07 \quad 1.04 \pm 0.03 \quad 0.74 \pm 0.02$ \\ Tubulina \\ Figura 30. Niveles de Chs4p-GFP (A) y Chs3p-GFP (B). Se determinó la cantidad de estas proteínas mediante Western blot. Las cifras indican los niveles relativos de Chs4p-GFP o Chs3p-GFP empleando la tubulina como control de carga. Los datos presentados son la media de dos experimentos independientes, mostrándose a su vez la desviación estándar. Las cepas fueron cultivadas en el correspondiente medio SC selectivo suplementado con sorbitol.}

Un análisis más detallado de la localización de Chs4p-GFP nos indicó que tanto las células del mutante simple rim101ム como las del mutante doble mostraban una ausencia de la señal a lo largo de la membrana plasmática, cuya señal podía observarse tanto en la estirpe silvestre como en el mutante s/t2 $\Delta$ (Figura 29B). Esta distribución recordaba a la que poseen células que presentan formas no preniladas de la proteína Chs4p (Reyes et al., 2007), lo que nos estaba sugiriendo que la ausencia de Rim101p podría estar alterando la localización intracelular de Chs4p. Cuando utilizamos una versión integrada de Chs4p marcada con GFP, en lugar de usar el plásmido pRS314-CHS4-GFP, confirmamos este efecto causado por la deleción de RIM101. En el mutante rim1014, Chs4p-GFP se encontraba deslocalizada hacia la yema (Figura 29B), con un número de yemas que mostraban fluorescencia bastante mayor $(38.5 \pm 0.7, n=102)$ que el observado al analizar la estirpe silvestre $(12.2 \pm 3.4, n=196)(P<0.05)$. Estos datos nos indicaban una funcionalidad limitada de Chs4p que podría explicar el escaso acúmulo de Chs3p en el cuello, y por lo tanto, los

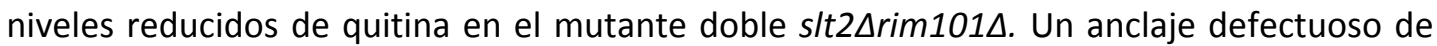
Chs $4 p$ a la membrana podría favorecer una mayor degradación de la proteína, tal y como ya ha sido descrito anteriormente (Reyes et al., 2007) y se puede observar en el mutante slt2 $\operatorname{rim} 101 \Delta$. 


\subsubsection{Participación de RSB1 en los defectos de rim101ム}

Recientemente se ha descrito que el gen denominado RSB1 es requerido para mantener la homeostasis de la asimetría de lípidos de membranas en levaduras cuando se produce una alteración en la misma (Ikeda et al., 2008), y su expresión se encuentra disminuida en los mutantes que carecen del factor de transcripción RIM101 (Lamb \& Mitchell, 2003). Esta asimetría de lípidos desempeña un papel fisiológico que no está claro hasta la fecha, pudiendo afectar a la asociación de múltiples proteínas a membranas. Tal y como se ha detallado, Chs $4 p$ se encontraba ausente en la periferia de la membrana plasmática y se acumulaba de forma anormal en las yemas en los mutantes rim101ム (Figura 29B), de forma similar a lo que ocurre con las formas no preniladas de Chs $4 p$, que no son capaces de asociarse por sí misma a las membranas. Por ello quisimos examinar hasta qué punto RSB1 podría estar implicado en estos defectos observados en la cepa rim101A. Para

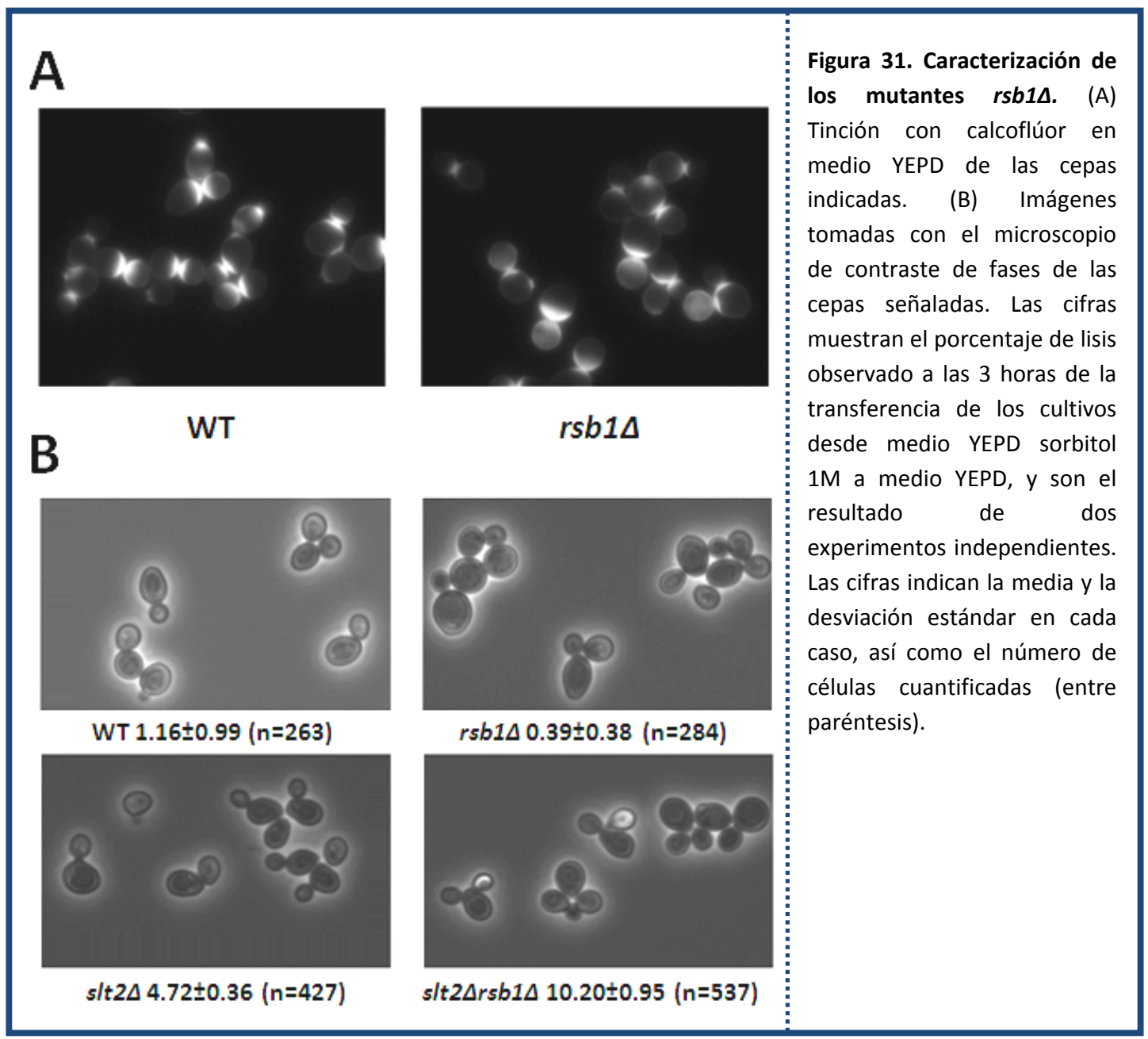


ello se llevó a cabo una tinción con calcoflúor para examinar la localización de la quitina, observando que ésta se encontraba parcialmente deslocalizada en el mutante $r s b 1 \Delta$ (Figura 31A), algo que ya habíamos observado previamente en el mutante rim101ム. Además construimos el mutante doble $s / t 2 \Delta r s b 1 \Delta$ en dos fondos genéticos diferentes, y a diferencia

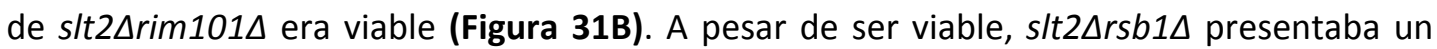
nivel significativo de lisis al cultivarse en medio líquido YEPD sin sorbitol. Esto nos permitía relacionar algunos de los defectos presentados por el mutante rim $101 \Delta$ con el descenso de los niveles de RSB1 debido a la ausencia de RIM101. La desregulación de RSB1 podría estar directamente relacionada con la deslocalización de Chs4p observada, aunque podría manifestar sus efectos indirectamente a través de otras proteínas implicadas en el ensamblaje del cuello.

\subsubsection{Localización de las proteínas de la maquinaria de septación y papel de CCT7 como supresor}

En S. cerevisiae está descrita la colocalización de Chs3p y Chs4p en el cuello. Chs4p, gracias a su unión al anillo de septinas a través de la proteína intermediaria Bni4p, es la que permite la localización de la QSIII en el cuello (DeMarini et al., 1997; Sanz et al., 2004). Por lo tanto, el acúmulo de QSIII en esta zona depende en última instancia de la maquinaria de septación. Por ello nos centramos en el estudio de la localización de las proteínas Bni4p, la septina Cdc3p y la miosina Myo1p. MYO1 codifica una miosina de tipo II (Brown, 1997) que forma parte del anillo de actomiosina, jugando un papel crítico en la separación celular, además de estar directamente involucrada en la formación del septo primario.

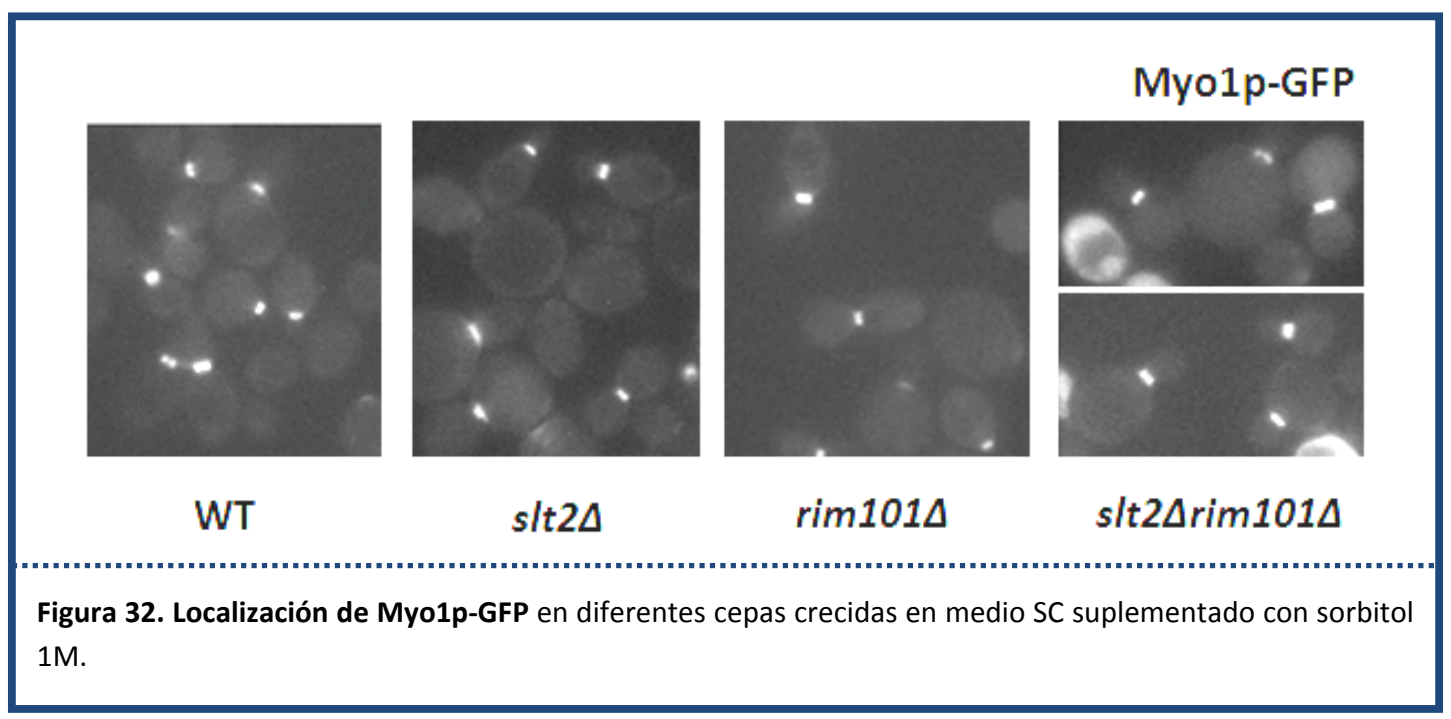




\begin{tabular}{|c|c|c|c|c|c|c|}
\hline CEPAS & WT & Bni4p-YFP & \{\} & ${ }^{W T_{r}}{ }_{\text {, }}$ & Myo1p-GFP & $\Delta \Delta \otimes^{\Upsilon}$ \\
\hline WT & \multicolumn{3}{|c|}{$1.401 \pm 0.167(100 \%)(127)$} & \multicolumn{3}{|c|}{$1.101 \pm 0.080(100 \%)(112)$} \\
\hline slt2Arim1010 & \multicolumn{3}{|c|}{$1.766 \pm 0.193^{*}(126 \%)(172)$} & \multicolumn{3}{|c|}{$1.106 \pm 0.042(100 \%)(130)$} \\
\hline
\end{tabular}

Tabla 9. Distribución de Bni4p-YFP y Myo1p-GFP. Las cifras indican la anchura de la marca de fluorescencia de dichas proteínas en el cuello de las cepas señaladas. Los valores están expresados en $\mu \mathrm{m}$ y son la media de tres experimentos independientes, indicándose la desviación estándar en cada caso. Entre paréntesis se muestra el número de células utilizadas para el recuento, teniéndose en cuenta sólo aquéllas con un enfoque nítido. Se señala con un asterisco aquel valor significativamente $(P<0.05)$ diferente al de la estirpe silvestre.

La localización de Myo1p-GFP es similar en todas las cepas estudiadas (Figura 32), incluyendo en el mutante doble slt2 $\Delta \operatorname{rim} 101 \Delta$, lo cual permitiría la síntesis normal del septo primario, tal y como se ha podido observar anteriormente en las imágenes de microscopía electrónica (Figura 28). Además de localizarse correctamente, la anchura del anillo de actomiosina era similar en todas las estirpes (Tabla 9). CDC3 es un gen esencial cuyo producto, la septina Cdc3p, es imprescindible en la formación del anillo de septinas. Este anillo es requerido para la citoquinesis en muchas especies, incluyendo la levadura $S$. cerevisiae (Longtine et al., 1996). La localización de Cdc3p fusionada a la proteína verde fluorescente era similar en los mutantes simples y en la cepa silvestre, con un porcentaje de células en torno al 50\% mostrando un anillo doble (Figura 33A y Tabla 10). Sin embargo, el

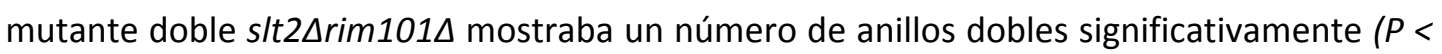
0.05) reducido (Tabla 10), como se comprueba también en las imágenes. Al observar más en detalle la señal de Cdc3p-GFP en las células de los mutantes sencillos, pudimos constatar

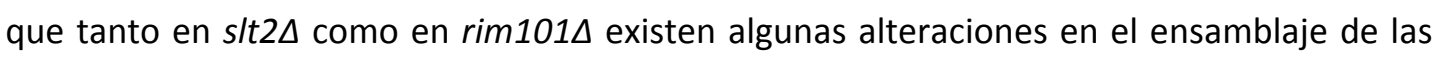
septinas. Mientras que los cultivos de la estirpe silvestre mostraban un escaso número de células con dobles anillos asimétricos, éstos se incrementaban significativamente $(P<0.05)$ tanto en los mutantes sencillos como en el mutante doble (Figura 33B), sugiriendo un papel para SIt2p y Rim101p en el control del ensamblaje de septinas. Es interesante el hecho de que el anillo de septinas controla la distribución asimétrica de algunas proteínas del cuello durante la división celular (Kozubowski et al., 2005), y entre ellas se encuentra Bni4p, una proteína clave en la localización de Chs4p (Kozubowski et al., 2003; Sanz et al., 2004). 


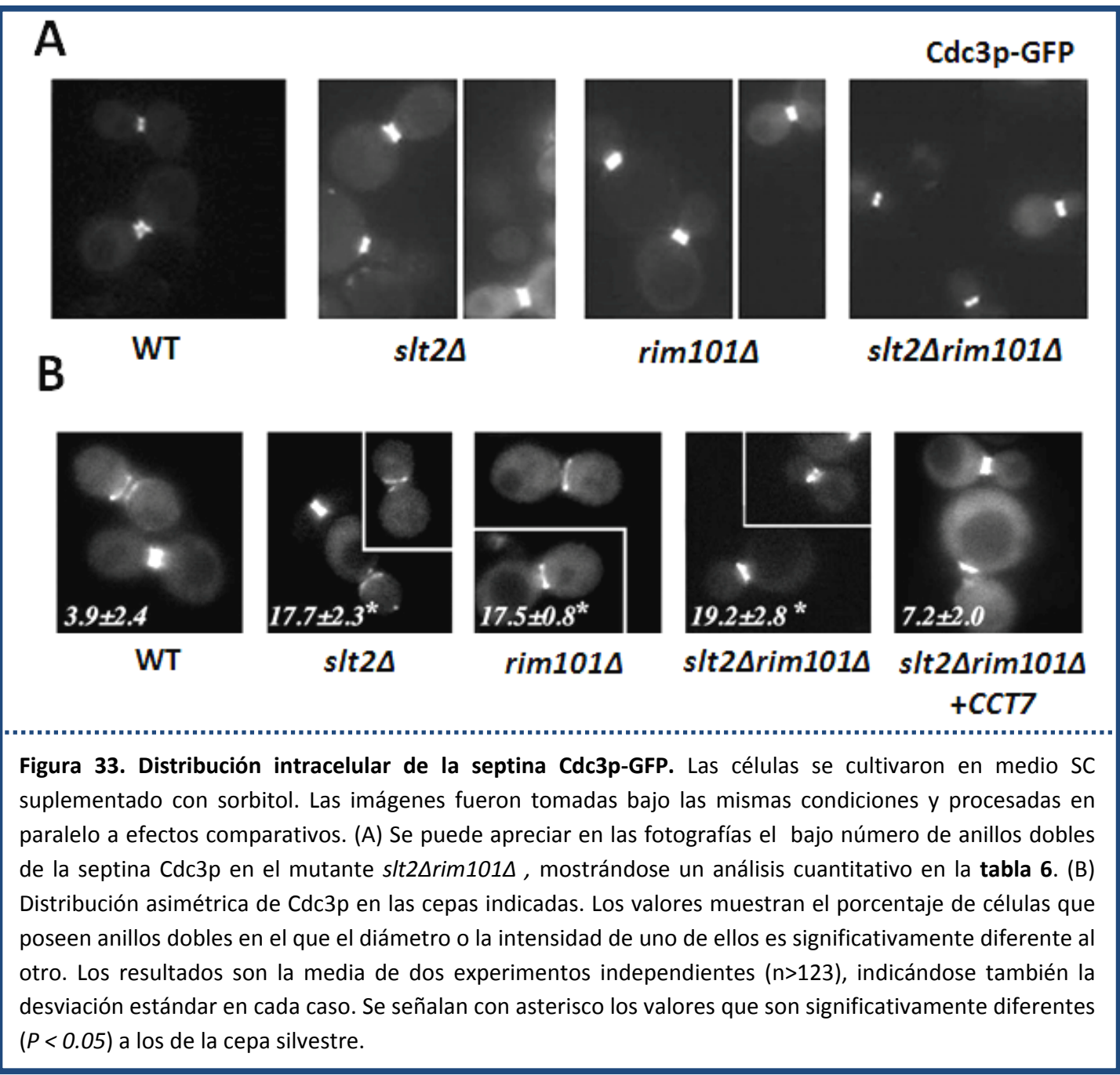

\begin{tabular}{|c|c|c|c|c|}
\hline \multirow[b]{2}{*}{ CEPAS } & \multicolumn{2}{|c|}{ Bni4p-YFP } & \multicolumn{2}{|c|}{ Cdc3p-GFP } \\
\hline & Sorbitol & Glucosamina & Sorbitol & Glucosamina \\
\hline WT & $44.0 \pm 6.4 \%(89)$ & $56.5 \pm 7.7 \%(75)$ & $52.8 \pm 8.9 \%(78)$ & $46.2 \pm 3.8 \%(78)$ \\
\hline slt2A & $29.5 \pm 1.1 \%(132) *$ & SD & $50.0 \pm 3.1 \%(95)$ & SD \\
\hline $\operatorname{rim101\Delta }$ & $60.6 \pm 2.8 \%(112)$ & SD & $41.9 \pm 12.7 \%(120)$ & SD \\
\hline slt2Arim1014 & $27.1 \pm 7.4 \%(193) *$ & $27.3 \pm 2.3 \%(55)^{*}$ & $28.4 \pm 5.3 \%(191) *$ & $15.2 \pm 4.2 \%(46)$ * \\
\hline 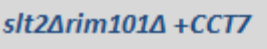 & SD & SD & $45.5 \pm 0.05 \%(101) \#$ & SD \\
\hline
\end{tabular}

Tabla 10. Localización de Bni4p-YFP y Cdc3p-GFP en las cepas señaladas. Los valores indican el porcentaje de anillos dobles observados en referencia al número total de células que muestran fluorescencia en el cuello. Los resultados son la media de tres experimentos independientes y se muestran las desviaciones estándar correspondientes. Las cifras que se encuentran entre paréntesis son el número de células contadas. El medio de cultivo empleado fue principalmente el SC sorbitol, aunque también se utilizó en determinados casos el SC con glucosamina. Se indican con un asterisco los valores que son significativamente $(P<0.05)$ menores con respecto a la estirpe silvestre, y con el símbolo almohadilla el incremento significativo $(P<0.05)$ del número de anillos dobles de la septina Cdc3p originado por la sobreexpresión de CCT7. SD=sin determinar. 


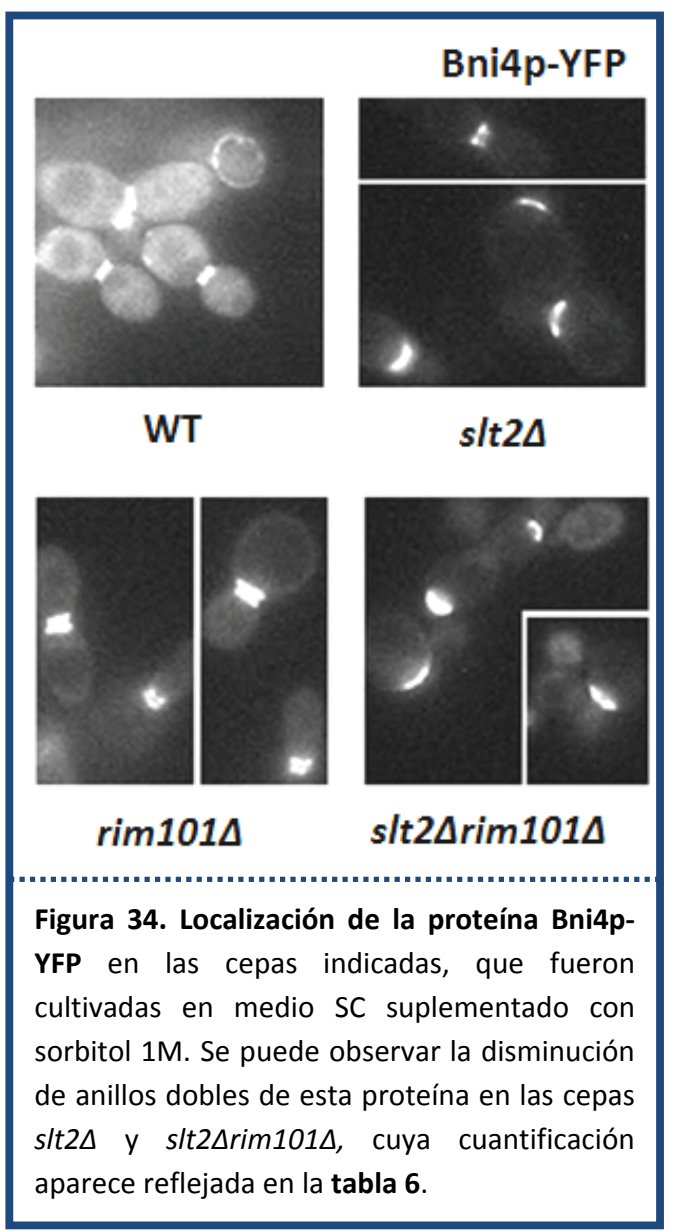

A partir de esta relación, no resultó sorprendente encontrar que Bni4p-YFP se acumulase de manera asimétrica en el lado de la célula madre en los mutantes s/t2 $\Delta$ y

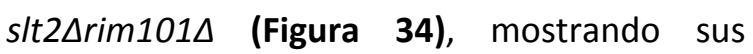
cultivos un número significativamente menor $(P<0.05)$ de anillos dobles en comparación con los cultivos de la cepa silvestre o del mutante rim101ه (Tabla 10). Asimismo cabe destacar que la señal presentada por esta proteína era considerablemente más ancha en los mutantes slt2 $\Delta$ (Figura 34 y Tabla 9). Esta localización aberrante que mostraba Bni4p-YFP parece estar debida a la ausencia de la MAP quinasa Slt2p, ya que los mutantes simples sit2 $\Delta$ presentaban estos mismos defectos independientemente del medio de cultivo y la estabilización osmótica del mismo (Datos no mostrados). Además, teniendo en cuenta el papel que desempeña Bni4p como proteína intermediaria entre las septinas y Chs4p, esta deslocalización explicaría también la acumulación reducida de Chs $3 p / C h s 4 p$ en la zona del cuello del mutante doble, que posee los defectos sumatorios ocasionados por las mutaciones s/t2 $2 \mathrm{y}$ rim $101 \Delta$.

Anteriormente habíamos descrito la recuperación del crecimiento del mutante doble que ocasionaban la adición de glucosamina al medio de cultivo y la sobreexpresión de los genes GFA1 y CCT7. Por ello quisimos estudiar los efectos que pudieran tener sobre el ensamblaje de las septinas. Ni la adición de glucosamina al medio (Tabla 10) ni la sobreexpresión de GFA1 (Datos no mostrados) aumentaron de forma significativa el número de dobles anillos de Bni4p-YFP o Cdc3p-GFP observados en el mutante doble, y por lo tanto, no parecían tener ningún tipo de efecto sobre el ensamblaje de la maquinaria de septación. Sin embargo, la sobreexpresión de CCT7 sí incrementó significativamente $(P<$ 0.05) el porcentaje de anillos dobles de septinas que se observaban en el mutante doble (Tabla 10), además de disminuir la acumulación asimétrica de Cdc3p-GFP (Figura 33B). 
Estos resultados confirman la hipótesis inicial de que la supresión llevada a cabo por GFA1 y CCT7 es debida a mecanismos independientes, aliviando CCT7 específicamente los defectos en el ensamblaje de la maquinaria del cuello.

\section{CARACTERIZACIÓN DE LOS SUPRESORES RESTANTES}

Una vez caracterizados en detalle los supresores antes descritos, nos planteamos continuar con la caracterización, al menos preliminar, del segundo grupo de plásmidos que fueron aislados en la búsqueda de supresores y no desencadenaban un aumento en la producción de quitina (Tabla 7, páginas 84 y 85)). Uno de ellos resultó incluir un retrotransposón (inserto \#6), y por ello no continuamos con su estudio. El inserto \#5 contenía tan sólo la fase de lectura abierta del gen $M S C 3$, y la recuperación del crecimiento

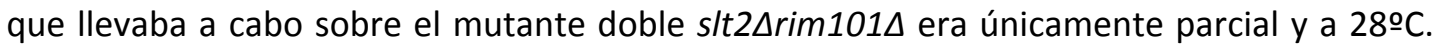
Esto nos sugirió que quizás pudiera ser debido a que el promotor de dicho gen se encontrara truncado en el plásmido de estudio, ya que dicho plásmido tan sólo poseía aproximadamente 80 pares de bases previas al codón de inicio. Por ello amplificamos mediante PCR alrededor de 1000 pb aguas arriba del codón de inicio de MSC3, y lo clonamos, junto con el resto del gen rescatado del inserto \#5, en un plásmido multicopia pRS426. Cuando lo transformamos en el mutante doble, comprobamos que no se podía reproducir la complementación observada anteriormente, eliminando por lo tanto dicho plásmido también del estudio. En el caso del inserto \#4, se vio que tan sólo conseguimos suprimir el fenotipo de letalidad sintética del mutante doble cuando subclonamos simultáneamente dos de los genes que se encontraban en dicho plásmido, RNA1 y $R N H 1$, sin poder concluir que alguno de los genes pudiera llevar a cabo tal efecto de forma independiente. No es posible en base a lo conocido sobre estos genes predecir el porqué de su capacidad supresora.

Respecto a PCL1, indicar que hemos sido capaces de identificarlo dos veces como

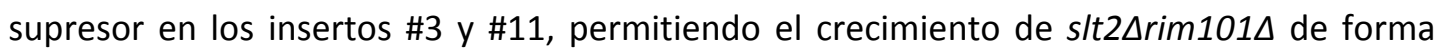
parcial a $28 \circ \mathrm{C}$ y $35 \circ \mathrm{C}$ (Figura 18). Anteriormente ya se había relacionado a PCL1 con SLT2 (Madden et al., 1997), afirmándose que la sobreexpresión de PCL1 complementaba la termosensibilidad presentada por el mutante s/t2 $\Delta$, aunque en nuestro caso no fuimos capaces de observar esta supresión. 


\section{Resultados}

Otros de los genes identificados fueron HRD1 y GEP3, presentes en los insertos \#12 y \#9 respectivamente, que posibilitaban el crecimiento del mutante doble a $28 \circ \mathrm{C}$ y $32 \circ \mathrm{C}$ tan sólo de manera parcial, y cuya relación con los fenotipos observados no puede predecirse.

SPH1, supresor contenido en el inserto \#8, revertía el fenotipo sintético letal del mutante doble de manera sutil. Su homóloga Spa2p posee un papel como proteína de andamiaje a componentes del módulo MAP quinasa de la ruta PKC como Mkk1p, Mkk2p y la propia SIt2p, siendo necesaria para la correcta localización de SIt2p en la zona del cuello (Van Drogen 2002). Por ello nos planteamos que la sobreexpresión de Spa2p en el mutante

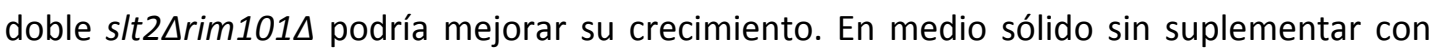
sorbitol, no hemos observado una mejora significativa del crecimiento del mutante doble al sobreexpresar SPA2 (Datos no mostrados).

La caracterización de estos supresores queda por lo tanto relegada a futuros estudios, puesto que la información obtenida hasta la fecha no nos ha proporcionado resultados de gran relevancia (Ver el apartado 2.2 de la Discusión).

\subsection{Supresión de slt2 $\Delta$ mediada por KSS1}

En el inserto \#13 fuimos capaces de identificar como supresor el gen KSS1, que codifica una proteína MAP quinasa involucrada en las rutas de transducción de señales que controlan la respuesta frente a feromonas y el crecimiento filamentoso (Breitkreutz \& Tyers, 2002), teniendo un papel más importante en esta última cascada. La sobreexpresión de KSS1 sobre el mutante s/t2Arim101A ejercida por el plásmido multicopia pRS424-KSS1, originaba un crecimiento parcial del mismo tanto a $28^{\circ} \mathrm{C}$ como a $32^{\circ} \mathrm{C}$, y de manera residual a 35ㄷ (Figura 18). SLT2 y KSS1 presentan una alta homología en sus secuencias nucleotídicas, alrededor del 56\%, y Kss1p es la proteína MAP quinasa de las dos rutas en las que participa, al igual que SIt2p lo es en la ruta PKC. Por lo tanto quisimos examinar si Kss1p podía reemplazar a SIt2p cuando ésta se encontraba ausente. Para ello transformamos el mutante simple s/t2A con el plásmido multicopia pRS424-KSS1 y comparamos el crecimiento que mostraba dicho transformante con la cepa control al crecer en presencia de cafeína o frente a altas temperaturas, estímulos frente a los que s/t2 $\Delta$ muestra sensibilidad. Se puede comprobar que la sobreexpresión de KSS1 sobre el mutante s/t2 $\Delta$ era 


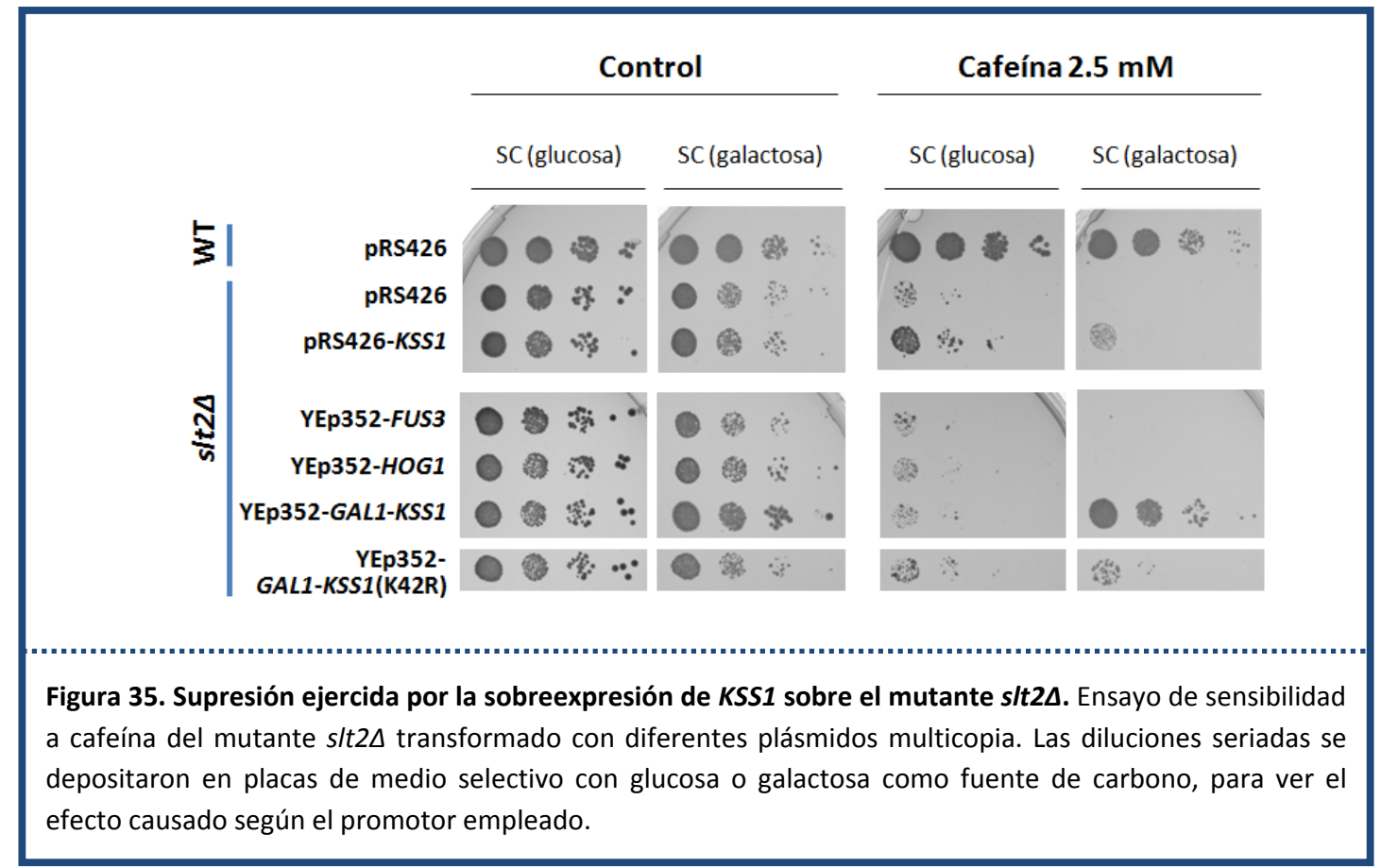

capaz de rescatar tan sólo parcialmente la sensibilidad frente a cafeína (Figura 35), sin ejercer una mejora cuando se incubaban las placas a $37^{\circ} \mathrm{C}$ (Datos no mostrados).

Además cabe destacar que esta supresión frente a cafeína era dependiente de dosis génica, ya que al sobreexpresar KSS1 bajo el control del promotor GAL1, que incrementa notablemente la expresión del gen respecto al plásmido usado previamente, el crecimiento en las placas con cafeína observado era notablemente superior. De igual manera, cuando empleamos un plásmido en el que KSS1 se encontraba clonado con su sitio catalítico mutado (YEp352-GAL1-KSS1-K42R), la resistencia frente a cafeína no se rescataba, confirmando que es imprescindible para la supresión que esta quinasa mantenga su actividad catalítica activa (Figura $\mathbf{3 5}$ ).

Puesto que existen otras proteínas MAP quinasa que intervienen en otras rutas de transducción de señales de S. cerevisiae (Chen \& Thorner, 2007), como son HOG1 (que participa en la respuesta frente al estrés causado por la alta osmolaridad) y FUS3 (implicada en la ruta de respuesta frente a feromonas), realizamos el mismo ensayo mediante el uso de los plásmidos multicopia YEp352-HOG1 y YEp352-FUS3. Se verificó que ninguno de los dos podía rescatar la sensibilidad que muestra $s / t 2 \Delta$ frente a temperaturas elevadas (Datos no mostrados) o cafeína (Figura 35). 


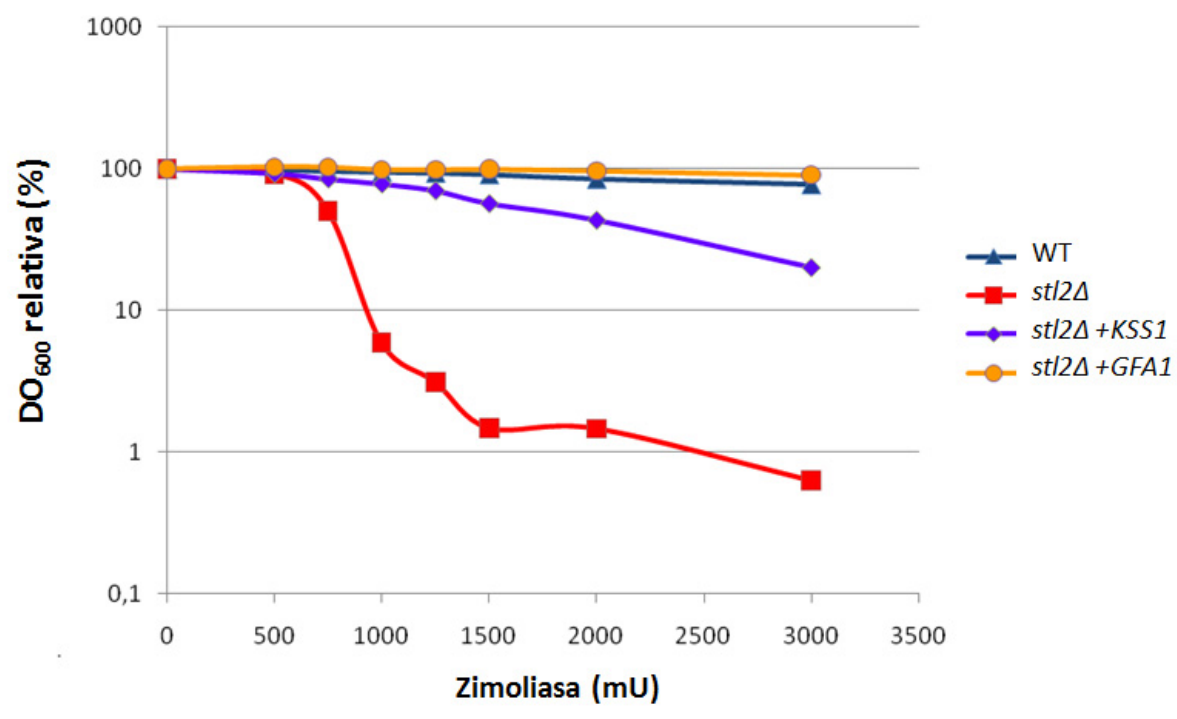

Figura 36. Ensayo de sensibilidad a zimoliasa de las cepas indicadas. Crecimiento de las cepas indicadas en medio SC suplementado con diferentes concentraciones de zimoliasa. La incubación se realizó a 28두 durante 16 horas. Los datos se expresan en escala logarítmica como el porcentaje de crecimiento relativo al crecimiento observado en ausencia de zimoliasa.

Uno de los fenotipos más característicos que presenta el mutante s/t2 $\Delta$ es la hipersensibilidad frente a zimoliasa, por lo que quisimos analizar si KSS1 era capaz de suprimirla. Cuando KSS1 se sobreexpresaba en ausencia de SLT2, apreciamos una recuperación parcial de la viabilidad respecto al comportamiento del mutante simple (Figura 36). Esta supresión sólo era mejorada por GFA1, que restauraba completamente la resistencia del mutante s/t2 $\Delta$ hasta niveles silvestres (Figura 36). Como bien es sabido, existen múltiples interacciones entre diferentes rutas de transducción de señales, lo que llevó a plantearnos la posibilidad de que KSS1 pudiera estar activando parcialmente al factor de transcripción RLM1 en ausencia de SLT2 y por tanto suprimiendo su falta. Para determinarlo, realizamos un ensayo de cuantificación de la actividad $\beta$-galactosidasa. Empleamos para ello un plásmido que contiene el promotor de MLP1, una diana transcripcional de la ruta PKC, acoplado a la fase de lectura abierta de lacZ, el gen que codifica la enzima $\beta$-galactosidasa, lo cual permite medir la activación transcripcional de la ruta de una forma cuantitativa (Garcia et al., 2009). Transformamos el mutante s/t2 $\Delta$ con el plásmido Yep352-MLP1-lacZ, y examinamos el efecto provocado por la sobreexpresión de KSS1 en respuesta a estímulos que activan esta ruta, como son la adición de calcoflúor (Figura 37) o zimoliasa (Datos no mostrados). Los resultados nos indicaban que la 
sobreexpresión de KSS1 no era capaz de incrementar en absoluto los niveles de actividad mostrados por el mutante slt2 $2 \Delta$ en presencia de estos compuestos, por lo que podemos afirmar que la supresión desempeñada por KSS1 en ausencia de SLT2 era totalmente independiente de la actividad transcripcional ejercida por RLM1.

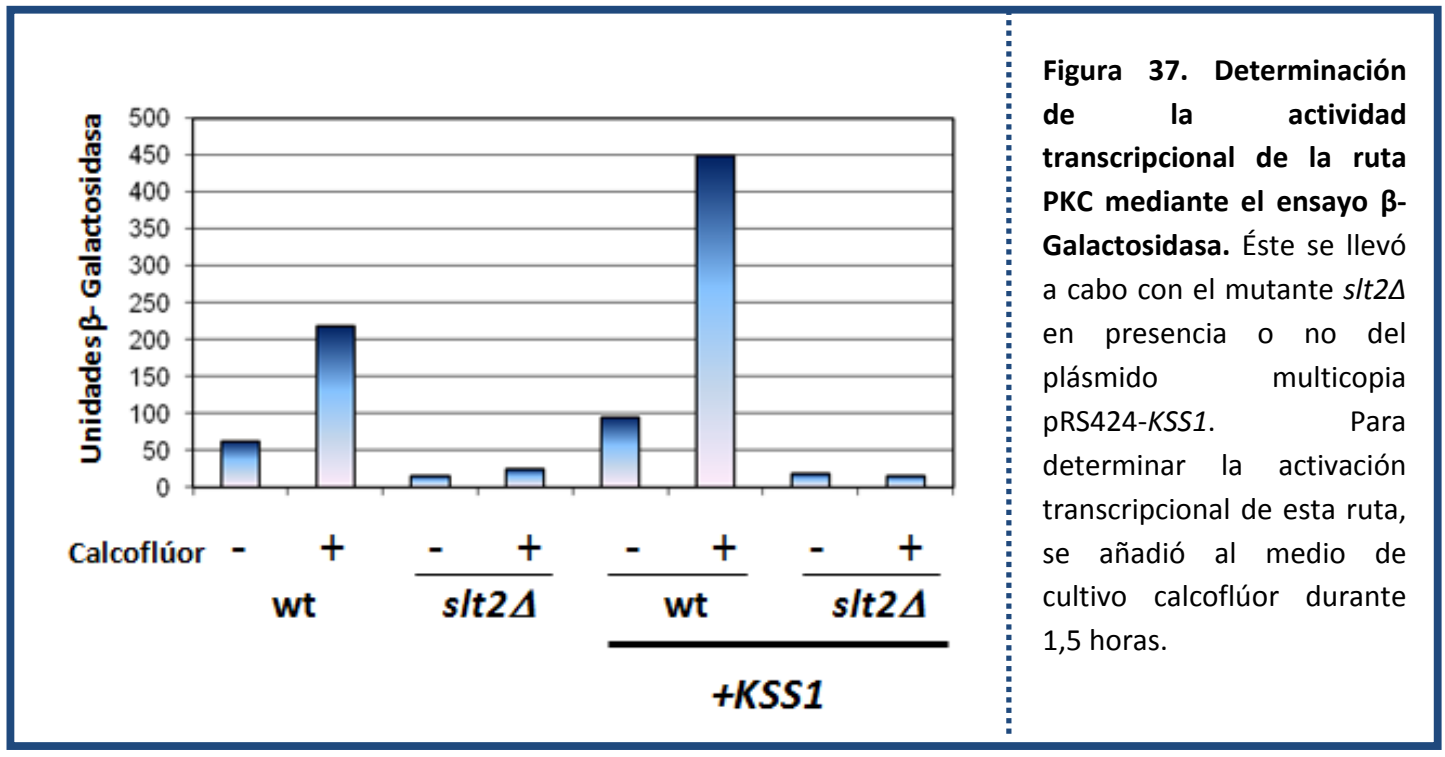

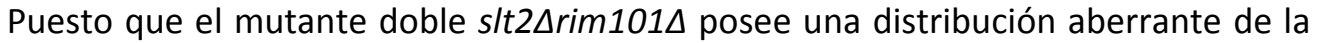
proteína Bni4p-YFP, sobreexpresamos KSS1 para determinar la ubicación de Bni4p, pudiendo comprobar que se recuperaba la localización observada en la cepa silvestre, aumentando notablemente el número de dobles anillos que presentaba este mutante (Figura 38). Además de estos datos, podemos añadir que el papel ejercido por KSS1 es totalmente independiente de la síntesis de quitina, puesto que al ser sobreexpresada en el mutante doble slt2 $\Delta$ rim $101 \Delta$ la señal del calcoflúor no se incrementaba, y tampoco

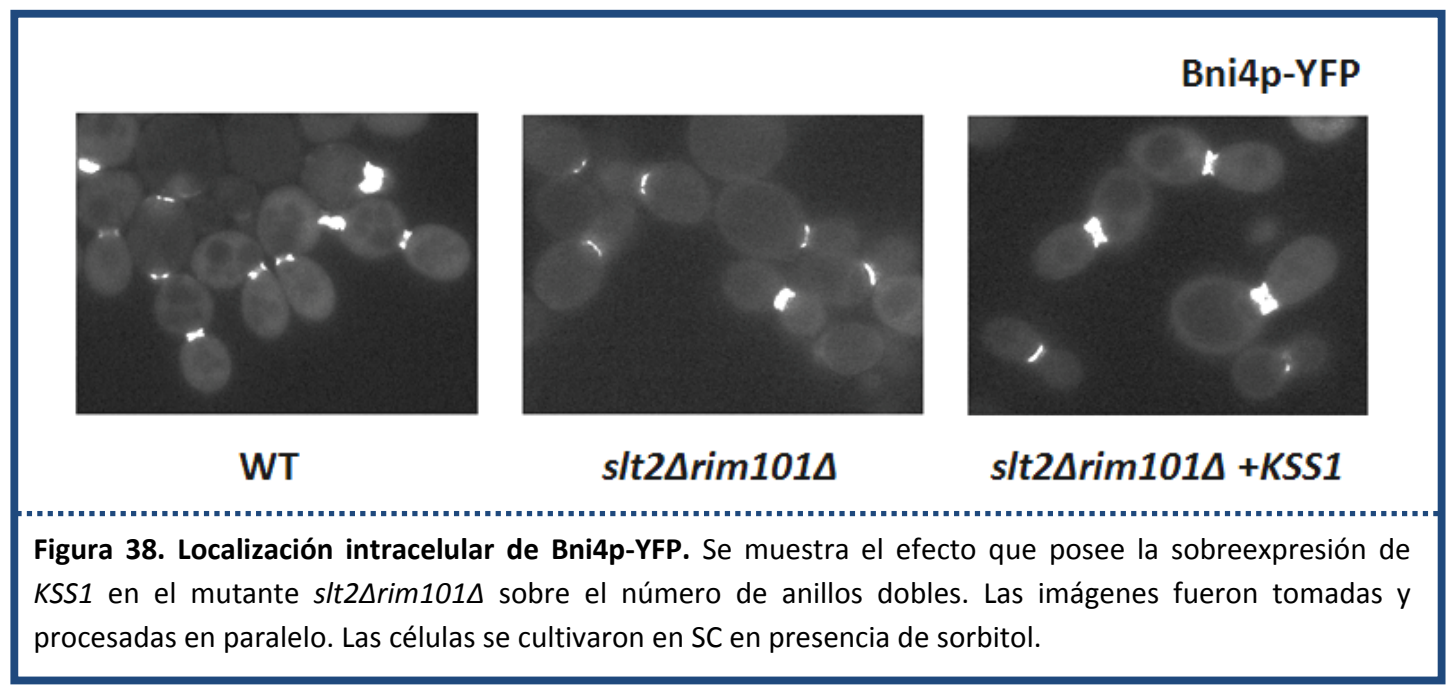




\section{Resultados}

observábamos un aumento en la cantidad de quitina presentada (Datos no mostrados). Esto nos confirma que la supresión que estaba llevando a cabo se encuentra más relacionada con la estabilización de la maquinaria de septación, tal y como ocurre con la chaperonina CCT7. En este escenario la hipótesis más probable es la acción sustitutiva que ejerce KSS1 sobre la maquinaria del cuello (Ver discusión).

\section{UN APORTE TÉCNICO: DEGRADACIÓN PROTEOLÍTICA

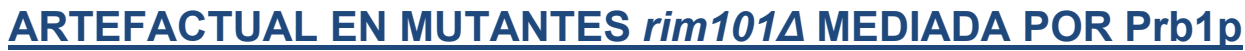

Los extractos proteicos necesarios para realizar experimentos de Western blot se obtienen en nuestro laboratorio utilizando una mezcla de inhibidores de proteasas que contiene aprotinina, leupeptina y pepstatina A (cada una de ellas a una concentración de 2 $\mu \mathrm{g} / \mathrm{ml})$, EDTA $5 \mathrm{mM}$, EGTA $5 \mathrm{mM}$ y PMSF $1 \mathrm{mM}$. Estos extractos se obtienen típicamente a partir de células recogidas y congeladas a $-80^{\circ} \mathrm{C}$. En estas condiciones observamos que, independientemente del medio utilizado para el crecimiento de las cepas, la cantidad de Chs4p-3xHA disminuía de forma considerable en el mutante rim101ム (Figura 39A). Este resultado fue inicialmente mal interpretado y nos llevó a especular con una degradación
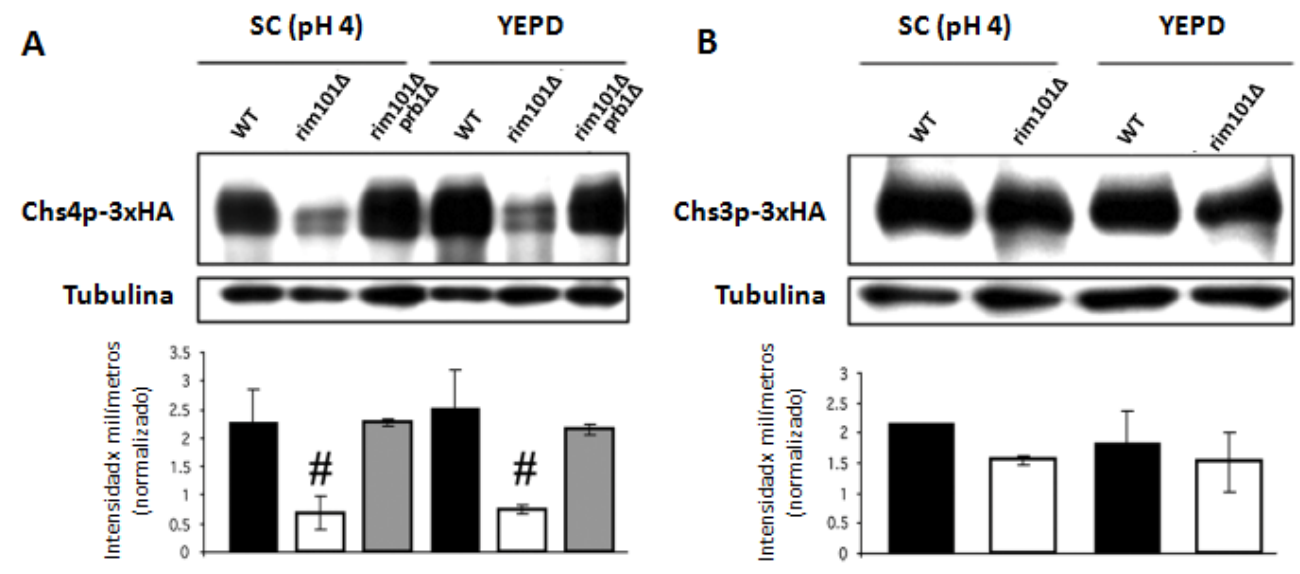

Figura 39. Análisis de los niveles de Chs4p-3xHA y Chs3p-3xHA. Las estirpes indicadas se transformaron con los plásmidos pRS315-CHS4-3xHA (A) y pRS315-CHS3-3xHA (B) y fueron cultivadas en los medios señalados. Los extractos se prepararon empleando PMSF $1 \mathrm{mM}$ en el tampón de lisis. Los gráficos representan la cuantificación, mediante análisis densitométrico, de los niveles de Chs4p-3xHA o Chs3p-3xHA normalizados respecto a la tubulina. Los valores indicados son la media de tres experimentos independientes y se señalan con (\#) los valores estadísticamente significativos $(P<0.01)$. 
específica de la proteína Chs4p en el mutante rim101ム (Figura 29). Sin embargo la cepa

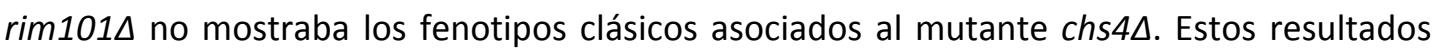
llevaron a plantearnos una posible degradación artefactual de Chs4p, sobre todo a raíz del incremento en la expresión de muchos genes en este mutante. Éste es el caso de la proteasa B (codificada por el gen PRB1), cuya expresión se incrementa en el mutante rim101ム en torno a 3 veces respecto a la cepa silvestre (Lamb \& Mitchell, 2003).

Para estudiar si la disminución en los niveles de Chs4p-3xHA en el mutante rim101ム podría ser debido a una degradación proteolítica artefactual ocasionada por Prb1p, revisamos el protocolo de obtención de los extractos proteicos. Por ello procesamos directamente las células una vez recogidas, evitando así la congelación de las mismas a -80 드, y empleamos mayores cantidades de PMSF permitiendo así que éste se encontrara en exceso, ya que el PMSF es un inhibidor de serín proteasas y Prb1p ha sido descrita como una serín proteasa similar a la subtilisina (Moehle et al., 1987). En estas condiciones de trabajo conseguimos abolir mayoritariamente la degradación de Chs4p-3xHA en el mutante simple rim101ム (Figura 30A). Además podemos asociar directamente la degradación

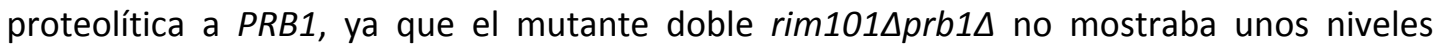
reducidos de Chs4-3xHA (Figura 39A), recuperándose los niveles que presentaba la cepa silvestre. Este efecto de degradación proteolítica llevado a cabo por PRB1 tiene distinta repercusión sobre diferentes proteínas, ya que ni la estabilidad de la tubulina ni la de Chs3p (Figura 39B) se veía afectada en el mutante rim101ム en las condiciones ensayadas originalmente.

Para comprobar que tan sólo existía un problema de degradación artefactual de Chs4p-3xHA sin tener una repercusión in vivo, construimos el mutante triple

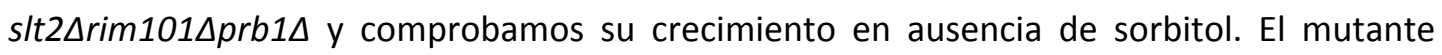
triple tenía los mismos problemas de viabilidad que el mutante doble (Figura 40A). De igual manera, determinamos si el mutante triple slt2 $\Delta$ rim $101 \Delta p r b 1 \Delta$ presentaba un aumento en

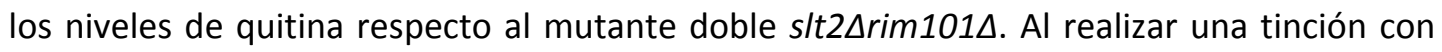
calcoflúor, observamos que el mutante triple poseía un nivel de fluorescencia semejante al observado en el mutante doble (Datos no mostrados). Asimismo pudimos comprobar que la

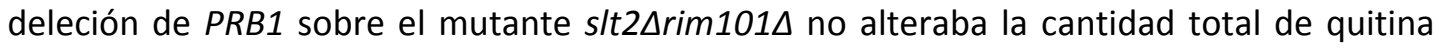
(Figura 40B). A la vista de los resultados obtenidos se puede afirmar que el efecto causado 


\section{Resultados}

por el aumento de la expresión de PRB1 se limitaba a una degradación proteolítica artefactual sin efecto fisiológico aparente. Hemos observado también que la degradación de Chs $4 p$ se produce en otras condiciones fisiológicas en las que se incrementan los niveles de Prb1p (Datos no mostrados). Aunque el efecto descrito aquí afecta a Chs4p, existe una alta probabilidad de que en el mutante rim101ડ se produzca la degradación artefactual de otras proteínas, lo que sería también extensible a todas las condiciones fisiológicas en las que se incrementan los niveles de Prb1p. Estas evidencias deben ser tenidas en cuenta al analizar el conjunto de las proteínas mediante Western blot.

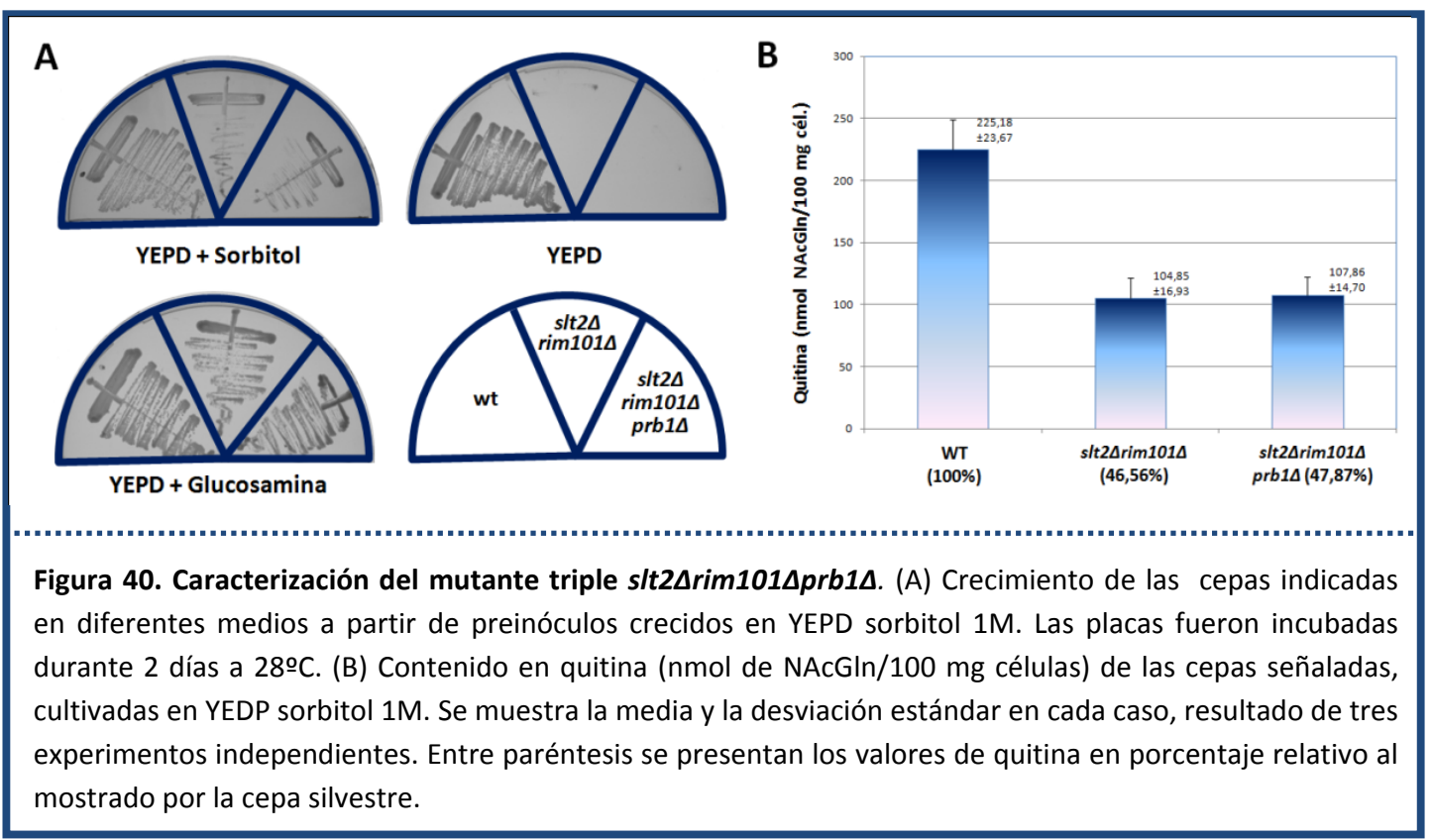




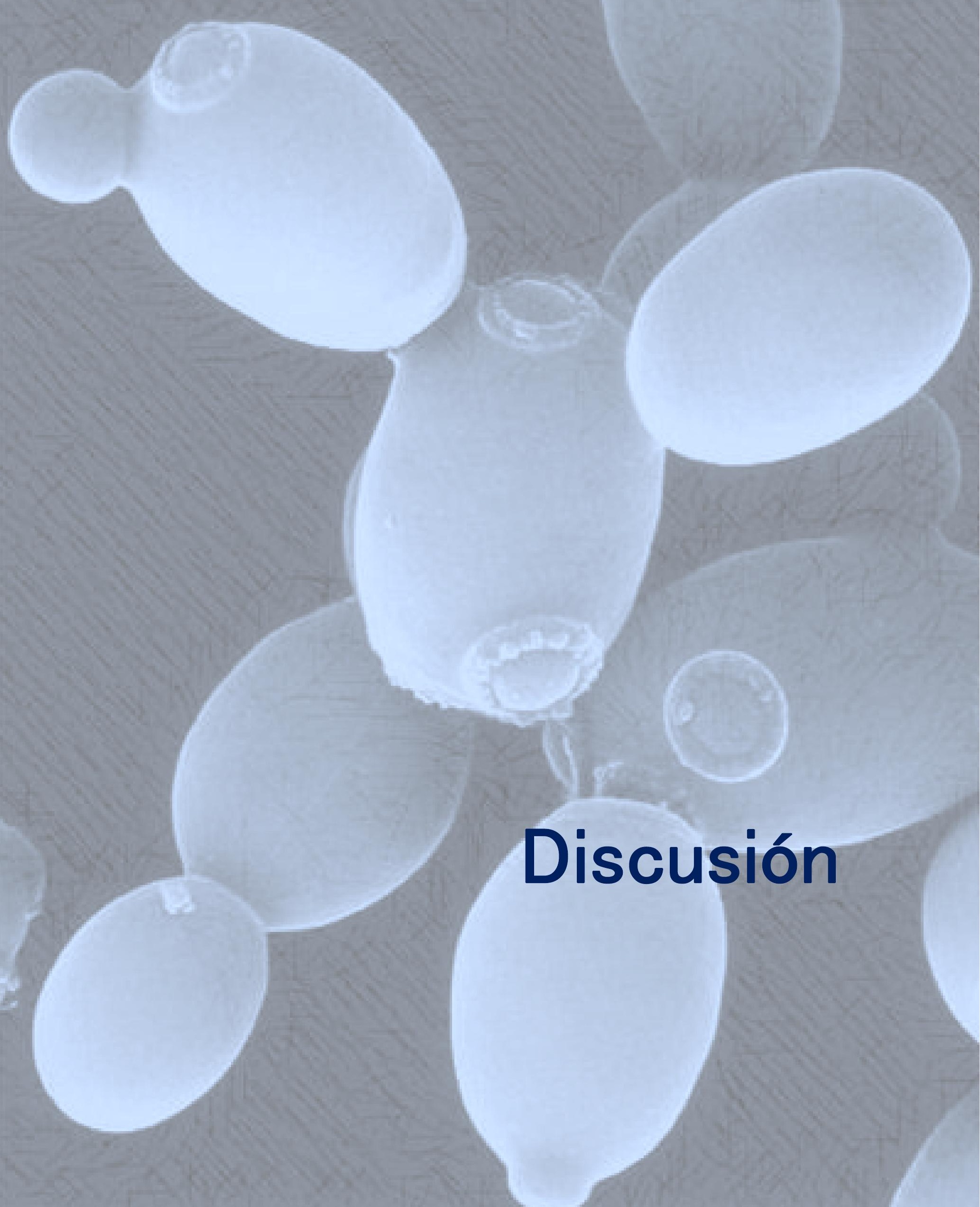



La pared celular es una estructura de gran importancia para la fisiología fúngica, ya que su ensamblaje está directamente asociado con el mantenimiento de la integridad celular, produciéndose la muerte celular cuando se inhibe la síntesis de algunos de sus componentes principales. Por todo ello la pared celular constituye una atractiva diana en el desarrollo de nuevos antifúngicos de toxicidad selectiva. El conocimiento de los mecanismos que regulan su síntesis es por tanto clave a la hora de entender los procesos morfogenéticos de la célula y su capacidad de adaptación frente a cambios medioambientales.

S. cerevisiae responde al daño ejercido sobre la PC principalmente a través de la ruta de integridad celular (ruta PKC o CWI), desencadenando un proceso conocido como respuesta compensatoria, en el cual se induce la expresión de un conjunto de genes a través del factor de transcripción RIm1p (Levin, 2005). La participación de esta ruta en la construcción de la pared está bien documentada, y durante mucho tiempo se ha considerado que era la única implicada en este proceso. Sin embargo, el trabajo reciente de diferentes grupos apuntan a una estrecha relación molecular de esta ruta de señalización con otras muchas, entre ellas la ruta HOG (Garcia-Rodriguez et al., 2005; Bermejo et al., 2008). Por lo tanto no es sorprendente encontrar en ensayos masivos múltiples mutantes que muestren defectos asociados a la PC.

\section{LA RUTA RIM101 POSEE UN PAPEL EN LA CONSTRUCCIÓN DE LA} PARED CELULAR

\subsection{Ynl294p/Rim21p es un miembro de la ruta RIM101 y participa en el ensamblaje de la pared celular}

En uno de los ensayos sistemáticos en los que participó nuestro grupo, se caracterizó una parte de los mutantes nulos de $S$. cerevisiae generados en el proyecto EUROFAN I. En este ensayo se demostró que el mutante yn/294D muestra resistencia parcial frente al calcoflúor (Figura 8A), a pesar de presentar unos niveles normales de actividad QSIII (de Groot et al., 2001). Estos fenotipos se habían observado anteriormente sólo en mutantes de la ruta HOG (Garcia-Rodriguez et al., 2000). A partir de este trabajo se 
ha podido confirmar el papel de la ruta HOG en el mantenimiento de la arquitectura de la pared celular, explorado a nivel molecular muchos años después (Bermejo et al., 2008).

Durante el transcurso de este proyecto se ha demostrado que la proteína Ynl294p forma parte de la ruta RIM101, pasando a denominarse Rim21p (Barwell et al., 2005). Hasta la fecha se había descrito que esta ruta estaba involucrada en la respuesta frente a la alcalinización del medio de crecimiento, el programa meiótico, la esporulación y el crecimiento invasivo, además de tener un papel en la resistencia frente a altas concentraciones de sodio y litio, o bajas temperaturas (Penalva et al., 2008). Nuestros resultados han confirmado la participación de $\operatorname{Rim} 21$ p en algunas de estas respuestas, aunque también hemos observado que este mutante presenta problemas durante la conjugación (Datos no mostrados). Los datos más destacados de esta caracterización apuntan a que el mutante rim $21 \Delta$ presenta una sensibilidad moderada frente a compuestos que afectan a la pared celular como el SDS, la cafeína o la zimoliasa (Figuras 9 y 17). Por ello, los resultados sugerían que la proteína Rim21p podría estar involucrada también en la construcción de la pared, a pesar de no haberse descrito anteriormente una participación de la ruta RIM101 en este proceso.

Las rutas PKC y RIM101 no parecen presentar elementos en común. A pesar de ello son varios los datos que podrían vincularlas. Recientemente se ha confirmado el papel que posee la ruta PKC en respuesta a $\mathrm{pH}$ alcalino, produciéndose su activación a través del sensor Wsc1p, y originando la expresión de varios genes relacionados con la pared celular (Serrano et al., 2006). Además, al describirse que Rim21p era un sensor de membrana (Barwell et al., 2005), resultaba tentador postular que Rim21p pudiera actuar como un sensor adicional de la ruta PKC. Este hecho estaría de acuerdo con la falta de fosforilación de SIt2 $p$ en el mutante rim21 (Figura 11) y con la similitud de fenotipos presentada por los

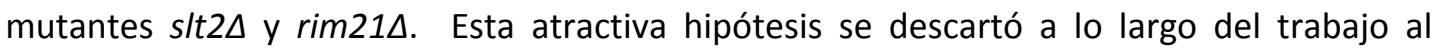

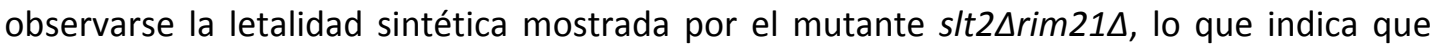
Rim21p y Slt2p actúan en paralelo y no de forma jerarquizada en una misma ruta. Posteriormente se ha demostrado que la letalidad sintética del mutante slt2 $2 \Delta$ se extiende a todos los mutantes rim $\Delta$, gracias tanto a la información extraída de los ensayos masivos (Tong et al., 2004) y la base de datos DRYGIN (del laboratorio del Dr. Charles Boone), como a resultados obtenidos en nuestro laboratorio (Figura 13). De igual manera, todos los 
mutantes rim $\Delta$ parecen presentar similares fenotipos asociados a defectos en la pared celular. En este contexto no es de extrañar que la viabilidad del mutante doble s/t2 $\Delta$ rim $21 \Delta$ se rescate en presencia de sorbitol, un estabilizador osmótico que previene la lisis celular ocasionada por defectos en la pared. De todo ello debemos concluir que las rutas RIM101 y PKC se encuentran actuando de manera conjunta en la construcción de la pared celular.

Una vez establecida la implicación de la ruta de respuesta a pH alcalino en el ensamblaje de la pared celular, nos formulamos la siguiente cuestión. ¿Cuál es el papel exacto que la ruta RIM101 desempeña en este proceso? La respuesta no es sencilla, ya que aún se desconoce bastante acerca de la naturaleza de la pared celular y las interacciones existentes entre los componentes que la forman. Además, las alteraciones que muestran los mutantes simples rim $\Delta$ en relación con la estructura de la pared celular son bastante leves y no afectan a su crecimiento. Sin embargo, la viabilidad celular se ve seriamente comprometida cuando los defectos de los mutantes rim $\Delta$ se combinan con la ausencia de Slt2p, lo que puede ayudar a explicar este papel. Tradicionalmente se ha venido relacionando a SIt2 $p$ con la respuesta transcripcional mediada por la ruta PKC, que es ejercida a través del factor de transcripción Rlm1p. Sorprendentemente los mutantes

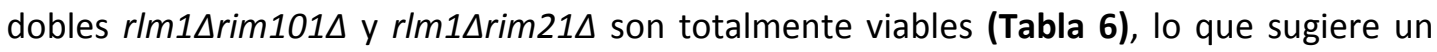
papel especifico de SIt2p en los efectos descritos, mayoritariamente independiente de la respuesta transcripcional de la ruta PKC.

Esta hipótesis se ve reforzada gracias a la información obtenida a través de los patrones de interacción de letalidad sintética que presentan distintos mutantes de la ruta PKC (Figura 41). Aunque $b c k 1 \Delta$ y slt2 $\Delta$ comparten una interacción de letalidad sintética con un amplio conjunto de mutantes, ambos muestran interacciones que son exclusivas de cada uno de ellos. Lo mismo ocurre con el mutante carente del factor de transcripción $R L M 1$. Hay que tener en cuenta que probablemente existan gran cantidad de interacciones genéticas desconocidas hasta la fecha. Sin embargo estos datos nos proporcionan una información relevante que sugiere que cada miembro de la ruta PKC, además de formar parte de ella, puede actuar de manera específica en múltiples procesos celulares. A la vista de la información recogida en la Figura 41, resulta interesante comprobar que la gran mayoría de las interacciones mostradas por s/t2A no son compartidas con $\operatorname{rlm} 1 \Delta$, confirmando de nuevo que Slt2p debe poseer funciones que serían mayoritariamente 


\section{Discusión}

independientes de la respuesta transcripcional de la ruta PKC. Entre ellas se encontraría el papel que ejerce sobre la PC en combinación con la ruta RIM101.

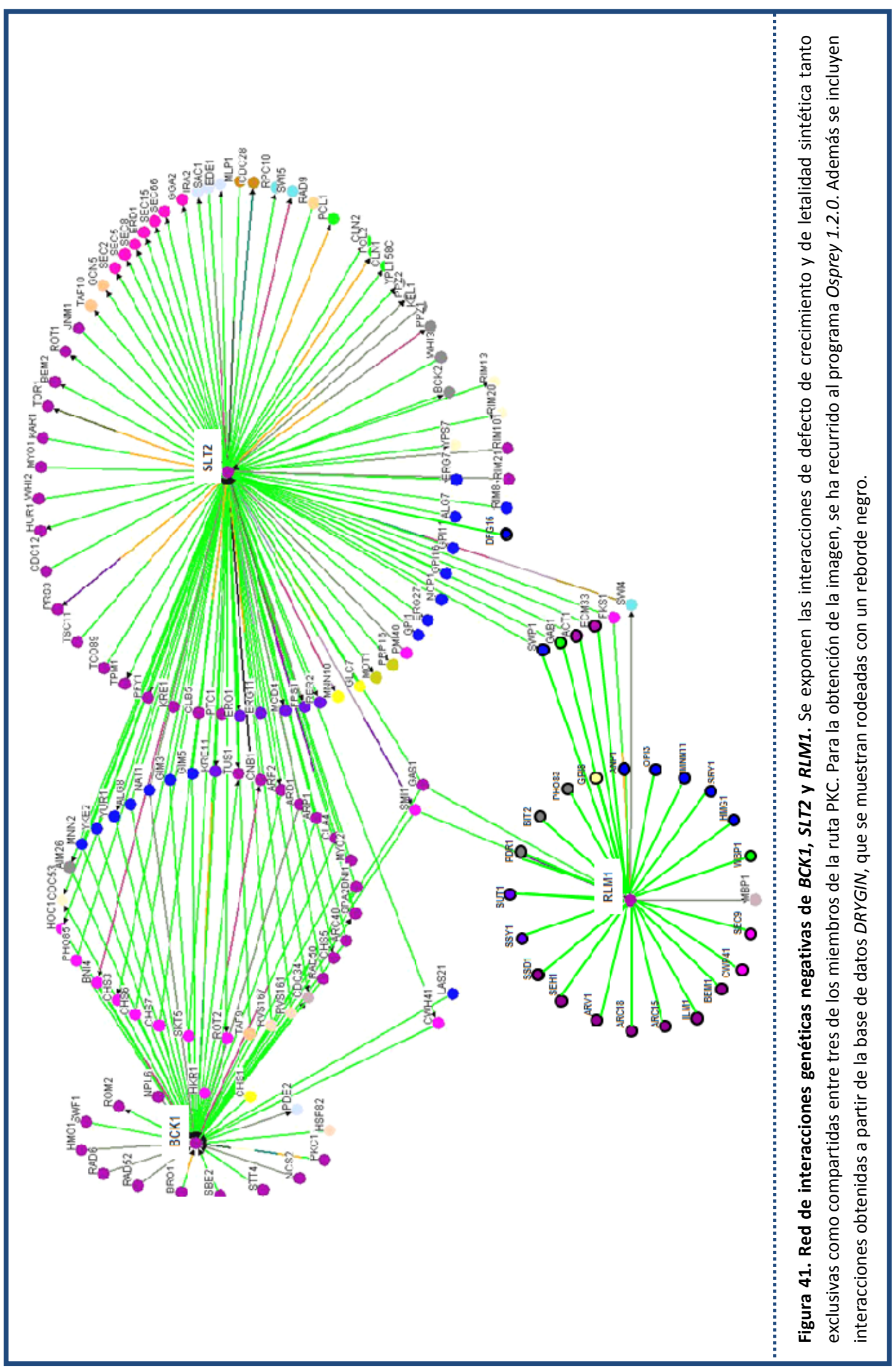




\subsection{Rim101p colabora en la construcción de la pared gracias a su papel como regulador transcripcional.}

Existen aún muchas incógnitas acerca de la respuesta transcripcional llevada a cabo por la ruta RIM101. A diferencia de la regulación transcripcional en A. nidulans, donde PacC es capaz de actuar como activador y represor transcripcional, en S. cerevisiae Rim101p actúa fundamentalmente como represor (Penalva et al., 2008). Cuando RIM101 se deleciona, existe un amplio número de genes que se sobreexpresan y otros cuya expresión disminuye (Lamb \& Mitchell, 2003). Entre ellos encontramos un grupo de genes implicados en conjugación (AGA2, BAR1 y MFA1). Este hecho podría relacionarse con resultados aún preliminares de nuestro laboratorio en el que se observan los defectos de algunos mutantes rims en conjugación. De igual manera, la expresión de los represores transcripcionales NRG1 y SMP1 está bajo el control de Rim101p, aumentando su expresión

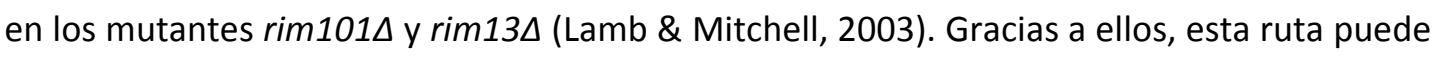
regular indirectamente diferentes procesos celulares entre los que se encuentran el crecimiento invasivo, la homeostasis iónica, la respuesta frente al $\mathrm{pH}$ alcalino, etc. $\mathrm{Si}$ tenemos en cuenta que Smp1p es un factor de transcripción de la familia MADS-box, al igual que RIm1p, podría suponerse que un incremento en los niveles de este represor pudiera ser responsable de los defectos observados en los mutantes rim $\Delta$. Sin embargo, la deleción de SMP1 suprime sólo marginalmente los defectos de pared mostrados por el mutante rim21 (Figura 14), sugiriendo que no habría un único gen regulado por Rim101p que pudiera ser responsable directo de los defectos observados en los mutantes de la ruta RIM101. Es interesante destacar que varios de los genes que se encuentran desregulados en el mutante rim101ム están directamente implicados en la construcción o remodelación de la pared celular. Es el caso de YJR061W, SHC1, CTS1, CWP1, AGA2, KTR5, UTR2...(Lamb \& Mitchell, 2003), aunque como se verá más adelante la desregulación de otros genes puede llevar a efectos indirectos y a priori no esperados en el ensamblaje de la pared. El efecto aditivo de las alteraciones de varias de estas actividades enzimáticas podría ser un posible causante de las anomalías descritas en los mutantes rim $\Delta$. Sin embargo, ninguno de estos genes posee un papel estructural relevante en la pared, por lo que no es de extrañar que los defectos que observamos sean sumamente sutiles, incluso a nivel de microscopía electrónica de transmisión (Figura 16). 
Todos estos datos suponen la primera evidencia experimental que relaciona la ruta RIM101 con el ensamblaje de la pared celular de S. cerevisiae, y la caracterización biológica

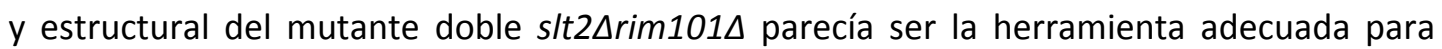
esclarecer el papel que ejercen tanto Rim101p como Slt2p en la integridad celular de esta levadura.

\section{LA PRESENCIA CONJUNTA DE SIt2p $Y$ Rim101p RESULTA IMPRESCINDIBLE EN LA INTEGRIDAD DEL CUELLO}

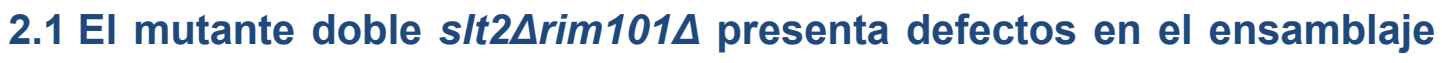 del anillo de quitina}

La caracterización del mutante s/t2 $\Delta$ rim $101 \Delta$, cuya letalidad es suprimida por sorbitol, muestra que éste contiene unos niveles de quitina significativamente disminuidos, lo que se traduce en la formación de un anillo de quitina defectuoso (Figuras 19 y 21). Este efecto se debe claramente a la ausencia conjunta de las dos proteínas, ya que los mutantes

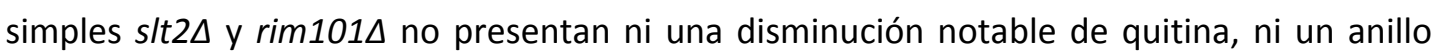
alterado. Sin embargo, estos defectos no son suficientes para explicar por qué el mutante doble no es viable, ya que la cepa chs $3 \Delta$, que carece completamente de anillo de quitina, crece perfectamente en todas las condiciones probadas. En caso de existir un septo defectuoso, éste podría verse afectado por el incremento en la expresión de CTS1 originado por la deleción de RIM101 (Lamb \& Mitchell, 2003). Nuestros resultados confirman esta posibilidad, ya que la sobreexpresión de la quitinasa empeora el crecimiento del mutante slt2 $\Delta$ (Figura 26), aunque no tiene ninguna repercusión sobre chs3 $\Delta$ (Dato no mostrado).

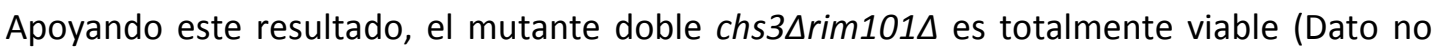
mostrado), lo cual sugiere que la ausencia de SLT2 es el principal motivo de la letalidad

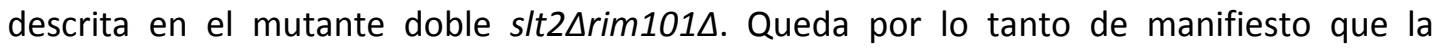
inviabilidad de dicho mutante está causada por la combinación de varios factores: un defecto en la síntesis de quitina, un incremento en la expresión de la quitinasa y la propia ausencia de SIt2p, cuyos efectos analizaremos en profundidad más adelante. Estos resultados explican directamente los resultados observados en los que tanto la deleción de 
CTS1 como el incremento en la síntesis de quitina alivian la letalidad sintética del mutante doble (Figuras 22 y 25).

La microscopía electrónica pone además de manifiesto que el mutante doble

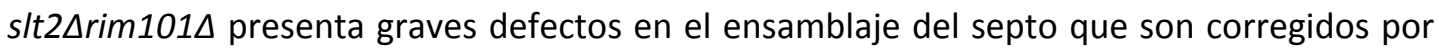
el incremento en la síntesis de quitina (Ver más adelante), pero no por la deleción del gen CTS1 (Figura 28). Estos resultados indican claramente que el mutante doble posee defectos intrínsecos en el ensamblaje del septo que se ven agravados por la acción desregulada de la quitinasa sobre él. Ésta constituye la primera evidencia directa del papel de Slt2p en el ensamblaje del septo.

\subsection{SIt2p y Rim101p contribuyen de manera independiente en el correcto ensamblaje de la maquinaria de septación}

A partir de esta primera evidencia, la cuestión siguiente era determinar el hipotético papel de SIt2p y de la ruta RIM101 en el ensamblaje del septo. Así hemos

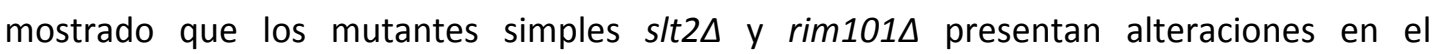
ensamblaje del anillo de septinas que podrían explicar alguno de los problemas que poseen estas cepas, como la sensibilidad frente a quitinasa o la resistencia a calcoflúor, respectivamente. En concreto, la septina Cdc3p se distribuye de manera asimétrica en los dos mutantes, indicando un ensamblaje alterado del anillo de septinas (Figura 33B). Las causas moleculares que ocasionan esta asimetría parecen ser diferentes en ambos casos, provocando por ello distintos efectos biológicos. Así, la distribución de Bni4p, que se ancla directamente al anillo de septinas (DeMarini et al., 1997), se ve seriamente afectada tan sólo en los mutantes slt2 $\Delta$, mostrando una distribución más ancha y asimétrica (Figura 34). El efecto de las mutaciones rims parece más sutil y podría estar relacionado con la disminución en los niveles de Rsb1p (Ikeda et al., 2008), una proteína necesaria para el mantenimiento de la asimetría lipídica en la membrana (Ver más adelante). En todo caso, la acumulación de estos defectos individuales podría explicar los fallos presentados por el

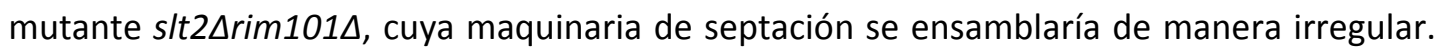
Esto, unido a la disminución en los niveles de quitina de esta cepa, provocaría finalmente la lisis celular. Esta hipótesis se ve reforzada al comprobar que los mutantes dobles s/t2 $\Delta b n i 4 \Delta$ y s/t2 $\Delta$ chs $3 \Delta$ no son viables (Lesage et al., 2005), ya que acumulan por un lado los defectos 


\section{Discusión}

debidos a slt2 $2 \Delta$ y presentan además un anillo de quitina defectuoso (bni4 $\Delta$ ) (Larson et al.,

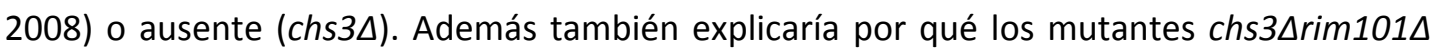

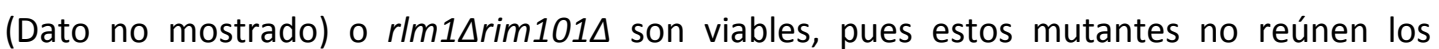
defectos asociados a las septinas debidos a la deleción de SLT2. Los problemas que hemos descrito en las septinas de nuestros mutantes no son tan aparentes como los que presentan otros mutantes como cla4t (Schmidt et al., 2003), lo que puede explicar en nuestro caso la distribución normal de la proteína Myo1p en ausencia de SIt2p y/o Rim101p (Figura 32) y la síntesis aparentemente silvestre del septo primario en los mutantes individuales (Figura 28), síntesis que no ocurre normalmente en los mutantes cla4 $\Delta$ o en otros con defectos graves en el ensamblaje de septinas.

Los defectos observados en el ensamblaje de septinas se ven también reforzados por la supresión de la letalidad sintética promovida por la sobreexpresión de CCT7 en el mutante doble. CCT7 es un miembro del complejo de chaperoninas citosólicas denominado CCT que posee múltiples funciones celulares, entre las cuales se encuentra el adecuado plegamiento de la actina y la tubulina (Kabir et al., 2005). Recientemente se ha descrito que este complejo interacciona con el anillo de septinas, siendo necesario para su correcto ensamblaje (Dekker et al., 2008). Nuestros datos confirman esta relación, ya que la

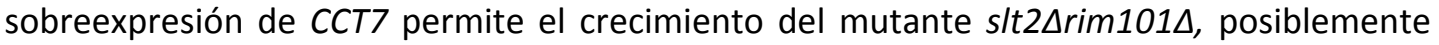
gracias a la mejora en el ensamblaje del anillo de septinas (Figura 33B). De acuerdo con este modelo, CCT7 carece de una función vinculada con la síntesis de quitina, por lo que el incremento en la tinción de calcoflúor al sobreexpresar CCT7 podría estar más relacionado con un ensamblaje alterado del septo que con un incremento real de la síntesis de quitina.

Aunque disponemos todavía de poca información acerca de las causas que originan la supresión mediada por varios de los genes aislados en nuestro escrutinio, alguno de ellos como SPH1 y KSS1 vuelven a poner de manifiesto la relación de Slt2p con la maquinaria del septo. En ausencia de SIt2p, la proteína Bni4p presenta una distribución asimétrica que era capaz de ser revertida al sobreexpresar KSS1 (Figura 38). Asimismo Slt2p interacciona genéticamente con Glc7p (Andrews \& Stark, 2000a), la subunidad catalítica de la fosfatasa PP1 que se asocia a Bni4p en el cuello (Larson et al., 2008). Por un lado, las alteraciones observadas en la localización de Bni4p podrían ser debidas a una función alterada de Glc7p en el mutante s/t2 $\Delta$. Por otro lado, Bni4p es una proteína que puede encontrarse 
fosforilada, aunque se desconoce el papel que pueda desempeñar esta fosforilación (Zou et al., 2009). Se ha descrito la existencia de la interacción genética entre SLT2 y BNI4 (Lesage et al., 2005), así como la interacción física entre Kss1p y Bni4p (Hruby et al., 2011) (Figura

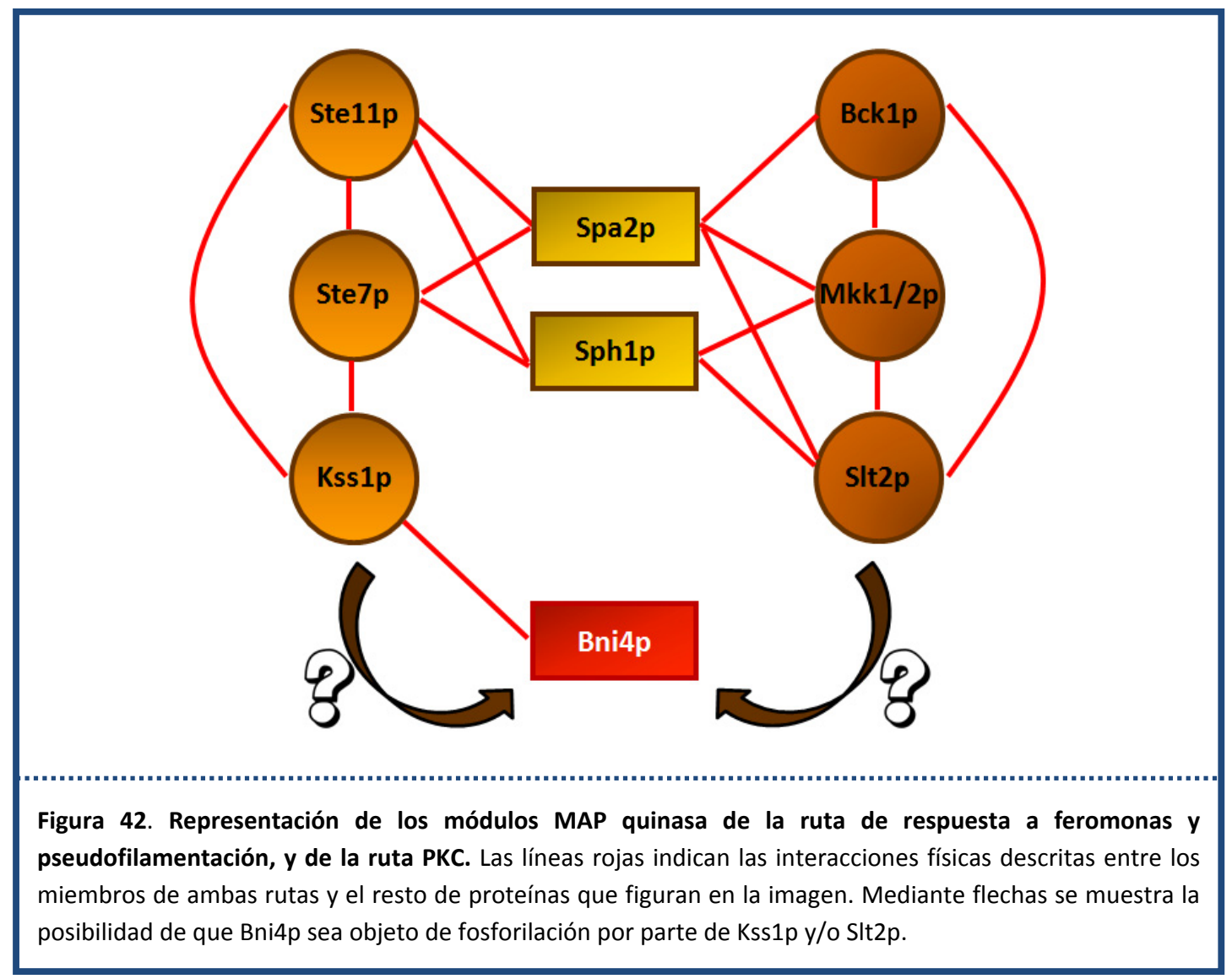

42). Aunque por el momento se desconoce si Slt2p y Bni4p interaccionan físicamente, no resulta descabellado pensar que Bni4p pudiera ser una diana potencial de SIt2p y/o Kss1p, debido a sus papeles como proteínas quinasas. Esta fosforilación podría repercutir en la localización y funcionalidad de Bni4p, tal y como ocurre con la fosforilación que lleva a cabo Pho85p sobre esta proteína (Zou et al., 2009). Además, Bni4p interacciona físicamente con varias proteínas del septo ayudándolas a establecer una correcta estructura del cuello. Por lo tanto, a pesar de que Bni4p no sea una proteína esencial, un fallo en su localización podría producir un defecto general en la distribución de varias proteínas en esta zona, entre ellas las septinas, lo cual implicaría consecuencias negativas para la viabilidad de la célula (Gladfelter et al., 2005; Zou et al., 2009).

Aún es complicado establecer el papel exacto de Slt2p en el correcto ensamblaje del septo, pero todo apunta a que posee alguna función en esta región, ya que además 


\section{Discusión}

Slt2p se localiza en el cuello durante parte del ciclo celular (van Drogen \& Peter, 2002). Spa2p actúa como proteína de andamiaje de Mkk1/2p (MAPKK de la ruta PKC) y Slt2p, siendo imprescindible para la correcta localización de ambas proteínas en los lugares de crecimiento polarizado (van Drogen \& Peter, 2002). Se ha descrito que las proteínas homólogas Spa2p y Sph1p interaccionan físicamente, además de con Mkk1/2p y Slt2p (Roemer et al., 1998), con Ste11p y Ste7p (Figura 42). Pudiera ser que en ausencia de Slt2p, Sph1p reclutara a Ste11p y Ste7p favoreciendo así el papel de Kss1p como estabilizador de la maquinaria de septación. Este efecto sería tan indirecto que podría explicar por qué la sobreexpresión de SPH1 da lugar tan sólo a una mejora sutil en el crecimiento del mutante doble slt2 $\operatorname{rim} 101 \Delta$, y la sobreexpresión de SPA2 no tiene efecto alguno (Resultado no mostrado). Podemos concluir por tanto que Slt2p interviene en la correcta organización del septo a pesar de que aún desconocemos los mecanismos moleculares que median esta función.

El hipotético papel del factor de transcripción Rim101p es de momento bastante más enigmático. Recientemente se ha descrito que el gen RSB1, cuya expresión disminuye en torno a cinco veces en el mutante rim101د (Lamb \& Mitchell, 2003), está implicado en el mantenimiento de la asimetría lipídica de las membranas (Ikeda et al., 2008). Esta asimetría es imprescindible en gran cantidad de funciones celulares y podría afectar a la asociación de múltiples proteínas a la membrana, especialmente a la de aquéllas que se anclan a través de dominios prenilados. Curiosamente Chs $4 p$ se encuentra prenilada y su distribución es anómala en el mutante rim1014, deslocalizándose hacia las yemas y ausentándose a lo largo de la membrana plasmática (Figura 29B). Esta localización se asemeja a la que presentan las cepas que carecen del dominio de prenilación de Chs $4 p$, lo que impide que esta proteína se asocie a la membrana de forma correcta (Reyes et al., 2007). En estas condiciones, el complejo QSIII activo no se anclaría correctamente al cuello, promoviéndose una síntesis deslocalizada de quitina, que es exactamente lo que sucede tanto en el mutante $r s b 1 \Delta$ (Figura 31A) como en el mutante rim101 $\Delta$. Además, el mutante doble $r s b 1 \Delta s / t 2 \Delta$, aunque viable, presenta un nivel significativo de lisis (Figura 31B), relacionando al menos parte de los problemas ocasionados por la ausencia de RIM101 con la desregulación de RSB1. Sin embargo es muy probable que la desregulación de RSB1 tenga efectos pleiotrópicos sobre otras muchas proteínas. 


\subsection{Papel homeostático del anillo de quitina en la integridad del cuello}

Además de lo indicado anteriormente, la función de Chs4p se vería afectada debido

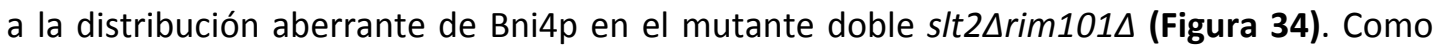
Bni4p es imprescindible para anclar el complejo QSIII al anillo de septinas (DeMarini et al., 1997), este mutante presenta una acumulación menor tanto de Chs $4 p$ como de Chs3p en el cuello (Figura 29A), lo que provoca una síntesis de quitina alterada. Además, la asociación de Chs4p a la membrana determina su propia estabilidad (Reyes et al., 2007), viéndose ésta comprometida en el mutante doble (Figura 30A), razón por la cual observamos una acumulación de Chs4p en la vacuola, donde es degradada (Figura 29A). Chs3p está implicada en la síntesis de quitina de las paredes laterales, así como en la síntesis del septo de remediación cuando la formación del septo primario se ve comprometida; sin embargo, su función más característica es la formación del anillo de quitina (Shaw et al., 1991; Cabib \& Schmidt, 2003). La función que desempeña este anillo no está del todo clara, puesto que los mutantes chs $3 \Delta$, que carecen de esta estructura, tan sólo muestran leves defectos morfológicos. A pesar de ello, la importancia que posee queda de manifiesto al observar el patrón de letalidad sintética que presentaba en ensayos masivos el mutante chs $3 \Delta$ con la colección de mutantes nulos de $S$. cerevisiae, resultando sintético letal o semiletal con más de 150 mutantes que carecen de genes implicados en una gran cantidad de procesos celulares (Lesage et al., 2005).

El anillo de quitina que se sintetiza en el mutante s/t2 $\Delta$ rim $101 \Delta$ se encuentra significativamente alterado, lo que en combinación con los otros defectos comentados ocasionaría la letalidad observada. La adición de glucosamina al medio o la sobreexpresión de GFA1 provocarían un incremento de la actividad QSIII presente en el cuello del mutante

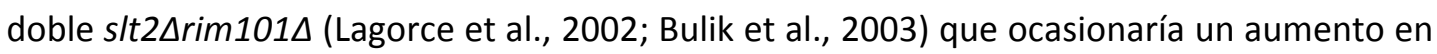
la cantidad de quitina sintetizada (Figura 19C). Esto garantiza la formación de un anillo de quitina aparentemente normal, que daría lugar a la recuperación de la arquitectura silvestre del septo (Figuras 21 y 28). Con todos estos datos queda claramente de manifiesto la importancia fisiológica que posee el anillo de quitina durante la citoquinesis y el efecto supresor de la letalidad causado por la glucosamina o la sobreexpresión de GFA1.

Se ha descrito anteriormente que este anillo y el anillo de septinas suponen mecanismos redundantes en el mantenimiento de la integridad del cuello celular (Figura 


\section{Discusión}

43). Debido a ello, apenas se pueden observar alteraciones en el cuello cuando existe un defecto menor en las septinas o en el anillo de quitina. Sin embargo cuando ocurre un fallo simultáneo en ambas estructuras, se produce una desorganización del aparato de septación y un ensanchamiento del cuello que conducen a la muerte celular (Schmidt et al., 2003). Estas observaciones explicarían la letalidad del mutante doble s/t2 $\Delta$ rim $101 \Delta$, y por qué los mutantes sencillos son perfectamente viables. También explica la aparición de dos grupos de supresores diferentes: unos, glucosamina o GFA1, capaces de corregir los defectos en el anillo de quitina y otros, CCT7 o KSS1, capaces de mejorar el ensamblaje del anillo de septinas $\sin$ modificar la síntesis de quitina (Figura 43).

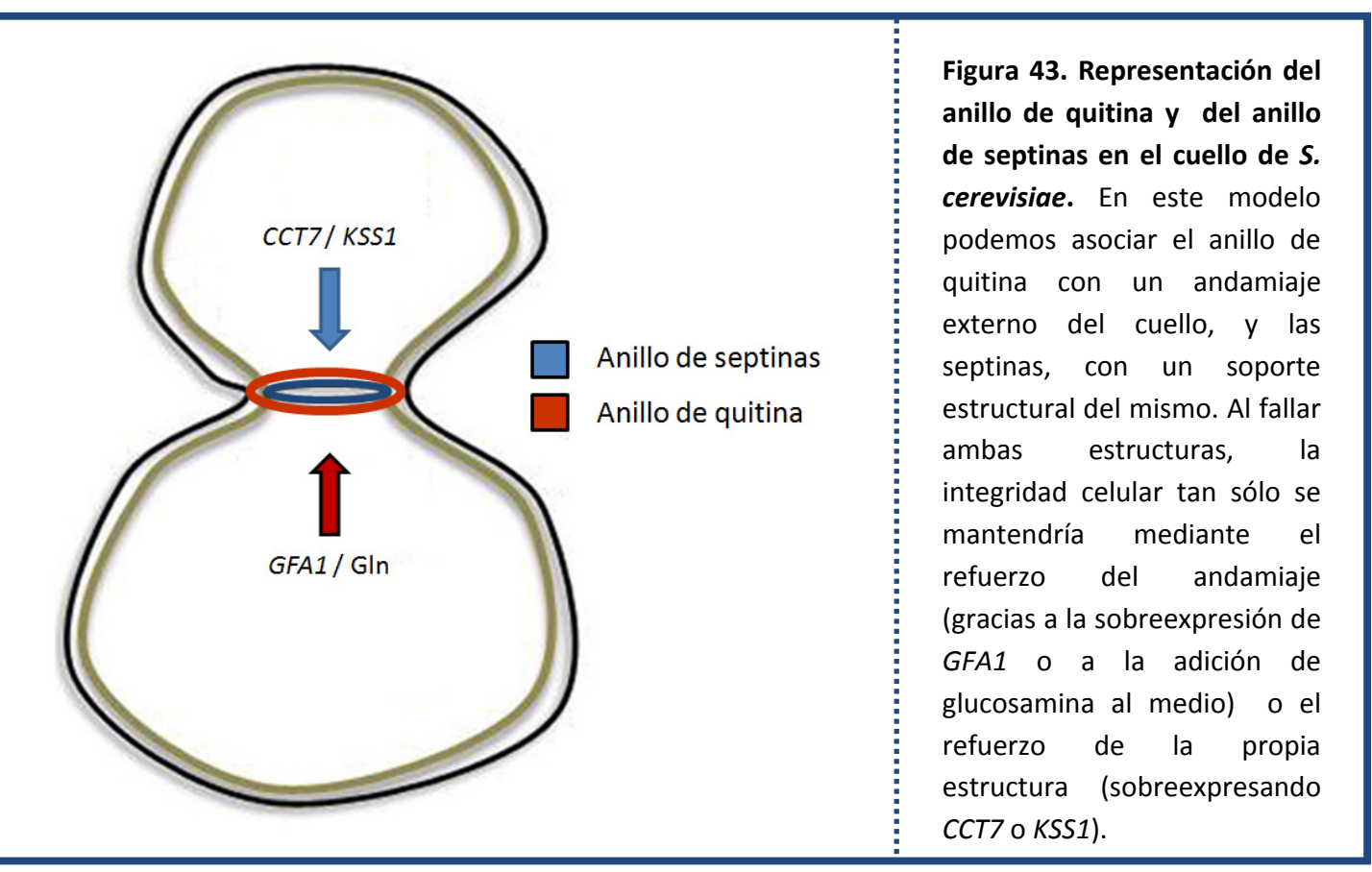




1.- La ruta RIM101 participa de forma directa en la construcción de la pared celular. Esta participación se realiza a través de una desregulación general de múltiples genes potencialmente implicados en el ensamblaje de la pared celular, y se llevaría a cabo en paralelo al papel ejercido por la ruta PKC.

2.- La falta de las rutas PKC y RIM101 origina la lisis celular, siendo esta letalidad sintética directamente dependiente de la MAP quinasa Slt2p y mayoritariamente independiente de la respuesta transcripcional mediada por la ruta PKC.

3.- La ausencia conjunta de SIt2p y de la ruta RIM101 produce la lisis celular a nivel del cuello debido a la acumulación de múltiples defectos como son la reducción de los niveles de quitina, la sobreexpresión de la actividad quitinasa y el incorrecto ensamblaje de la maquinaria del septo, que conduce a la síntesis de un anillo de quitina defectuoso.

4.- La letalidad sintética del mutante s/t2Arim $101 \Delta$ se suprime por un incremento en la síntesis de quitina, que puede ser causado por la sobreexpresión de GFA1 o por el crecimiento en medios suplementados con glucosamina

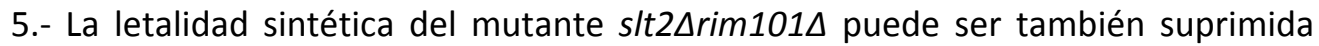
por una mejora en el ensamblaje de la maquinaria del septo debida a la sobreexpresión de CCT7 o KSS1, las cuales mimetizarían fisiológicamente el papel de Slt2p en el ensamblaje de esta maquinaria.

6.- El aumento en la expresión de la proteasa PRB1 ocasionado por la ausencia de Rim101p promueve una degradación proteolítica artefactual que afecta de forma diferente a diversas proteínas, lo que puede provocar conclusiones erróneas en todas aquellas condiciones en las que se produzca la sobreexpresión de PRB1. 



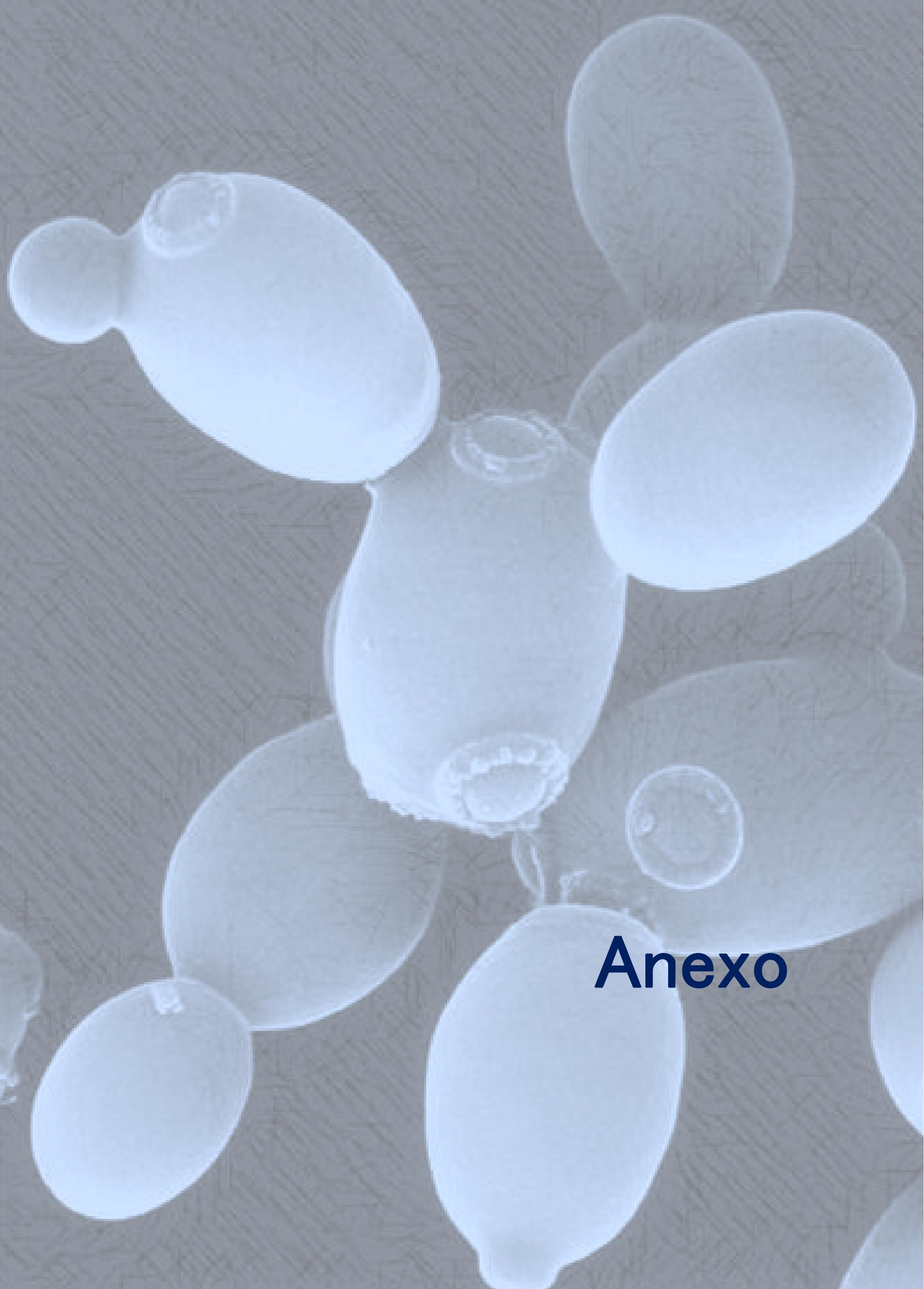



Tabla S-1. Oligonucleótidos más relevantes empleados en este trabajo.

\begin{tabular}{|c|c|c|}
\hline Nombre & Secuencia & Finalidad \\
\hline RIM8-pAG25-F & $\begin{array}{l}\text { ATGTCGTTACTGAGACTGTGGAACAAAGAATCAAGGG } \\
\text { CACCACGACATGGAGGCCCAGAAT }\end{array}$ & Deleción de $R / M 8$ \\
\hline RIM8-pAG25-R & $\begin{array}{l}\text { TAATAGTCATCACAAGGGGGAGGATCGCTTTCTAACTG } \\
\text { TTGTACACTGGATGGCGGCGTTA }\end{array}$ & Deleción de $R I M 8$ \\
\hline RIM8-F & CACGTTCTACTGTCTAGC & $\begin{array}{l}\text { Comprobación de la } \\
\text { deleción de } R I M 8\end{array}$ \\
\hline RIM8-R & AATAGCGTGAACGAGGTG & $\begin{array}{l}\text { Comprobación de la } \\
\text { deleción de } R I M 8\end{array}$ \\
\hline RIM9-pAG25-F & $\begin{array}{l}\text { GATTTATACGGTTGAGACAGATTCATTGAGGAAAAGA } \\
\text { GGAGACGACATGGAGGCCCAGAAT }\end{array}$ & Deleción de $R I M 9$ \\
\hline RIM9-pAG25-R & $\begin{array}{l}\text { AGCCGATTGGCAAACCGATGTAACGTGCAAAATGACA } \\
\text { CATGAACACTGGATGGCGGCGTTA }\end{array}$ & Deleción de RIM9 \\
\hline RIM9-F & GCAACGAATTACGCAGTG & $\begin{array}{l}\text { Comprobación de la } \\
\text { deleción de RIM9 }\end{array}$ \\
\hline RIM9-R & GCTCGCAGGTGTAAGTAC & $\begin{array}{l}\text { Comprobación de la } \\
\text { deleción de RIM9 }\end{array}$ \\
\hline RIM13-pAG25-F & $\begin{array}{l}\text { TACTCGACCATTTCAGTCGAAGACAAGAACCTTGTGGT } \\
\text { ATCACGACATGGAGGCCCAGAAT }\end{array}$ & Deleción de RIM13 \\
\hline RIM13-pAG25-R & $\begin{array}{l}\text { AGAATTGTAAAAAGGATGGATAGACAGTTCTTGAGAT } \\
\text { AAAGCACACTGGATGGCGGCGTTA }\end{array}$ & Deleción de RIM13 \\
\hline RIM13-F & CCATCAGTGAGCTTCCTA & $\begin{array}{l}\text { Comprobación de la } \\
\text { deleción de RIM13 }\end{array}$ \\
\hline RIM13-R & GCTCAAAAGACCTCAGCA & $\begin{array}{l}\text { Comprobación de la } \\
\text { deleción de RIM13 }\end{array}$ \\
\hline DFG16-pAG25-F & $\begin{array}{l}\text { TCACAAGCATTTTTTTGTTGCGGAACGTCTTTACGTGCA } \\
\text { AGATCGACATGGAGGCCCAGAAT }\end{array}$ & Deleción de DFG16 \\
\hline DFG16-pAG25-R & $\begin{array}{l}\text { AGGCAGCTGTACTTCTGCAGTTATGTCTTTTCGTCCACT } \\
\text { GGGACACTGGATGGCGGCGTTA }\end{array}$ & Deleción de DFG16 \\
\hline DFG16-F & GCCTATGTGCACAGATAA & $\begin{array}{l}\text { Comprobación de la } \\
\text { deleción de DFG16 }\end{array}$ \\
\hline DFG16-R & CCTTACAACATTCGCCTT & $\begin{array}{l}\text { Comprobación de la } \\
\text { deleción de DFG16 } \\
\end{array}$ \\
\hline RIM20-pAG25-F & $\begin{array}{l}\text { TACTATACCCTTGCAGAGAGAGTATTATTATCTATGGA } \\
\text { GATCCGACATGGAGGCCCAGAAT }\end{array}$ & Deleción de RIM20 \\
\hline RIM20-pAG25-R & $\begin{array}{l}\text { AGGATGACAAGCTCAAAATATACTTTATAGATGAATGA } \\
\text { GGACACACTGGATGGCGGCGTTA }\end{array}$ & Deleción de RIM20 \\
\hline RIM20-F & CCAACCATCTGAATCGGT & \begin{tabular}{|l} 
Comprobación de la \\
deleción de $R I M 20$
\end{tabular} \\
\hline RIM20-R & CCTGACATCAAAGGCGAT & $\begin{array}{l}\text { Comprobación de la } \\
\text { deleción de RIM20 }\end{array}$ \\
\hline RIM21-pAG25-F & $\begin{array}{l}\text { TTAGTAGCACATAAGGAGGAAGACACTCGAT } \\
\text { GAATAGTCGATCGACATGGAGGCCCAGAAT }\end{array}$ & Deleción de RIM21 \\
\hline RIM21-pAG25-R & $\begin{array}{l}\text { ATATAAATATGTAGGTTTGTTGTAATACTGTTTC } \\
\text { TGCTGTGTACACTGGATGGCGGCGTTA }\end{array}$ & Deleción de RIM21 \\
\hline
\end{tabular}


Anexo

\begin{tabular}{|c|c|c|}
\hline RIM21-5'-no cod & TAGAAGAGCAACCCACATCG & $\begin{array}{l}\text { Comprobación de la } \\
\text { deleción de } R / M 21\end{array}$ \\
\hline RIM21-3'-no cod & CATATGCATCTTGAGCATGC & $\begin{array}{l}\text { Comprobación de la } \\
\text { deleción de RIM21 }\end{array}$ \\
\hline RIM101-pAG25-F & $\begin{array}{l}\text { ATAAATACTGAAAACGGTAAAGTAGGTTTGTTTAAAT } \\
\text { TGACCGACATGGAGGCCCAGAAT }\end{array}$ & Deleción de RIM101 \\
\hline RIM101-pAG25-R & $\begin{array}{l}\text { AGCCGCAAAGAAACAACTAAGAATAAAATATCCGAC } \\
\text { AATCCAACACTGGATGGCGGCGTTA }\end{array}$ & Deleción de RIM101 \\
\hline RIM101-5' & TGACCCAAGCACGTTGGCAA & $\begin{array}{l}\text { Comprobación de la } \\
\text { deleción de RIM101 }\end{array}$ \\
\hline RIM101-sec2 & GATGCGGATAATGACGGT & $\begin{array}{l}\text { Comprobación de la } \\
\text { deleción de RIM101 }\end{array}$ \\
\hline PRB1-pAG25-F & $\begin{array}{l}\text { GCTTCATCGCCAATAAAAAAACAAACTAAACCTAATT } \\
\text { CTAACCGACATGGAGGCCCAGAAT }\end{array}$ & Deleción de PRB1 \\
\hline PRB1-pAG25-R & $\begin{array}{l}\text { ATAGTGAAGAGGGACTCCGACTTGTAACCTCGAGAC } \\
\text { GCCTAAACACTGGATGGCGGCGTTA }\end{array}$ & Deleción de PRB1 \\
\hline PRB1-F & AACACACCCGCGATAAAGA & $\begin{array}{l}\text { Comprobación de la } \\
\text { deleción de PRB1 }\end{array}$ \\
\hline PRB1-R & ATGTAGTAATACGTGGGACA & $\begin{array}{l}\text { Comprobación de la } \\
\text { deleción de } P R B 1\end{array}$ \\
\hline SPA2-pAG25-F & $\begin{array}{l}\text { ACGAGCCACCGAAACAGAATAAACAAAAGAAAAGAA } \\
\text { AGAGTACGACATGGAGGCCCAGAAT }\end{array}$ & Deleción de SPA2 \\
\hline SPA2-pAG25-R & $\begin{array}{l}\text { TTGTCTTTGTCTTCCTTTTCTTTCTCCTCTAGATACTACT } \\
\text { AAACACTGGATGGCGGCGTTA }\end{array}$ & Deleción de SPA2 \\
\hline SPA2-F & AGCTACGAGTGCTCTTGC & $\begin{array}{l}\text { Comprobación de la } \\
\text { deleción de SPA2 }\end{array}$ \\
\hline SPA2-R & CGGCGATAGCTTAAGCAT & $\begin{array}{l}\text { Comprobación de la } \\
\text { deleción de SPA2 }\end{array}$ \\
\hline RSB1-F & CGCTATCTCGCTCTCTAA & $\begin{array}{l}\text { Extracción del } \\
\text { casete de deleción } \\
\text { rsb1 } 1:: k a n M X 4\end{array}$ \\
\hline RSB1-R & СTCTATGGGAAACTCTGT & $\begin{array}{l}\text { Extracción del } \\
\text { casete de deleción } \\
r s b 1 \Delta:: k a n M X 4\end{array}$ \\
\hline RSB1-F-EXT & CCAGAGCATAGCACAATC & $\begin{array}{l}\text { Comprobación de la } \\
\text { deleción de } R S B 1\end{array}$ \\
\hline RSB1-INT & TCGCATTCTAATGTCGCC & $\begin{array}{l}\text { Comprobación de la } \\
\text { deleción de } R S B 1\end{array}$ \\
\hline GFA1-F & TTCTATCTCTCGTGTCACC & $\begin{array}{l}\text { Diseño de sonda } \\
\text { para Northern blot }\end{array}$ \\
\hline GFA1-R & ATGGCCCTTTCTTGCAGTA & $\begin{array}{l}\text { Diseño de sonda } \\
\text { para Northern blot }\end{array}$ \\
\hline ACT1-F & ATTGTCCGTGACATCAAGGA & $\begin{array}{l}\text { Diseño de sonda } \\
\text { para Northern blot }\end{array}$ \\
\hline ACT1-R & GGGCTCTGAATCTTTCGTTAC & \begin{tabular}{|l|} 
Diseño de sonda \\
para Northern blot
\end{tabular} \\
\hline
\end{tabular}




Alic, N., Higgins, V. J., Pichova, A., Breitenbach, M. \& Dawes, I. W. (2003). Lipid hydroperoxides activate the mitogen-activated protein kinase Mpk1p in Saccharomyces cerevisiae. J Biol Chem 278(43): 41849-41855.

Andrews, P. D. \& Stark, M. J. (2000a). Type 1 protein phosphatase is required for maintenance of cell wall integrity, morphogenesis and cell cycle progression in Saccharomyces cerevisiae. J Cell Sci 113 ( Pt 3): 507-520.

Andrews, P. D. \& Stark, M. J. (2000b). Dynamic, Rho1p-dependent localization of Pkc1p to sites of polarized growth. J Cell Sci 113 ( Pt 15): 2685-2693.

Babst, M., Katzmann, D. J., Estepa-Sabal, E. J., Meerloo, T. \& Emr, S. D. (2002). Escrt-III: an endosome-associated heterooligomeric protein complex required for mvb sorting. Dev Cell $3(2): 271-282$.

Baetz, K., Moffat, J., Haynes, J., Chang, M. \& Andrews, B. (2001). Transcriptional coregulation by the cell integrity mitogen-activated protein kinase SIt2 and the cell cycle regulator Swi4. Mol Cell Biol 21(19): 6515-6528.

Baladron, V., Ufano, S., Duenas, E., Martin-Cuadrado, A. B., del Rey, F. \& Vazquez de Aldana, C. R. (2002). Eng1p, an endo-1,3-beta-glucanase localized at the daughter side of the septum, is involved in cell separation in Saccharomyces cerevisiae. Eukaryot Cell 1(5): 774-786.

Bar, E. E., Ellicott, A. T. \& Stone, D. E. (2003). Gbetagamma recruits Rho1 to the site of polarized growth during mating in budding yeast. J Biol Chem 278(24): 21798-21804.

Bardwell, L. (2005). A walk-through of the yeast mating pheromone response pathway. Peptides 26(2): 339-350.

Bartnicki-Garcia, S. (1968). Cell wall chemistry, morphogenesis, and taxonomy of fungi. Annu Rev Microbiol 22: 87-108.

Barwell, K. J., Boysen, J. H., Xu, W. \& Mitchell, A. P. (2005). Relationship of DFG16 to the Rim101p pH response pathway in Saccharomyces cerevisiae and Candida albicans. Eukaryot Cell 4(5): 890-899.

Bermejo, C., Rodriguez, E., Garcia, R., Rodriguez-Pena, J. M., Rodriguez de la Concepcion, M. L., Rivas, C., Arias, P., Nombela, C., Posas, F. \& Arroyo, J. (2008). The sequential activation of the yeast HOG and SLT2 pathways is required for cell survival to cell wall stress. Mol Biol Cell 19(3): 1113-1124.

Bermejo, C., Garcia, R., Straede, A., Rodriguez-Pena, J. M., Nombela, C., Heinisch, J. J. \& Arroyo, J. (2010). Characterization of sensor-specific stress response by transcriptional profiling of wsc1 and mid2 deletion strains and chimeric sensors in Saccharomyces cerevisiae. OMICS 14(6): 679-688.

Bonilla, M. \& Cunningham, K. W. (2003). Mitogen-activated protein kinase stimulation of $\mathrm{Ca}(2+)$ signaling is required for survival of endoplasmic reticulum stress in yeast. Mol Biol Cell 14(10): 4296-4305.

Boone, C., Bussey, H. \& Andrews, B. J. (2007). Exploring genetic interactions and networks with yeast. Nat Rev Genet 8(6): 437-449. 


\section{Bibliografía}

Boysen, J. H. \& Mitchell, A. P. (2006). Control of Bro1-domain protein Rim20 localization by external $\mathrm{pH}$, ESCRT machinery, and the Saccharomyces cerevisiae Rim101 pathway. Mol Biol Cell 17(3): 1344-1353.

Bradford, M. M. (1976). A rapid and sensitive method for the quantitation of microgram quantities of protein utilizing the principle of protein-dye binding. Anal Biochem 72: 248-254.

Breeden, L. L. (2003). Periodic transcription: a cycle within a cycle. Curr Biol 13(1): R31-38.

Breitkreutz, A. \& Tyers, M. (2002). MAPK signaling specificity: it takes two to tango. Trends Cell Biol 12(6): 254-257.

Brown, S. S. (1997). Myosins in yeast. Curr Opin Cell Biol 9(1): 44-48.

Buehrer, B. M. \& Errede, B. (1997). Coordination of the mating and cell integrity mitogen-activated protein kinase pathways in Saccharomyces cerevisiae. Mol Cell Biol 17(11): 6517-6525.

Bulawa, C. E., Slater, M., Cabib, E., Au-Young, J., Sburlati, A., Adair, W. L., Jr. \& Robbins, P. W. (1986). The $S$. cerevisiae structural gene for chitin synthase is not required for chitin synthesis in vivo. Cell 46(2): 213-225.

Bulik, D. A., Olczak, M., Lucero, H. A., Osmond, B. C., Robbins, P. W. \& Specht, C. A. (2003). Chitin synthesis in Saccharomyces cerevisiae in response to supplementation of growth medium with glucosamine and cell wall stress. Eukaryot Cell 2(5): 886-900.

Cabib, E., Sburlati, A., Bowers, B. \& Silverman, S. J. (1989). Chitin synthase 1, an auxiliary enzyme for chitin synthesis in Saccharomyces cerevisiae. J Cell Biol 108(5): 1665-1672.

Cabib, E., Silverman, S. J. \& Shaw, J. A. (1992). Chitinase and chitin synthase 1: counterbalancing activities in cell separation of Saccharomyces cerevisiae. J Gen Microbiol 138(1): 97-102.

Cabib, E., Drgonova, J. \& Drgon, T. (1998). Role of small G proteins in yeast cell polarization and wall biosynthesis. Annu Rev Biochem 67: 307-333.

Cabib, E. \& Schmidt, M. (2003). Chitin synthase III activity, but not the chitin ring, is required for remedial septa formation in budding yeast. FEMS Microbiol Lett 224(2): 299-305.

Cabib, E. (2004). The septation apparatus, a chitin-requiring machine in budding yeast. Arch Biochem Biophys 426(2): 201-207.

Cabib, E. \& Duran, A. (2005). Synthase III-dependent chitin is bound to different acceptors depending on location on the cell wall of budding yeast. J Biol Chem 280(10): 9170-9179.

Cabib, E., Blanco, N., Grau, C., Rodriguez-Pena, J. M. \& Arroyo, J. (2007). Crh1p and Crh2p are required for the cross-linking of chitin to beta(1-6)glucan in the Saccharomyces cerevisiae cell wall. Mol Microbiol 63(3): 921-935.

Cabib, E., Farkas, V., Kosik, O., Blanco, N., Arroyo, J. \& McPhie, P. (2008). Assembly of the yeast cell wall. Crh1p and Crh2p act as transglycosylases in vivo and in vitro. J Biol Chem 283(44): 29859-29872.

Caviston, J. P., Longtine, M., Pringle, J. R. \& Bi, E. (2003). The role of Cdc42p GTPase-activating proteins in assembly of the septin ring in yeast. Mol Biol Cell 14(10): 4051-4066. 
Cid, V. J., Duran, A., del Rey, F., Snyder, M. P., Nombela, C. \& Sanchez, M. (1995). Molecular basis of cell integrity and morphogenesis in Saccharomyces cerevisiae. Microbiol Rev 59(3): 345-386.

Colman-Lerner, A., Chin, T. E. \& Brent, R. (2001). Yeast Cbk1 and Mob2 activate daughter-specific genetic programs to induce asymmetric cell fates. Cell 107(6): 739-750.

Cos, T., Ford, R. A., Trilla, J. A., Duran, A., Cabib, E. \& Roncero, C. (1998). Molecular analysis of Chs3p participation in chitin synthase III activity. Eur J Biochem 256(2): 419-426.

Chen, R. E. \& Thorner, J. (2007). Function and regulation in MAPK signaling pathways: lessons learned from the yeast Saccharomyces cerevisiae. Biochim Biophys Acta 1773(8): 13111340.

Choi, W. J. \& Cabib, E. (1994). The use of divalent cations and pH for the determination of specific yeast chitin synthetases. Anal Biochem 219(2): 368-372.

Christianson, T. W., Sikorski, R. S., Dante, M., Shero, J. H. \& Hieter, P. (1992). Multifunctional yeast high-copy-number shuttle vectors. Gene 110(1): 119-122.

Davenport, K. R., Sohaskey, M., Kamada, Y., Levin, D. E. \& Gustin, M. C. (1995). A second osmosensing signal transduction pathway in yeast. Hypotonic shock activates the PKC1 protein kinase-regulated cell integrity pathway. J Biol Chem 270(50): 30157-30161.

de Groot, P. W., Ruiz, C., Vazquez de Aldana, C. R., Duenas, E., Cid, V. J., Del Rey, F., Rodriquez-Pena, J. M., Perez, P., Andel, A., Caubin, J., Arroyo, J., Garcia, J. C., Gil, C., Molina, M., Garcia, L. J., Nombela, C. \& Klis, F. M. (2001). A genomic approach for the identification and classification of genes involved in cell wall formation and its regulation in Saccharomyces cerevisiae. Comp Funct Genomics 2(3): 124-142.

de Nobel, H., Ruiz, C., Martin, H., Morris, W., Brul, S., Molina, M. \& Klis, F. M. (2000). Cell wall perturbation in yeast results in dual phosphorylation of the Slt2/Mpk1 MAP kinase and in an SIt2-mediated increase in FKS2-lacZ expression, glucanase resistance and thermotolerance. Microbiology 146 ( Pt 9): 2121-2132.

Dekker, C., Stirling, P. C., McCormack, E. A., Filmore, H., Paul, A., Brost, R. L., Costanzo, M., Boone, C., Leroux, M. R. \& Willison, K. R. (2008). The interaction network of the chaperonin CCT. EMBO J 27(13): 1827-1839.

Delley, P. A. \& Hall, M. N. (1999). Cell wall stress depolarizes cell growth via hyperactivation of RHO1. J Cell Biol 147(1): 163-174.

DeMarini, D. J., Adams, A. E., Fares, H., De Virgilio, C., Valle, G., Chuang, J. S. \& Pringle, J. R. (1997). A septin-based hierarchy of proteins required for localized deposition of chitin in the Saccharomyces cerevisiae cell wall. J Cell Biol 139(1): 75-93.

Denis, V. \& Cyert, M. S. (2005). Molecular analysis reveals localization of Saccharomyces cerevisiae protein kinase $\mathrm{C}$ to sites of polarized growth and Pkc1p targeting to the nucleus and mitotic spindle. Eukaryot Cell 4(1): 36-45.

Dobbelaere, J. \& Barral, Y. (2004). Spatial coordination of cytokinetic events by compartmentalization of the cell cortex. Science 305(5682): 393-396. 


\section{Bibliografía}

Dodou, E. \& Treisman, R. (1997). The Saccharomyces cerevisiae MADS-box transcription factor RIm1 is a target for the Mpk1 mitogen-activated protein kinase pathway. Mol Cell Biol 17(4): 1848-1859.

Dohrmann, P. R., Butler, G., Tamai, K., Dorland, S., Greene, J. R., Thiele, D. J. \& Stillman, D. J. (1992). Parallel pathways of gene regulation: homologous regulators SWI5 and ACE2 differentially control transcription of $H O$ and chitinase. Genes Dev 6(1): 93-104.

Doi, K., Gartner, A., Ammerer, G., Errede, B., Shinkawa, H., Sugimoto, K. \& Matsumoto, K. (1994). MSG5, a novel protein phosphatase promotes adaptation to pheromone response in $S$. cerevisiae. EMBO J 13(1): 61-70.

Errede, B., Cade, R. M., Yashar, B. M., Kamada, Y., Levin, D. E., Irie, K. \& Matsumoto, K. (1995). Dynamics and organization of MAP kinase signal pathways. Mol Reprod Dev 42(4): 477-485.

Flandez, M., Cosano, I. C., Nombela, C., Martin, H. \& Molina, M. (2004). Reciprocal regulation between SIt2 MAPK and isoforms of Msg5 dual-specificity protein phosphatase modulates the yeast cell integrity pathway. J Biol Chem 279(12): 11027-11034.

Futai, E., Maeda, T., Sorimachi, H., Kitamoto, K., Ishiura, S. \& Suzuki, K. (1999). The protease activity of a calpain-like cysteine protease in Saccharomyces cerevisiae is required for alkaline adaptation and sporulation. Mol Gen Genet 260(6): 559-568.

Garcia-Rodriguez, L. J., Duran, A. \& Roncero, C. (2000). Calcofluor antifungal action depends on chitin and a functional high-osmolarity glycerol response (HOG) pathway: evidence for a physiological role of the Saccharomyces cerevisiae HOG pathway under noninducing conditions. J Bacteriol 182(9): 2428-2437.

Garcia-Rodriguez, L. J., Valle, R., Duran, A. \& Roncero, C. (2005). Cell integrity signaling activation in response to hyperosmotic shock in yeast. FEBS Lett 579(27): 6186-6190.

Garcia, R., Bermejo, C., Grau, C., Perez, R., Rodriguez-Pena, J. M., Francois, J., Nombela, C. \& Arroyo, J. (2004). The global transcriptional response to transient cell wall damage in Saccharomyces cerevisiae and its regulation by the cell integrity signaling pathway. $J$ Biol Chem 279(15): 15183-15195.

Garcia, R., Rodriguez-Pena, J. M., Bermejo, C., Nombela, C. \& Arroyo, J. (2009). The high osmotic response and cell wall integrity pathways cooperate to regulate transcriptional responses to zymolyase-induced cell wall stress in Saccharomyces cerevisiae. J Biol Chem 284(16): 1090110911.

Gladfelter, A. S., Kozubowski, L., Zyla, T. R. \& Lew, D. J. (2005). Interplay between septin organization, cell cycle and cell shape in yeast. J Cell Sci 118(Pt 8): 1617-1628.

Goldstein, A. L. \& McCusker, J. H. (1999). Three new dominant drug resistance cassettes for gene disruption in Saccharomyces cerevisiae. Yeast 15(14): 1541-1553.

Gonzalez, A., Larroy, C., Biosca, J. A. \& Arino, J. (2008). Use of the TRP1 auxotrophic marker for gene disruption and phenotypic analysis in yeast: a note of warning. FEMS Yeast Res 8(1): 2-5.

Grabinska, K. A., Magnelli, P. \& Robbins, P. W. (2007). Prenylation of Saccharomyces cerevisiae Chs4p affects Chitin Synthase III activity and chitin chain length. Eukaryot Cell 6(2): 328-336. 
Harrison, J. C., Bardes, E. S., Ohya, Y. \& Lew, D. J. (2001). A role for the Pkc1p/Mpk1p kinase cascade in the morphogenesis checkpoint. Nat Cell Biol 3(4): 417-420.

Hayashi, M., Fukuzawa, T., Sorimachi, H. \& Maeda, T. (2005). Constitutive activation of the pHresponsive Rim101 pathway in yeast mutants defective in late steps of the MVB/ESCRT pathway. Mol Cell Biol 25(21): 9478-9490.

Heinisch, J. J., Dupres, V., Wilk, S., Jendretzki, A. \& Dufrene, Y. F. (2010). Single-molecule atomic force microscopy reveals clustering of the yeast plasma-membrane sensor Wsc1. PLoS One 5(6): e11104.

Herrador, A., Herranz, S., Lara, D. \& Vincent, O. (2010). Recruitment of the ESCRT machinery to a putative seven-transmembrane-domain receptor is mediated by an arrestin-related protein. Mol Cell Biol 30(4): 897-907.

Hill, J. E., Myers, A. M., Koerner, T. J. \& Tzagoloff, A. (1986). Yeast/E. coli shuttle vectors with multiple unique restriction sites. Yeast 2(3): 163-167.

Hruby, A., Zapatka, M., Heucke, S., Rieger, L., Wu, Y., Nussbaumer, U., Timmermann, S., Dunkler, A. \& Johnsson, N. (2011). A constraint network of interactions: protein-protein interaction analysis of the yeast type II phosphatase Ptc1p and its adaptor protein Nbp2p. J Cell Sci 124(Pt 1): 35-46.

Igual, J. C., Johnson, A. L. \& Johnston, L. H. (1996). Coordinated regulation of gene expression by the cell cycle transcription factor Swi4 and the protein kinase C MAP kinase pathway for yeast cell integrity. EMBO J 15(18): 5001-5013.

Ikeda, M., Kihara, A., Denpoh, A. \& Igarashi, Y. (2008). The Rim101 pathway is involved in Rsb1 expression induced by altered lipid asymmetry. Mol Biol Cell 19(5): 1922-1931.

Irie, K., Takase, M., Lee, K. S., Levin, D. E., Araki, H., Matsumoto, K. \& Oshima, Y. (1993). MKK1 and MKK2, which encode Saccharomyces cerevisiae mitogen-activated protein kinase-kinase homologs, function in the pathway mediated by protein kinase C. Mol Cell Biol 13(5): 30763083.

Ishihara, S., Hirata, A., Nogami, S., Beauvais, A., Latge, J. P. \& Ohya, Y. (2007). Homologous subunits of 1,3-beta-glucan synthase are important for spore wall assembly in Saccharomyces cerevisiae. Eukaryot Cell 6(2): 143-156.

Jung, U. S., Sobering, A. K., Romeo, M. J. \& Levin, D. E. (2002). Regulation of the yeast R/m1 transcription factor by the Mpk1 cell wall integrity MAP kinase. Mol Microbiol 46(3): 781789.

Kabir, M. A., Kaminska, J., Segel, G. B., Bethlendy, G., Lin, P., Della Seta, F., Blegen, C., Swiderek, K. M., Zoladek, T., Arndt, K. T. \& Sherman, F. (2005). Physiological effects of unassembled chaperonin Cct subunits in the yeast Saccharomyces cerevisiae. Yeast 22(3): 219-239.

Kamada, Y., Jung, U. S., Piotrowski, J. \& Levin, D. E. (1995). The protein kinase C-activated MAP kinase pathway of Saccharomyces cerevisiae mediates a novel aspect of the heat shock response. Genes Dev 9(13): 1559-1571.

Kamada, Y., Qadota, H., Python, C. P., Anraku, Y., Ohya, Y. \& Levin, D. E. (1996). Activation of yeast protein kinase C by Rho1 GTPase. J Biol Chem 271(16): 9193-9196. 
Ketela, T., Green, R. \& Bussey, H. (1999). Saccharomyces cerevisiae mid2p is a potential cell wall stress sensor and upstream activator of the PKC1-MPK1 cell integrity pathway. $J$ Bacteriol 181(11): 3330-3340.

Klis, F. M., Mol, P., Hellingwerf, K. \& Brul, S. (2002). Dynamics of cell wall structure in Saccharomyces cerevisiae. FEMS Microbiol Rev 26(3): 239-256.

Klis, F. M., Boorsma, A. \& De Groot, P. W. (2006). Cell wall construction in Saccharomyces cerevisiae. Yeast 23(3): 185-202.

Koh, J. L., Ding, H., Costanzo, M., Baryshnikova, A., Toufighi, K., Bader, G. D., Myers, C. L., Andrews, B. J. \& Boone, C. (2010). DRYGIN: a database of quantitative genetic interaction networks in yeast. Nucleic Acids Res 38(Database issue): D502-507.

Kollar, R., Petrakova, E., Ashwell, G., Robbins, P. W. \& Cabib, E. (1995). Architecture of the yeast cell wall. The linkage between chitin and beta(1-->3)-glucan. J Biol Chem 270(3): 1170-1178.

Kollar, R., Reinhold, B. B., Petrakova, E., Yeh, H. J., Ashwell, G., Drgonova, J., Kapteyn, J. C., Klis, F. M. \& Cabib, E. (1997). Architecture of the yeast cell wall. Beta(1-->6)-glucan interconnects mannoprotein, beta(1-->)3-glucan, and chitin. J Biol Chem 272(28): 17762-17775.

Kota, J. \& Ljungdahl, P. O. (2005). Specialized membrane-localized chaperones prevent aggregation of polytopic proteins in the ER. J Cell Biol 168(1): 79-88.

Kozubowski, L., Panek, H., Rosenthal, A., Bloecher, A., DeMarini, D. J. \& Tatchell, K. (2003). A Bni4Glc7 phosphatase complex that recruits chitin synthase to the site of bud emergence. Mol Biol Cell 14(1): 26-39.

Kozubowski, L., Larson, J. R. \& Tatchell, K. (2005). Role of the septin ring in the asymmetric localization of proteins at the mother-bud neck in Saccharomyces cerevisiae. Mol Biol Cell 16(8): 3455-3466.

Krause, S. A. \& Gray, J. V. (2002). The protein kinase C pathway is required for viability in quiescence in Saccharomyces cerevisiae. Curr Biol 12(7): 588-593.

Kuranda, M. J. \& Robbins, P. W. (1991). Chitinase is required for cell separation during growth of Saccharomyces cerevisiae. J Biol Chem 266(29): 19758-19767.

Kushner, S. R. (1978). An improved method for transformation of Escherichia coli with ColE1 derived plasmids. In Genetic engineering (eds H. W. Boyer and S. Nicosia). Amsterdam: Elsevier/North-Holland Biomedical Press.: 17-23.

Laemmli, U. K. (1970). Cleavage of structural proteins during the assembly of the head of bacteriophage T4. Nature 227(5259): 680-685.

Lagorce, A., Le Berre-Anton, V., Aguilar-Uscanga, B., Martin-Yken, H., Dagkessamanskaia, A. \& Francois, J. (2002). Involvement of GFA1, which encodes glutamine-fructose-6-phosphate amidotransferase, in the activation of the chitin synthesis pathway in response to cell-wall defects in Saccharomyces cerevisiae. Eur J Biochem 269(6): 1697-1707.

Lagorce, A., Hauser, N. C., Labourdette, D., Rodriguez, C., Martin-Yken, H., Arroyo, J., Hoheisel, J. D. \& Francois, J. (2003). Genome-wide analysis of the response to cell wall mutations in the yeast Saccharomyces cerevisiae. J Biol Chem 278(22): 20345-20357. 
Lam, K. K., Davey, M., Sun, B., Roth, A. F., Davis, N. G. \& Conibear, E. (2006). Palmitoylation by the DHHC protein Pfa4 regulates the ER exit of Chs3. J Cell Biol 174(1): 19-25.

Lamb, T. M., Xu, W., Diamond, A. \& Mitchell, A. P. (2001). Alkaline response genes of Saccharomyces cerevisiae and their relationship to the RIM101 pathway. J Biol Chem 276(3): 1850-1856.

Lamb, T. M. \& Mitchell, A. P. (2003). The transcription factor Rim101p governs ion tolerance and cell differentiation by direct repression of the regulatory genes NRG1 and SMP1 in Saccharomyces cerevisiae. Mol Cell Biol 23(2): 677-686.

Larson, J. R., Bharucha, J. P., Ceaser, S., Salamon, J., Richardson, C. J., Rivera, S. M. \& Tatchell, K. (2008). Protein phosphatase type 1 directs chitin synthesis at the bud neck in Saccharomyces cerevisiae. Mol Biol Cell 19(7): 3040-3051.

Lee, K. S. \& Levin, D. E. (1992). Dominant mutations in a gene encoding a putative protein kinase $(B C K 1)$ bypass the requirement for a Saccharomyces cerevisiae protein kinase $\mathrm{C}$ homolog. Mol Cell Biol 12(1): 172-182.

Lesage, G., Shapiro, J., Specht, C. A., Sdicu, A. M., Menard, P., Hussein, S., Tong, A. H., Boone, C. \& Bussey, H. (2005). An interactional network of genes involved in chitin synthesis in Saccharomyces cerevisiae. BMC Genet 6: 8.

Lesage, G. \& Bussey, H. (2006). Cell wall assembly in Saccharomyces cerevisiae. Microbiol Mol Biol $\operatorname{Rev} 70(2): 317-343$.

Levin, D. E. (2005). Cell wall integrity signaling in Saccharomyces cerevisiae. Microbiol Mol Biol Rev 69(2): 262-291.

Li, S., Dean, S., Li, Z., Horecka, J., Deschenes, R. J. \& Fassler, J. S. (2002). The eukaryotic twocomponent histidine kinase $\operatorname{SIn} 1 \mathrm{p}$ regulates $\mathrm{OCH} 1$ via the transcription factor, $5 \mathrm{kn} 7 \mathrm{p}$. Mol Biol Cell 13(2): 412-424.

Li, W. \& Mitchell, A. P. (1997). Proteolytic activation of Rim1p, a positive regulator of yeast sporulation and invasive growth. Genetics 145(1): 63-73.

Lin, Y., Kimpler, L. A., Naismith, T. V., Lauer, J. M. \& Hanson, P. I. (2005). Interaction of the mammalian endosomal sorting complex required for transport (ESCRT) III protein hSnf7-1 with itself, membranes, and the AAA+ ATPase SKD1. J Biol Chem 280(13): 12799-12809.

Lipke, P. N. \& Kurjan, J. (1992). Sexual agglutination in budding yeasts: structure, function, and regulation of adhesion glycoproteins. Microbiol Rev 56(1): 180-194.

Lippincott, J. \& Li, R. (1998). Sequential assembly of myosin II, an IQGAP-like protein, and filamentous actin to a ring structure involved in budding yeast cytokinesis. J Cell Biol 140(2): 355-366.

Locke, E. G., Bonilla, M., Liang, L., Takita, Y. \& Cunningham, K. W. (2000). A homolog of voltage-gated $\mathrm{Ca}(2+)$ channels stimulated by depletion of secretory $\mathrm{Ca}(2+)$ in yeast. Mol Cell Biol 20(18): 6686-6694.

Longtine, M. S., DeMarini, D. J., Valencik, M. L., Al-Awar, O. S., Fares, H., De Virgilio, C. \& Pringle, J. R. (1996). The septins: roles in cytokinesis and other processes. Curr Opin Cell Biol 8(1): 106119. 


\section{Bibliografía}

Madden, K., Sheu, Y. J., Baetz, K., Andrews, B. \& Snyder, M. (1997). SBF cell cycle regulator as a target of the yeast PKC-MAP kinase pathway. Science 275(5307): 1781-1784.

Marini, N. J., Meldrum, E., Buehrer, B., Hubberstey, A. V., Stone, D. E., Traynor-Kaplan, A. \& Reed, S. I. (1996). A pathway in the yeast cell division cycle linking protein kinase C (Pkc1) to activation of Cdc28 at START. EMBO J 15(12): 3040-3052.

Mattison, C. P., Spencer, S. S., Kresge, K. A., Lee, J. \& Ota, I. M. (1999). Differential regulation of the cell wall integrity mitogen-activated protein kinase pathway in budding yeast by the protein tyrosine phosphatases Ptp2 and Ptp3. Mol Cell Biol 19(11): 7651-7660.

Mazur, P., Morin, N., Baginsky, W., el-Sherbeini, M., Clemas, J. A., Nielsen, J. B. \& Foor, F. (1995). Differential expression and function of two homologous subunits of yeast 1,3-beta-D-glucan synthase. Mol Cell Biol 15(10): 5671-5681.

Mazzoni, C., Zarov, P., Rambourg, A. \& Mann, C. (1993). The SLT2 (MPK1) MAP kinase homolog is involved in polarized cell growth in Saccharomyces cerevisiae. J Cell Biol 123(6 Pt 2): 18211833.

Merchan, S., Bernal, D., Serrano, R. \& Yenush, L. (2004). Response of the Saccharomyces cerevisiae Mpk1 mitogen-activated protein kinase pathway to increases in internal turgor pressure caused by loss of Ppz protein phosphatases. Eukaryot Cell 3(1): 100-107.

Mira, N. P., Lourenco, A. B., Fernandes, A. R., Becker, J. D. \& Sa-Correia, I. (2009). The RIM101 pathway has a role in Saccharomyces cerevisiae adaptive response and resistance to propionic acid and other weak acids. FEMS Yeast Res 9(2): 202-216.

Moehle, C. M., Tizard, R., Lemmon, S. K., Smart, J. \& Jones, E. W. (1987). Protease B of the lysosomelike vacuole of the yeast Saccharomyces cerevisiae is homologous to the subtilisin family of serine proteases. Mol Cell Biol 7(12): 4390-4399.

Moseley, J. B. \& Goode, B. L. (2006). The yeast actin cytoskeleton: from cellular function to biochemical mechanism. Microbiol Mol Biol Rev 70(3): 605-645.

Mouyna, I., Fontaine, T., Vai, M., Monod, M., Fonzi, W. A., Diaquin, M., Popolo, L., Hartland, R. P. \& Latge, J. P. (2000). Glycosylphosphatidylinositol-anchored glucanosyltransferases play an active role in the biosynthesis of the fungal cell wall. J Biol Chem 275(20): 14882-14889.

Neves, M. J. \& Francois, J. (1992). On the mechanism by which a heat shock induces trehalose accumulation in Saccharomyces cerevisiae. Biochem J 288 ( Pt 3): 859-864.

Nonaka, H., Tanaka, K., Hirano, H., Fujiwara, T., Kohno, H., Umikawa, M., Mino, A. \& Takai, Y. (1995). A downstream target of RHO1 small GTP-binding protein is PKC1, a homolog of protein kinase $C$, which leads to activation of the MAP kinase cascade in Saccharomyces cerevisiae. EMBO J 14(23): 5931-5938.

Odds, F. C., Brown, A. J. \& Gow, N. A. (2003). Antifungal agents: mechanisms of action. Trends Microbiol 11(6): 272-279.

Osumi, M. (1998). The ultrastructure of yeast: cell wall structure and formation. Micron 29(2-3): 207233. 
Palecek, S. P., Parikh, A. S. \& Kron, S. J. (2002). Sensing, signalling and integrating physical processes during Saccharomyces cerevisiae invasive and filamentous growth. Microbiology 148(Pt 4): 893-907.

Paravicini, G., Cooper, M., Friedli, L., Smith, D. J., Carpentier, J. L., Klig, L. S. \& Payton, M. A. (1992). The osmotic integrity of the yeast cell requires a functional PKC1 gene product. Mol Cell Biol 12(11): 4896-4905.

Paravicini, G. \& Friedli, L. (1996). Protein-protein interactions in the yeast PKC1 pathway: Pkc1p interacts with a component of the MAP kinase cascade. Mol Gen Genet 251(6): 682-691.

Parnell, E. J. \& Stillman, D. J. (2008). Getting a transcription factor to only one nucleus following mitosis. PLoS Biol 6(9): e229.

Parsons, A. B., Brost, R. L., Ding, H., Li, Z., Zhang, C., Sheikh, B., Brown, G. W., Kane, P. M., Hughes, T. R. \& Boone, C. (2004). Integration of chemical-genetic and genetic interaction data links bioactive compounds to cellular target pathways. Nat Biotechnol 22(1): 62-69.

Penalva, M. A. \& Arst, H. N., Jr. (2004). Recent advances in the characterization of ambient pH regulation of gene expression in filamentous fungi and yeasts. Annu Rev Microbiol 58: 425451.

Penalva, M. A., Tilburn, J., Bignell, E. \& Arst, H. N., Jr. (2008). Ambient pH gene regulation in fungi: making connections. Trends Microbiol 16(6): 291-300.

Petkova, M. I., Pujol-Carrion, N., Arroyo, J., Garcia-Cantalejo, J. \& Angeles de la Torre-Ruiz, M. (2010). $\mathrm{Mtl} 1$ is required to activate general stress response through Tor1 and Ras2 inhibition under conditions of glucose starvation and oxidative stress. J Biol Chem 285(25): 19521-19531.

Popolo, L., Gualtieri, T. \& Ragni, E. (2001). The yeast cell-wall salvage pathway. Med Mycol 39 Suppl 1: 111-121.

Rajavel, M., Philip, B., Buehrer, B. M., Errede, B. \& Levin, D. E. (1999). Mid2 is a putative sensor for cell integrity signaling in Saccharomyces cerevisiae. Mol Cell Biol 19(6): 3969-3976.

Reinoso-Martin, C., Schuller, C., Schuetzer-Muehlbauer, M. \& Kuchler, K. (2003). The yeast protein kinase $C$ cell integrity pathway mediates tolerance to the antifungal drug caspofungin through activation of SIt2p mitogen-activated protein kinase signaling. Eukaryot Cell 2(6): 1200-1210.

Reissig, J. L., Storminger, J. L. \& Leloir, L. F. (1955). A modified colorimetric method for the estimation of N-acetylamino sugars. J Biol Chem 217(2): 959-966.

Reyes, A., Sanz, M., Duran, A. \& Roncero, C. (2007). Chitin synthase III requires Chs4p-dependent translocation of Chs3p into the plasma membrane. J Cell Sci 120(Pt 12): 1998-2009.

Roemer, T., Vallier, L., Sheu, Y. J. \& Snyder, M. (1998). The Spa2-related protein, Sph1p, is important for polarized growth in yeast. J Cell Sci 111 ( Pt 4): 479-494.

Rolli, E., Ragni, E., Calderon, J., Porello, S., Fascio, U. \& Popolo, L. (2009). Immobilization of the glycosylphosphatidylinositol-anchored Gas1 protein into the chitin ring and septum is required for proper morphogenesis in yeast. Mol Biol Cell 20(22): 4856-4870. 
Roncero, C. \& Duran, A. (1985). Effect of Calcofluor white and Congo red on fungal cell wall morphogenesis: in vivo activation of chitin polymerization. J Bacteriol 163(3): 1180-1185.

Roncero, C. (2002). The genetic complexity of chitin synthesis in fungi. Curr Genet 41(6): 367-378.

Roncero, C. \& Sanchez, Y. (2010). Cell separation and the maintenance of cell integrity during cytokinesis in yeast: the assembly of a septum. Yeast 27(8): 521-530.

Rothstein, R. J. (1983). One-step gene disruption in yeast. Methods Enzymol 101: 202-211.

Sambrook, J., Fritsch, E. F. \& Manniatis, T. (1989). Molecular Cloning: a laboratory manual (eds J. Sambrook and T. Manniatis). Cold Spring Harbor, NY: Cold Spring Harbor Laboratory Press.

Sambrook, J. \& Russell, D. W. (2001). Molecular cloning, a laboratory manual. Cold Spring Harbor Laboratory Press, Cold Spring Harbor, New York.

Sanger, F., Nicklen, S. \& Coulson, A. R. (1977). DNA sequencing with chain-terminating inhibitors. Proc Natl Acad Sci U S A 74(12): 5463-5467.

Santos, B., Duran, A. \& Valdivieso, M. H. (1997). CHS5, a gene involved in chitin synthesis and mating in Saccharomyces cerevisiae. Mol Cell Biol 17(5): 2485-2496.

Sanz, M., Trilla, J. A., Duran, A. \& Roncero, C. (2002). Control of chitin synthesis through Shc1p, a functional homologue of Chs4p specifically induced during sporulation. Mol Microbiol 43(5): 1183-1195.

Sanz, M., Castrejon, F., Duran, A. \& Roncero, C. (2004). Saccharomyces cerevisiae Bni4p directs the formation of the chitin ring and also participates in the correct assembly of the septum structure. Microbiology 150(Pt 10): 3229-3241.

Schmidt, M., Bowers, B., Varma, A., Roh, D. H. \& Cabib, E. (2002). In budding yeast, contraction of the actomyosin ring and formation of the primary septum at cytokinesis depend on each other. J Cell Sci 115(Pt 2): 293-302.

Schmidt, M., Varma, A., Drgon, T., Bowers, B. \& Cabib, E. (2003). Septins, under Cla4p regulation, and the chitin ring are required for neck integrity in budding yeast. Mol Biol Cell 14(5): 21282141.

Serrano, R., Ruiz, A., Bernal, D., Chambers, J. R. \& Arino, J. (2002). The transcriptional response to alkaline $\mathrm{pH}$ in Saccharomyces cerevisiae: evidence for calcium-mediated signalling. Mol Microbiol 46(5): 1319-1333.

Serrano, R., Martin, H., Casamayor, A. \& Arino, J. (2006). Signaling alkaline pH stress in the yeast Saccharomyces cerevisiae through the Wsc1 cell surface sensor and the Slt2 MAPK pathway. J Biol Chem 281(52): 39785-39795.

Shahinian, S. \& Bussey, H. (2000). beta-1,6-Glucan synthesis in Saccharomyces cerevisiae. Mol Microbiol 35(3): 477-489.

Shaw, J. A., Mol, P. C., Bowers, B., Silverman, S. J., Valdivieso, M. H., Duran, A. \& Cabib, E. (1991). The function of chitin synthases 2 and 3 in the Saccharomyces cerevisiae cell cycle. $J$ Cell Biol 114(1): 111-123. 
Sheu, Y. J., Santos, B., Fortin, N., Costigan, C. \& Snyder, M. (1998). Spa2p interacts with cell polarity proteins and signaling components involved in yeast cell morphogenesis. Mol Cell Biol 18(7): 4053-4069.

Sia, R. A., Herald, H. A. \& Lew, D. J. (1996). Cdc28 tyrosine phosphorylation and the morphogenesis checkpoint in budding yeast. Mol Biol Cell 7(11): 1657-1666.

Sikorski, R. S. \& Hieter, P. (1989). A system of shuttle vectors and yeast host strains designed for efficient manipulation of DNA in Saccharomyces cerevisiae. Genetics 122(1): 19-27.

Silverman, S. J., Sburlati, A., Slater, M. L. \& Cabib, E. (1988). Chitin synthase 2 is essential for septum formation and cell division in Saccharomyces cerevisiae. Proc Natl Acad Sci U S A 85(13): 4735-4739.

Smits, G. J., van den Ende, H. \& Klis, F. M. (2001). Differential regulation of cell wall biogenesis during growth and development in yeast. Microbiology 147(Pt 4): 781-794.

Stoldt, V., Rademacher, F., Kehren, V., Ernst, J. F., Pearce, D. A. \& Sherman, F. (1996). Review: the Cct eukaryotic chaperonin subunits of Saccharomyces cerevisiae and other yeasts. Yeast 12(6): 523-529.

Su, S. S. \& Mitchell, A. P. (1993). Molecular characterization of the yeast meiotic regulatory gene RIM1. Nucleic Acids Res 21(16): 3789-3797.

Teh, E. M., Chai, C. C. \& Yeong, F. M. (2009). Retention of Chs2p in the ER requires N-terminal CDK1phosphorylation sites. Cell Cycle 8(18): 2964-2974.

Teo, H., Gill, D. J., Sun, J., Perisic, O., Veprintsev, D. B., Vallis, Y., Emr, S. D. \& Williams, R. L. (2006). ESCRT-I core and ESCRT-II GLUE domain structures reveal role for GLUE in linking to ESCRT-I and membranes. Cell 125(1): 99-111.

Tong, A. H., Lesage, G., Bader, G. D., Ding, H., Xu, H., Xin, X., Young, J., Berriz, G. F., Brost, R. L., Chang, M., Chen, Y., Cheng, X., Chua, G., Friesen, H., Goldberg, D. S., Haynes, J., Humphries, C., He, G., Hussein, S., Ke, L., Krogan, N., Li, Z., Levinson, J. N., Lu, H., Menard, P., Munyana, C., Parsons, A. B., Ryan, O., Tonikian, R., Roberts, T., Sdicu, A. M., Shapiro, J., Sheikh, B., Suter, B., Wong, S. L., Zhang, L. V., Zhu, H., Burd, C. G., Munro, S., Sander, C., Rine, J., Greenblatt, J., Peter, M., Bretscher, A., Bell, G., Roth, F. P., Brown, G. W., Andrews, B., Bussey, H. \& Boone, C. (2004). Global mapping of the yeast genetic interaction network. Science 303(5659): 808-813.

Torres, J., Di Como, C. J., Herrero, E. \& De La Torre-Ruiz, M. A. (2002). Regulation of the cell integrity pathway by rapamycin-sensitive TOR function in budding yeast. J Biol Chem 277(45): 4349543504.

Torres, L., Martin, H., Garcia-Saez, M. I., Arroyo, J., Molina, M., Sanchez, M. \& Nombela, C. (1991). A protein kinase gene complements the lytic phenotype of Saccharomyces cerevisiae lyt2 mutants. Mol Microbiol 5(11): 2845-2854.

Trautwein, M., Schindler, C., Gauss, R., Dengjel, J., Hartmann, E. \& Spang, A. (2006). Arf1p, Chs5p and the ChAPs are required for export of specialized cargo from the Golgi. EMBO J 25(5): 943954. 


\section{Bibliografía}

Trilla, J. A., Cos, T., Duran, A. \& Roncero, C. (1997). Characterization of CHS4 (CAL2), a gene of Saccharomyces cerevisiae involved in chitin biosynthesis and allelic to SKT5 and CSD4. Yeast 13(9): 795-807.

Trilla, J. A., Duran, A. \& Roncero, C. (1999). Chs7p, a new protein involved in the control of protein export from the endoplasmic reticulum that is specifically engaged in the regulation of chitin synthesis in Saccharomyces cerevisiae. J Cell Biol 145(6): 1153-1163.

Valdivieso, M. H., Mol, P. C., Shaw, J. A., Cabib, E. \& Duran, A. (1991). CAL1, a gene required for activity of chitin synthase 3 in Saccharomyces cerevisiae. J Cell Biol 114(1): 101-109.

Valdivieso, M. H., Duran, A. \& Roncero, C. (2004). Chitin biosynthesis and morphogenetic processes. In The Mycota vol III. Biochemistry and Molecular Biology, 2nd Edition, (eds R. Brambl and G. A. Marzluf): 275-290 Berlin-Heidelberg: Springer-Verlag

van Drogen, F. \& Peter, M. (2002). Spa2p functions as a scaffold-like protein to recruit the Mpk1p MAP kinase module to sites of polarized growth. Curr Biol 12(19): 1698-1703.

Verna, J., Lodder, A., Lee, K., Vagts, A. \& Ballester, R. (1997). A family of genes required for maintenance of cell wall integrity and for the stress response in Saccharomyces cerevisiae. Proc Natl Acad Sci U S A 94(25): 13804-13809.

Vincent, O., Rainbow, L., Tilburn, J., Arst, H. N., Jr. \& Penalva, M. A. (2003). YPXL/I is a protein interaction motif recognized by aspergillus PalA and its human homologue, AIP1/Alix. Mol Cell Biol 23(5): 1647-1655.

Watanabe, Y., Takaesu, G., Hagiwara, M., Irie, K. \& Matsumoto, K. (1997). Characterization of a serum response factor-like protein in Saccharomyces cerevisiae, RIm1, which has transcriptional activity regulated by the Mpk1 (SIt2) mitogen-activated protein kinase pathway. Mol Cell Biol 17(5): 2615-2623.

Withee, J. L., Mulholland, J., Jeng, R. \& Cyert, M. S. (1997). An essential role of the yeast pheromoneinduced Ca2+ signal is to activate calcineurin. Mol Biol Cell 8(2): 263-277.

Xu, W. \& Mitchell, A. P. (2001). Yeast PalA/AIP1/Alix homolog Rim20p associates with a PEST-like region and is required for its proteolytic cleavage. J Bacteriol 183(23): 6917-6923.

Xu, W., Smith, F. J., Jr., Subaran, R. \& Mitchell, A. P. (2004). Multivesicular body-ESCRT components function in $\mathrm{pH}$ response regulation in Saccharomyces cerevisiae and Candida albicans. Mol Biol Cell 15(12): 5528-5537.

Zarzov, P., Mazzoni, C. \& Mann, C. (1996). The SLT2(MPK1) MAP kinase is activated during periods of polarized cell growth in yeast. EMBO J 15(1): 83-91.

Zhou, C., Yang, Y. \& Jong, A. Y. (1990). Mini-prep in ten minutes. Biotechniques 8(2): 172-173.

Zou, J., Friesen, H., Larson, J., Huang, D., Cox, M., Tatchell, K. \& Andrews, B. (2009). Regulation of cell polarity through phosphorylation of Bni4 by Pho85 G1 cyclin-dependent kinases in Saccharomyces cerevisiae. Mol Biol Cell 20(14): 3239-3250. 